TATIANA DE OLIVEIRA ONOZATO

\title{
O espaço da criança na Aldeia de Carapicuíba
}

São Paulo

2009 
20 ESPAÇO DA CRIANÇA NA ALDEIA DE CARAPICUIBA 
TATIANA DE OLIVEIRA ONOZATO

\section{O espaço da criança na Aldeia de Carapicuíba}

DISSERTAÇÃO APRESENTADA À FACULDADE DE ARQUITETURA E URBANISMO

DA UNIVERSIDADE DE SÃO PAULO PARA OBTENÇÃO DO TÍTULO DE MESTRE EM ARQUITETURA E URBANISMO ÁREA DE CONCENTRAÇÃO: PROJETO DE ARQUITETURA

ORIENTADOR: PROFO DR ${ }^{\circ}$ SYLVIO BARROS SAWAYA

São Paulo 2009 
AUTORIZO A REPRODUÇÃO E DIVULGAÇÃO TOTAL OU PARCIAL DESTE TRABALHO, POR QUALQUER MEIO CONVENCIONAL OU ELETRÔNICO, PARA FINS DE ESTUDO E PESQUISA, DESDE QUE CITADA A FONTE.

E-MAIL:tationozato@yahoo.com.br

\begin{tabular}{l} 
Onozato, Tatiana de Oliveira \\
0 espaço da criança na Aldeia de Carapicuíba / \\
Tatiana de Oliveira Onozato. --São Paulo, 2009. \\
307 p. : il. \\
Dissertação (Mestrado - Área de Concentração: Projeto \\
de Arquitetura) - FAUUSP. \\
Orientador: Sylvio Barros Sawaya \\
1. Arquitetura 2.Espaços culturais 3.Brincadeiras \\
4.Aldeia de Carapicuíba (SP) I.Título \\
CDU 72 \\
\hline
\end{tabular}


Às crianças da OCA e Aos meus sobrinhos Sofia e Lucas 


\section{AGRADECIMENTOS}

Infinita gratidão a Deus que colocou em meu caminho todas as pessoas com as quais compartilhei e compartilho minha vida.

Ao meu melhor amigo e eterno amor, Maurício, pelo carinho, apoio, compreensão e paciência. Pelo incentivo, no dia-a-dia, a acreditar em meus sonhos e comungar a esperança de mundo melhor.

Ao Prof. Dr. Sylvio Barros Sawaya, mestre e amigo de grande coração e sensibilidade; por ter enxergado uma força em mim que eu nem imaginava que existia.

As professoras da banca de qualificação: Prof. Dra Anália Amorim e Prof Dra Clice Sanjar Mazzilli pelas sábias colocações que nortearam a finalização desta dissertação.

Aos professores: Prof. Dr Eduardo de Jesus Rodrigues, Prof. Dra Maria José Feitosa e Prof. Dr Miguel Pereira, pelas conversas esclarecedoras e pelo apoio.

Ao Prof. Dr. Alexandre Delijaicov por conduzir sabiamente a minha primeira experiência didática e por ampliar o meu conceito de arquitetura $e$ compreensão do verdadeiro papel do arquiteto. 
Aos funcionários da FAU Maranhão e FAU Cidade Universitária, sem a energia de vocês nada funcionaria. Em especial, à Isa, Estelita e Maria José.

À Eliane Katibian, pela força e disposição em ajudar desde o início.

À Prefeitura Municipal de Carapicuíba, em especial à Secretaria de Planejamento e Secretaria da Cultura.

Ao IPHAN, pelo apoio técnico do acervo, em especial à Rose por sua gentil prontidão.

Ao Teatro Brincante, aos professores: Rosane Almeida, Lucilene Silva, Cristiane Velasco, Adelson Murta (Adelsin), Maria Amélia Pereira (Peo), Eugênia Nóbrega, Lydia Hortélio, Cristina Cruz e Maria do Carmo Lima (Mary), e amigos - em especial, Alê, Júnior e Synthia - do curso de Educador Brincante, por revelar caminhos tão prazerosos da cultura popular brasileira.

Às crianças da OCA, pela recepção calorosa, pelo carinho e por todos os ensinamentos ao longo desses anos.

À Cris Cruz por ter me recebido de braços abertos na OCA.

À equipe maravilhosa da OCA - Adhê, Aliane, Aninha, Cris Cruz, Ju, Peo, Rose

e Dona Violeta; aos queridos professores Lu, Vera, Mary e Fofão; aos monitores: Adriano, Bibia, Keila, Neném, Nina, Mayara, Paulão e Pingo. E a todos os voluntários e colaboradores.

Ao Moxé, antigo professor da OCA, que trilha novo caminho com as crianças da Aldeia.

À comunidade da Aldeia de Carapicuíba. 
Aos professores e às crianças da Casa Redonda Centro de Estudos.

À Maria Amélia Pereira - a Peo - por ter me acolhido carinhosamente, pela dedicação, e por ter me mostrado o que é o verdadeiro brincar.

A minha família, porto seguro sempre. Aos meus avós maternos, Pedro e Isabel (in memorian), migrantes do sertão nordestino, pelo amor, coragem, cuidado e fé. Aos meus avós paternos, Yoshiro (in memorian) e Sumie, imigrantes japoneses pela luta e esperança.

Aos meus pais, Paulo e Sebastiana, pelo amor, pelo esforço e pela dedicação incondicional. À tia Toninha pelo carinho e cuidado com nossa família.

As minhas irmãs e amigas Adriana, Luciana e Liliana, por conseguir extrair de mim o que tenho de melhor - em especial à Liliana, pela dedicação e paciência ao revisar o trabalho.

Aos meus cunhados, Adriano, Fábio e Luis, por fazerem parte da família - e em especial ao Fábio pelo abstract.

Aos meus sobrinhos amados Sofia e Lucas, por iluminar a nossa família com a pureza do que é ser criança.

A Jacira, minha sogra, pelo carinho e por elevar sempre meu nível espiritual Ao Fábio Pagani, outro cunhado, por me acolher em São Paulo de coração aberto.

As minhas eternas amigas-irmãs: Lisa, Manu, Ná, Gi e Vá, pela amizade fiel, verdadeira e muito divertida. 
À amiga Marcele Silveira, por ter me aberto tantos caminhos, pela amizade e pela prontidão na ajuda de tantas dúvidas. Que, ainda, junto ao amigo Luciano Ferreti iniciamos a caminhada na Fau.

Aos amigos da pós-graduação: Alessandra Navarro, Cristiane Larsen, Pablo Padin e Thais Bortolato, Pier Paolo Pizzolato.

À amiga Lucia Hashizume pelo carinho, pela amizade e por ter aberto um novo caminho para mim.

À amiga Cristina Xavier, por acreditar em mim, pelo apoio e por ter me ensinado como pensar a arquitetura.

À amiga Cris Pasquini, por ter me acolhido no mercado de trabalho quando recém-formada; por ter sempre me incentivado a fazer mestrado e a acreditar em mim.

Aos amigos Antonio Faria e Rosana Mohacsi, pela amizade verdadeira e apoio.

À Arlete e Angélica, pessoas maravilhosas, peças principais no início do meu processo de tomada de consciência. 
Deus quer, o homem sonha, a obra nasce 


\section{RESUMO}

\section{Título: 0 espaço da criança na Aldeia de Carapicuíba}

Propõe uma reflexão sobre a Aldeia de Carapicuíba como elemento essencial na formação do território no Brasil. Esse espaço surgido como aldeamento pela ação dos jesuítas, indica que se tem, desde então, uma relação básica com visão comunitária fundamentada em famílias, seus filhos e suas crianças. Isso se mantém no decorrer do tempo através de sucessivas transformações, inclusive, havendo uma insistência em permanecer no espaço mesmo quando se propôs sua destruição. Contemporaneamente, retomando essa tradição, instalou-se ali a OCA - Associação da Aldeia de Carapicuíba - cujas atividades são voltadas para as crianças com ênfase especial no brincar enquanto exercício fundamental da formação do ser humano. 0 presente trabalho busca compreender a perenidade dessa vocação do espaço da aldeia revivida por meio das atividades lúdicas.

Palavras-chave: Arquitetura - Espaços Culturais - Brincadeiras - Aldeia de Carapicuíba 


\section{ABSTRACT}

\section{Titte: The space of children at Carapicuíba's village}

Proposes a reflection about village of Carapicuíba (named "Aldeia de Carapicuíba") as an essential element in formation of Brazilian territory. That place, aroused as a resort by the action of Jesuits, points that, there is a basic relation with communitarian vision based in families their sons and kids since then. This fact keeps happening through years by successive transformations, its occupation included, even when its destruction was proposed. Contemporaneously, reacting this tradition was installed there, the OCA Associação da Aldeia de Carapicuíba - which activities are for children with a special emphasize in playing situations as a primordial exercise in human being formation. This paper objectives comprehend perennial vocation of space from the village revived through playful activities.

Key words: Architecture, cultural spaces, plays, Carapicuíba's village 


\section{SUMÁRIO 15}

INTRODUÇÃO 19

\section{O ESPAÇO DA CRIANÇA HOJE 31}

1.1.Educação do amanhã - 0 despertar da consciência 33

1.2.0 Brincar e a Cultura da Infância 39

1.2.1.0 Lúdico $\mathbf{4 2}$

1.2.2. 0 Brincar 48

1.2.3. A Cultura Infantil e o Brincar $\mathbf{5 3}$

1.2.4. 0 Folclore Infantil e a Cultura Infantil $\mathbf{5 7}$

1.2.5. Educação da Sensibilidade $\mathbf{6 0}$

1.3.A Criança e o Ambiente Urbano 72

1.3.1. CEU - Centro Educacional Integrado $\mathbf{8 0}$ 


\section{A IDENTIDADE DA ALDEIA DE CARAPICUÍBA 89}

2.1. O Processo de colonização no Planalto Paulistano e os Aldeamentos Paulistas 91

2.1.1.0s Aldeamentos Paulistas $\mathbf{9 7}$

2.2. Histórico da Aldeia de Carapicuíba 113

\subsubsection{Localização 113}

\subsubsection{Caracterização 116}

2.3. A Aldeia como Patrimônio e suas manifestações 121

2.3.1.0 Patrimônio 122

2.3.2. Manifestações da Aldeia 137

\section{A ALDEIA DE CARAPICUÍBA CONTEMPORÂNEA 143}

3.1. 0 entorno da Aldeia de Carapicuíba 148

3.1.1. Implantação do Trecho Oeste do Rodoanel e conseqüências

3.2. Parque Cultural e Ecológico da Aldeia de Carapicuíba 167

3.3. 0 Terreiro da Aldeia hoje: uso e ocupação atual 174 
4. OCA - ESPAÇO DE MANIFESTAÇÃO DA CULTURA INFANTIL 185

4.1. 0 conhecimento da atuação da OCA: história, significado e identidade 187 4.1.1. História e Identidade $\mathbf{1 8 8}$

4.1.2. 0 início 192

4.2. Uma Escola Cultural e suas atividades $\mathbf{1 9 7}$

4.2.1. As Brincadeiras 201

4.2.2. Os Folguedos Populares 204

4.3. 0 espaço da criança na OCA $\mathbf{2 1 9}$

4.3.1.0s espaços ocupados 221

4.3.2. 0 espaço construído para as crianças $\mathbf{2 4 4}$

\section{CONSIDERAÇÕES FINAIS 259}

A Oca na Aldeia, a Aldeia na Oca: relações e contribuições 261

\section{BIBLIOGRAFIA 269}

ANEXOS 279 


\section{INTRODUÇÃO}




\section{INTRODUÇÃo}

A pesquisa volta-se para a reflexão sobre a Aldeia de Carapicuíba, único aldeamento jesuítico remanescente, levando em consideração as relações entre a evolução da sua ocupação, os agentes históricos e a vinculação do seu espaço com a criança contemporânea, em um processo que valida sua atualização.

Procura compreender a formação da Aldeia e seu entorno - hoje Parque Cultural da Aldeia -, sua ocupação e evolução, destacando os principais aspectos que interferiram na produção deste espaço, considerado um elemento do nascimento do Brasil.

0 estudo aborda 0 entendimento da paisagem, sua história, sua identidade e significado, conflitos de interesse, além das manifestações populares tradicionais. 
Para compreender a atualização e perenidade da Aldeia, examina-se o percurso e a atuação da OCA - Associação da Aldeia de Carapicuíba - numa dinâmica existente na apropriação do espaço pensado para as crianças e sua comunidade. Defende que a atuação da OCA acontece por meio do pátio, que se estende para o Parque e este por diversas maneiras chega à Aldeia, introduzindo, então, um novo conceito: 0 de Aldeia Parque, que é a própria atualização da Aldeia de Carapicuíba.

0 objetivo do estudo é compreender a relação da Aldeia de Carapicuíba com a OCA, esta como possível retomada do desígnio da Aldeia, uma atualidade da referência da cultura brasileira. Um exercício que procura entender e considerar a complexidade da natureza do que é atual - OCA e Aldeia Parque - num processo de entendimento da Aldeia como espaço social em contínua transformação e evolução, ainda assim, arraigado na tradição.

A formação da OCA parte da necessidade de se ter espaços para atividades das crianças na Aldeia de Carapicuíba direcionados para a socialização, a criação de laços de solidariedade, 
a promoção da auto-estima, a elaboração de uma sensibilidade voltada para criação, principalmente no campo da arte e cultura.

As atividades realizadas a partir da utilização do próprio corpo individualmente, e em conjunto consubstanciado em brincadeiras, jogos, danças, músicas, desenhos, pinturas, estendem-se para a alimentação, a criação de hábitos saudáveis, o reforço na formação escolar e a reciclagem, pessoal e profissional.

Originou-se um processo orgânico que foi se constituindo numa presença constante, dinâmica, delineando formas próprias. Foram sucessivos os espaços ocupados e assumidos por essa comunidade; a saber: o pátio da Aldeia, a Casa de Cultura, uma edificação nos arredores da Aldeia, e um galpão no entorno. Essa ocupação consecutiva dos espaços diz respeito à construção de um espaço próprio, em uma área em comodato, dentro do Parque Cultural da Aldeia de Carapicuíba, realizado com o apoio de diversas empresas, associados colaboradores e também a própria comunidade. 
0 presente trabalho selecionou esse evento no período de 12 anos para estudar a relação entre a vida e a atividade infantil, dos seus aspectos formativos e os espaços necessários decorrentes.

A realização do estudo implicou na consulta a referências secundárias voltadas para a definição do que é a Aldeia; tanto o "Iocus" geográfico e histórico. Procura ressaltar seus significados maiores e permanentes, inserindo sempre 0 olhar da criança como fio condutor. Realiza-se concomitantemente um trabalho de campo voltado para o reconhecimento da atividade realizada desde 0 seu nascimento até os dias de hoje, buscando traçar as perspectivas do desenvolvimento futuro.

A produção do trabalho de campo surgiu da necessidade direta e pessoal nas atividades envolvidas para compreender no seu cerne dinâmico vital, e, a partir disso, com 0 distanciamento necessário, formular uma visão analítica e crítica do processo realizado e desenvolvido. 
A consideração do último espaço ocupado, de sua realização parcial e a compreensão de suas proposições iniciais e da realidade efetiva de sua ocupação, passou a ser o ponto focal para compreensão da relação espaço, espaço comunitário e desenvolvimento infantil.

Verificou-se a partir desse reconhecimento, que a atividade inicial agregou novos aspectos e outras faixas etárias formando um conjunto coeso, tanto no que diz respeito da atividade em si, quanto no que se refere à apropriação do espaço.

A reflexão sobre esses resultados obtidos passou a se constituir em um todo rico e ilustrativo do tema colocado, e das perspectivas de sua realização e evolução.

Os espaços considerados em sua sequência constituem-se em objeto de análise para a compreensão da evolução e crescimento das atividades desenvolvidas.

0 objetivo como linha diretriz da elaboração feita, que é a relação criança-espaço, ao mesmo tempo em que assumiu outros contornos específicos - como, por exemplo, a ligação da atividade implantada e a continuidade da Aldeia de Carapicuíba, entre outros - também 
extrapola o contexto próprio da universalidade dessa relação e da sua perenidade no processo de sucessão das gerações.

A conclusão dessa reflexão procura ressaltar tais elementos e investigar sobre os seus possíveis desdobramentos no que concerne à indagação a ser continuada e ampliada, como nas atividades que possam vir a agregar nesse núcleo, além da reprodutibilidade do que a Aldeia se encontra e se realiza.

Atualmente, a territorialidade da Aldeia de Carapicuíba mantém-se pela relação com a implantação e vida urbana que se desenvolveu em seu entorno, e posteriores intervenções que objetivaram tanto a preservação da Aldeia quanto a sua manutenção enquanto espaço vivo. Dentre essas atividades, vale ressaltar os trabalhos do arquiteto Luis Saia e do IPHAN que atuaram definitivamente para a obtenção de uma feição permanente, e pela eliminação dos elementos agressores. 
Merece destaque, também, a concretização importante dessas diretrizes por meio do Parque Cultural criado pela Prefeitura Municipal de Carapicuíba nos arredores da Aldeia e do respectivo anel viário de contorno. Essa iniciativa, além de valorizar e preservar o patrimônio básico e fundamental, possui um enorme significado pela extensa e efetiva utilização da população implantada no seu entorno e região, atualizando sua designação como Aldeia Parque. 
A dissertação está estruturada em quatro capítulos:

0 Primeiro Capítulo discorre sobre as questões contemporâneas que permeiam as crianças, no que concerne à sua formação.

Não se pretende abordar profundamente teorias da pedagogia e nem da psicologia. As temáticas sobre a educação, o brincar, e 0 ambiente urbano, são tratadas para mostrar um panorama geral contemporâneo, e, ao mesmo tempo, expor, a importância do brincar na formação da criança, e também da necessidade urgente da educação superar os rígidos e arcaicos conceitos pedagógicos pré-estabelecidos.

0 Segundo Capítulo abrange o processo histórico da formação e organização do espaço do Planalto Paulistano destacando a origem dos aldeamentos, evolução e função colonizadora. Compreende os diversos períodos históricos e a formação do único remanescente dos doze aldeamentos jesuíticos paulista. Destaca sua relevância enquanto patrimônio histórico e humano, por meio da sua implantação e manifestações populares tradicionais existentes até os dias de hoje. 
Já o Terceiro Capítulo contextualiza o território da Aldeia de Carapicuíba. Procura caracterizar o entorno, compreender a ocupação da referida área, e as conseqüências.

Aborda o processo de formação do Parque Cultural da Aldeia de Carapicuíba, e mostra o uso e ocupação atual das casas do quadrilátero histórico.

0 Quarto Capítulo examina a formação, o percurso, e a atuação da OCA - Associação da Aldeia de Carapicuíba - em um processo vinculado à ocupação da própria Aldeia e a relação do seu espaço com a criança contemporânea. Aborda suas atividades e os sucessivos locais ocupados ao longo dos seus 12 anos.

Ao final da presente dissertação, são apresentadas as considerações finais com reflexão que procura investigar os possíveis desdobramentos enquanto atividades que possam vir a agregar no núcleo, e enquanto reprodutibilidade do que a Aldeia se encontra e se realiza. 


\section{O ESPAÇO DA CRIANÇA HOJE}




\section{O ESPAÇO DA CRIANÇA HOJE}

"A maturidade de consciência alcançada por um ser humano depende de como ele vive como criança."

Humberto Maturana e Gerda Verden-Zöller

\subsection{Educação do Amanhã - o despertar da consciência}

[...] uma das vocações essenciais da educação do futuro será o exame e 0 estudo da complexidade humana. Conduziria à tomada de conhecimento, por conseguinte, de consciência, da condição comum a todos os humanos e da muito rica e necessária diversidade dos indivíduos, dos povos, das culturas, sobre nosso enraizamento como cidadãos da Terra... (Morin 2007, p.61)

Há décadas, o mundo passa por um processo excessivo de racionalização e fragmentação do ser humano, apoiado numa busca desenfreada pelo poder e desenvolvimento técnicoeconômico. Fato este que traz conseqüências, no mínimo desastrosas, tanto para a própria humanidade quanto para o planeta e suas relações.

Diante disso, percebe-se que, apesar de todo o desenvolvimento da tecnologia e de diversas áreas do conhecimento, o sistema educacional revela-se falho e pouco eficaz, necessitando de uma reforma radical para enfrentar os problemas de sobrevivência humana que afloram agora no século XXI. 
Portanto, o grande desafio da educação é enfrentar as emergências planetárias e superar as crises da mente, da percepção, e dos valores que acometem os homens.

Assim, a pesquisa sobre a educação tem como objetivo ampliar seu conceito, ultrapassar limites pedagógicos, buscando superar o reducionismo cientificista do século XIX ao qual a pedagogia vigente se vê ainda atrelada comprometendo o próprio objeto de uma investigação. Edgar Morin¹ (2007, p.69-70), o filósofo que reflete sobre o educar do futuro, afirma que "é necessária uma noção mais rica e complexa do desenvolvimento, que seja não somente material, mas também intelectual, afetiva, moral...”.

E, como já é sabida a ineficiência do atual sistema educacional, foi mais oportuno abordar e vislumbrar 0 amanhã, já que 0 arquiteto, como idealizador de projeto, desenha 0 futuro, lançando-se sempre para frente.

[...] Bem sabemos que a palavra desenho tem originalmente um compromisso com a palavra desígnio. Ambas se identificavam. Na medida em que restabelecermos, efetivamente, os vínculos entre as duas palavras estaremos também recuperando a capacidade de influir no nosso viver. Assim o desenho se aproximará da noção de projeto (pró-jet), de uma espécie de lançar-se para frente [...] (ARTIGAS, 1967)

\footnotetext{
${ }^{1}$ Edgar Morin - sociólogo e filósofo Frances, um dos principais pensadores do século XXI. Em 1999, a pedido da UNESCO, fez uma reflexão sobre os saberes fundamentais que a educação do futuro deveria tratar, publicada sob 0 título "Os Sete Saberes necessários à Educação do Futuro".
} 
A partir de uma publicação da UNESCO², em 1998, foram introduzidos novos eixos norteadores da política educacional; o Relatório Delors, que estabelece quatro pilares da educação contemporânea: aprender a ser, a fazer, a viver juntos e a conhecer. Hoje, "a educação só pode ser viável se for uma educação integral do ser humano. Uma educação que se dirige à totalidade aberta do ser humano e não apenas a um de seus componentes".

0 currículo atual ensina mais sobre a individualidade e direitos e pouco sobre cidadania e responsabilidade; cria uma lacuna entre o homem e o meio ambiente; utiliza uma pedagogia cristalizada e, assim, leva ao conhecimento isolado da realidade e das reais necessidades, sendo estas de espírito e não de matéria. Estimulando todos os sentidos e não só o intelecto.

Na realidade, a educação atual, como transmissora de conhecimento, desconhece a verdadeira essência e real tendência aos erros e ilusões do próprio conhecimento. Segundo Morin $(2007$, p.20)

\footnotetext{
2 Título: "Educação: Um tesouro a descobrir. Relatório da Comissão Internacional sobre a Educação para o Século XXl”, 1998 sob coordenação de Jacques Delors.
} 
[...] 0 conhecimento não é um espelho das coisas ou do mundo externo. Todas as percepções são, ao mesmo tempo, traduções e reconstruções cerebrais com base em estímulos ou sinais captados e codificados pelos sentidos.

Assim, a educação, acima de tudo, tem o dever principal de gerar lucidez na humanidade.

0 conhecimento deve ser capaz de contextualizar seu objeto no complexo planetário para que adquira sentido (inteligência geral). Deve também quebrar a supremacia do conhecimento fragmentado, separado em disciplinas ${ }^{3}$ que não criam vínculos entre as partes e 0 todo, pois a realidade (era planetária) está cada vez mais global e multidisciplinar.

Morin defende que o uso da inteligência geral solicita o exercício da curiosidade, ação mais expandida e mais viva na infância e adolescência, "que com freqüência a instrução extingue e que, ao contrário, se trata de estimular ou, caso esteja adormecida, de despertar".

E ainda nos alerta que 0 enfraquecimento da percepção global leva ao amortecimento da responsabilidade e da solidariedade, em que cada um tende a ser responsável somente por sua tarefa e também não sente mais os vínculos com seus concidadãos.

\footnotetext{
${ }^{3}[\ldots]$ o recorte das disciplinas impossibilita apreender o que está tecido junto, ou seja, segundo o sentido original do termo, o complexo. (Morin, 2007, p.41).
} 
[...] A inteligência parcelada, compartimentada, mecanicista, disjuntiva e reducionista rompe 0 complexo do mundo em fragmentos disjuntos, fraciona os problemas, separa 0 que está unido, torna unidimensional o multidimensional. É uma inteligência míope que acaba por ser normalmente cega. Destrói no embrião as possibilidades de compreensão e de reflexão, reduz as possibilidades de julgamento corretivo ou da visão a longo prazo. Por isso, quanto mais os problemas se tornam multidimensionais, maior é a incapacidade de pensar sua multidimensionalidade; quanto mais a crise progride, mais progride a incapacidade de pensar a crise; mais os problemas se tornam planetários, mais eles se tornam impensáveis. Incapaz de considerar o contexto e o complexo planetário, a inteligência cega torna-se inconsciente e irresponsável. (Morin, 2007 p.43)

Então, declara que o século XX, mesmo com elevadíssimos avanços na área de conhecimento científico e tecnológico, foi dominado pela pseudoracionalidade, atrofiando a compreensão, a reflexão e a visão em longo prazo. Tornou-se cego diante dos problemas fundamentais, globais e complexos, o que levou aos incontáveis erros e ilusões.

E ainda sustenta que a educação do amanhã tem a obrigação de ser universal e centrada na condição humana, ou seja, nos situar no universo, questionando a nossa posição no mundo. Deve restaurar a unidade complexa da natureza humana para que cada um, onde quer que esteja, tome consciência e conhecimento, de sua identidade complexa e de sua identidade comum a todos os outros humanos. Também tem o dever de buscar contribuições nas ciências humanas, "não somente a filosofia e a história, mas também a literatura, a poesia, as artes...". 
Apesar dos avanços nas telecomunicações, com o rápido acesso a informações por meio dos telefones, celulares e da internet, a incompreensão permanece geral e deteriora as relações entre os homens. Morin (2007, p. 97) constata que "a incompreensão de si é fonte muito importante da incompreensão de outro. Mascaram-se as próprias carências e fraquezas, o que nos torna implacáveis com as carências e fraquezas dos outros."

Assim a educação do futuro teria como missão espiritual ensinar a "compreensão entre as pessoas como condição e garantia da solidariedade intelectual e moral da humanidade" (MORIN, 2007 p. 93). 


\subsection{Brincar e a Cultura da Infância}

"O Homem só é inteiro quando brinca; e é somente quando brinca que ele existe na completa acepção da palavra: Homem."

Friedrich Schiller

Hoje, grande parte da educação infantil ainda apresenta posturas autoritárias e desconexas com a realidade da criança; não respeita sua natureza e não a reconhece como sujeito social. Tem dificuldade de considerar a criança como um ser capaz e competente, afastando-a do mundo em que vive e da cultura em que está inserida.

Acabam por simplificar os conteúdos e a desconsiderar aquilo que a criança já sabe, imaginando que ela é um recipiente vazio. Também não consideram que existe uma Cultura da Infância e que a criança tem uma maneira lúdica de interagir com o mundo, ignorando a linguagem infantil universal - o brincar, que é o seu processo de conhecimento. 
0 brincar é a própria força da sociedade e da civilização, um colapso nesta capacidade de brincar se refletirá num colapso da sociedade.

Um dos maiores desafios da educação que se compromete com a formação integral do ser humano é a consciência do brincar como uma linguagem de conhecimento. A escola, surge como espaço de encontro e de expressão dessa teia de relações vinculadoras que acontecem através das brincadeiras. É importante ampliar 0 espectro da abordagem educacional que até então se constituiu unicamente com a função de transmitir 0 conhecimento.

Na verdade, essa mudança radical trata de um novo olhar que opera em um tempo marcado pela complexidade e pela crise do modelo de ciência que dominou os últimos séculos.

A busca de novos caminhos vem provocando o surgimento de novos paradigmas (holomônicos, holistas, de complexidade) que, no entanto, só podem, neste momento, ser configurados por via especulativa, pois estão em constituição. (SOUZA SANTOS, 1988) 
São paradigmas que pressupõe uma comunicação - elaboração transdisciplinar entre diferentes áreas do conhecimento, oposta ao isolamento disciplinar característico do paradigma clássico.

Trata-se da composição de outra lógica que procura ler o complexo real sob a aparência simples dos fenômenos tais como se nos apresentam.

Não deverá mais existir um corte separando o sujeito do objeto, 0 imaginário da razão, 0 sagrado do profano. Não porque um dos temas desse dualismo ancestral se reduziria ao outro, mas porque são ambos significantes de um mesmo significado - tertum datum - que estrutura os dois. (DURAND, 1995, p.20)

Assim, para fornecer um panorama sobre a criança e educação, a pesquisa busca fundamentação na importância do brincar e no reconhecimento da existência da Cultura da Infância. Apesar de não pretender uma abordagem profunda, foram observados estudos de vários autores das diversas áreas: pedagogia, antropologia, psicologia do desenvolvimento infantil, percepção ambiental, filosofia e sociologia como referencial teórico. 


\subsubsection{Lúdico}

"Ludus est necessarius ad conversationem humanae vitae."

( 0 brincar é necessário para a vida humana)

Tratado sobre o brincar - Tomás de Aquino

Permeando por entre abordagens filosóficas, a pesquisa referência sobre o lúdico é a do filósofo alemão Johan Huizinga que, em seu livro de 1938 - Homo Ludens procura integrar 0 conceito de jogo no de cultura, afirma que "é no jogo e pelo jogo que a civilização surge e se desenvolve".

De certa forma 0 autor se distancia da esfera biológica e científica, aborda o lúdico como fenômeno cultural, inserido numa perspectiva histórica. Declara que (2001, p.3)

[...] o jogo é mais do que um fenômeno fisiológico ou um reflexo psicológico. Ultrapassa os limites da atividade puramente física ou biológica. É uma função significante, isto é, encerra um determinado sentido. No jogo existe alguma coisa 'em jogo' que transcende as necessidades imediatas da vida e confere um sentido à ação. Todo jogo significa alguma coisa... 0 simples fato de 0 jogo encerrar um sentido implica a presença de um elemento não material em sua própria essência [...] 
Assim, Huizinga defende que o lúdico possui uma realidade autônoma, que ultrapassa a esfera da vida humana, que não está ligado a nenhum grau de civilização ou qualquer concepção do universo.

Analisa 0 jogo como função social, uma atividade voluntária presente nas mais diversas manifestações sociais: na linguagem, nos rituais, na música, na dança, na poesia, no saber e até nas regras de guerra. Outra característica ressaltada define o jogo como uma 'fuga' da vida real - "o fazer de conta". E afirma ainda que pertence à dimensão do sagrado ${ }^{4}$, sendo "uma atividade temporária, que tem uma finalidade autônoma e se realiza tendo em vista uma satisfação que consiste nesta própria realização".

Além disso, 0 autor (2001, p.13) acentua que 0 jogo cria ordem e é ordem concomitantemente; "introduz na confusão da vida e na imperfeição do mundo uma perfeição temporária e limitada, exige uma ordem suprema e absoluta" e, por isso, está

\footnotetext{
4 "A representação sagrada é mais do que a simples realização de uma aparência, é até mais do que uma realização simbólica: é uma realização mística. Algo de invisível e inefável adquire nela uma forma bela, real e sagrada. Os participantes do ritual estão certos de que 0 ato concretiza e efetua uma certa beatificação, faz surgir uma ordem de coisas mais elevada do que aquela que habitualmente vivem" (Huizinga, 2001, p17).
} 
intimamente ligado ao domínio da estética, por possuir também ritmo e harmonia, além de outras características singulares à descrição dos "efeitos da beleza: tensão, equilíbrio, compensação, contraste, variação, solução, união e desunião".

Define como função do jogo a luta por algo ou a representação (como exibição) de alguma coisa. Huizinga (2001, p.17) complementa que

A criança representa alguma coisa diferente, ou mais bela, ou mais nobre, ou mais perigosa do que habitualmente é... Fica literalmente "transportada" de prazer, superandose a si mesma a tal ponto que quase chega a acreditar que realmente é esta ou aquela coisa, sem contudo perder inteiramente 0 sentido da "realidade habitual". Mais do que uma realidade falsa, sua representação é a realização de uma aparência é "imaginação", no sentido mais original do termo.

Assim, Huizinga (2001, p.33) nos dá a noção de jogo como sendo

[...] uma atividade ou ocupação voluntária, exercida dentro de certos e determinados limites de tempo e de espaço, segundo regras livremente consentidas, mas absolutamente obrigatórias, dotado de um fim em si mesmo, acompanhado de um sentimento de tensão e de alegria e de uma consciência de ser diferente da "vida quotidiana". 
Friedrich Schiller

Outra abordagem filosófica ocorreu, também, nas primeiras décadas do século XX: o filósofo alemão Walter Benjamin ${ }^{5}$ refletiu sobre a educação - uma das suas grandes inquietações. Seus ensaios falam sobre a criança, a juventude, jogos e brinquedos no contexto da educação do cidadão.

Delimita, ainda, a existência de uma cultura da criança ${ }^{6}$ e defende a idéia de "garantir às crianças a plenitude da infância", pois "todas as manifestações na vida infantil não pretendem outra coisa senão conservar em si os sentimentos essenciais" (2002, p.49). 0 autor mostra que as crianças fazem parte do povo e da classe a qual pertencem, não constituindo uma comunidade isolada.

\footnotetext{
${ }^{5}$ Textos escritos entre 1913 e 1932, reunidos no livro: "Reflexões sobre a criança, o brinquedo e a educação", tradução de Marcus Vinicius Mazzari, 2002.

6 "as crianças não constituem nenhuma comunidade isolada, mas antes fazem parte do povo e da classe a que pertencem. Da mesma forma, os seus brinquedos não dão testemunho de uma vida autônoma e segregada, mas são um mudo diálogo se sinais entre a criança e o povo." (Benjamin, 2002, p.94)
} 
Deixa claro que a experiência lúdica proporciona o nascimento da auto-reflexão. E que a essência do brincar não é um "fazer como se" e sim um "fazer sempre de novo", que é a "transformação da experiência mais comovente em hábito" (2002, p.102).

Para Benjamin, pensador sensível ao universo da criança, o brincar e o brinquedo "formam um par dialético que traduz o relacionamento entre 0 adulto e a criança". Declara que (2002, p.93)

[...] Hoje talvez se possa esperar uma superação efetiva daquele equívoco básico que acreditava ser a brincadeira da criança determinada pelo conteúdo imaginário do brinquedo, quando, na verdade, dá-se o contrário. A criança quer puxar alguma coisa e torna-se cavalo, quer brincar com areia e torna-se padeiro, quer esconder-se e torna-se bandido ou guarda. Conhecemos muito bem alguns instrumentos de brincar arcaicos, que desprezam toda máscara imaginária (possivelmente vinculados na época a rituais): bola, arco, roda de penas, pipa - autênticos brinquedos, tanto mais autênticos quanto menos 0 parecem ao adulto. Pois quanto mais atraentes, no sentido corrente, são os brinquedos, mais se distanciam dos instrumentos de brincar; quanto mais ilimitadamente a imitação se manifesta neles, tanto mais se desviam da brincadeira viva.

[...] os seus brinquedos não dão testemunho de uma vida autônoma e segregada, mas são um mudo diálogo de sinais entre a criança e o povo. (2002, p.94)

E critica que o brincar tem sido visto sob a ótica do adulto, sob o ponto de vista da imitação. 
Todo o pensamento humano é representação, isto é, passa por articulações simbólicas encontrando-se, pois subjacente com os modos de pensar, sentir e agir dos indivíduos, das culturas, das sociedades.

A representação que 0 brincar carrega não pode ser entendida como uma simples reprodução e tradução de uma realidade exterior, uma vez que engloba o domínio da fantasia ultrapassando a simples representação intelectual.

Sendo o universo simbólico das brincadeiras possuidor de um caráter eminentemente imaginário, o brincar representa uma rede na qual o sentido é dado pela "relação" constituindo-se no dinamismo organizador das vivências que a criança vai estabelecendo consigo própria, com o mundo e com 0 outro. 


\subsubsection{Brincar}

"Brincar é a mais elevada forma de pesquisa." Albert Einstein

Segundo Joseph Chilton Pearce (1992), cientista e pesquisador da inteligência humana, 0 brincar está presente na base da inteligência criativa, mas necessita ser desenvolvida. É a tarefa principal da primeira infância e cria a base da capacidade simbólico-metafórica “ "tanto do pensamento concreto quanto do pensamento operacional",

[...] A linguagem simbólico-metafórico é capaz de sugerir estados sutis que, em si mesmos, não podem ser articulados. É por isso que a poesia é um grande instrumento para elevar a mente, tirar-lhes as raízes da matéria. Ela pode evocar, ou trazer de volta, sentimentos, anseios e aspirações indisponíveis ao pensamento, lógica ou descrição discursiva.

A contação de histórias é uma das bases do brincar, a criança ouve atentamente e fica imóvel enquanto sua visão é transportada para 0 lugar onde ocorre a ação da história (estímulo de imagens internas correspondentes) e em seu cérebro ocorrem ações de novos campos neurais e novas conexões entre si. Pearce (1992, p.159) afirma que

\footnotetext{
7 “Toda e qualquer forma de brincar é um exercício de pensamento simbólico-metafórico, a base da erudição e de todos os estudos mais avançados". (Pearce, 1992, p.163)
} 
[...] quanto mais forte e permanente se torna a capacidade de interação verbo-visual, mais fortes se tornam a conceitualização, a imaginação e a atenção, enquanto 0 escopo e a flexibilidade das capacidades neurais em geral aumentam.

Porém, com 0 advento da televisão, a narração de histórias perdeu espaço nas vivências das

crianças, além de ter diminuído drasticamente o diálogo entre a família. As relações entre

pais e filhos foram prejudicadas e as brincadeiras também foram perdendo espaços nos

lares.

[...] A televisão inunda de imagens o cérebro do bebê e da criança justamente no momento em que esse cérebro deve aprender a formar imagens interiores. A narração de histórias propicia um estímulo que provoca uma reação de formação de imagens que envolve cada aspecto do nosso sistema tri-uno. A televisão propicia ao cérebro do bebê e da criança não só o estímulo, mas também a reação, como um efeito emparelhado e único, e aí está o perigo. A televisão enche 0 cérebro com uma reação falsificada, que imita aquela que ele deve aprender a mostrar diante dos estímulos das palavras e ou da música. Em decorrência disso, elimina-se boa parte do acoplamento estrutural entre a mente e 0 ambiente, desenvolvem-se poucas imagens metafóricas e poucas ou quase nada estruturas simbólicas $[\ldots]$ 
Assim, o não-desenvolvimento de imagens é traduzido na falta de imaginação ${ }^{8}$, significando dificuldade no aprendizado. Seu cérebro é colocado 'para dormir', impedindo 0 desenvolvimento neural, visto que não precisa de quase nenhuma energia para processar 0 que está se passando na TV. Além disso, aprisiona o corpo da criança, que necessita do movimento para desenvolver uma vida saudável, já que a aprendizagem nessa fase é basicamente sensório-motora.

Já Maturana e Verden-Zöller (2004) afirmam em seus estudos que o brincar, junto com 0 amar, são fundamentos esquecidos do humano ${ }^{9}$. Eles referem-se a fundamentos da condição humana que permeiam o lúdico.

\footnotetext{
8 "Um recente estudo mostrou que as crianças que têm pouca imaginação são muito mais propensas à violência que as crianças imaginativas, pois não conseguem imaginar uma alternativa quando a informação sensorial imediata é ameaçadora, ofensiva, desagradável ou pouco compensadora. Elas atacam tudo que é desagradável com a atitude defensiva, ao passo que as crianças dotadas de imaginação podem pensar numa alternativa, isto é, criar imagens que, não estando presentes ao sistema sensorial, Ihes forneçam uma saída." (Pearce, 1992, p.170)

${ }^{9} 0$ curso da história humana se desenrola geração após geração. É essa mesma trajetória que segue o emocionar adquirido pelas crianças no crescimento em relação com seus pais, outros adultos, outras crianças e com o mundo não-humano circundante. Nessas, circunstâncias, para compreender as mudanças culturais, devemos entender as alterações históricas do emocionar humano em sua relação com o crescimento das crianças. (Maturana e Verden-Zöller, 2004, p.12)
} 
Em uma das pesquisas, Verden-Zöller (p.141) conclui que a consciência individual e social da criança surge por meio "das suas interações corporais com as mães, numa dinâmica de total aceitação mútua na intimidade do brincar". Ainda diz que

[...] 0 Eu é uma dimensão social humana que se realiza por meio de uma dada corporeidade e surge como um entrecruzamento específico das diferentes conversações que constituem e definem a comunidade social em que esse Eu vive com outros Eus em mútua aceitação. Portanto, toda criança deve adquirir seu Eu - ou identidade individual social - como uma forma particular de ser em sua corporeidade, mediante o viver numa comunidade específica de mútua aceitação. Isso ocorre naturalmente, à medida que a criança cresce na estreita intimidade do encontro corporal, em confiança e total aceitação de sua mãe, bem como na de todas as crianças e adultos com as quais convive [...]

Para a autora,, o brincar na vida diária é qualquer atividade vivida no presente de sua realização, de maneira emocional e sem nenhum objetivo. É atentar para 0 presente. Maturana (2004, p. 231) completa que "0 brincar não tem nada a ver com o futuro. Brincar não é uma preparação para nada, é fazer o que se faz em total aceitação, sem considerações que neguem sua legibilidade".

Ao brincar, as crianças constroem suas relações espaciais, seus domínios de ações e as configurações sensório-motoras. E enquanto vivenciam as experiências recorrentes de 
movimento, tocando, balançando e fazendo ritmos, elas constituem e desenvolvem gradualmente o conhecimento operacional de seus corpos.

Defendem que o brincar é importante para desenvolver na criança a sua autoconsciência, consciência social e de mundo, além de desenvolver seu auto-respeito e auto-aceitação.

E Maturana (2004, p. 232) diz que

Perdemos nossa consciência social individual à medida que deixamos de brincar. E assim, transformamos nossas vidas numa contínua justificação de nossas ações em função de suas conseqüências, num processo que nos torna insensíveis em relação a nós mesmos e aos demais.

Verden-Zöller (2004, p.187) declara que essas brincadeiras ditas como espontâneas "não são arbitrárias e sim dinâmicas corporais ligadas a territórios ancestrais de comportamento"; provém da história evolutiva da espécie humana.

Assim, Maturana e Verden-Zöller (2004, p.245) concluem que a cultura contemporânea ocidental

[...] Nega o brincar como aspecto central da vida humana, mediante sua ênfase na competição, no sucesso e na instrumentalização de todos os atos e relações. Acreditamos que para recuperar um mundo de bem-estar social e individual - no qual o crime, 0 abuso, o fanatismo e a opressão mútua não sejam modos institucionalizados de viver, e sim erros ocasionais de coexistência - devemos devolver ao brincar o seu papel central na vida humana. Também cremos que para que isso aconteça devemos de novo aprender a viver nessa atmosfera. 


\title{
1.2.3. A Cultura Infantil e o Brincar
}

\author{
"Ao anoitecer brincamos as cinco pedrinhas \\ No degrau da porta de casa \\ Graves como convém a um deus e a um poeta, \\ E como se cada pedra \\ Fosse todo um universo \\ E fosse por isso um grande perigo para ela \\ Deixá-la cair no chão." \\ Fernando Pessoa
}

Para Lydia Hortélio ${ }^{10}$, educadora e etnomusicóloga baiana, a Cultura Infantil é o fazer espontâneo das crianças entre elas mesmas na busca de si e dos outros, em interação com o mundo. "A Cultura da Criança se faz brincando". É o acervo dessas experiências "que desabrocha em inteireza e liberdade".

Segundo ela, este acervo cria um corpo de conhecimento, na realidade, "conhecimento com o corpo" que é comunicado de geração em geração, sem quaisquer fronteiras e nos chega por meio dos brinquedos de criança. Defende que o brinquedo é um gesto da evolução, um impulso de vida como forma de realização e crescimento; e por meio dele podemos

\footnotetext{
${ }^{10}$ Lydia Hortélio, baiana, com formação em Música: piano, educação musical e etnomusicologia. Estudou no Brasil, Alemanha, Portugal e Suíça. É pesquisadora da Música da Cultura Brasileira e da Cultura Infantil. Lançou em 2003 o CD "Abre a roda tindolelê" e "Ó Bela Alice" em 2004
} 
compreender a índole e a natureza do Ser Humano e também conhecer a Cultura de um Povo.

Lydia declara que a Natureza é o verdadeiro espaço das crianças; somente vivenciando no seu genuíno habitat é que ela consegue espontaneamente compreender com o corpo e desenvolver uma inteligência sensível, ou seja, existir em "inteireza", manifestar suas carências infinitas de movimento.

A inteireza vive do completo assentimento, e a inspiração, o impulso interno que a move, corporifica-se no brinquedo que se quer, que se precisa: este e não aquele. $E$ aí está a oportunidade de libertação. No fenômeno lúdico fecha-se o círculo mágico da vida: eu, 0 outro, o mundo, o Universo que se dão as mãos num Brinquedo de Criança.

E nesse contexto, busca-se uma compreensão da Música da Cultura infantil, na qual define como,

[...] Uma música com movimento, aliada à representação e a uma geometria no tempo. É uma música no corpo, próxima ao outro, com o outro, movida pura e simplesmente pela livre vontade de brincar. É a cidadania plena, por índole e direito, sensível e inteligente. Sua prática proporciona 0 exercício espontâneo da música em todas as suas dimensões, mesmo que de forma elementar, e se constitui, por si mesma, a base de uma educação do sensivel e pressuposto fundamental da identidade cultural. 
Desde muito cedo as crianças convivem com música, desde os acalantos no colo da mãe quando bebê, pelas parlendas e cantilenas ${ }^{11}$, depois, nos brinquedos cantados e mais tarde nas rodas de versos, considerados "verdadeiros ritos de passagem, em que o conteúdo poético, a atmosfera própria e a movimentação, mesmo guardando dimensões da infância, apontam, cada vez mais, a expressividade da nova etapa a ser vivida”.

Sendo então importante 0 seu resgate, pois a "Música Tradicional Infantil representa em todas as culturas a expressão mais sensível da alma de um povo" - a alma ancestral, os arquétipos da nossa cultura.

Lydia acredita que devemos refletir sobre 0 sentido da nossa origem e 0 valor da nossa cultura para, assim, despertar uma "consciência de Brasil”, uma busca pela construção de uma identidade brasileira. E através da prática da Música da Cultura Infantil,

[...] restabelecer o laço efetivo com a língua - a língua mãe, aquela que os poetas populares ainda conhecem, e com a língua mãe musical - a canção popular, começando pelos Brinquedos Cantados, tão carregados do encanto e dos mistérios da Infância da raça, dos múltiplos arquétipos de nossa Cultura. (Hortélio,1998 apud CRUZ, 2005, p.78)12

\footnotetext{
${ }^{11}$ Parlendas são versinhos com temática infantil recitados em brincadeiras de crianças. Possuem rima fácil e, por isso, são populares entre as crianças. Já cantilenas são pequenas cantigas suaves, ladainha, lengalenga.

${ }^{12} 10$ HORTELIO, Lydia. Análise e Sugestões - Referencial Curricular Nacional para a Educação Infantil, Salvador, 1998.
} 
Desse modo, sustenta que a transformação virá por meio de uma educação consciente de uma compreensão da criança, por meio da Cultura da Criança, inspirada na cultura do povo brasileiro. Lydia afirma que

[...] Ela carrega em seus fundamentos, os arquétipos, invenções, os gestos, os sentimentos específicos de cada uma de suas vertentes formadoras e as transposições nascidas de uma miscigenação espontânea e infinita. É importante afirmar a cultura infantil da criança brasileira porque ela traz em seu nascedouro, o manancial extraordinário de uma cultura mestiça, o projeto próprio de desenvolvimento da raça a ser transcendido pela força da Alma do Brasil. (Hortélio,1998 apud CRUZ, 2005, p.79) 


\subsubsection{Folclore Infantil e a Cultura Infantil}

0 sociólogo Florestan Fernandes, ainda estudante da Faculdade de Filosofia, Ciências e Letras iniciou, em 1941, seus primeiros levantamentos sobre 0 folclore paulistano nos bairros de imigrantes e populares da cidade de São Paulo. Posteriormente, foram recolhidos os vários ensaios feitos daquele ano até 1959 para a publicação do livro Folclore e mudança social na cidade de São Paulo, em 1961.

0 autor preocupou-se com as influências socializadoras do folclore, principalmente 0 folclore infantil. Chamava a sua atenção "os conhecimentos de significação social, que as crianças podiam adquirir através da participação das "trocinhas' ${ }^{13}$ ou dos grupos infantis" (FERNANDES, 2004, p.14). Comprovou que o folclore infantil tinha influência na formação da personalidade da criança e que esses grupos iniciam a criança na vida social.

\footnotetext{
${ }^{13}$ Trocinhas é um termo usado pelas próprias crianças da época da pesquisa (década de 40) para designar os grupos infantis, principalmente os formados nas ruas.
} 
Descobriu que, por meio dos folguedos, as crianças têm oportunidade de manter contatos pessoais no seu próprio meio, ou seja, "com pessoas que possuem a mesma idade, os mesmos centros de interesse, a mesma concepção do mundo e o mesmo prestígio social", muito diferente das relações com os adultos.

Elas alargam, assim, sua área de contatos humanos, aprendem de modo mais acessível as vantagens e 0 significado das atividades organizadas grupalmente, experimentam os diferentes papéis associados às relações de subordinação e de dominação entre pessoas da mesma posição social e se identificam com interesses ou com valores cujas polarizações de lealdade transcendem ao âmbito da família. (FERNANDES, 2004, p.16)

Fernandes (2004) defende também a existência de uma Cultura Infantil que é constituída por elementos quase exclusivos das crianças e de natureza lúdica. Também detecta que esses elementos vêm da cultura do adulto que passam por um processo de aceitação por parte das crianças incorporando à sua maneira, além de conjuntamente elaborarem os elementos de sua própria natureza. Fernandes (2004, p.219) nos chama a atenção sobre 0

Aspecto de socialização elaborado no seio dos próprios grupos infantis, ou seja: educação da criança, entre as crianças e pelas crianças. A criança é modelada, é formada, também, através dos elementos da cultura infantil, pois estes elementos põem-na em contato direto com os valores da sociedade. 
Ou seja, nas próprias palavras do sociólogo "a verdadeira aprendizagem, em que o mestre da criança é a própria criança" (2004, p.18). 


\subsubsection{Educação da Sensibilidade}

“Amanhã, para que a espécie sobreviva, Vamos ter que implodir os prédios Para construir jardins da infância."

Maria Amélia Pereira - Peo

Foi por meio das conversas e convivência com a pedagoga Maria Amélia Pereira ${ }^{14}$, que a pesquisa sobre o brincar tomou corpo, aliás, ganhou alma nesta dissertação.

Maria Amélia é fundadora e orientadora da Casa Redonda Centro de Estudos ${ }^{15}$, um espaço de educação infantil, nascido no início dos anos 80 em uma chácara na cidade de Carapicuíba, região metropolitana de São Paulo. Pode-se dizer que a Casa Redonda é 0 "útero" gerador da OCA - Associação da Aldeia de Carapicuíba.

\footnotetext{
${ }^{14}$ Maria Amélia Pereira mais conhecida como Peo, nasceu em Salvador, Bahia. É pedagoga com especialização em Cinesiologia. Orientadora da escola Vera Cruz, em São Paulo, de (1963 à 1076) e de 1982 a 1986), Assessora Pedagógica da unidade de Tratamento de paralisia cerebral do SARAH Instituto Nacional de Medicina do Aparelho Locomotor (1977-1978)Coordenadora do Programa do Núcleo Experimental de Atividades Sócio-Culturais da Prefeitura do Município de Salvador(1979 a 1982). Membro do Vconseho International do IPA- International Playing Association for the Child Right to Play( 1990-1999). Vice- Presidente do Instituto Brincante (2002 a 2009) Fundadora e Orientadora do Centro de Estudos Casa Redonda (1983 a 2009).

${ }^{15}$ Para mais informações sobre o trabalho da Casa Redonda, consultar : CRUZ, Maria Cristina Meirelles Toledo. Para uma educação da sensibilidade: a experiência da Casa Redonda Centro de Estudos. Dissertação de Mestrado, ECA/USP, São Paulo, 2005.
} 
É pertinente uma breve apresentação de sua vivência para contextualizar o percurso como educadora e, assim, ter melhor compreensão dos conceitos por ela defendidos.

Maria Amélia vem inicialmente de uma formação de magistério em Salvador. Desde cedo optou por trabalhar diretamente com as crianças: dos 12 aos 17 anos se uniu a um grupo de estudantes para participar de atividades em uma favela vizinha do bairro onde morava. Em seguida, criou um espaço de brincar que reunia as crianças no quintal da sua casa. Vivenciou como estagiária a experiência da Escola Parque de Salvador ${ }^{16}$, projeto educacional da área pública idealizado pela equipe de professores liderada pelo Prof. Anísio Teixeira ${ }^{17}$. Esta foi 0 embrião das demais experiências de educação publica com tempo integral que aconteceram no Brasil, como: Escolas Vocacionais, CIEPS, CEUs etc...

Conviveu com o filósofo português Agostinho da Silva, com o qual pode comungar e refletir sobre a essência das crianças e a identidade do brasileiro, ideais que guiam até hoje a sua

\footnotetext{
${ }^{16}$ Consultar : DUARTE, Hélio de Queiroz. Escola-classe escola-parque. São Paulo: FAUUSP, 1973.

${ }^{17}$ Anísio Spínola Teixeira, nascido em 1900 em Caetité, Bahia. Formou-se em direito, foi intelectual, educador e escritor. Personagem principal na história da educação do Brasil.Foi discípulo e divulgador da filosofia do educador John Dewey. Difundiu os ideais da Escola Nova entre as décadas de 20 e 30, que tinha como princípio a ênfase no desenvolvimento do intelecto e na capacidade de julgamento, em detrimento da memorização. Fundou a Universidade do Distrito Federal em 1935 que depois foi transformada em Faculdade Nacional de Filosofia da Universidade do Brasil. Reformulou o sistema educacional da Bahia com a criação da Escola Parque em Salvador. Morreu em 1971 no Rio de Janeiro em circunstâncias obscuras, pode ter sido vítima da repressão do governo Médici.
} 
prática em educação. Também teve contato com 0 método de alfabetização do professor Paulo Freire, experiência que proporcionou olhar o papel da educação também no plano político-pedagógico.

Em 1963, mudou-se para São Paulo onde integrou um curso de formação de professores sobre 0 método Montessori-Lubienska. Logo em seguida é convidada a fazer parte da formação da Escola Experimental Vera Cruz, que tinha uma nova visão de educação; onde 0 educador era considerado "agente crítico e reflexivo de sua prática educativa" (CRUZ, 2005, p.23-24). Sua experiência, ao longo de 16 anos, passou de estagiária a sócio-fundadora. Neste período, paralelamente a atuação na Escola Experimental, iniciou o curso de pedagogia na PUC-SP, fato este que comprovou o quanto a teoria universitária se afastava da real prática educacional brasileira.

Nos anos 70 ocorreu uma reforma no ensino cuja proposição era a união das metodologias do primário com o ginásio, fato que revela, no sistema de educação, uma burocratização e um endurecimento, distanciando cada vez mais o discurso teórico da prática efetiva. 
Assim, em 1975, Maria Amélia decide afastar-se da atuação na escola e segue para Brasília. Lá atuava como voluntária na Comunidade Terapêutica do Hospital Sarah Kubitschek com atividades lúdicas para crianças com deficiência física. Neste período, longe da escola, pode refletir sobre o professor e sua prática. Iniciou uma "pesquisa do repertório gestual das brincadeiras espontâneas das crianças que se encontravam fora das escolas... 0 que possibilitou a compreensão da existência de uma Cultura Infantil”. (CRUZ, 2005, p.30).

Este contato que retomou com as crianças de periferia foi um descortinar sobre 0 quê a incomodava dentro da escola: 0 massacre dos valores cognitivos e a visão estruturalista sobre a espontaneidade, a alegria, o entusiasmo das crianças.

Após dois anos em Brasília, volta para Salvador onde participa, junto com Lydia Hortélio, da criação de um espaço público de educação em um parque ${ }^{18}$, fundamentado nas reflexões de Anísio Teixeira.

No início dos anos 80 retorna à São Paulo e se dedica-se à criação de um curso de formação de educadores na Escola Vera Cruz. Propunha a reformulação do currículo apoiado

${ }^{18}$ Sobre essa experiência, consultar HORTÉLIO, Lydia. História de uma manhã. São Paulo:Massao Ohno, 1987. 
em uma educação que valorizasse a Cultura Infantil de mãos dadas com a Cultura Brasileira. 0 projeto foi reconhecido, mas exigia uma reorganização curricular considerada avançada pela Escola e pelo Conselho Estadual de Educação da época.

Assim, volta à sua pesquisa e vivência das brincadeiras de rua, mas agora na periferia de Carapicuíba, na Vila Ariston. Registrou o processo das brincadeiras de pião, bola de gude e pipa, esta última mais detalhada que, posteriormente, foi apresentada em um Encontro Internacional na Argentina e Washington.

0 médico e psicoterapeuta húngaro Pethö Sándor, que desenvolveu a Calatonia no Brasil uma técnica de integração fisio-psiquica a partir de uma abordagem corporal por meio de toques sutis - marca uma forte influência em Maria Amélia, que declara:

\footnotetext{
"a relação psicossomática, presente na atuação das crianças enquanto brincam, abriu a porta para minha indagação sobre 0 ato de brincar como um processo espontâneo de auto-regulação do desenvolvimento da criança, referendando a "sabedoria do corpo", em busca dos gestos que the conduzem a uma maturação físio-psíquica. (CRUZ, 2005, p.31)
} 
Também integrou o conselho de uma Organização Internacional sobre o Direito de Brincar, IPA - Internacional Playing Association - entre 1985 e 1990. Apresentou vários trabalhos sobre suas pesquisas das brincadeiras espontâneas de rua, viajando por diversos países.

Nesse intervalo de 20 anos dedicou-se, também, a treinamentos de professores de creches, a pedido das Secretarias de Educação de vários estados brasileiros, para introduzi-los a uma nova compreensão do processo de desenvolvimento da criança sob o reconhecimento do Brincar como uma linguagem de conhecimento, e que define uma cultura própria da Infância.

Em meados de 1994, Maria Amélia, junto com Antonio Nóbrega e sua esposa Rosane Almeida, criaram um curso para formação de educadores no Teatro Escola Brincante ${ }^{19}$, baseado naquele projeto elaborado para a Escola Vera Cruz nos anos 80.

0 curso em sua estrutura permite 0 contato direto com a cultura popular brasileira e difunde a importância desta na formação das crianças e adolescentes. Oferece 0 estudo e a prática

\footnotetext{
${ }^{19}$ Ver anexo: breve relato do curso "Educador Brincante" feito em 2007 como parte da pesquisa sobre a cultura popular brasileira e 0 brincar
} 
de cantos, danças, toques instrumentais, histórias, brinquedos e brincadeiras, ou seja, aspectos que alimentam a cultura popular e possibilita a reflexão sobre o Brasil.

Em 1996, Maria Amélia une-se à psicóloga Maria Cristina Meirelles Toledo $\mathrm{Cruz}^{20}$ e a outros profissionais, principalmente por pais dos alunos da Casa Redonda, e inicia um trabalho com as crianças da Aldeia de Carapicuíba. Cria-se uma Escola Cultural, a OCA - Associação da Aldeia de Carapicuíba, um espaço onde as crianças têm acesso à cultura brasileira por meio dos cantos, das danças, artes, mitos, histórias e brincadeiras.

[...] Acreditando que uma vez inserido no corpo dessas crianças esse repertório criativo, elas poderão descobrir a si próprias como seres vivos, com uma identidade que thes permita se integrar na comunidade e ocupar o seu lugar. (CRUZ, 2005, p.32)

${ }^{20}$ Maria Cristina M. Toledo Cruz é educadora da Casa Redonda Centro de Estudos, com formação em psicologia e especialização em Arte Educação, hoje é diretora executiva da OCA e autora da dissertação de mestrado "Para uma Educação da Sensibilidade: a experiência da Casa Redonda Centro de Estudos", defendida na Escola de Comunicação e Artes - ECA/USP em 2005. 


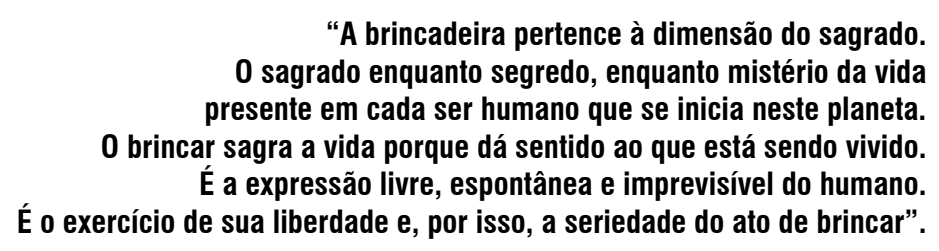

Maria Amélia Pereira - Peo

Maria Amélia defende o brincar como linguagem universal da Cultura da Infância e o espaço da natureza como o seu habitat. Mas, alerta que há total ignorância sobre quem é a criança brasileira; grande parte dos educadores não reconhece a existência de uma cultura da criança.

Chama a atenção para o fato de que a sociedade atual está abalando a alma da criança e, com sua visão racionalista, materialista e fragmentada de si própria e do mundo, acaba por priorizar o TER no lugar do SER. Assim, "a criança é vista como algo a ser estimulado pelo adulto através de uma educação cognitivista que rapidamente deve inseri-la no sistema de produção e mercado", e, desta forma, a Cultura da Infância se torna invisível e, é evidente, que 0 brincar acaba sendo excluído da vivência das crianças. 
A criança que se encontra nos nossos currículos pedagógicos é um ser sem corpo e sem alma, classificada por ordem cronológica, colocada sobre um chão sem terra, aculturada, debaixo de um autoritarismo disfarçado em teoria do conhecimento, que determina 0 que deve ser ensinado e como deve ser ensinado, desconectado de qualquer relação significativa para a vida real das crianças. (Maria Amélia Pereira, Apostila curso Educador Brincante, 2006, p.70)

Diz que as escolas enfatizam mais as áreas cognitivas e se esquecem das áreas de expressão da criança, com uma grande ansiedade pedagógica de concluir conceitos e estruturar 0 conhecimento. Aconselha que o ideal seja "confiar mais no fato de que 0 ser humano tem dentro dele, como característica básica, a necessidade de aprender, e ao aprender, automaticamente o conhecimento se estrutura." (COUTINHO, 1996, p.7). Além disso, relata que se faz necessária a consciência de que o processo de conhecimento está sempre presente na brincadeira que está acontecendo. A criança é um aprendiz nato.

Além disso, Maria Amélia acredita que o espaço da natureza deve estar presente no processo de educação das crianças como o seu chão natural. Até 010 anos de idade, 0 espaço físico é importantíssimo para a realização de uma aprendizagem mais harmoniosa das crianças. 
Certamente, o contato direto com a natureza é o melhor lugar para as crianças articularem seus movimentos de pernas e braços com equilíbrio, fortalecendo, então, a musculatura para a estrutura óssea que se alonga a cada dia, uma vez que seu corpo encontra-se em processo de crescimento.

Confirma que, na realidade, a criança quer do adulto apenas uma escuta e um olhar mais sensível para poder se afirmar em sua essência brincante consigo mesma, com as outras crianças e com o mundo.

Maria Amélia afirma que a educação entende o lúdico de forma equivocada, pois a essência do brincar é a espontaneidade e liberdade. 0 brincar não tem objetivo pedagógico, técnico ou conceitual, ele tem um fim em si mesmo, é liberdade. "Brincar é um ato voluntário, eu me dirijo à brincadeira por um ato de decisão interna" (COUTINHO, 1996, p.8). E, se o brincar for colocado para aprender alguma coisa, imediatamente ele deixa de ser brincar, ele perde sua característica de possuir uma finalidade em si mesmo. 
Maria Amélia explica que quando a criança brinca transcende a realidade para, assim, recriar o cotidiano e é nesta esfera que prepara a fonte de criatividade do adulto.

\begin{abstract}
No brincar, o indivíduo, o espaço e possíveis objetos da brincadeira saem da esfera exclusivamente utilitária, e esta situação inclui diferentes graus de subjetividade. 0 mundo interno das crianças emprega parâmetros de uma realidade percebida que não coincidem necessariamente com as leis que governam a materialidade no objeto externo. Os efeitos externos são atenuados, e 0 objeto revela uma vitalidade mais profunda por seu valor subjetivo, pela interação imaginativa e corporal entre a criança e o objeto. Nesse justo momento há um relaxamento das defesas conscientes e se dão passos para experiências subjetivas que se encontram em níveis mais profundos, dissolvendo as divisões entre 0 que está dentro e o que está fora, comunicando a experiência do ser.

0 brincar opera nesta unidade subjetiva. 0 brincar, entendido como atitude do corpo e da mente, determina uma conduta pensante. (Maria Amélia Pereira, Apostila curso Educador Brincante, 2006, p.71)
\end{abstract}

Na ação do brincar, declara Maria Amélia, "há uma capacidade de interiorização sem esforço que sinaliza a verdadeira concentração. Neste momento 0 mundo ao redor está em total sintonia com a pessoa, há um inteiro" (COUTINHO, 1996, p 29). A criança está numa concentração tão intensa que um canal é aberto entre ela e 0 mundo, e assim ela está "vivendo o grande exercício de ligação, de estabelecimento do elo, entre ela e o seu fazer". A criança está inteira, sem fragmentação, é una. É a dimensão subjetiva operando. 
A criança que não tem espaço nem tempo para brincar está sendo privada da criação de vínculos significativos em relação à vida, porque somente aquilo que é experimentado passa realmente a ser incorporado como conhecimento.

Maria Amélia afirma que,

o brincar nasce no corpo, e o corpo é a natureza. A criança, antes do intelecto, é instinto, é sensação. Conhecer a si próprio, nesta faixa de idade, é conviver com um espaço físico que the permita experienciar no corpo os movimentos de rolar, subir, descer, correr, trepar, pular, caminhar... (Apostila curso Educador Brincante, 2006, p.72-73)

E conclui que o grande desafio da educação hoje é compreender, de fato, a língua da criança - o brincar, que na sua essência sinaliza a linguagem humana em sua verdade. É enxergar novamente 0 ser humano, voltar às raízes. "Juntar dentro de nós esses dois pólos, 0 cognitivo e o sensível. E a natureza é, na verdade, o chão que re-une os dois hemisférios cerebrais, o racional e o sensível, o lado direito e o lado esquerdo, a cabeça e o coração" (COUTINHO, 1996, p 44).

Maria Amélia luta por uma educação que possibilite à criança manifestar-se em sua inteireza, pois só assim será capaz de perceber a si própria e perceber o outro. 


\title{
1.3. A Criança e o Ambiente Urbano
}

\author{
"Quando as regras dos adultos obrigam a criança \\ a ficar passivamente olhando o seu meio ambiente, \\ proibindo-a de arranjar sua sala de aula ou \\ playground, ela provavelmente não terá \\ um papel ativo na solução dos problemas."
}

Robert Sommer

Com a crescente e desordenada urbanização das grandes cidades, a infância foi perdendo espaço onde ocorriam brincadeiras entre crianças de diversas idades que utilizavam à rua como se fossem extensões dos quintais das suas casas. Assim, a eliminação deste modo de vida comunitário das crianças nas ruas, nos quintais, nos parques e nos espaços da natureza dentro dos recreios das escolas, altera radicalmente a vida das crianças, comprometendo sua saúde física, emocional e mental.

Segundo Verden-Zöller (2004, p.194-195) o homem moderno acabou criando um mundo no qual "distorce progressivamente e de maneira extrema as condições normais para 0 
desenvolvimento da consciência humana na criança". 0 espaço da vida humana tornou-se deformado e de certa maneira destrutivo para nós, pois configura valores que negam 0 humano e acabam não proporcionando à criança o espaço de paz e liberdade que ela precisa para um desenvolvimento saudável.

Verden-Zöller alerta (2004, p.195-196) que

\begin{abstract}
Num mundo assim, sem uma relação básica com a natureza, sem liberdade de movimentos e de escolha de companheiros para brincar, não é possível desenvolver adequadamente uma consciência corporal, uma autoconsciência, uma consciência social e uma consciência de mundo.

Num mundo estranho, elas vivem alienadas de si mesmas e crescem como seres manipuláveis e socialmente alienados. Assim, desprotegidas, num ambiente que não thes proporciona confiança nem aceitação, elas jamais alcançam um desenvolvimento total de suas possibilidades humanas naturais de auto-orientação, auto-respeito, responsabilidade pessoal e social, liberdade e amor.
\end{abstract}

Já Mayumi Lima (1989), ao observar a organização dos espaços sociais das crianças em seu livro A cidade e a criança, confirma a teoria de Sommer (1973) a qual revela que uma tirania do desenho sobre o usuário, e complementa que este usuário é sempre representado quando há o coletivo, ou seja, o povo - "o trabalhador anônimo das cidades e dos campos" (1989, p.9). Suas necessidades, suas expectativas e desejos não são ouvidos, e alerta que isso acaba sendo um "processo de redução cultural, de áreas, de material..." que gera 
espaços empobrecidos, descompromissados com a qualidade e principalmente utilizados como instrumentos de dominação.

A organização e a distribuição dos espaços, a limitação dos movimentos, a nebulosidade das informações visuais e até mesmo a falta de conforto ambiental estavam e estão voltadas para a produção de adultos domesticados, obedientes e disciplinados - se possível limpos - destituídos de vontade própria e temerosos de indagações. (LIMA.1989, p.10)

Mayumi nos lembra que é no espaço físico onde a criança experimenta as primeiras sensações. É onde ela encontra os 'nutrientes' necessários para seu desenvolvimento e estabelece a relação com as pessoas e com o mundo.

\footnotetext{
0 espaço material é, pois, um pano de fundo, a moldura, sobre o qual as sensações se revelam e produzem marcas profundas que permanecem, mesmo quando as pessoas deixam de ser crianças. É através dessa qualificação que o espaço físico adquire nova condição: a de ambiente.

0 ambiente significa a fusão da atmosfera, e se define na relação que os homens estabelecem entre si, ou do homem consigo mesmo, com o espaço construído ou organizado. (LIMA.1989, p.13-14)
}

Então, defende que o espaço construído pode ser um excelente material pedagógico para as crianças. Mayumi assegura que o espaço sempre é educativo, pode promover ou mesmo 
inibir o desenvolvimento do potencial criativo, dependendo da maneira que é projetado e utilizado.

Constata que, infelizmente, o espaço escolar ainda é "frio, desinteressante, padronizado e padronizador na forma e na organização das salas, fechando as crianças para o mundo, policiando-as, disciplinando-as" (1989, p.38). E que as escolas ainda apresentam comportamento autoritário e repressivo na maneira de utilizar e organizar seus espaços; ignoram o brincar na atividade diária da criança e isso acaba por estabelecer um domínio sobre o movimento do corpo e até controle do pensamento da criança.

Há apenas dois tipos de aprendizado: um é 0 verdadeiro aprendizado e o outro é condicionamento. Condicionamento é uma resposta repleta de medo do primitivo ou o que chamamos de cérebro posterior ou cérebro reptiliano. Este é o cérebro dos reflexos, da sobrevivência, que responde como se estivesse sendo ameaçado. Aqui acontece uma forma de aprendizado, mas é um aprendizado condicionado e intimamente relacionado com estados emocionais de hostilidade, raiva e ansiedade. Se você deseja um verdadeiro aprendizado que envolva os lobos frontais superiores, o cérebro intelectual e criativo, então, mais uma vez, o ambiente emocional precisa ser positivo e de apoio. (Joseph Chilton Pearce, 1999) ${ }^{21}$

\footnotetext{
${ }^{21}$ Extraído da entrevista com Joseph Chilton Pearce, Revista Journal of Family Life, vol.5, 1999 - por Chris Mercogliano e Kim Debus. Tradução Sonia Gentil, 2003.
} 
0 ideal seria que a criança se apropriasse do espaço da escola, deixasse suas marcas ou alterasse esse espaço à sua maneira, isso serviria de estímulos para manifestar sua capacidade de desenvolvimento e transformação do seu mundo. A escola se tornaria, então, um espaço agradável e convidativo para as crianças.

É preciso pois, deixar o espaço suficientemente pensado para estimular a curiosidade e a imaginação da criança, mas incompleto o bastante para que ela se aproprie e transforme esse espaço através de sua própria ação. (LIMA.1989, p.72)

Outra pontuação diz respeito à escola que não contextualiza a criança dentro de sua comunidade, além de não permitir que ela se aproprie do espaço da sua cidade. A cidade é um espaço muito rico, com grande potencial educativo; um espaço de cultura pouquíssimo explorado pelas escolas e sem nenhuma interação com as atividades curriculares.

Para reconstruir a unidade das relações afetivas, psíquicas e cognitivas que the assegure simultaneamente a individualidade e a socialização, a crianças terão de encontrar nas novas condições urbanas aqueles espaços permeáveis onde seja possível 0 jogo e a brincadeira que envolvam os companheiros da mesma idade e observar 0 mundo dos adultos. (LIMA.1989, p.92)

Apesar desse quadro, Mayumi (1989, p 101-102) defende que a escola acaba sendo 0 único espaço real e possível para recuperação dos espaços públicos e populares, mas que 
requer a transformação na maneira de pensar "o espaço/ serviço educativo como local de propriedade coletiva e pública", além do "rompimento da escola/prisão/ fortaleza e sua transformação na escola/ praça/ parque".

Vemos que o afunilamento do espaço urbano ocorre porque há um total desconhecimento da cultura da infância, ninguém sabe o que é a criança. Na realidade, com o entendimento da existência da cultura da infância passamos a reconhecer a criança como agente transformador do espaço urbano. Ao observar as crianças, conseguiremos enxergar sua capacidade inerente de construção do seu próprio espaço, que é edificado de acordo com suas necessidades, nos seus limites e nas suas funções.

Paulo Freire (1993 apud GADOTTI, 2006 p.96-97) sempre defendeu a cidade como espaço educador:

Há um modo espontâneo, quase como se as Cidades gesticulassem ou andassem ou se movessem ou dissessem de si, falando quase como se as Cidades proclamassem feitos e fatos vividos nelas por mulheres e homens que por elas passaram, mas ficaram, um modo espontâneo, dizia eu, de as Cidades educarem. 
No início dos anos 90, no primeiro Congresso Internacional das Cidades Educadoras, em Barcelona, foi criado o conceito da "Cidade Educadora" que define os princípios básicos de uma cidade que educa. Segundo Gadotti (2006), a cidade é tida como espaço de cultura e acaba por educar a própria escola e, esta, numa troca de conhecimentos e saberes, também educa a cidade. Afirma que 0 viver na cidade já é uma aprendizagem espontânea e permanente num grande espaço cultural.

Gadotti diz que uma cidade educadora exerce além de suas funções tradicionais econômica, social, política e de prestação de serviços - ela alimenta a formação para e pela cidadania. Promove a participação "de todos, crianças, jovens, adultos e idosos - na busca de um novo direito, o direito à cidade educadora" (2006, p.97). 
0 Manifesto das Cidades Educadoras, aprovado em Barcelona, em 1990, e revisado em Bolonha, em 1994, (apud GADOTTI, 2006 p.97-98) descreve que

\begin{abstract}
A satisfação das necessidades das crianças e dos jovens, no âmbito das competências do município, pressupõe uma oferta de espaços, equipamentos e serviços adequados ao desenvolvimento social, moral e cultural, a serem partilhados com outras gerações. 0 município, no processo de tomada de decisões, deverá levar em conta 0 impacto das mesmas. A cidade oferecerá aos pais uma formação que lhes permita ajudar os seus filhos a crescer e utilizar a cidade num espírito de respeito mútuo. Todos os habitantes da cidade têm o direito de refletir e participar na criação de programas educativos e culturais, e a dispor dos instrumentos necessários que lhes permitam descobrir um projeto educativo, na estrutura e na gestão da sua cidade, nos valores que esta fomenta, na qualidade de vida que oferece, nas festas que organiza, nas campanhas que prepara, no interesse que manifeste por eles e na forma de os escutar.
\end{abstract}

Isso quer dizer que a escola é reconquistada pela comunidade, ganha nova vida se integrando na cidade, e é recuperada como novo espaço cultural se transformando "num novo território de construção da cidadania". 


\subsubsection{CEU - Centro Educacional Unificado}

A cidade de São Paulo mostrou interesse em participar do movimento das Cidades Educadoras desde meados de 2003, com a implantação dos Centros Educacionais Unificados - CEUs ${ }^{22}$. Construídos a partir de 2002, hoje a cidade conta com 45 unidades em funcionamento nas periferias de São Paulo.

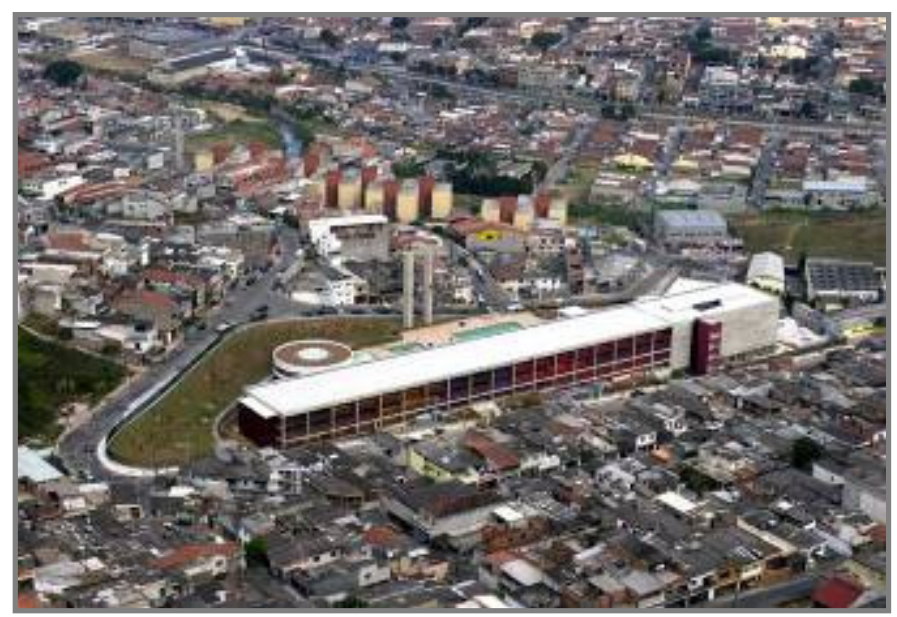

Figura 1 - CEU Rosa da China - bairro de Sapopemba. Foto: David Rego Jr.

\footnotetext{
${ }^{22}$ Ver artigo ANELLI, Renato. “Centros Educacionais Unificados: arquitetura e educação em São Paulo”. Arquitextos, n ${ }^{0} 55.02$. São Paulo, Portal Vitruvius, dez. 2004. Consultar também a revista Casabella, nº 727, Milão, novembro 2004.

E a revista ArchPlus, $n^{0} 190$, Dezembro 2008 onde Marcos L. Rosa entrevista um dos autores Alexandre Delijaicov.
} 
0 projeto possui uma visão que ultrapassa a sala de aula e o espaço escolar, estendendo para toda a cidade, com programação inclusive nos finais de semana; funciona como um equipamento urbano agregador da comunidade de periferia.
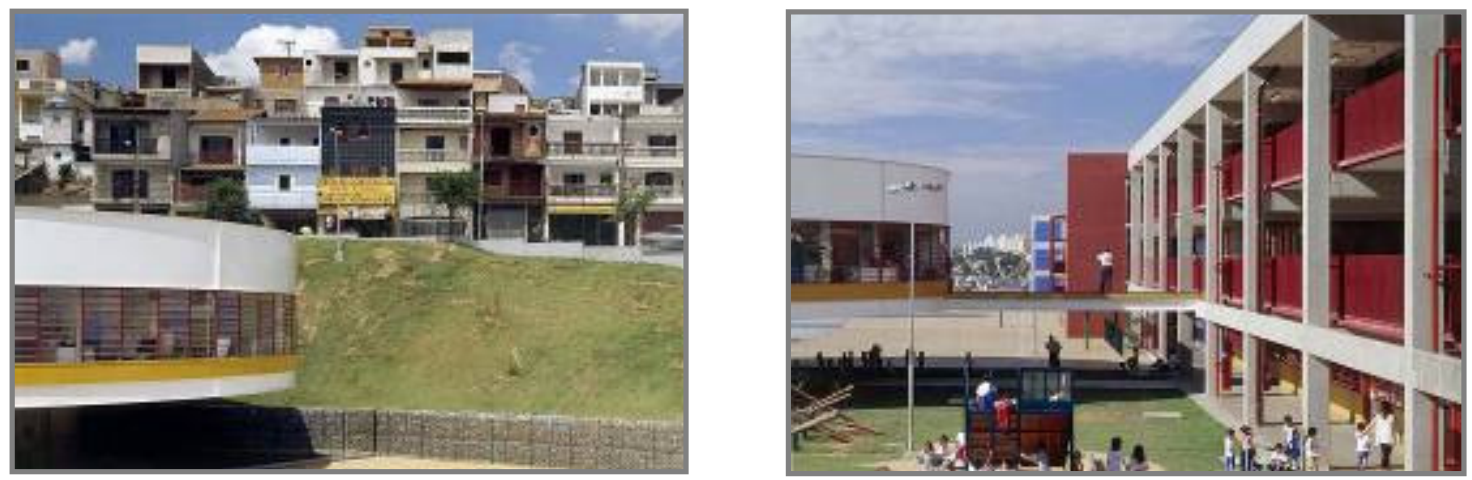

Figura 2 e 3 - CEU Rosa da China - bairro de Sapopemba. Fotos: Nelson Kon.

Projeto elaborado pela equipe de arquitetos da EDIF - Departamento de Edificações da Secretaria Municipal de Infra-estrutura Urbana e Obras da Prefeitura de São Paulo Alexandre Delijaicov, André Takya e Wanderley Ariza, é também chamado de versão contemporânea da Escola Parque ${ }^{23}$. Esta última, idealizado pelo educador Anísio Teixeira no final dos anos 40 na cidade de Salvador, e projeto arquitetônico de Diógenes Rebouças e

${ }^{23}$ Consultar: DUARTE, Hélio de Queiroz. Escola-classe escola-parque. São Paulo: FAUUSP, 1973. 
Helio Duarte. Assim, também são herdeiros do Convênio Escolar ${ }^{24}$, comissão dirigida por Helio Duarte, entre 1948 e 1952, para projetar e construir escolas-parque na cidade de São Paulo. Portanto, a história dos CEUs é mais anterior do que se imagina; remete às raízes dos ideais da Escola Nova na década de 20.

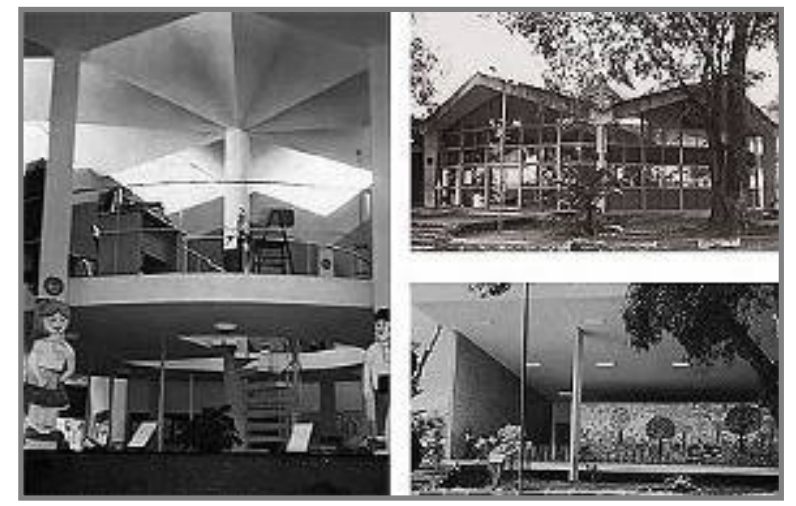

Figura 4 - Escola-parque ou Centro Educacional Carneiro Ribeiro (em duas etapas: 1947 e 1956), em Salvador, de Diógenes Rebouças. Fonte: Revista AU. n0 178, jan. 2009.

${ }^{24} 0$ Convênio Escolar (1948-1952) foi uma ação política entre os governos do Município e do Estado de São Paulo para a construção em massa de escolas para atender o déficit monstruoso de vagas escolares. 0 diretor de Planejamento da Comissão Executiva do Convênio Escolar foi o arquiteto Helio Duarte, que utilizou a experiência obtida com implantação da Escola Parque em Salvador. 
Além disso, na ocasião da formação da EDIF, o educador Paulo Freire era secretário municipal de educação ${ }^{25}$, e, a partir desse momento, inicia-se a idéia de utilizar 0 edifício público como elemento estruturador da cidade, ou seja, começa a se pensar nos Centros Educacionais Unificados implantados nas periferias de São Paulo.

Os complexos educacionais possuem creche, Escola de Educação Infantil, Escola de Ensino Fundamental, playground, centro comunitário, teatro, cinema, biblioteca, quadras esportivas, ateliês, parque aquático, estúdios para oficinas de vídeo, TV, rádio e fotografia, telecentro e pista de skate, permeados por grandes áreas verdes.
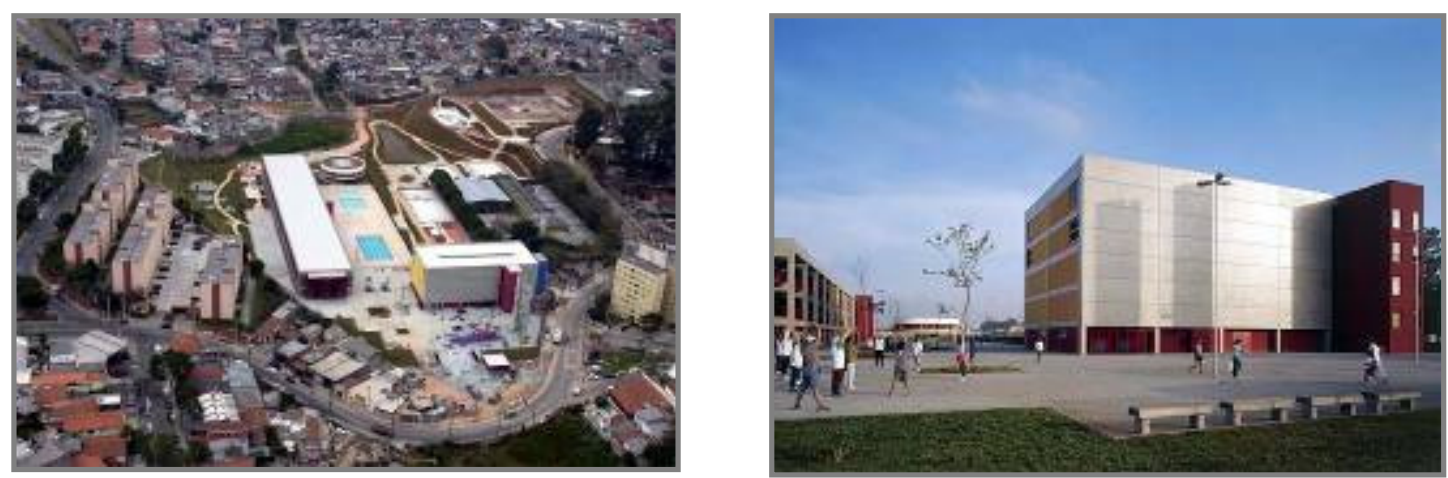

Figura 5 e 6 - CEU Butantã Fotos: David Rego Jr. e Nelson Kon.

${ }^{25}$ No período de 01 de janeiro de 1989 a 27 maio de 1991, na gestão da prefeita Luiza Erundina. 
Além da implantação dos próprios equipamentos, o entorno também é contemplado com a reestruturação viária e saneamento básico para prover a periferia paulistana de um novo desenho urbano.

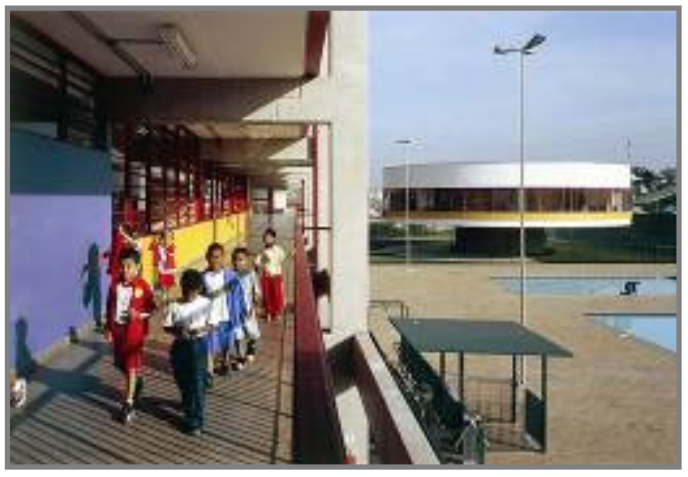

Figura 7 - CEU Butantã. Foto: Nelson Kon

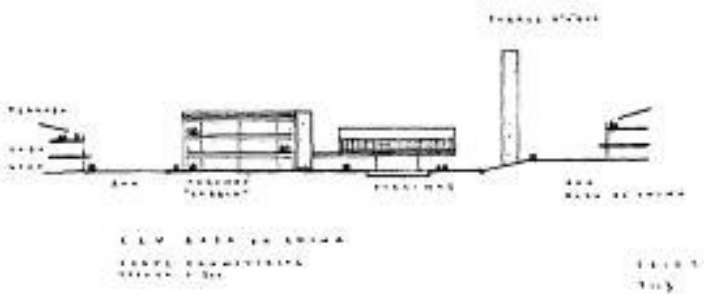

Figura 8 - Croqui CEU Rosa da China.

[...] 0 projeto... Agrupa 0 programa em três conjuntos volumétricos de formas simples e despojadas. 0 maior em forma de grelha ortogonal reúne as salas de aula, refeitórios, biblioteca, programa de inclusão digital, padaria-escola, áreas para exposições e para convivência. 0 menor, em forma de disco elevado do solo abriga a creche. 0 terceiro reúne em um paralelepípedo de cinco andares, teatro, ginásio esportivo e sala de ensaios musicais. (ANELLI, 2004, p.2) 26 $^{26}$

\footnotetext{
${ }^{26}$ Trecho extraído do artigo ANELLI, Renato. "Centros Educacionais Unificados: arquitetura e educação em São Paulo". Arquitextos, $\mathrm{n}^{0}$ 55.02. São Paulo, Portal Vitruvius, dez. 2004.
} 
Foi desenvolvido um projeto básico padrão em sistemas pré-moldados para adaptar-se a variados tipos de terreno e ainda dialogar com diversos contextos. Os espaços livres disponíveis na cidade para a implantação das Praças de Equipamentos - como os autores preferem chamar os CEUs - geralmente são áreas às margens de rios, várzeas ou de nascentes, protegidas pela legislação ambiental. Para solucionar essa problemática, os arquitetos incorporaram o leito fluvial ao desenho urbano das periferias, transformando as antigas áreas degradadas em belíssimos parques fluviais. ${ }^{27}$

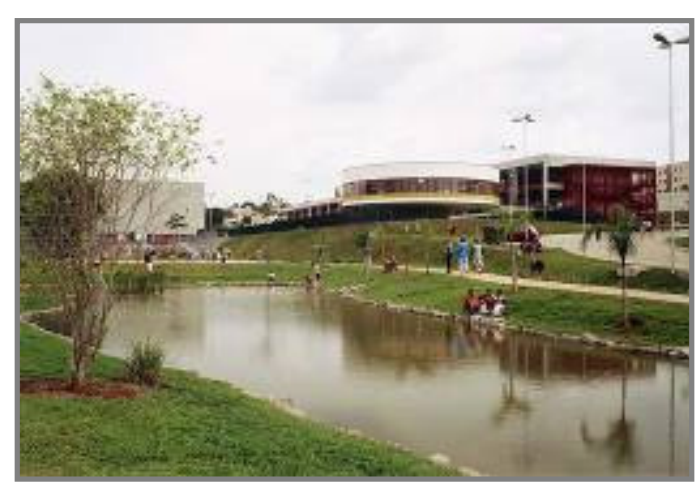

Figura 9 - CEU Butantã. Foto: Nelson Kon.

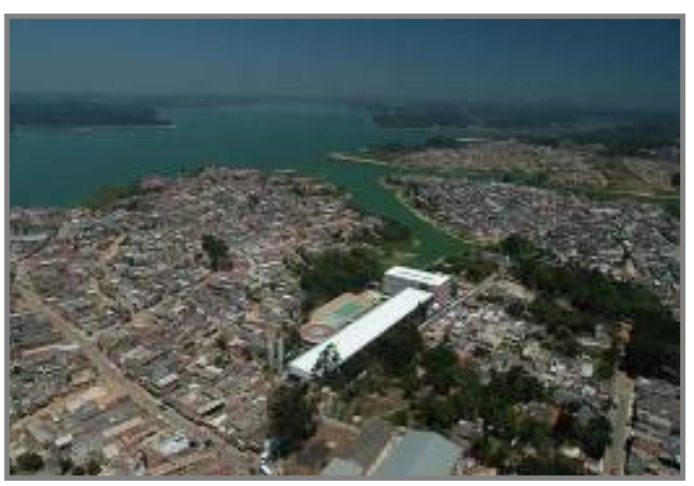

Figura 10 - CEU Navegantes - parque residencial Cocaia/ Grajaú. Foto: David Rego Jr.

\footnotetext{
${ }^{27}$ Vale a pena conferir a dissertação de mestrado: DELIJAICOV, Alexandre. "Os rios e o desenho urbano da cidade. Proposta de projeto para a orla fluvial da Grande São Paulo". FAU USP, 1998.
} 
[...] reproduzem em contextos diversos os elementos construtivos e distributivos amplamente aprovados pelo tempo, e acrescentam a eles uma nova atenção aos espaços abertos. É espantosa a naturalidade com a qual os protótipos e os modelos da primeira revolução moderna são repropostos no novo século, como se o tempo não tivesse passado. A seriedade da relação com a comunidade dos usuários age como freio intelectual contra toda divagação (BENEVOLO, 2007, p.409)

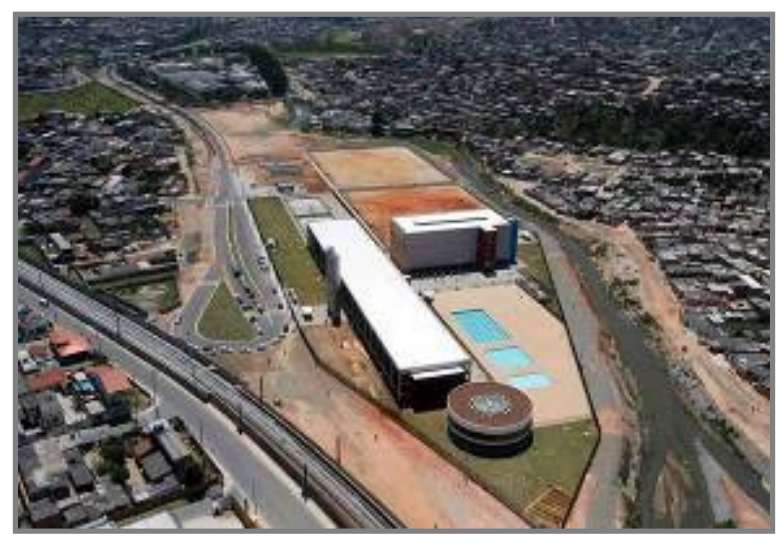

Figura 11 - CEU Jambeiro - bairro Guaianazes.

Foto: David Rego Jr.

Figura 12 - CEU Perus. Foto: David Rego Jr.

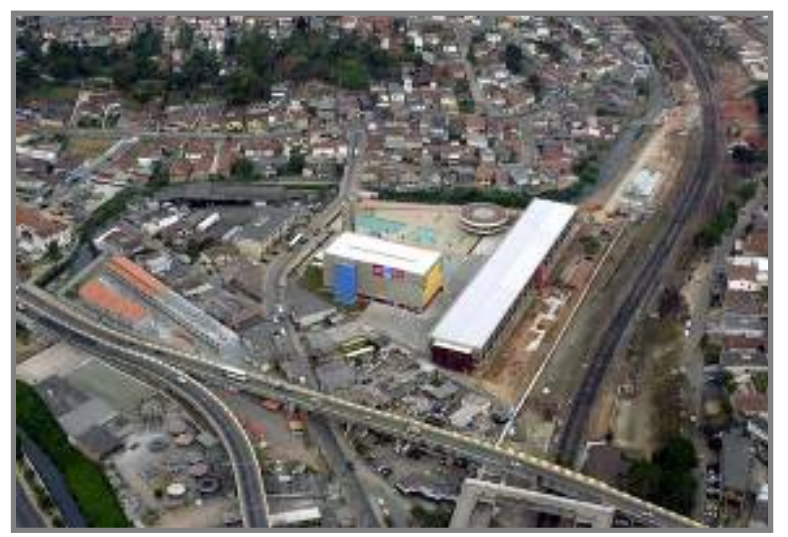


Vale ressaltar os principais ideais que permearam as atividades dos arquitetos da EDIF: a busca constante pela construção do projeto coletivo, a valorização dos espaços públicos da cidade, 0 edifício público como estruturador do desenho urbano, o reconhecimento da arquitetura pública como uma cultura artística, entre outros não menos importantes. E, para espanto, no início de 2009, a prefeitura de São Paulo iniciou o processo de desarticulação da EDIF com 0 afastamento dos arquitetos Alexandre Delijaicov e André Takya de seus cargos, de maneira a romper a linha contínua de ação projetual que esses arquitetos tanto lutaram. 


\section{A IDENTIDADE DA ALDEIA DE CARAPICUÍBA}




\section{A IDENTIDADE DA ALDEIA DE CARAPICUÍBA}

\subsection{Processo de colonização no Planalto Paulistano e os Aldeamentos Paulistas}

Para compreender a origem e a formação da Aldeia de Carapicuíba, precisamos nos atentar à história da colonização brasileira, mais precisamente à história da formação da região do Planalto Paulistano.

Petrone (1995, p.13) classifica Campos de Piratininga como Bacia Terceária que apresentava função de "core" de grande parte do Sudeste brasileiro. Suas terras já tinham sido valorizadas e parcialmente aproveitadas pela ocupação pré-cabralina, portanto, os colonos europeus

[...] já não encontraram quadros naturais intactos, mas parcialmente modificados. É frente a esses quadros que os referidos colonos reagiram com novo processo, dessa vez, entretanto, aproveitando, direta ou indiretamente, a experiência ameríndia expressa por seu intermédio. 
E a presença dos indígenas foi fundamental para solidificar a organização econômica e criar bases para seu povoamento. Assim, em São Paulo e arredores a instituição de cativeiros, 0 apresamento e administração do indígena foi regra para reunir grande contingente ameríndio, formando os aldeamentos, de suma importância para a defesa e sobrevivência do Planalto Paulistano.

Quanto à população indígena que já habitava a região, resumidamente os grupos mais significativos foram os Tupinambá, Tupiniquim e os Carijó, sendo que os dois últimos dominariam o interior. Já o Tupiniquim teve contato mais intenso com os europeus e são considerados tradicionalmente como Guaianá. Todos esses grupos são de idioma tupiguarani.

A ocupação se deu em amplas áreas, porém com densidades populacionais relativamente baixas e basicamente suas atividades de subsistência eram a agricultura, caça, pesca e coleta. 


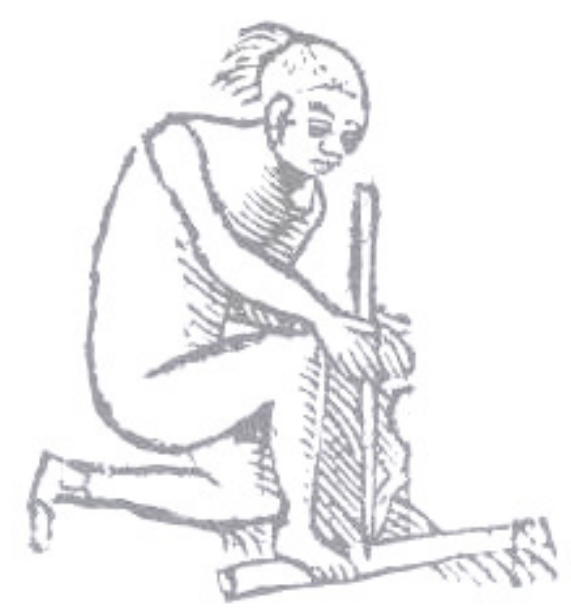

Figura 13 - 0 índio. Fonte: Hans Staden, sec. XVI, 1999, p.9.

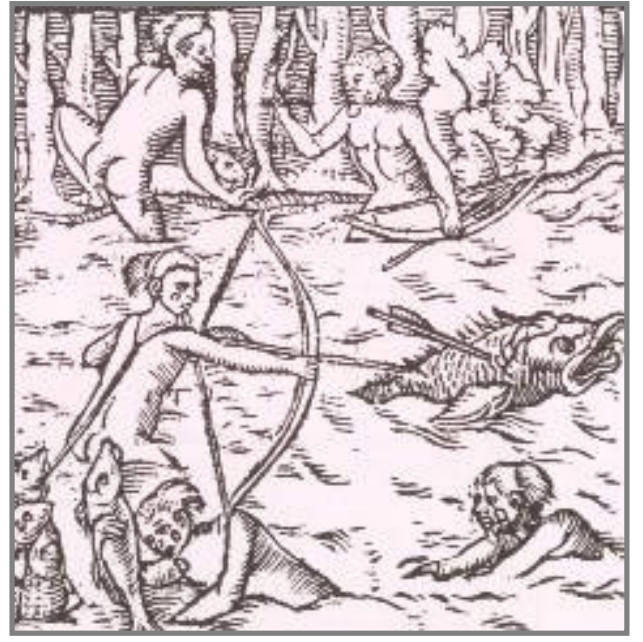

Figura 14 - A pesca. Fonte: Hans Staden , sec. XVI,1999, p.94.

Outra característica forte dos grupos indígenas mostrava-se na mobilidade, não só devido ao nomadismo, porém principalmente focado na movimentação dentro da própria área de subsistência, obedecendo a ciclos.

Na época do inverno, por exemplo, ocorria o deslocamento de grupos inteiros para o mar, já que a pesca era praticada não somente nos rios, mas também a beira-mar. Portanto a faixa litorânea tinha função de zona periférica, enquanto que o planalto era a região escolhida para a fixação, ilustrando a função de "core", objeto de interesse dos colonizadores e também dos catequizadores jesuítas. 
[...] Mas a influencia dos jesuítas não se resumiu apenas na introdução de um sistema planificado de localização, distribuindo os assentos segundo critérios previdentes e seguros. Avançou também no que concerne a posição das aldeias em relação com a vizinhança. Na beira do rio ou córrego a aldeia missionária prefere sempre um alto, a cavaleiro de vastas extensões abertas ao olhar prevenido do jesuíta. E também obedecendo às disposições das Leias das Índias [...] SAIA, 1938.

“As intensas relações que em época pré-colombiana já se verificavam entre o planalto e 0 litoral vêem-se comprovadas pelas numerosas trilhas que atravessavam o obstáculo da Serra do Mar." (PETRONE, 1995, p.33).

0 caminho mais conhecido e importante é chamado de Peabiru ${ }^{28}$, e pelos jesuítas por caminho de São Tomé. Mas “[...] não devem, entretanto, ser considerados como vias de penetração, dinamicamente servindo a grupos litorâneos. Tudo leva a indicar que se trataria do contrário".

\footnotetext{
${ }^{28}$ Os Peabirus (na língua tupi, "pe" - caminho; "abiru" - gramado amassado) são antigos caminhos, utilizados pelos indígenas sulamericanos desde muito antes do descobrimento pelos europeus, ligando o litoral ao interior do continente. A designação Caminho do Peabiru foi empregada pela primeira vez pelo jesuíta Pedro Lozano em sua obra "História da Conquista do Paraguai, Rio da Prata e Tucumán", no início do século XVIII.

0 principal destes caminhos, denominado como Caminho do Peabiru, constituía-se numa via que ligava os Andes ao Oceano Atlântico, mais precisamente Cusco, no Peru, à altura do litoral da Capitania de São Vicente (atual estado de São Paulo), estendendo-se por cerca de três mil quilômetros, atravessando os territórios dos atuais Peru, Bolívia, Paraguai e Brasil.

Em território brasileiro, um de seus troços ou ramais era a chamada Trilha dos Tupiniquins, no litoral de São Vicente; outro partia de Cananéia; troços adicionais partiam do litoral dos atuais estados de Santa Catarina e do Rio Grande do Sul.
} 
A valorização das terras dos Campos de Piratininga levou a região a tornar-se, segundo Petrone (1995, p.40) "o primeiro núcleo estável de povoamento europeu no interior do Brasil."

Os jesuítas consideravam os Campos de Piratininga como região estratégica que facilitaria a penetração para 0 interior, tinham como objetivo a conquista e catequização dos povos da chamada mesopotâmia paraguaia, local de grande concentração demográfica.

Assim, o Planalto Paulistano que antes era "core" do povoamento indígena viria a ser também "core" da capitania de São Vicente, função que perdura até os dias de hoje. Com a Serra do Mar, obrigou-se a ter um único caminho entre o porto marítimo e o interior, fazendo com que a região tomasse posto de "porto seco", favorecendo ainda mais a posição de centro. 


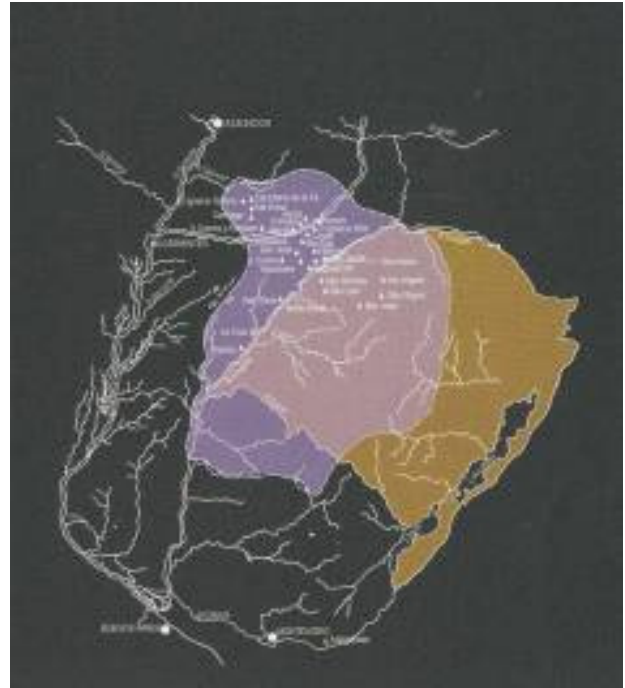

Figura 15 - Missões Jesuítas de Guaranis - 1750 - Fonte: COMAS, Carlos Eduardo. "Lucio Costa e as missões: um museu em São Miguel”, 2007,

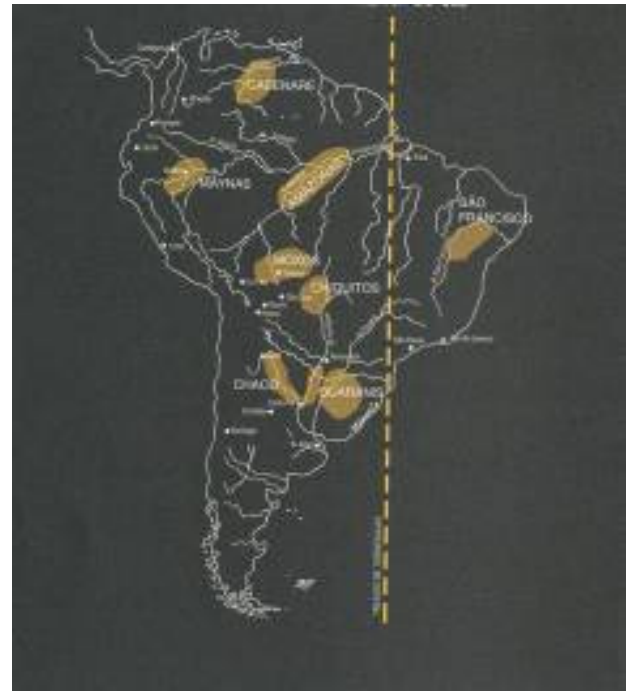

Figura 16 - Missões Jesuítas na América do Sul - Fonte: COMAS, Carlos Eduardo. "Lucio Costa e as missões: um museu em São Miguel”, 2007,

No Quinhentos, diversos núcleos surgiram na região dos Campos de Piratininga, "além de Santo André da Borba do Campo, de duração curta, e de São Paulo de Piratininga... Conheceram o enquadramento de inúmeras aldeias indígenas, além da criação de novos aldeamentos"(PETRONE, 1995, p.46). Esses núcleos, a princípio, surgiram com o objetivo de defesa, mas ao longo do processo tiveram o papel principal de fornecimento de mão-deobra. 


\subsubsection{Os Aldeamentos Paulistas}

Aroldo de Azevedo diferencia a expressão aldeia de aldeamentos. Segundo ele, aldeia são os aglomerados espontâneos, os núcleos indígenas, as tabas; já aldeamento significa núcleo criado conscientemente, "com 0 objetivo de abrigar uma população indígena em fase de assimilação" (PETRONE,1995, p.105). Assim, pode-se afirmar que os aldeamentos foram um dos principais instrumentos do processo de colonização.

Como já foi verificado, os primeiros exploradores europeus puderam aproveitar a experiência dos povos pré-cabralinos, e, é claro, que muitas dessas antigas aldeias se transformaram em aldeamentos.

A dispersão era a característica principal na organização espacial dos assentamentos, além do uso dos índios como mercadoria, e, também, sobretudo como frente de trabalho escravo. A vida dos colonos era essencialmente rural e baseado na auto-suficiência. 
[...] Os fatos que interessam a criação da primeira vila brasileira são significativos. A preocupação de Martim Afonso foi a de demarcar sua área e promover arruamento, levantar um forte, a casa da Câmara, cadeia, igreja e fornecer-Ihe um edifício administrativo. Ao mesmo tempo, porém, iniciou a distribuição de sesmarias, promovendo a introdução de plantas e animais para dar início às atividades agropastoris. (PETRONE, 1995, p.55)

Um dos fundamentais responsáveis pela origem dos aldeamentos, os padres jesuítas da Companhia de Jesus, por meio de sua ação catequizadora, criaram base sólida para a implantação e permanência dos índios aldeados nos núcleos.

0 Regime das Missões, orientados pelos padres Anchieta e Nóbrega, iniciou-se no governo Mem de Sá.

Na configuração dos aldeamentos ${ }^{29}$, o centro é sempre a Igreja e o primeiro edifício a ser erguido, numa posição de predominância mais elevada que o restante do núcleo. 0 Largo da Igreja, além de ser o centro religioso, é também o administrativo e social e quase sempre definido na forma retangular ou quadrado perfeito. Nessa ocasião, pode-se dizer com rígida geometria, baseada nas Leis das Índias, um pátio quase fechado em si.

${ }^{29}$ Ver texto, páginas 99 a 101 deste trabalho sobre as diversas configurações dos aldeamentos. 
[...] em síntese, os elementos principais do núcleo central de qualquer aldeamento foram os seguintes: no centro da praça, quadrado ou retangular, verdadeiro terreiro, abrigando um cruzeiro e o tronco. Numa das faces da praça, em geral ocupando um dos cantos, a igreja dominava o conjunto, fato que pode ser percebido ainda em Embu, Escada, Carapicuíba e Barueri... Ao lado da igreja, em geral formando um só bloco de modo a ocupar toda uma face da praça, aparecia a residência para um ou mais religiosos. (PETRONE,1995, p.231)

\section{Luis Saia, em seu estudo de 1937 sobre a Aldeia de Carapicuíba ${ }^{30}$, afirma}

[...] Não estaria aí mais do que a racionalização de formas mais ou menos quadrangulares que surgiam freqüentemente na Europa. 0 quadrilátero bem projetado, de ângulos retos, desobediente muitas vezes a topografia local, tem mesmo bastante sabor jesuítico. Principalmente sabor de fórmula, de estandartização. Não era a primeira vez que uma terra conquistada recebia assim um sistema organizado de estrutura das cidades.

Figura 17 - Aldeia Jesuíta, projeto de acordo com as Leis das Índias - Fonte: SAIA, 2005, n.16.

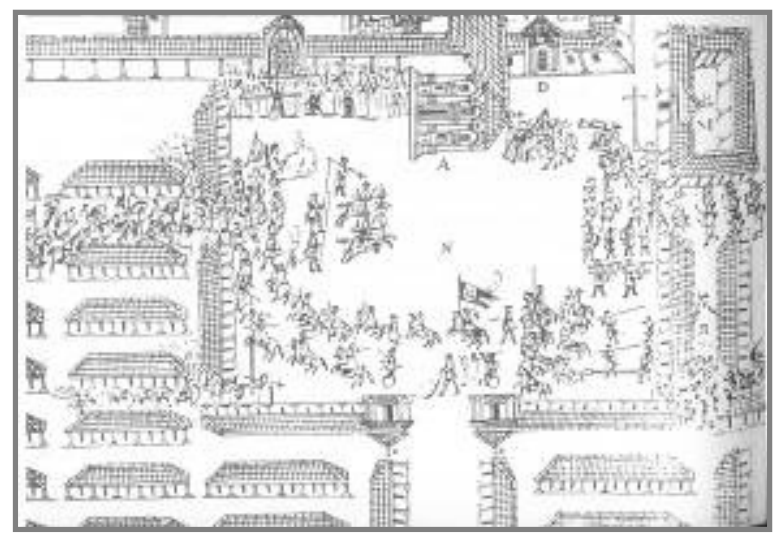

\footnotetext{
${ }^{30}$ Trabalho não publicado e, segundo o próprio Saia, com algumas informações equivocadas. Em seu livro A morada paulista 1995 (p.20) relata: "Em 1937, quando auxiliar de Mario de Andrade e candidato à chefia regional do então Serviço do PHAN, a fim de suprir a falha de não ser ainda arquiteto diplomado, realizei um estudo sistemático da aldeia de Carapicuíba. Trabalho exaustivo e cheio de erros - éramos tão inocentemente ignorantes em matéria de arquitetura tradicional que nem sabíamos o que não sabíamos - de observação e de visão global. Tal trabalho, embora imaturo, levantara alguns problemas fundamentais que não foram posteriormente questionados pelas observações feitas durante as obras. No limite, pois, do que está dito neste capítulo, tudo foi razoavelmente confirmado. Nunca publiquei nem publicarei tal estudo, o qual tem estado à disposição dos estudiosos na sede do $4^{0}$ Distrito. E tem sido usado não poucas vezes".
} 
Assim, a praça constituída e considerada uma síntese do aldeamento, expressava "0 caráter de comunidade próprio desses núcleos". E pode-se dizer que as habitações eram simples abrigos, construídas com materiais de pouquíssima durabilidade e sem qualquer comodidade para os moradores aldeados; de pau-a-pique e cobertas de sapé. ${ }^{31}$

Apesar de Saia (1937) afirmar que há um partido racional por trás do traçado geométrico nas implantações dos aldeamentos (Leis das Índias), também assume que há traços primitivos ao desenvolver uma comunidade ao redor de um terreiro; "aliás, o fato mesmo de a cidade ou vila se desenvolver em torno de uma área não é especificamente europeu. É antes primitivo e universal”. Cita, ainda, as gravuras de Hans Staden, do século XVI.

Petrone (1995, p.229) afirma que "[...] repete nos quadros especiais dos aldeamentos, alguma coisa da ocara indígena, em tênue casamento com o fórum ou a ágora, ou com a piazza itálica". Até mesmo diz que Aroldo Azevedo relaciona o largo retangular a certos tipos de ocaras do Tupi quinhentista (PETRONE, 1995, p. 230).

${ }^{31}$ As características e configurações das habitações estão contidas na compilação parcial do texto de Luis Saia no anexo. 


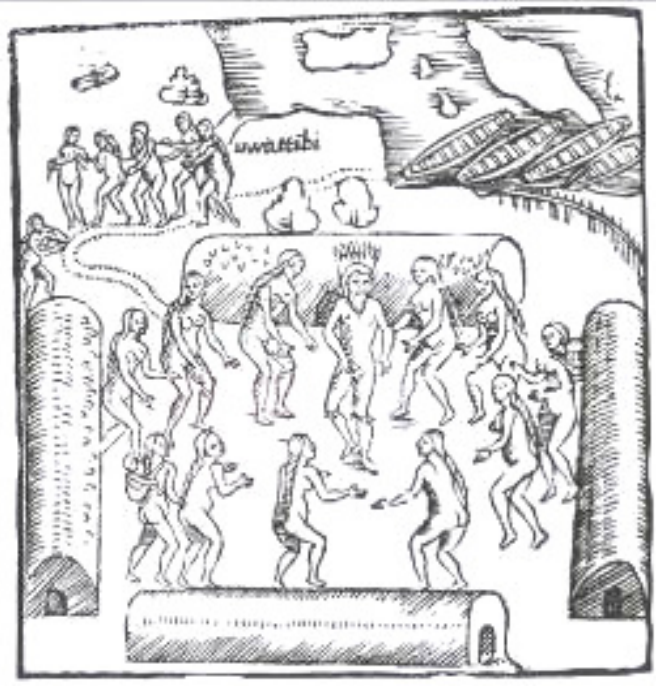

Figura 18 - Dança das mulheres ao redor de Hans Staden , em Ubatuba. Fonte: Hans Staden, sec. XVI, 1999, p.58.

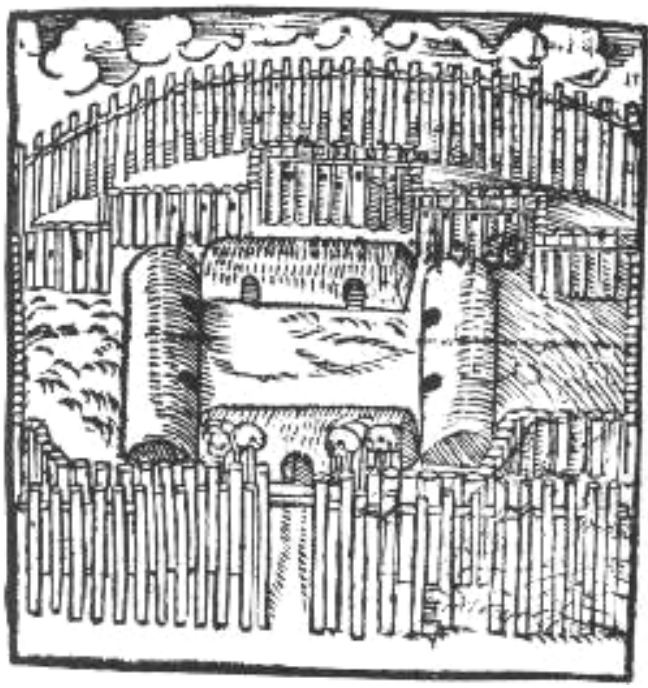

Figura 19 - Aldeia fortificada por estacas.

Fonte: Hans Staden , sec. XVI, 1999, p.92. 
Segundo 0 estudo de Weimer (2005, p.46) a forma mais comum de assentamentos indígenas são as aldeias formadas por várias construções. A cultura que mais adotou esse tipo de solução é a tupi-guarani, sendo que algumas dessas aldeias eram configuradas por oito casas ordenadas, duas a duas, nos lados do quadrado formado pelo pátio central. Assim, as quatro casas-grandes formavam a praça central, espaço uno da tribo onde aconteciam as cerimônias e outras atividades importantes da aldeia.

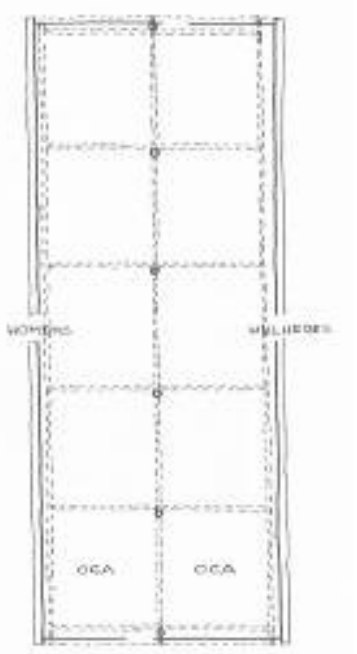

[...] Essas formas de aldeias ainda hoje podem ser encontradas na Amazônia e em pouco divergem de uma forma comum que é a existência de quatro construções, ortogonais entre si e ordenadas de modo que formem uma grande praça quadrada em si. Cada uma dessas casas é chamada de oguassu, maioca ou maloca (casa grande) e é dividida internamente pela estrutura do telhado em espaços quadrados de aproximadamente 6 por 6 metros onde mora uma família celular. Esse espaço é denominado oca (tupi) ou oga (guarani). 0 tamanho de cada casa grande depende do tamanho da tribo, podendo chegar a mais de 200 metros de comprimento. 0 mais comum é que não passem de 150 metros de comprimento por cerca de 12 metros de largura [...]. Weimer, 2005

Figura 20 - Planta da maioca tupi-guarani.

Fonte: Weimer, 2005, p.47. 
Weimer (2005, p.68-69) também diz que a formação de vilas foi uma das influências indígenas. Segundo consta, vem do mito tupi-guarani mirá - a terra sem males. E a busca por essa terra gerou grandes movimentos migratórios de tribos do interior em direção ao sol nascente. Porém, ao chegar ao Atlântico, a peregrinação era bloqueada e acabavam se fixando nessas regiões.

E logo que os jesuítas encontravam um aldeamento, iniciavam a catequese e, para simbolizar o ato, um cruzeiro no centro do terreiro (ocara) era construído. Em seguida, vinha a construção de uma capela em frente à cruz ou no lugar de alguma casa. Portanto, a capela ocupava sozinha um dos lados do terreiro ou junto de outras construções de apoio geralmente num nível mais elevado.

A Aldeia de Carapicuíba é um exemplo da implantação da igreja no alinhamento de casas indígenas. 
Figura 21 - Implantação da Aldeia de Carapicuíba em 1937. Fonte: Weimer, 2005, p.70.

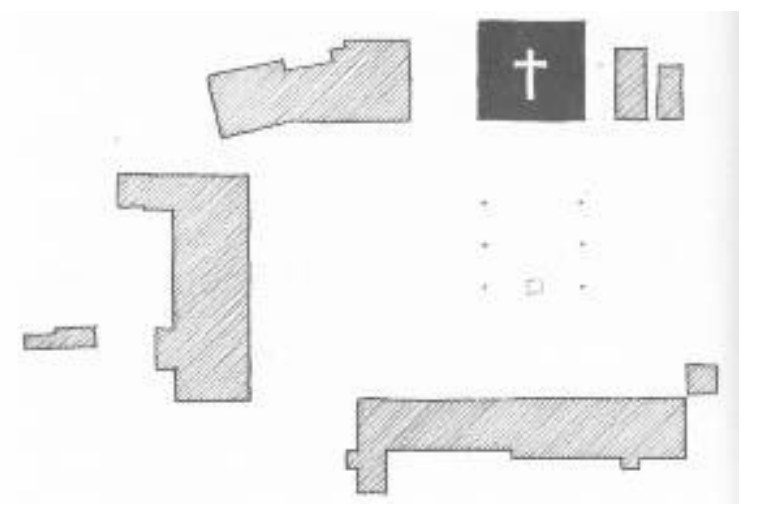

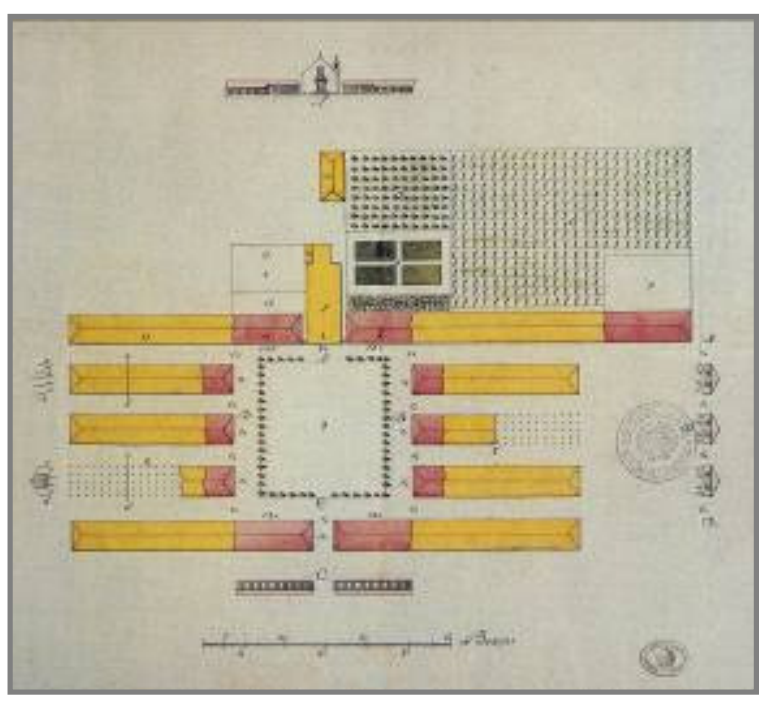

Figura 22 - Igreja no alinhamento das casas indígenas, igual a Carapicuíba, Aldeia Maria de Caiapó, Goiás . Fonte: REIS, Nestor Goulart . 2000, p.242.

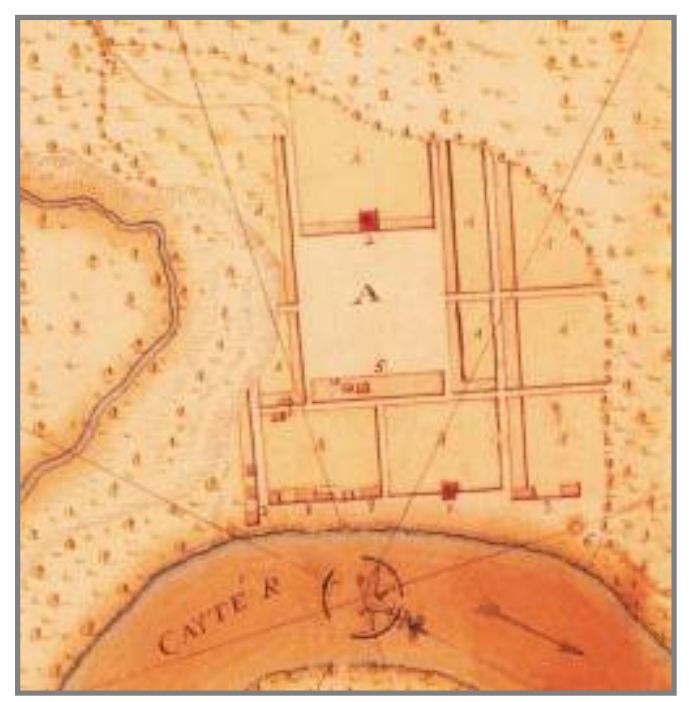

Figura 23 - Outro exemplo da igreja no alinhamento das casas indígenas, Villa Nova de Bragança, Pará. Fonte: REIS, Nestor Goulart . 2000, p.280. 
Figura 24 - Implantação da igreja isolada em uma das faces o terreiro, Villa de Jacareí, São Paulo Fonte: REIS, Nestor Goulart . 2000, p.207.

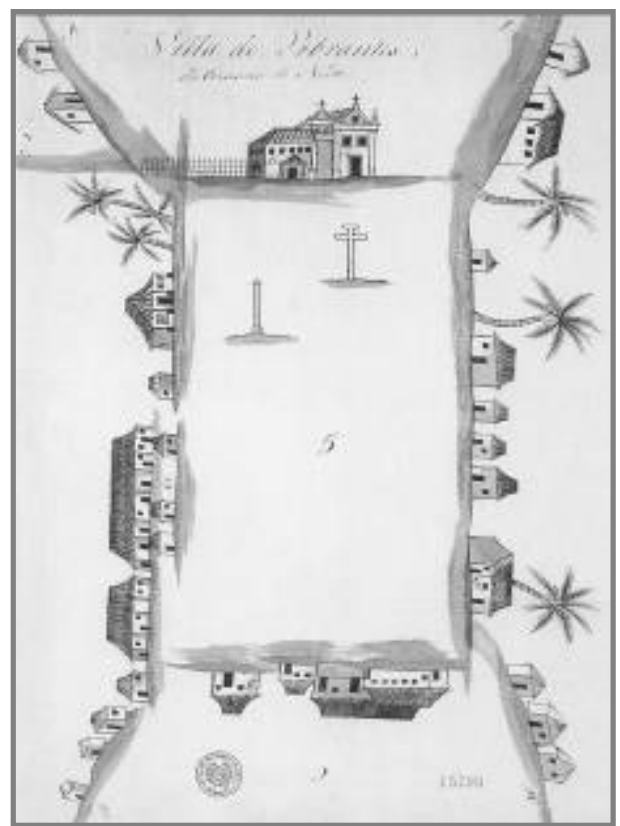

Figura 25 -Outro exemplo da igreja isolada em uma das faces da ocara, Villa de Abrantes, Bahia . Fonte: REIS, Nestor Goulart . 2000, p.63.
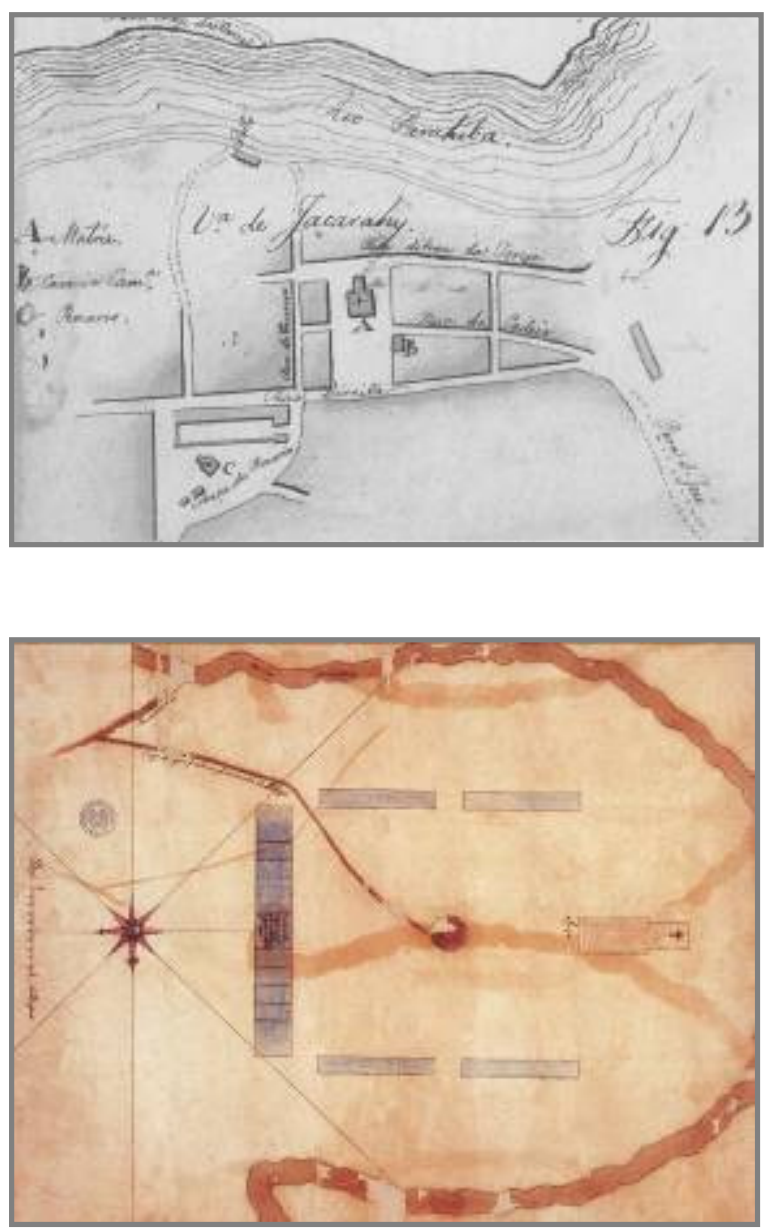

Figura 26 - Implantação Aldeia de Santa Ana Igreja isolada, Goiás . Fonte: REIS, Nestor Goulart . 2000, p.243. 


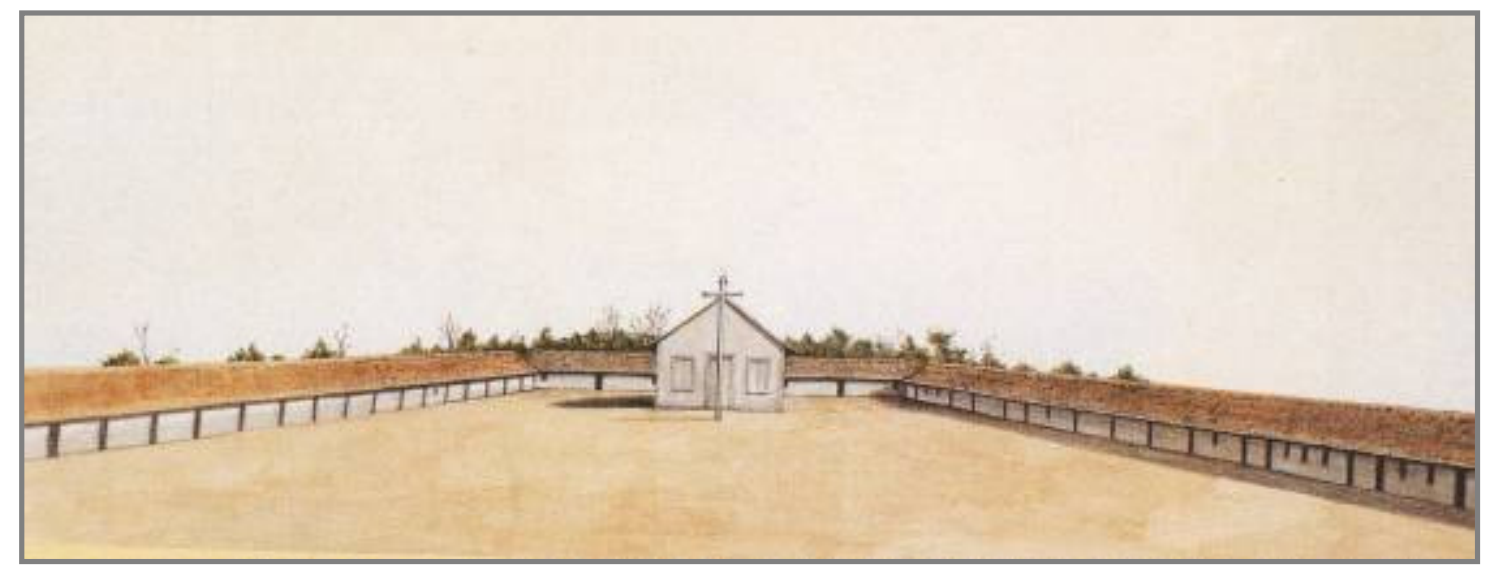

Figura 27 - Igreja no centro da ocara - Povoação de Albuquerque, Mato Grosso do Sul . Fonte: REIS, Nestor Goulart . 2000, p.248.

Figura 28 - Outro exemplo de implantação da igreja no centro da ocara - Villa de N. S. da Ajuda de Jaguaripe . Bahia. Fonte: REIS, Nestor Goulart . 2000, p.54.

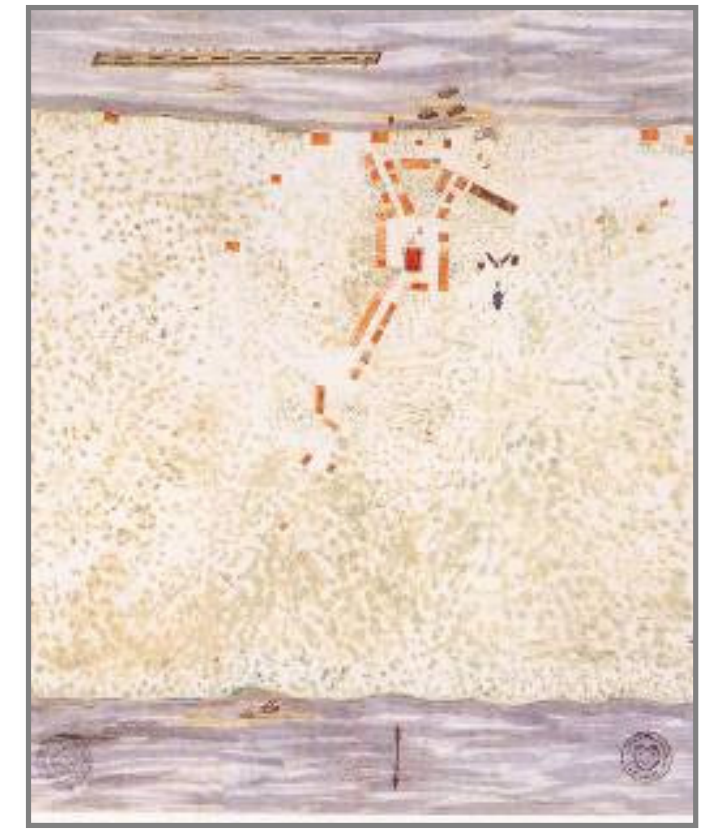


Aldeamentos - da administraçao à extinção

A partir do início século XVII, com a implantação da Lei de 1611 que pela primeira vez estabelecia normas para a criação dos aldeamentos, as aldeias foram distinguidas em fazendas dos jesuítas e aldeias do Padroado Real, diferenciando o tipo de administração a que estavam sujeitas.

As fazendas jesuítas tinham como característica principal a estabilidade, garantida pelas normas 'rígidas' dos inacianos. Já as aldeias do Padroado Real eram administradas pela Capitania com suas normas voltadas exclusivamente aos interesses dos exploradores e da Coroa.

Mas em 1640, os jesuítas foram expulsos pelos paulistas, acarretando crise e decadência dos aldeamentos jesuíticos, em um curto período de tempo; até 1653. Com o retorno dos padres da Companhia de Jesus, a estabilidade estava garantida em suas 'fazendas', porém, não puderam fazer mais nenhuma intervenção nas aldeias do Padroado Real, ficando essas a beira do esgotamento. 
Essa fase durou até 1698 quando foi instaurado o primeiro regimento para aldeamentos sujeitos à Camara, que basicamente pregava: a importância da presença de um pároco; normas para recrutamento do trabalho indígena e direito dos indígenas às suas terras. 0 governo dos aldeamentos foi atribuído aos administradores-gerais ou procuradores-gerais, ficando ao pároco somente a liderança espiritual.

Assim, no início do século XVIII, a prosperidade e estabilidade voltava aos aldeamentos devido à ação dos administradores-gerais mas,

\begin{abstract}
0 período de estabilidade foi muito breve. Logo os aldeamentos conheceram novo processo de decadência, de novo voltaram a se despovoar, dado o fato de os indígenas serem utilizados para toda sorte de serviços, muitíssimos sendo solicitados para as entradas nos sertões, a maioria permanecendo nas minas ou falecendo nas expedições. (PETRONE 1995, p.187)
\end{abstract}

Petrone (1995, p.189) mostra que a situação estava tão insatisfatória que chegou a ponto de a administração de alguns aldeamentos do Padroado Real ser passada a "religiosos franciscanos (Peruíbe, Escada e São Miguel), beneditinos (Pinheiros) e carmelitas (Barueri)”, ação que apenas favoreceu para que não desaparecessem de uma vez. 
No entanto, neste mesmo período, os aldeamentos dos jesuítas apresentavam melhores condições: algumas aldeias construíram igrejas, como Embu (1740) e Carapicuíba (1736).

Em seguida, vem a fase do Diretório (fim do século XVIII) delineada pela expulsão definitiva dos jesuítas de todos os aldeamentos, deixando-os na mesma situação miserável dos aldeamentos do Padroado; e também pela ação de Morgado Mateus na tentativa de fortalecer as aldeias queria "reorganizar os quadros do habitat".

As providências tomadas por Morgado Mateus chegaram a criar certa estabilidade, entretanto não conseguiram incentivar o desenvolvimento. 0 que ocorreu, na realidade, é que os aldeamentos já não despertavam mais 0 interesse da administração e isso facilitou a miserabilidade das mesmas.

Diante dessa situação, o governador Castro e Mendonça, em 1798, encarregou José Arouche de Toledo Rendon para visitar todos os aldeamentos a fim de elaborar um relatório sério sobre suas condições. A partir desse relatório, foi criado um plano que basicamente destacava que a única maneira de salvar e incentivar o desenvolvimento dos aldeamentos 
seria possível com a retirada dos indígenas, além da criação de freguesias nas áreas dos antigos aldeamentos. 0 plano foi executado parcialmente, mas, mesmo assim, consumavase a extinção dos aldeamentos. 
Os doze aldeamentos mais significativos foram: Pinheiros, São Miguel, Barueri, Carapicuíba, Guarulhos, Embu, Escada, Itaquaquecetuba, Itapecerica, São José, Peruíbe e Queluz, este último, apesar de ter história recente, possui características diferenciadas.

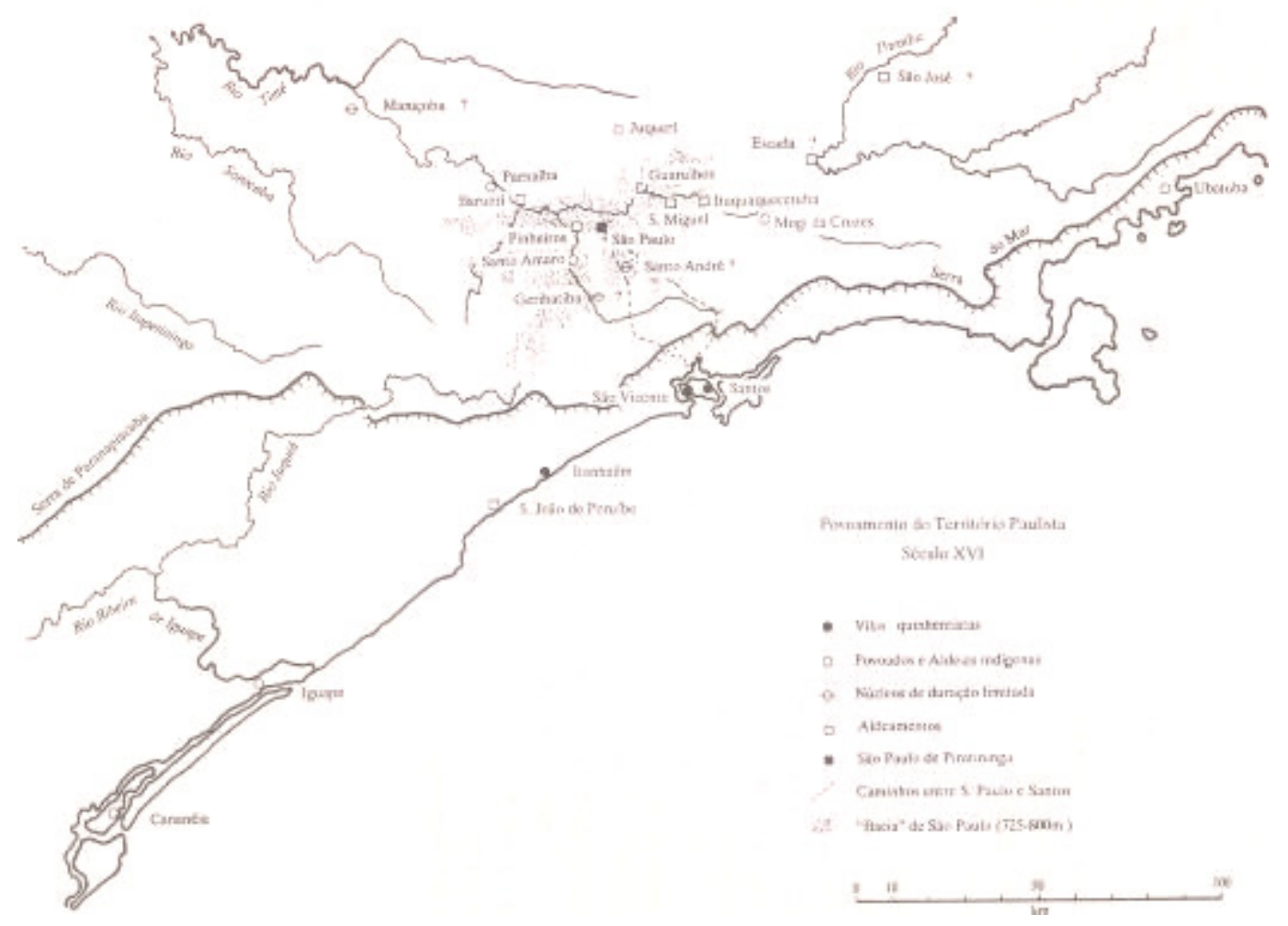

Figura 29 - Mapa dos aldeamento Paulistas . Fonte: Petrone, 1995, p.47. 
Segundo consta, a primeira tentativa de aldear os índios foi em um ponto longe de São Paulo de Piratininga - Maniçoba - núcleo de duração limitada e imprecisa, que surgiu devido à presença do caminho indígena Peabiru.

Pinheiros e São Miguel foram os primeiros aldeamentos organizados pelos jesuítas a tomar forma num período em que o território do Planalto Paulistano era caracterizado pela insegurança e instabilidade, revelados nos combates entre colonos e indígenas. Peruíbe foi 0 único núcleo entre os doze aldeamentos surgido à beira-mar.

Já Carapicuíba originou-se de uma extensa fazenda de índios administrados descidos do sertão ou libertados da escravidão. Tal propriedade pertencia a Afonso Sardinha que, junto com sua esposa Maria Gonçalves, doou em 9 de julho de 1615 ao Colégio de São Paulo, a referida terra juntamente com a capela Nossa Senhora das Graças, passando formalmente aos jesuítas a direção da aldeia. 


\subsection{Histórico da Aldeia de Carapicuíba}

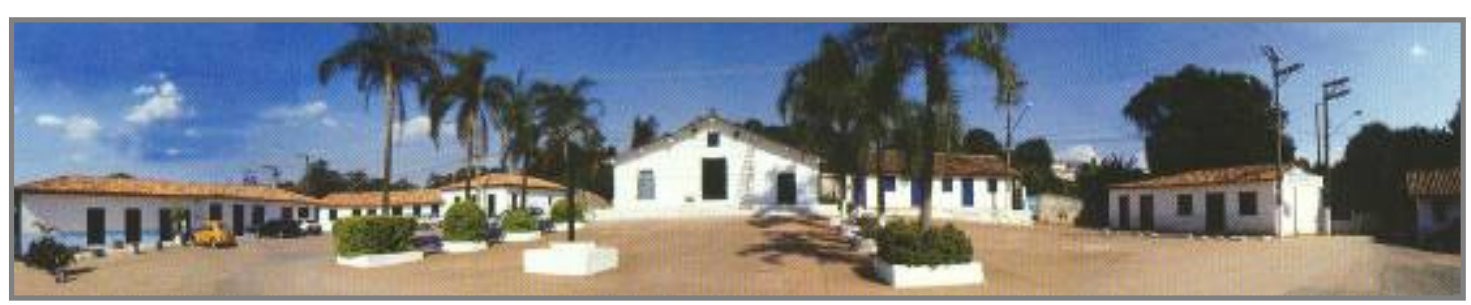

Figura 30 - Aldeia de Carapicuíba - Fonte Iphan. Foto: Victor Hugo

\subsubsection{Localização}

Situada em um terraço do Planalto Paulistano, e protegida por um amplo anfiteatro de morros e colinas - na porção oeste da Região Metropolitana de São Paulo - a Aldeia de Carapicuíba, se mostra intacta na sua implantação quadrangular do século XVI.

Fundada por sesmaria ${ }^{32}$ em 1580, pertence ao município de Carapicuíba e dista apenas 24 quilômetros e meio do centro de São Paulo. Tem como municípios limítrofes: Barueri,

\footnotetext{
32 Sesmaria é um instituto jurídico português (presente na legislação desde 1375) que normatiza a distribuição de terras destinadas à produção. Este sistema surge em Portugal durante 0 século XIV, quando uma crise agrícola atinge o país. 0 Estado, recém-formado e sem capacidades de organizar a produção de alimentos, decide legar a particulares essa função.
} 
Osasco, Cotia e Jandira; com acesso pela Rodovia Raposo Tavares (SP-270) pela Estrada da Aldeia e Rodovia Castelo Branco (SP-280) por meio do trecho oeste do Rodoanel Mário

Covas.

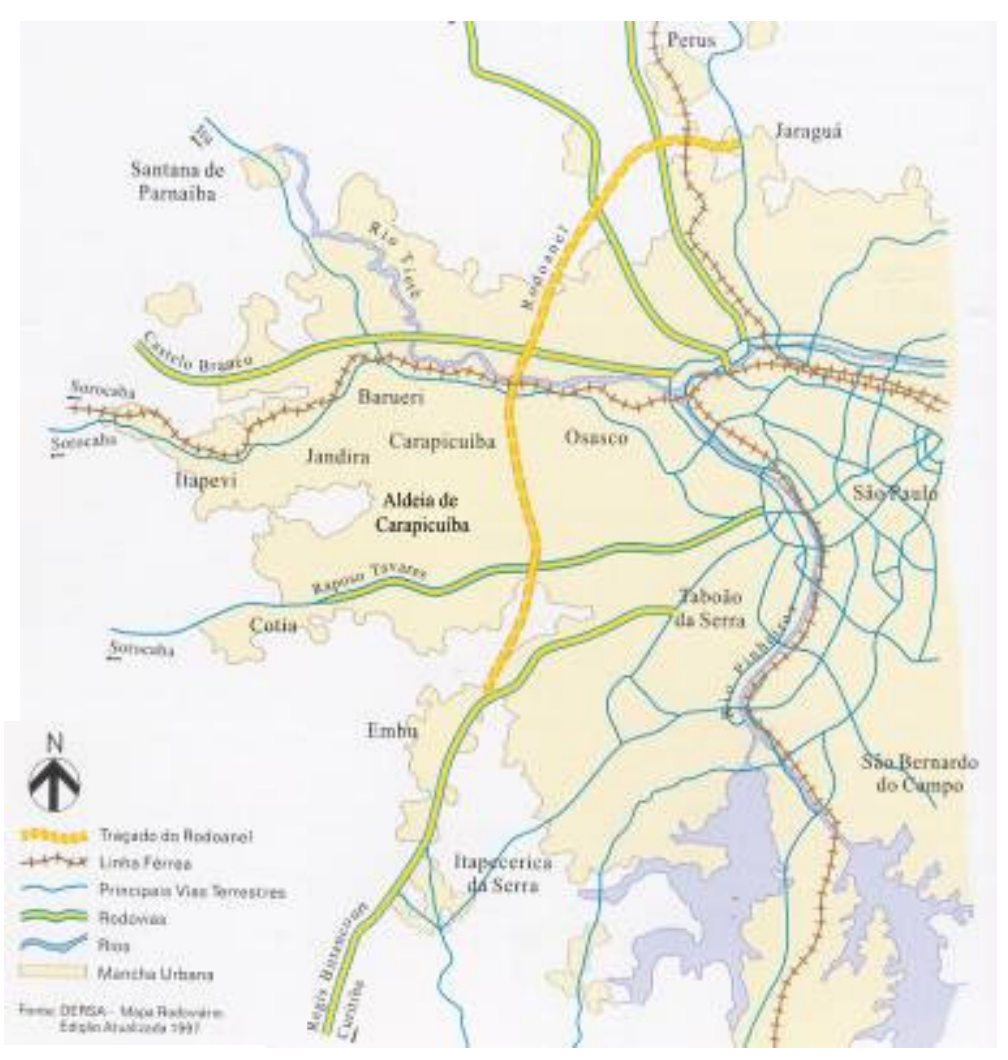

Figura 31 - Localização da Aldeia de Carapicuíba - Fonte Dersa.

Quando a conquista do território brasileiro se efetiva a partir de 1530, o Estado português decide utilizar o sistema sesmarial no além-mar, com algumas adaptações. A partir do momento em que chegam ao Brasil os capitães-donatários, titulares das capitanias hereditárias, a distribuição de terras a sesmeiros passa a ser uma prioridade, pois é a sesmaria que vai garantir a instalação da plantation açucareira na colônia. 


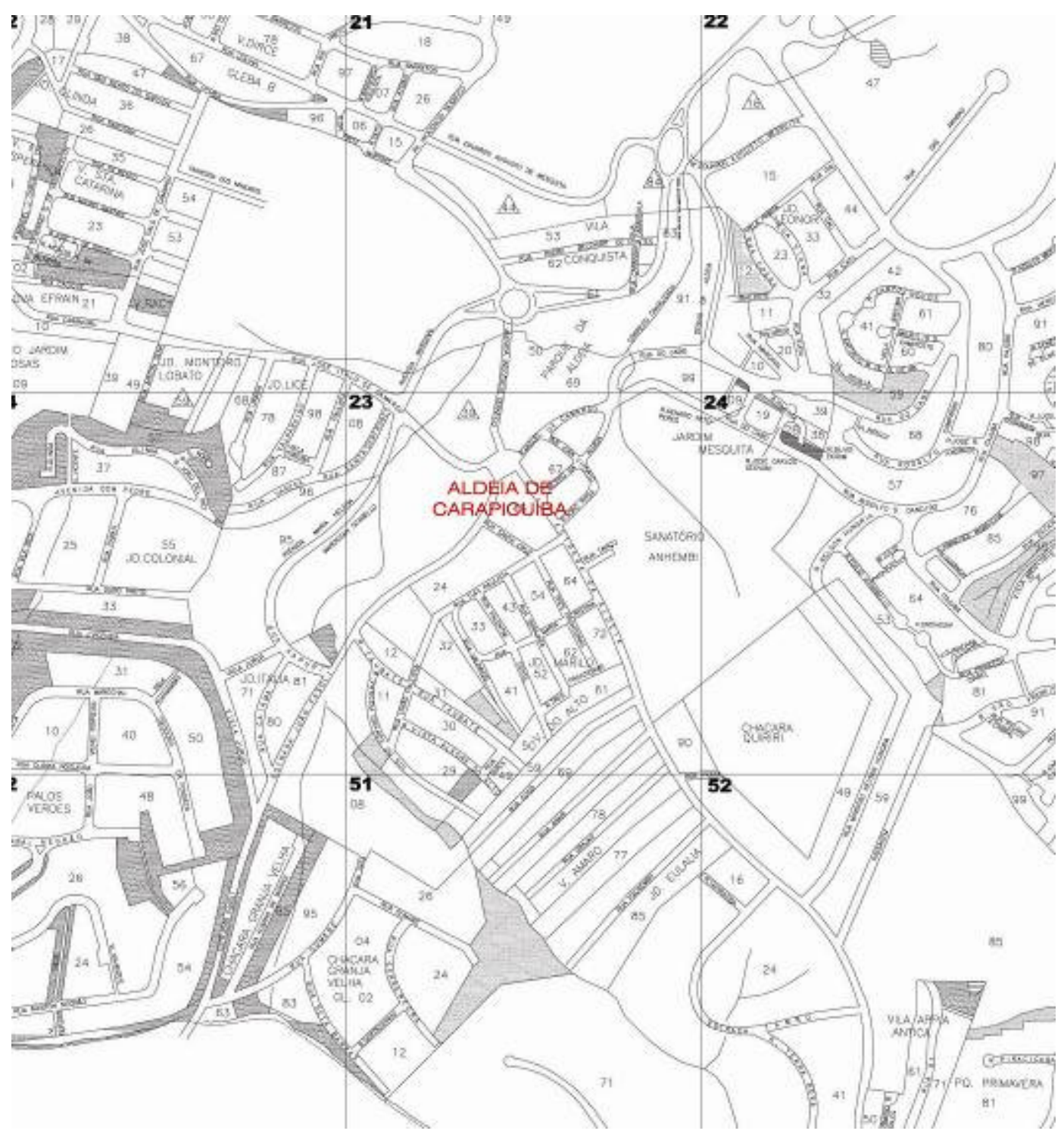

Figura 32 - Mapa Carapicuíba - Detalhe da região da Aldeia de Carapicuíba - Fonte P. M. de Carapicuíba. 


\subsubsection{Caracterização}

Diferente das outras aldeias, Carapicuíba foi implantada com significativa distância dos grandes cursos d'água. A 755 metros de altitude, seu território ocupa área acidentada, a alguns quilômetros do rio Tietê, ao longo do vale do córrego da Aldeia, afluente da margem esquerda do ribeirão Carapicuíba que deságua no Tietê, a oeste de Osasco.

[...] 0 núcleo localizou-se numa espécie de cunha na margem direita do citado córrego, entre o Fazenda Velha de um lado e outro pequeno curso d'água de outro. Essa cunha forma quase que um promontório, não muito pronunciado, dentro de um grande alvéolo acentuado pela convergência, nessa área, de vários pequenos cursos. Daí se segue que, se de um lado o aldeamento se encontra em posição elevada em relação ao curso do córrego da Aldeia, próximo da água, porém protegido das enchentes, de outro lado está como que aninhado no fundo do alvéolo, protegido pelas elevações (mais de $840 \mathrm{~m}$ ) que 0 circundam. Diferentemente de todos os aldeamentos... Carapicuíba ficou um pouco à margem dos principais eixos de circulação, fato que poderia contribuir para explicar sua maior permanência. (PETRONE, 1995, p.150) 


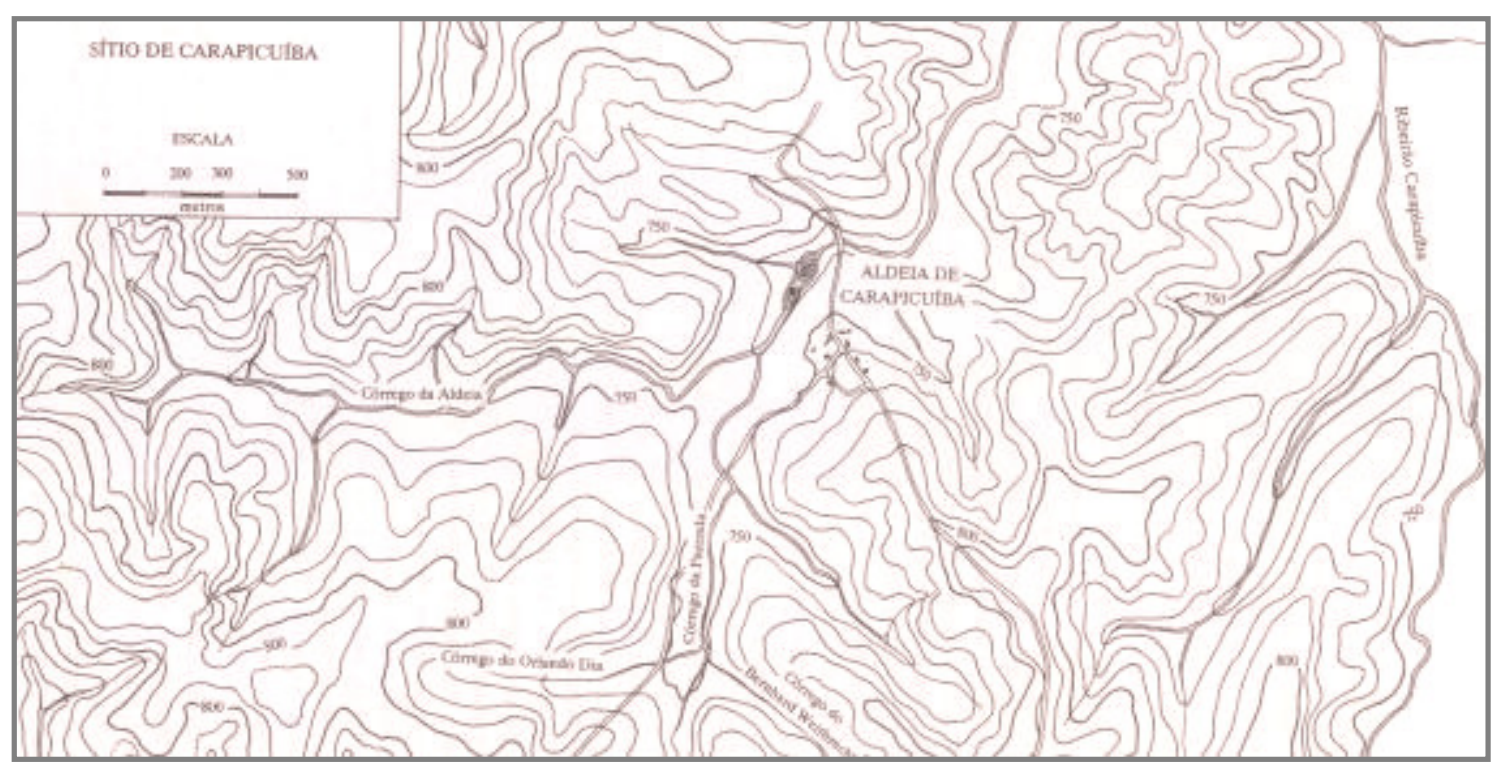

Figura 33 - Sítio de Carapicuíba. Ilustração de Pasquale Petrone.

Por volta de 1689, o sítio de Carapicuíba sofreu uma tentativa de mudança para Itapecerica motivada pelos jesuítas, mas segundo Leonardo Arroyo,

"[...] que se fundamenta no Padre Manuel da Fonseca, a mudança parece que na realidade não se teria verificado; "0 que houve realmente foi a transferência dos índios da Carapicuíba para Itapecerica, com o que não concordou o Padre Belchior de Pontes, então dirigindo na aldeia [...]". 
A transferência não foi aceita pelos indígenas, então, as casas foram derrubadas e a Igreja destruída para pressioná-Ios a saída. Entretanto, os índios não abandonaram suas lavouras, fato que consolidou ainda mais a Aldeia, reconstruída gradualmente seguindo 0 traçado original a partir de 1735. Um ano depois a Igreja foi reerguida, em louvor a São João Batista. Porém, no século seguinte, a capela passa a ser em louvor a Santa Catarina, hoje padroeira da Aldeia.

Segundo SAIA, 1937

[...] Carapicuíba foi fundada precisamente numa época em que se firmavam na Capitania de São Vicente os traços da cultura jesuítica, tão marcadamente diversos daqueles com os quais os colonos haviam inaugurado o trabalho de colonização e povoamento. Traços que traduzidos em termos de arquitetura, iriam representar 0 advento de um critério preestabelecido e racional na escolha dos assentos de núcleos, em contraposição ao processo tradicional, imediatista e quase sempre precário dos colonos. Sobretudo iriam instituir nas povoações o plano quadrangular, enquanto os núcleos especificamente colonos apresentavam um aspecto desordenado e infixo. A Aldeia de Carapicuíba vai refletir essa nova orientação de trabalho colonizador [...].

Segundo consta, com a extinção da Companhia de Jesus, as terras de Carapicuíba passaram a ser de propriedade da família Camargo, ano de 1779. 
Em 1821, a assistência espiritual passou à Aldeia de Embu e somente em 1940 ficou sob responsabilidade de Cotia. Trinta e três anos depois, a região era de propriedade do Barão de Iguape, Antonio da Silva Prado, com suas atividades agrícolas e manutenção de seus costumes, mostrando-se cada vez mais um bairro rural.

No início do século XX, ano de 1903, as terras foram adquiridas por Delfino Cerqueira. Em 1922, foi feita a reurbanização da área, loteando parte da gleba. Mais tarde, faz novo Ioteamento no restante, que deu origem a uma nova vila - Vila Sylviania.

Aos poucos os imigrantes estrangeiros - principalmente italianos e japoneses - foram chegando e, em seguida, os migrantes de outros estados - Nordeste e Minas Gerais assinalando os paulistas em uma minoria. A região passa a ser predominantemente ocupada por sítios de hortifrutigranjeiros, e, nos anos 50, passou a ser absorvida pela desordenada urbanização da cidade de São Paulo que estava no início do processo de industrialização. 
Bem diferente do que ocorre tradicionalmente na formação das cidades, o centro administrativo e comercial de Carapicuíba não coincide com a área de ocupação mais antiga, e acabou por consolidar numa região a cerca de $5 \mathrm{~km}$, situação favorecida pela construção da estação da Estrada de Ferro Sorocabana, em 1921, e posteriormente pela abertura da Rodovia Castelo Branco, já nos anos 60. Deste novo centro a ocupação se expandiu radialmente, atingindo a antiga aldeia, antes isolada na área rural.

Em 1970, 0 perímetro da Aldeia de Carapicuíba já estava inserido na região urbana do município, e a cidade crescia rapidamente sem qualquer planejamento, o que acabou caracterizando-a como cidade-dormitório. 


\title{
2.3 A Aldeia como Patrimônio e suas manifestações
}

\author{
“0 tombamento não é um processo de mumificação, \\ os monumentos têm naturalmente a capacidade de \\ satisfazer a programas quais forem, conforme seus espaços \\ disponíveis, quais forem as circunstâncias ou \\ quais forem as conveniências". \\ Carlos Alberto Cerqueira Lemos
}

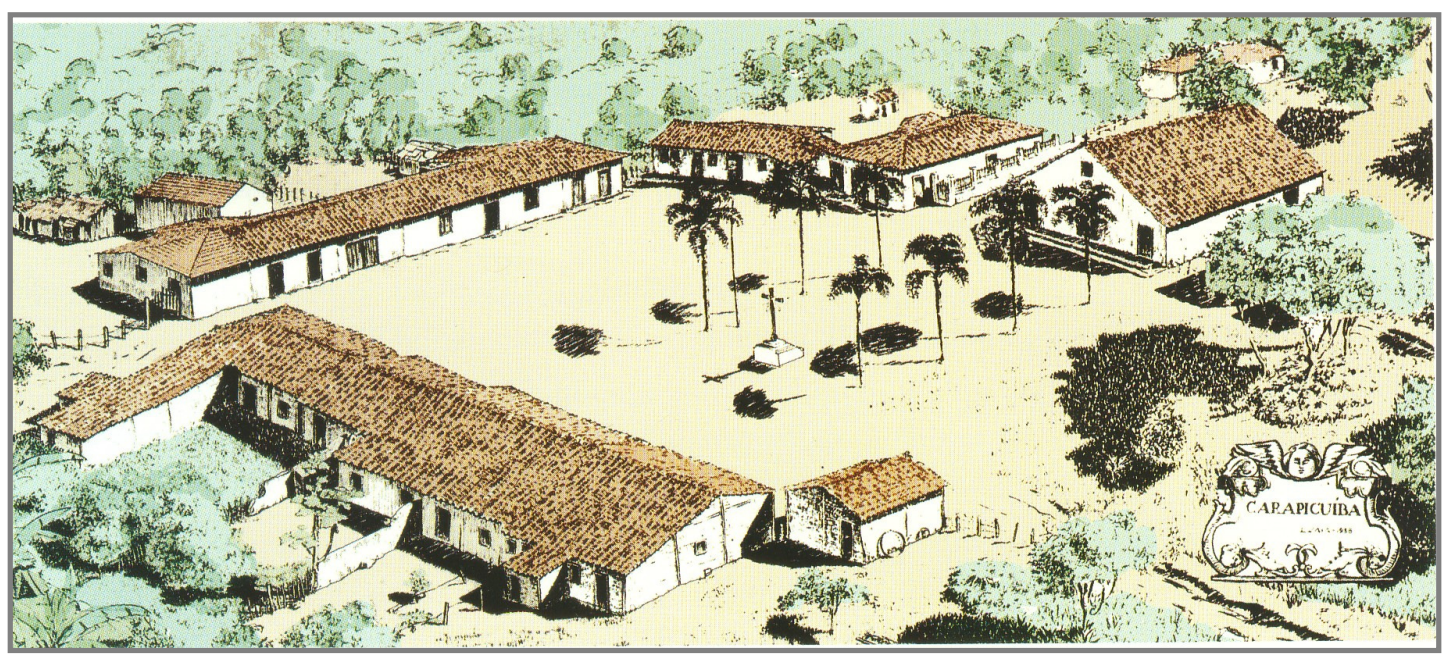

Figura 34 - Croqui da Aldeia - desenho de Luis Saia. Fonte: IPHAN. 


\subsubsection{Patrimônio}

Após a conclusão do estudo de Luis Saia sobre a Aldeia de Carapicuíba, desenvolvido no fim dos anos 30, a antiga SPHAN - Subsecretaria do Patrimônio Histórico e Artístico Nacional atualmente IPHAN, deu início ao processo de tombamento do conjunto arquitetônico e urbanístico efetivado em 1940 (processo 0218-T-39). No ano seguinte, a Capela de São João Batista, hoje Capela de Santa Catarina, também foi tombada (processo 0221-T-39). Já o tombamento estadual, pelo CONDEPHAAT, ocorreu em 1973.

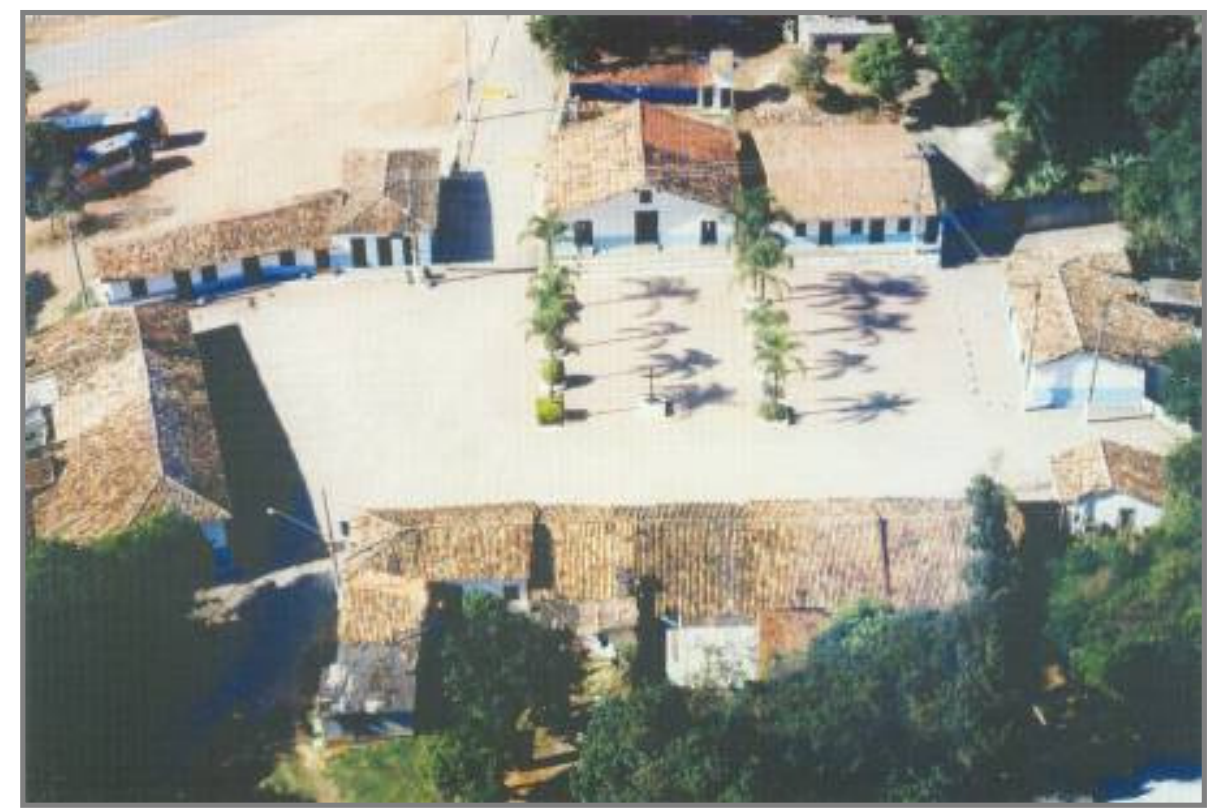

Figura 35 - Foto aérea da Aldeia. Fonte: Prefeitura Municipal de Carapicuíba, 2002. 
É importante ressaltar que a aldeia missionária de Carapicuíba é um dos poucos bens tombados existentes que remete ao povo ou a arquitetura popular, sendo que a maioria que restou representa a Igreja ou a classe dominante.

A área em questão é de aproximadamente $8.000 \mathrm{~m}^{2}$ e constituiu-se posteriormente em Zona de Preservação Histórica - ZPH.

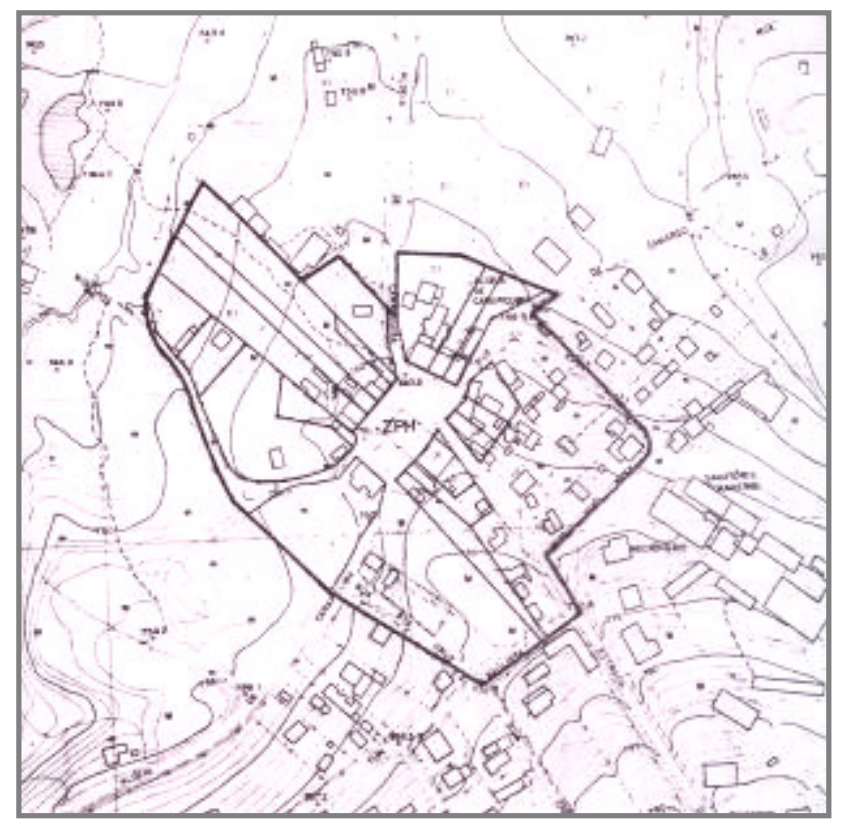

Figura 36 - Perímetro da Área de Preservação Histórica. Fonte: EMPLASA, 1973. 
Segue descrição que consta no documento de tombamento sobre o Conjunto Arquitetônico e Urbanístico da Aldeia de Carapicuíba.

[...] Descrição: Aldeamento jesuíta instalado numa sesmaria de 1580. A importância deste conjunto está na permanência de sua primitiva feição urbanístico-arquitetônica. Todavia, é também representativo da precariedade dessas instalações em território paulista, quando comparado às grandes missões do Sul. As unidades de residência, no entanto, receberam mudanças em seu sistema construtivo. Tombado em 1940, o conjunto recebeu intervenções para a sua consolidação em 1954, 1956 e em 1960/61[...].

Processo 0218-T-39 IPHAN

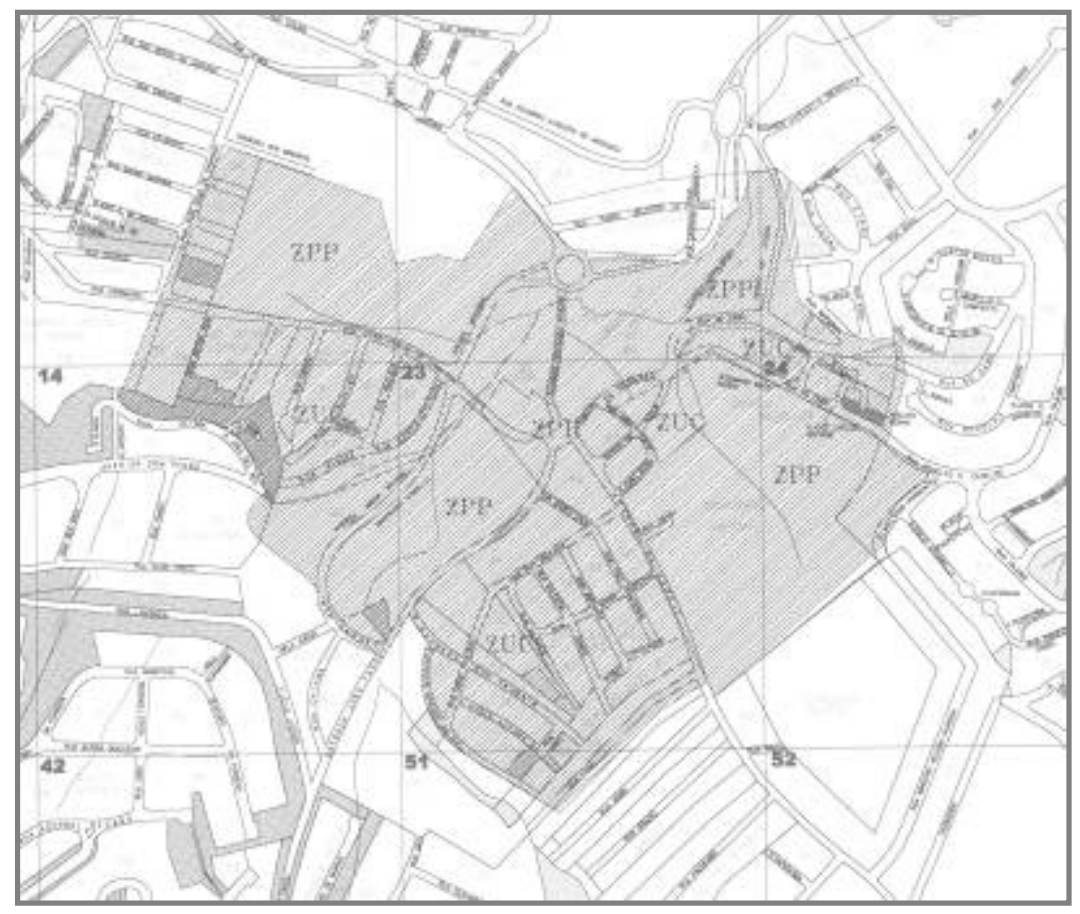

Figura 37 - Perímetro das Zonas de Preservação. Fonte P.M. de Carapicuíba. 
Apesar de o próprio Saia considerar que seu estudo, de 1937, sobre a Aldeia de Carapicuíba, continha informações equivocadas 0 trabalho conseguiu levantar problemas e informações fundamentais sobre a aldeia.

A partir da descrição que faz do terreiro e da ilustração, vemos que: as casas do lado esquerdo da capela (hoje a Secretaria Municipal de Cultura - casas XVII e XVIII) e a casa que atualmente fecha a lateral esquerda do terreiro (Associação São Joaquim - casa XIX) são construções recentes.

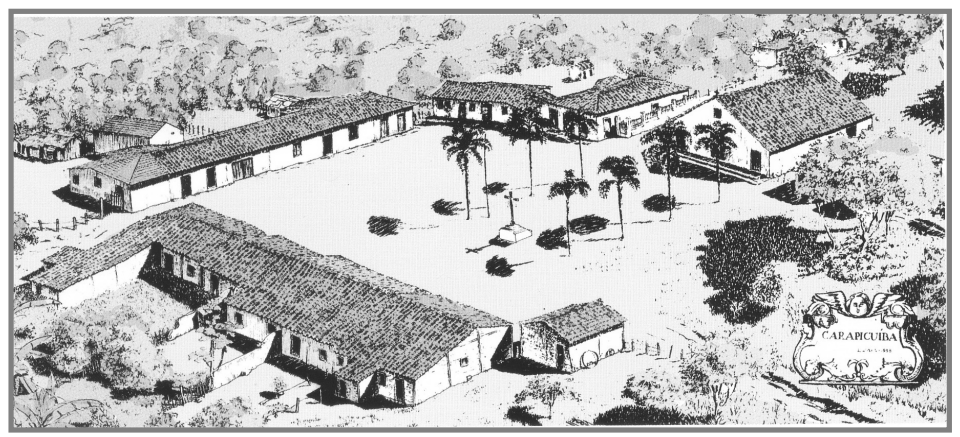

Fiqura 38 - Ilustracão de Luis Saia. Fonte IPHAN.

0 caminho desce numa rampa de uns 200 metros de comprimento para entrar quase no meio do pátio, tendo à esquerda a Capela de Santa Catarina. Em frente e à direita se desenvolvem os dois lados do retângulo inteiramente preenchido com edifícios de habitação. No lado que fica à esquerda da capela só uma residência fecha 0 canto do fundo, o resto se abrindo numa larga visada pelos campos e colinas dos arredores. É possível que esta parte aldeada estivesse primitivamente tomada também por construções. Não encontrei, entretanto vestígios disso nem em ruínas, nem na tradição local [...].

(SAIA, 1937, p.17) 


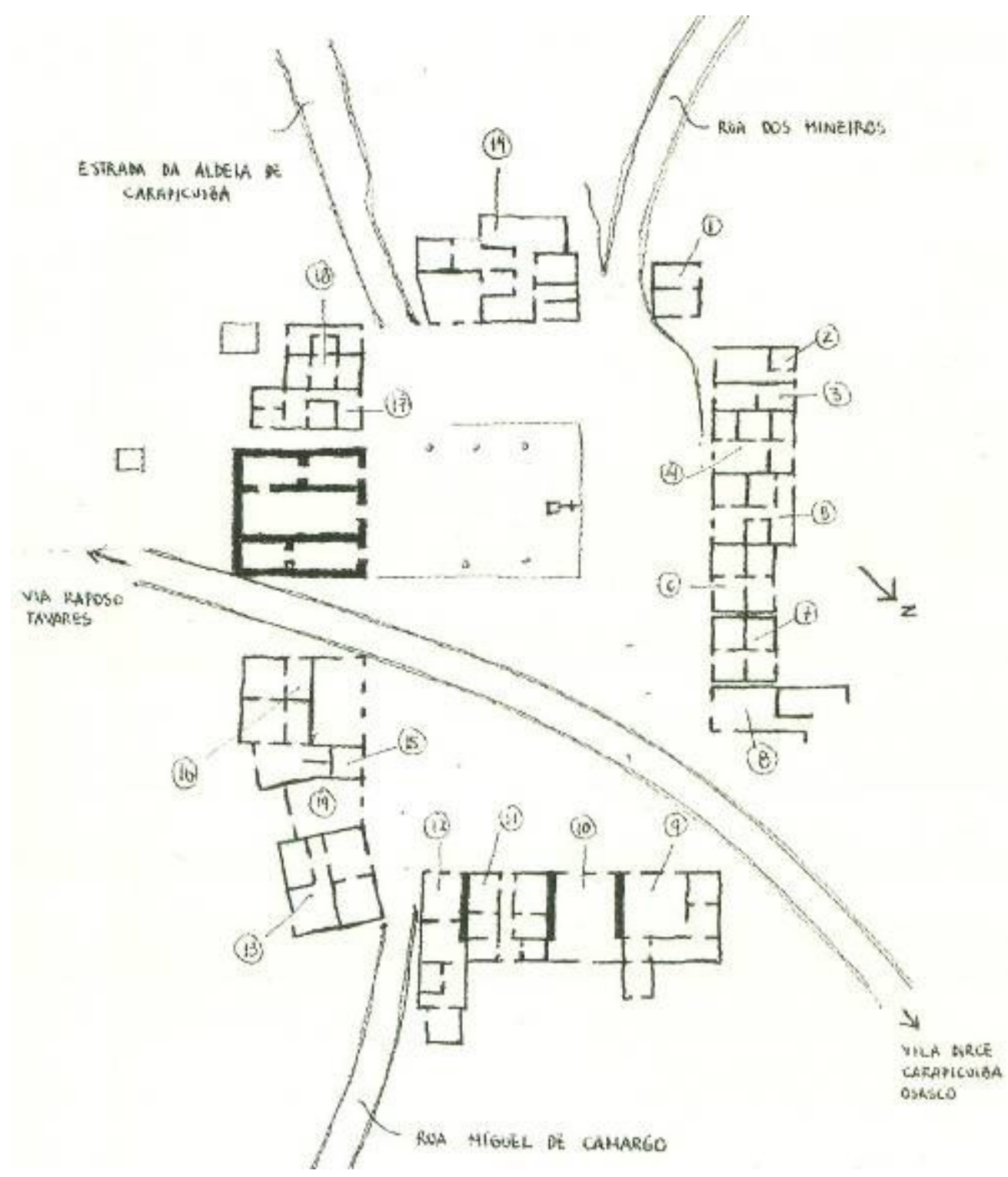

Figura 39 - Planta da Aldeia de Carapicuíba - desenho de Luis Saia. Fonte: IPHAN. 
Além disso, Saia verificou que as casas VI, VII e VIII estavam separadas 30 e 40 centímetros entre si, sugerindo construção recente que, apesar de seguir a sistemática antiga de construção, não foram erguidas geminadas entre si.
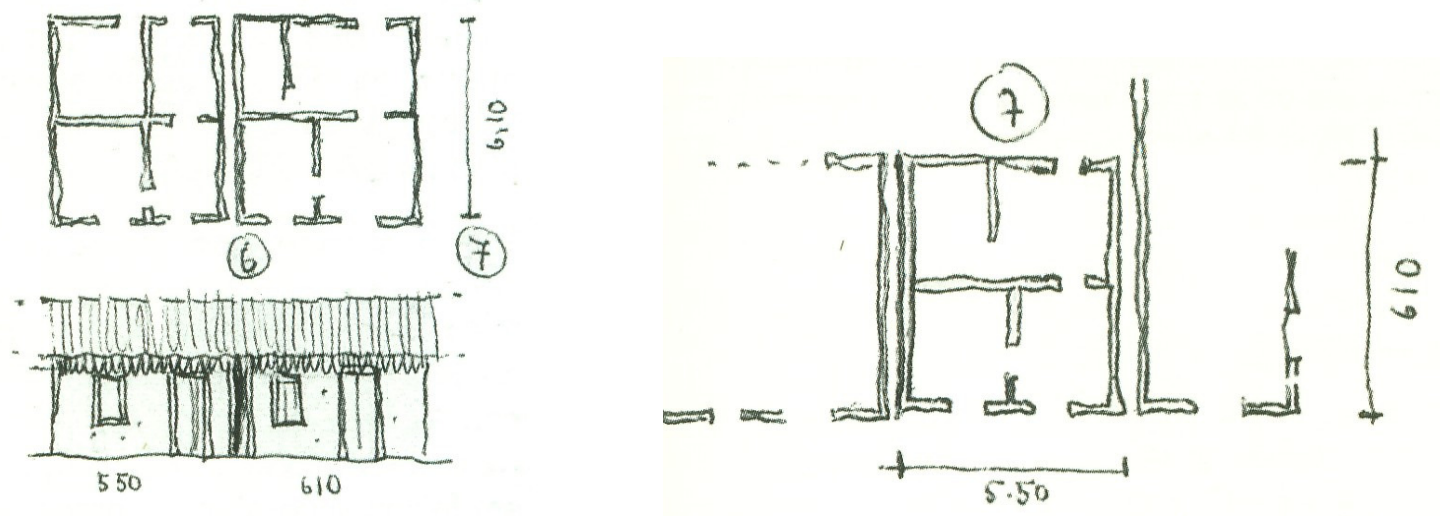

Figura 40 e 41 - desenhos das casas VI e VII - Luis Saia. Fonte IPHAN. 
Outra informação importante que Saia levantou nas casas X, XI e XII foi a presença de três paredes originais de taipa, resquícios da construção do século XVI. ${ }^{33}$

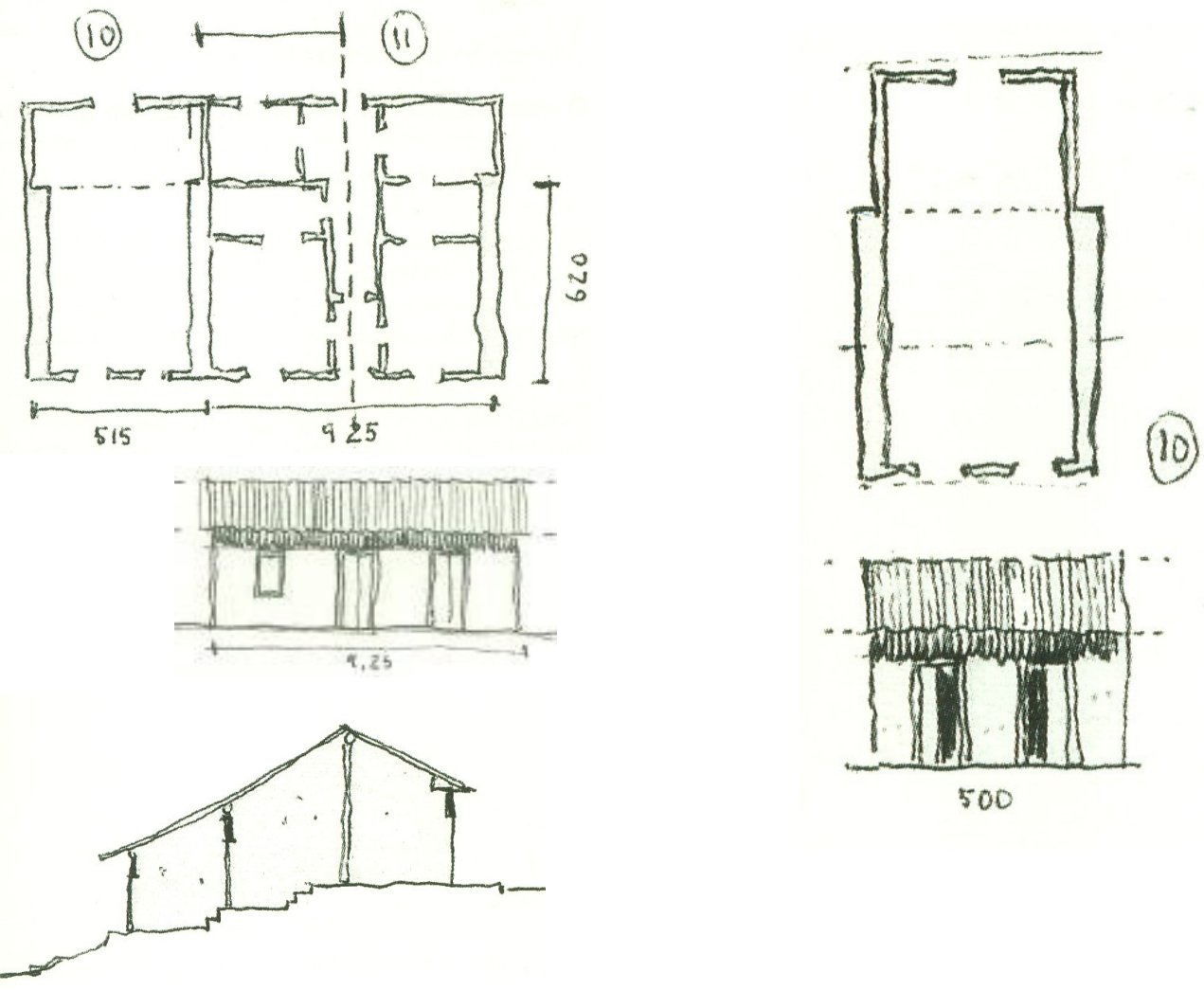

Figura 42 e 43 - desenhos das casas X e XI - Luis Saia. Fonte IPHAN.

${ }^{33}$ Verificar estudo de Antonio Luiz Dias de Andrade, o Janjão, sobre as habitações da Aldeia de Carapicuíba e suas estruturas. MORI, Victor Hugo; SOUZA, Marise Campos; BASTOS, Rossano Lopes; GALLO, Haroldo. Patrimônio: Atualizando o debate. São Paulo, IPHAN, 2006. 
As primeiras intervenções de restauro ocorreram em meados dos anos 50 , que incluía a capela e posteriormente as casas. As obras realizadas não foram apenas paliativas, um exemplo dos esforços do IPHAN é a casa que hoje abriga o Correio, inteiramente remontada em 1956.
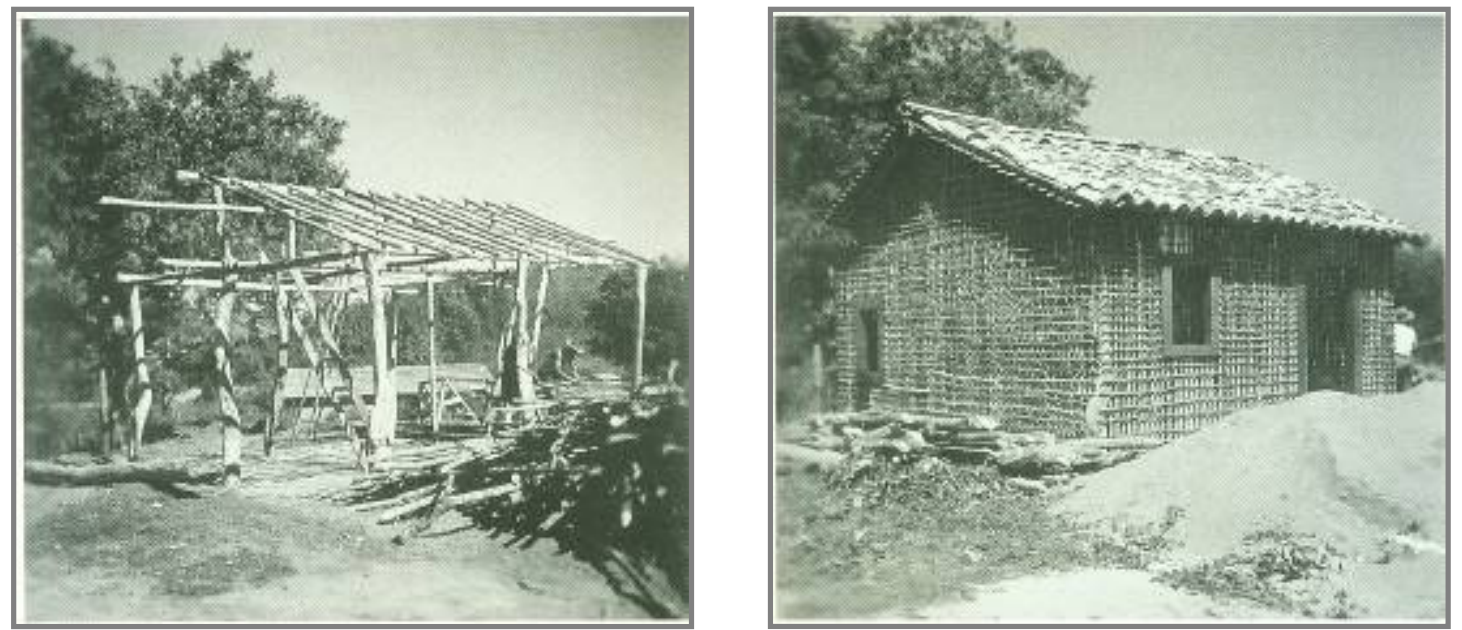

Figura 44 e 45 - Imagens da remontagem da casa que abriga hoje o Correio, feita em 1956. Fonte Iphan. Foto: Germano Graeser. 


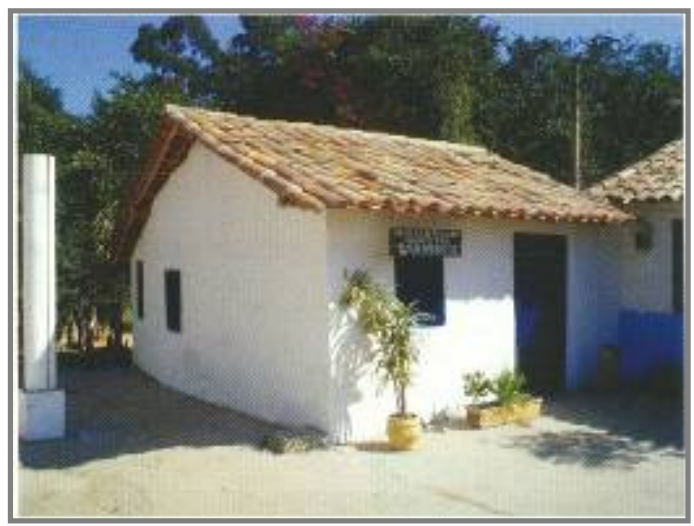

Figura 46 - A casa restaurada em 2004. Fonte Iphan Foto: Antonio L. Sarasá.

Entretanto, isso não quer dizer que todas as obras ocorridas no quadrilátero - após seu tombamento - respeitaram as regras estabelecidas pelo IPHAN. Ao contrário, a própria Prefeitura de Carapicuíba, em suas diversas gestões, executou várias intervenções equivocadas, como 0 asfaltamento da Estrada da Aldeia que atravessava 0 pátio, e a reforma do chão de terra que incluía a construção de muretas e escadas para compensar o desnível do terreno. 


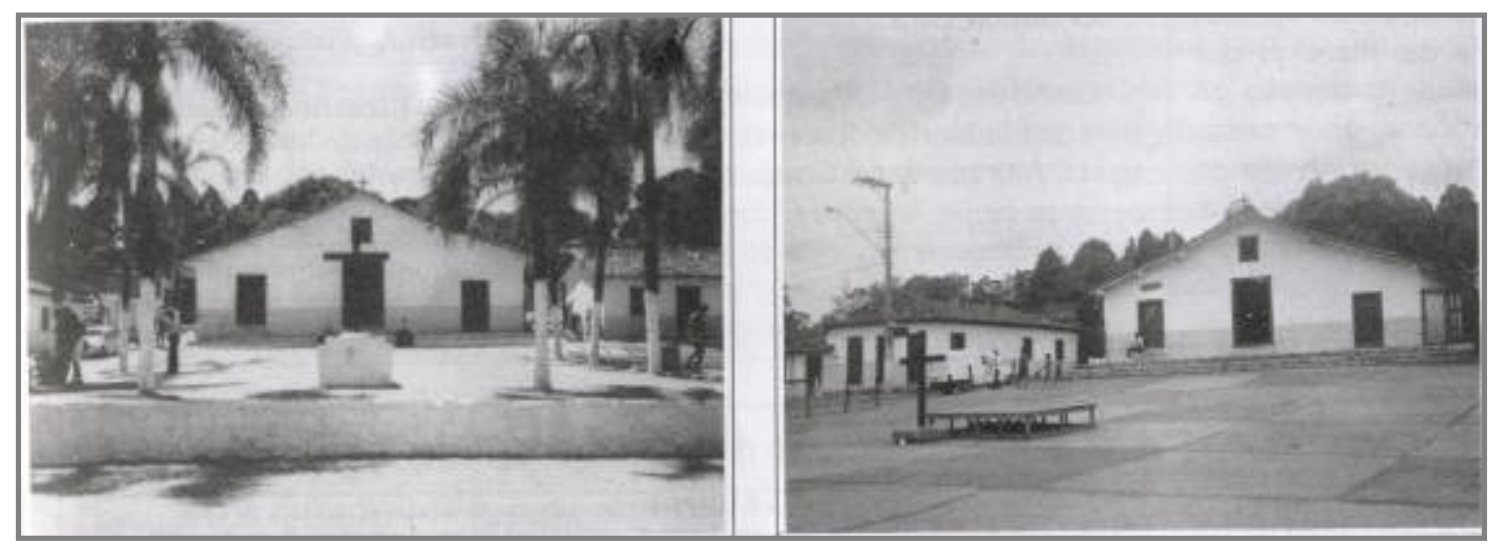

Figura 47 - 0 pátio da Aldeia em 1995 e 1996. Fonte: Jornal Daqui, 1997.

Nota-se que na imagem sem as muretas as palmeiras também foram retiradas. Segundo especialistas, esta configuração de "adro franciscano" com palmeiras e cruzeiro descaracteriza formalmente o conjunto, gerando muita controvérsia e desagrado da comunidade a ponto de as palmeiras serem replantadas.

Outro fato polêmico foi a promoção de eventos pela prefeitura que culminaram na construção de duas ocas por índios do Xingu nos arredores do pátio. Tal acontecimento novamente induz a informação enganosa da história e formação da Aldeia. 


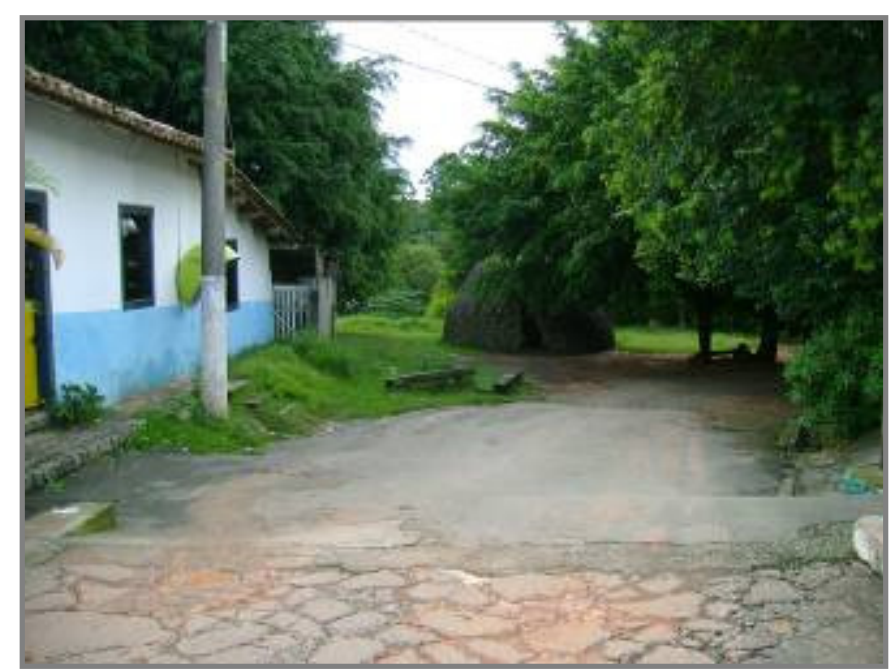

Figura 48 - Uma das ocas encomendada pela Prefeitura aos índios do Xingu. Fonte: Arquivo pessoal, 2008.

Apesar de já existir um projeto de desvio desde 0 ano de 1977, que previa 0 redirecionamento do tráfego a cerca de 200 metros da área do pátio da Aldeia em vias de contorno, a Prefeitura Municipal de Carapicuíba solicitou à Companhia de Metropolitano de São Paulo - METRÔ, em 1985, o desenvolvimento de Projetos Funcionais do Desvio Viário e de Urbanização da área da Aldeia, tendo em vista a recuperação e preservação do sítio histórico. 
Nessa mesma época, sob responsabilidade da EMPLASA e a pedido também da prefeitura, foram criadas as diretrizes de uso e ocupação do solo da Aldeia e área circunvizinha que gerou a Lei de Preservação da Aldeia de Carapicuíba. Posteriormente, em 2004, a prefeitura municipal cria o Parque Cultural da Aldeia de Carapicuíba, medida que efetivamente protege 0 quadrilátero histórico. ${ }^{34}$

\footnotetext{
${ }^{34}$ Mais adiante, 0 capítulo 3 "A Aldeia de Carapicuíba Contemporânea" discorre sobre a criação do Parque Cultural da Aldeia de Carapicuíba.
} 


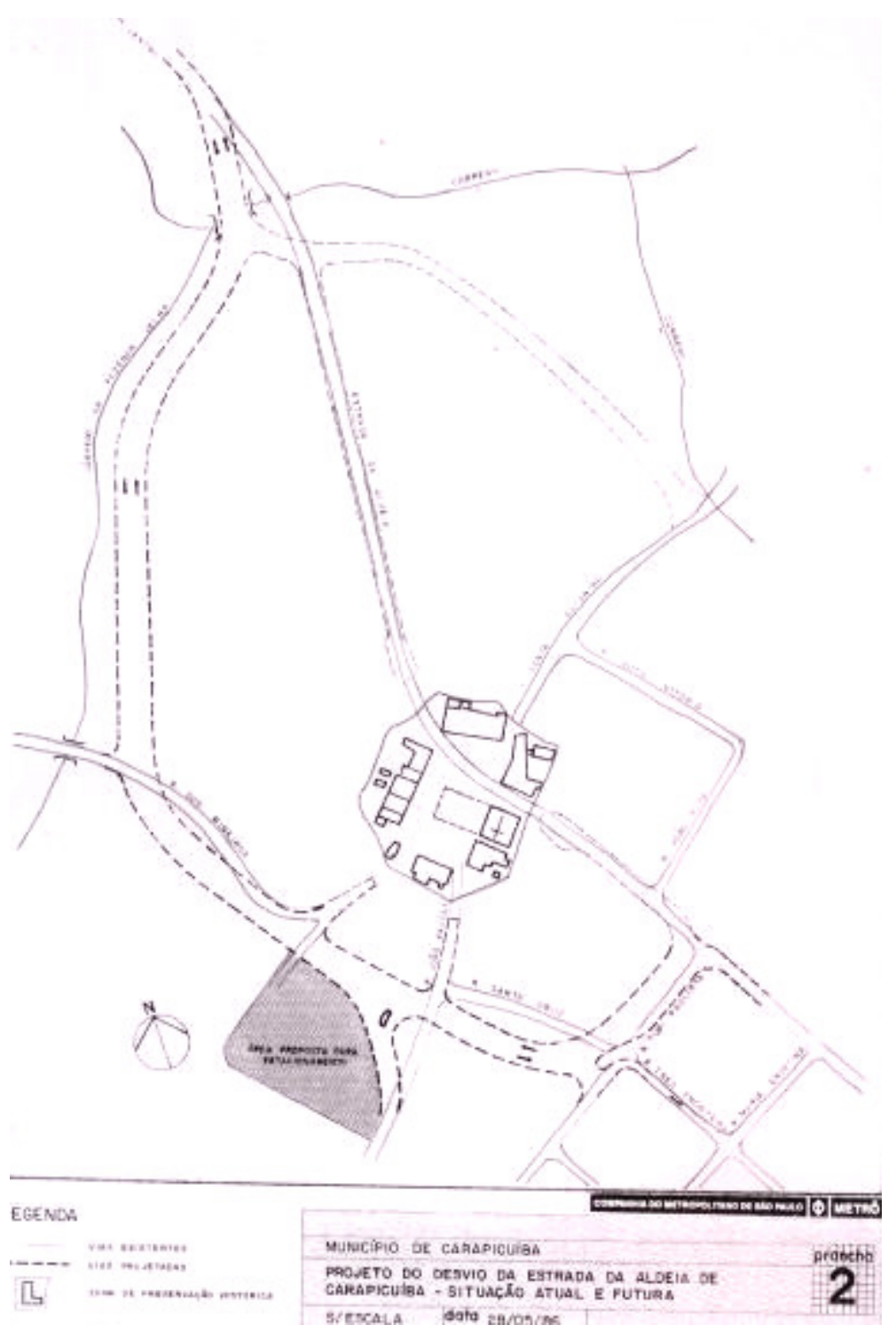

Figura 49 - Projeto de Desvio da Estrada da Aldeia. Fonte: METRÔ, 1986.

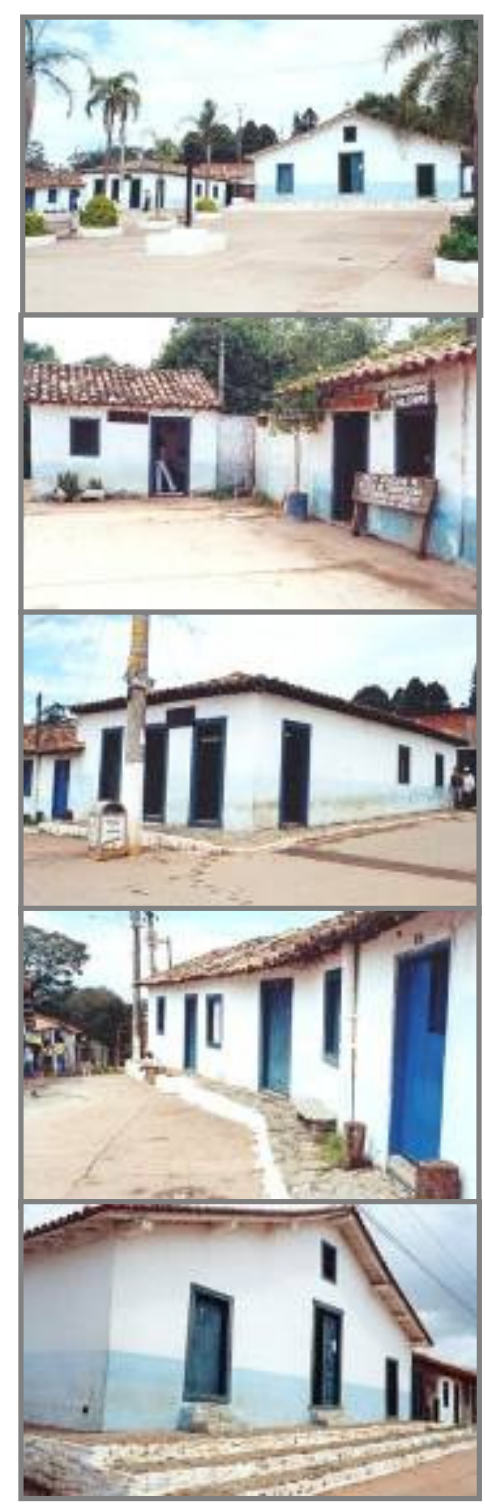

Figuras 50 a 54 - Imagens da Aldeia de Carapicuíba. Fonte: EMPLASA. Foto: J.Cruz 


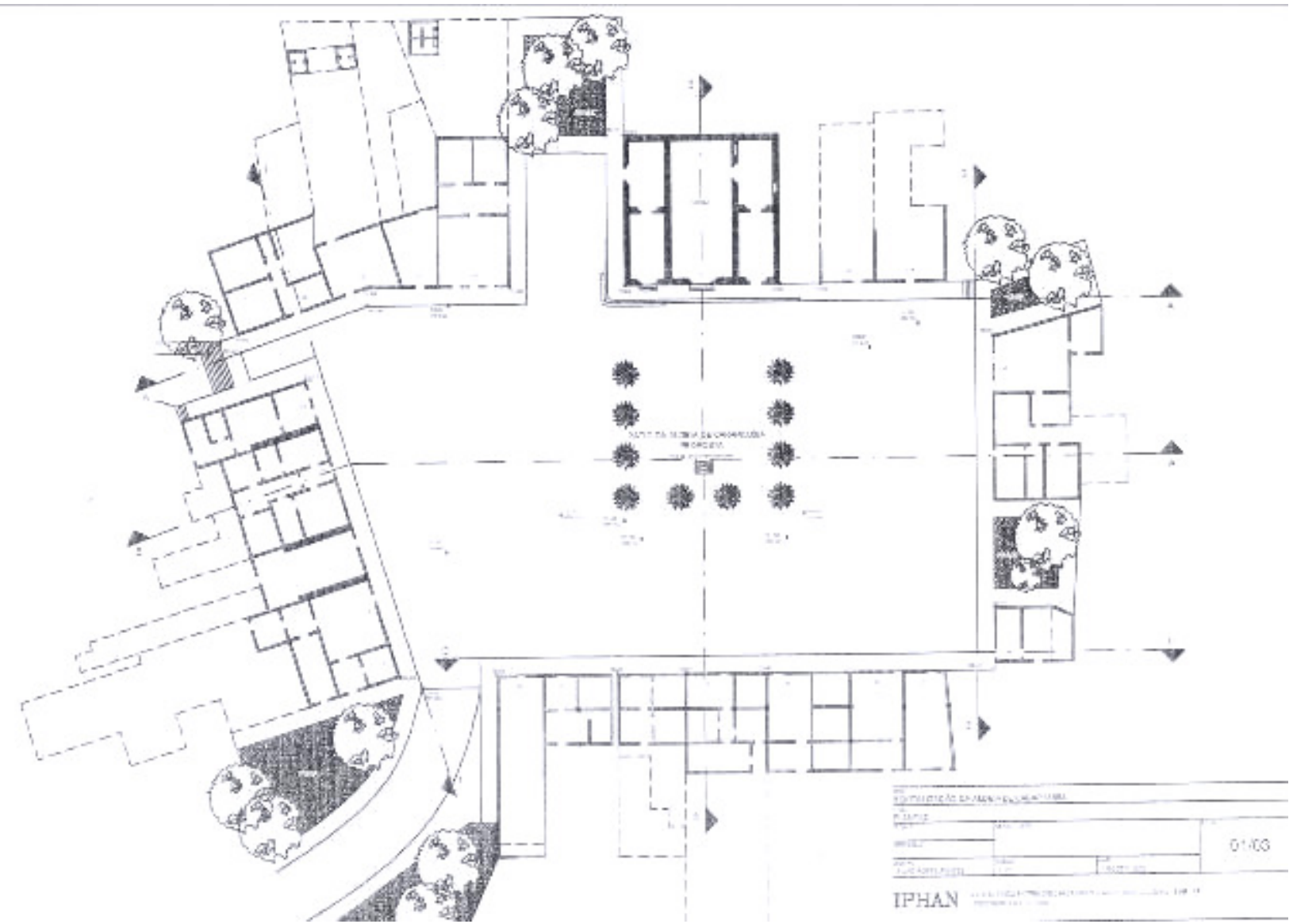

Figura 55 - Proposta do IPHAN - Revitalização da Aldeia de Carapicuíba, 2003. Fonte: IPHAN. 


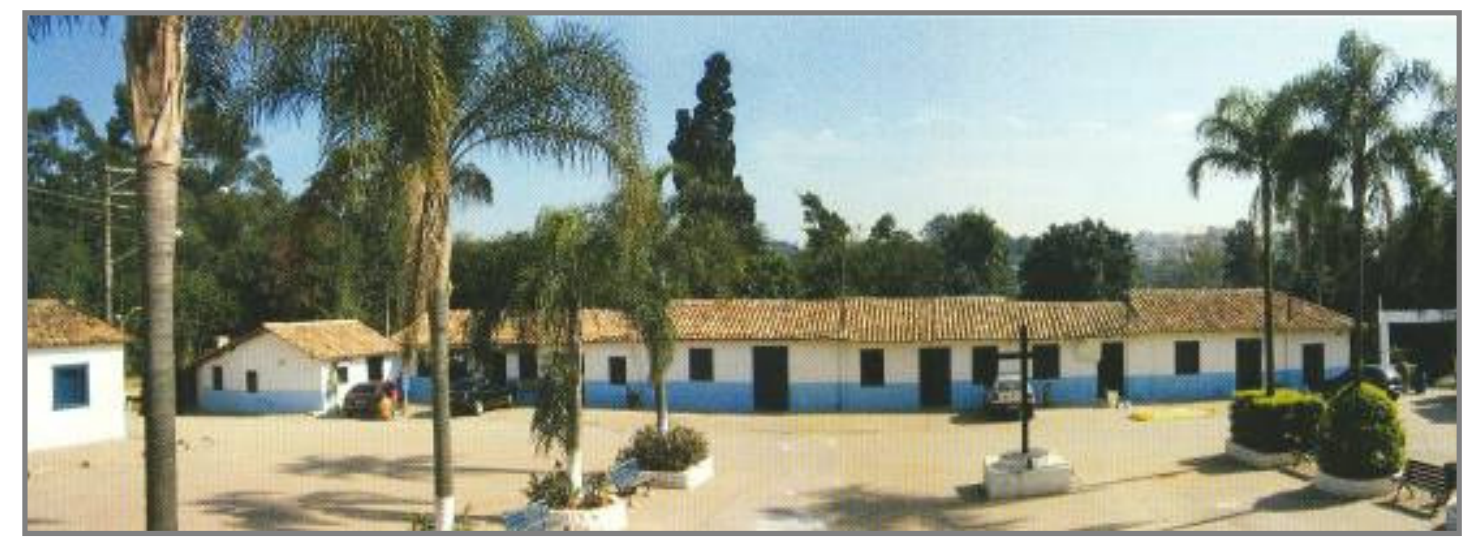

Figura 56 - Vista parcial da Aldeia de Carapicuíba. Fonte: IPHAN, foto: Victor Hugo Mori.

Mesmo com todo o esforço do IPHAN, muitas construções precárias e anexos totalmente irregulares foram construídos dentro da faixa de preservação de 300 metros. Ocorreram várias demolições de elementos agressores nas casas do quadrilátero jesuítico até chegar à configuração de hoje, considerada em boas condições, apesar de ainda não ser a ideal para um patrimônio histórico de extrema importância e valor. 


\subsubsection{Manifestações da Aldeia}

Tudo indica que a intensa ação catequizadora dos padres inacianos originou uma das mais significativas manifestações da tradição paulista: a Festa de Santa Cruz ${ }^{35}$. Fruto da fusão de elementos católicos - culto da cruz ${ }^{36}$ - e de tradições e costumes dos indígenas aldeados, os jesuítas conseguiam veicular com sucesso a mensagem do cristianismo apoiados em práticas pagãs.

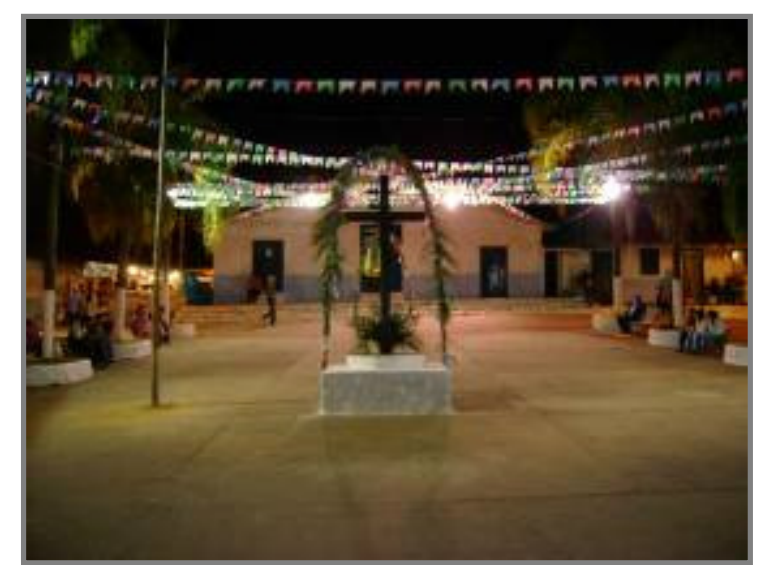

Figura 57 - 0 pátio da Aldeia de Carapicuíba preparado para a Festa de Santa Cruz. Fonte: arquivo pessoal, 2008.

\footnotetext{
${ }^{35} 0$ presente trabalho registra um panorama geral sobre a Festa de Santa Cruz. Para informações mais detalhadas, consultar livro de Eduardo A. Escalante "a Festa de Santa Cruz da Aldeia de Carapicuíba".

${ }^{36}$ Pero Correa, em 1554, informa sobre a viagem de Nóbrega cuja "peregrinação tinha esta maneira que, quando entravam em alguma aldeã dos índios, um dos meninos levava uma cruz pequena levantada, iam cantando as ladainhas, e logo se juntavam os meninos do logar com elles".
} 
Mas, a procedência real remonta ao início do cristianismo e corresponde a Invenção da Santa Cruz de Roma, realizada no dia 13 de setembro. Na Aldeia, o festejo apresenta duração de um dia e é conhecida como Santa Cruzinha.

A Festa de Santa Cruz acontece em várias localidades do estado, porém a mais conhecida é a da Aldeia de Carapicuíba que, segundo ESCALANTE, 1981, "persiste apoiada pelo gosto da tradição e devoção do homem rural". Inicia-se no solstício de inverno, nos dias 2, 3 e 4 de maio e tem como tradição fixar uma cruz enfeitada por flores e folhas em frente de cada casa da aldeia e realizar cantos sagrados em cada uma delas, acompanhados também de uma dança devocional - Dança de Santa Cruz ou Sarabaquêể - que é o momento mais esperado. É composta por três partes, com duas características opostas: na Saudação e na Despedida, ele é religiosa, sagrada; na Roda, ela é profana e é quando todos os devotos se reúnem para cantar, dançar marcar o ritmo com as mãos, tocar instrumentos, saudar as cruzes.

${ }^{37} 0$ Padre Belchior de Pontes, ao instituir o Sarabaquê, substituiu a fogueira, em torno da qual os indígenas dançavam, por uma cruz rústica de madeira, porém, ainda hoje é acesa uma fogueira. É o fogo simbólico. 


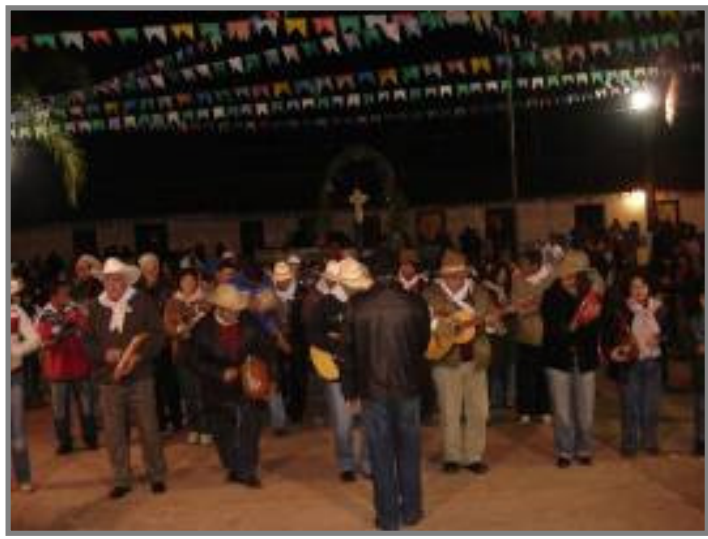

Figura 58 - Festa de Santa Cruz. Fonte: arquivo OCA, 2008.

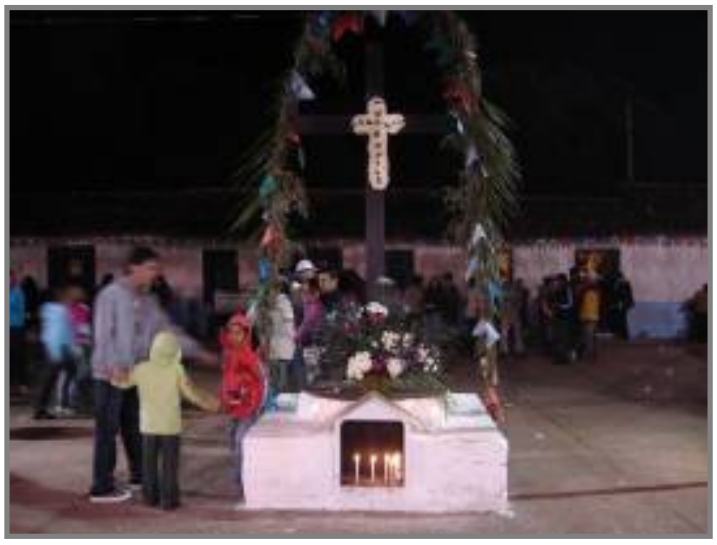

Figura 59 - 0 Cruzeiro no terreiro da Aldeia. Fonte: arquivo 0CA, 2008.

[...] As atividades de jogo, de festas, de ritos não são apenas pausas antes de retomar a vida prática ou 0 trabalho; as crenças nos deuses e nas idéias não podem ser reduzidas a ilusões ou superstições: possuem raízes que mergulham nas profundezas antropológicas; referem-se ao ser humano em sua natureza. Há relação manifesta ou subterrânea entre 0 psiquismo, a afetividade, a magia, o mito, a religião. (MORIN, 2007 P.59) 


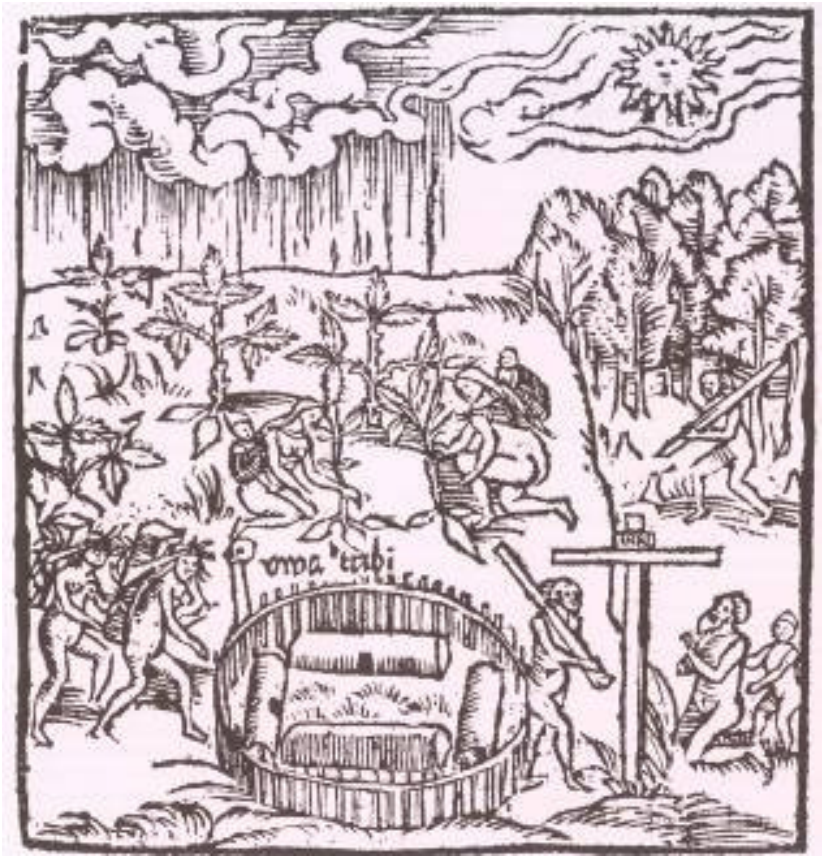

Figura 60 - A cruz em Ubatuba. Fonte: Hans Staden, sec. XVI, 1999, p. 80.

\section{Dizia Mario de Andrade:}

"[...] Se a prática de afincar as palmeiras ao longo das calçadas da rua de dez em dez metros mais ou menos é de adaptação ornamental do costume que fazia em tantas partes da Europa a árvore-de-maio ser plantada diante de cada casa, este costume permanece ainda, ritual exato, na tradição paulista da Festa da Santa Cruz. Pelo menos, tal como ela se realiza em Carapicuíba, o reduto seiscentista fundão pelo padre Belchior de Pontes. Pelas Festas de Santa Cruz, cujo dia é três de maio, cada habitante da vila segue uma tradição antiqüíssima, que consiste em afincar diante de sua casa uma cruz. Já tal como 0 descrevo me parece insofismável a substituição católica da árvore-demaio pela cruz festejada em maio. É sabido que esse foi 0 processo sistemático com que os padres da Igreja Católica usavam cristalizar as tradições pagãs, quando não podiam destruí-las de uma vez.[...]" 


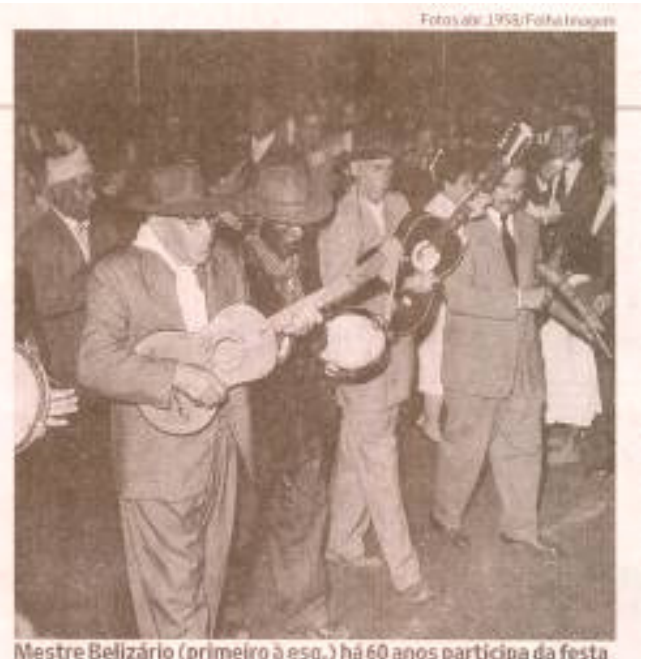

Mestre Belizário (primeiro ১esq.) hat 60 anos participa da fosta

\section{FESTA POPULAR}

CARAPICUIBA REVIVE

TRADIÇÁODOSÉCULO 18

Realizou-se ontemem Caript-

caiba(SP) a Festade Sants

Crux, comna apresentacto de

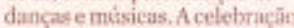

religiosa aconteceu na fazenila

SaztaCruz, antiga paragem de

bandeirantes, etesca presenca

de autoridades como e prefeito

de Sto Pualo, Adhemar de Bar-

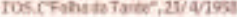

Figura 61 - Recorte jornal sobre a Festa de Santa

Cruz - Coluna "Há 50 anos". Fonte: Folha de São

Paulo, 23/04/2008

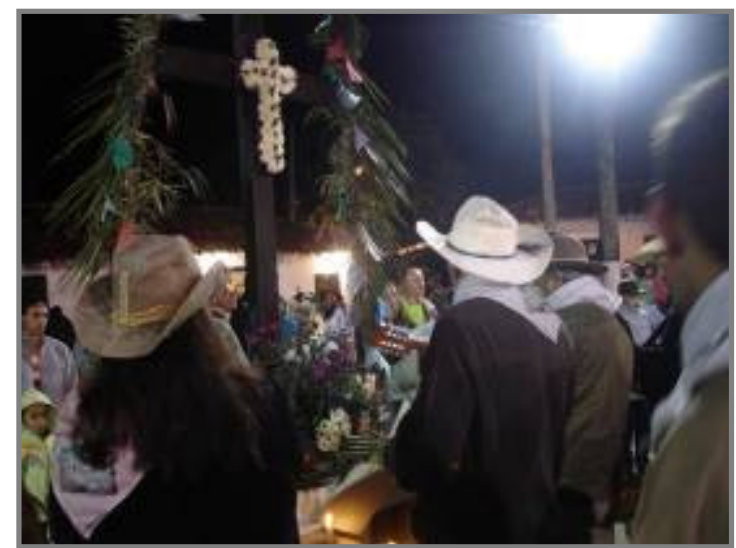

Figura 62 - exaltação da cruz na Festa. Fonte: arquivo OCA, 2008. 


\section{A ALDEIA DE CARAPICUÍBA CONTEMPORÂNEA}




\section{A ALDEIA DE CARAPICUÍBA CONTEMPORÂNEA}

Caracterização do território de Carapicuíba

Como já foi explicitado no Capítulo 2, ao longo do processo de desenvolvimento, Carapicuíba revelou-se como cidade-dormitório. Hoje, faz parte da grande área conurbada, da porção oeste, da Região Metropolitana de São Paulo - RMSP, junto com as cidades de Osasco, Barueri, Jandira e Itapevi. Ocupa área territorial ${ }^{38}$ de $34,97 \mathrm{~km}^{2}$, sendo $29 \mathrm{~km}^{2}$ urbanizada, totalizando 100 \% de taxa de urbanização.

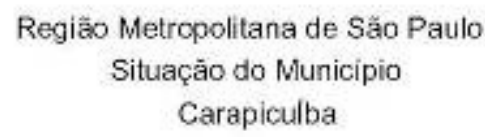

Carapiculba

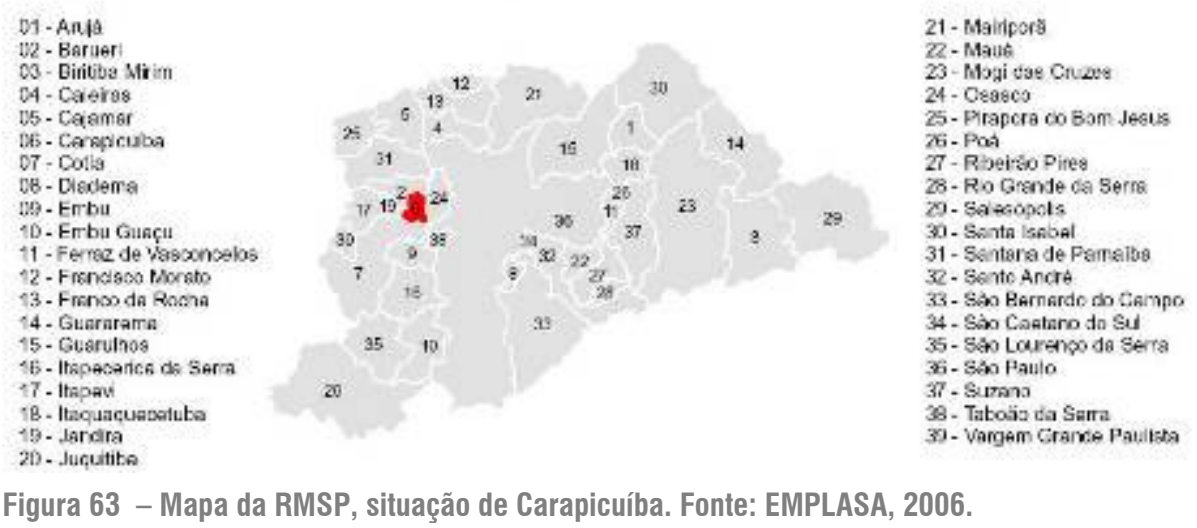

${ }^{38}$ Fonte: SEADE, 2009 - www.seade.gov.br 


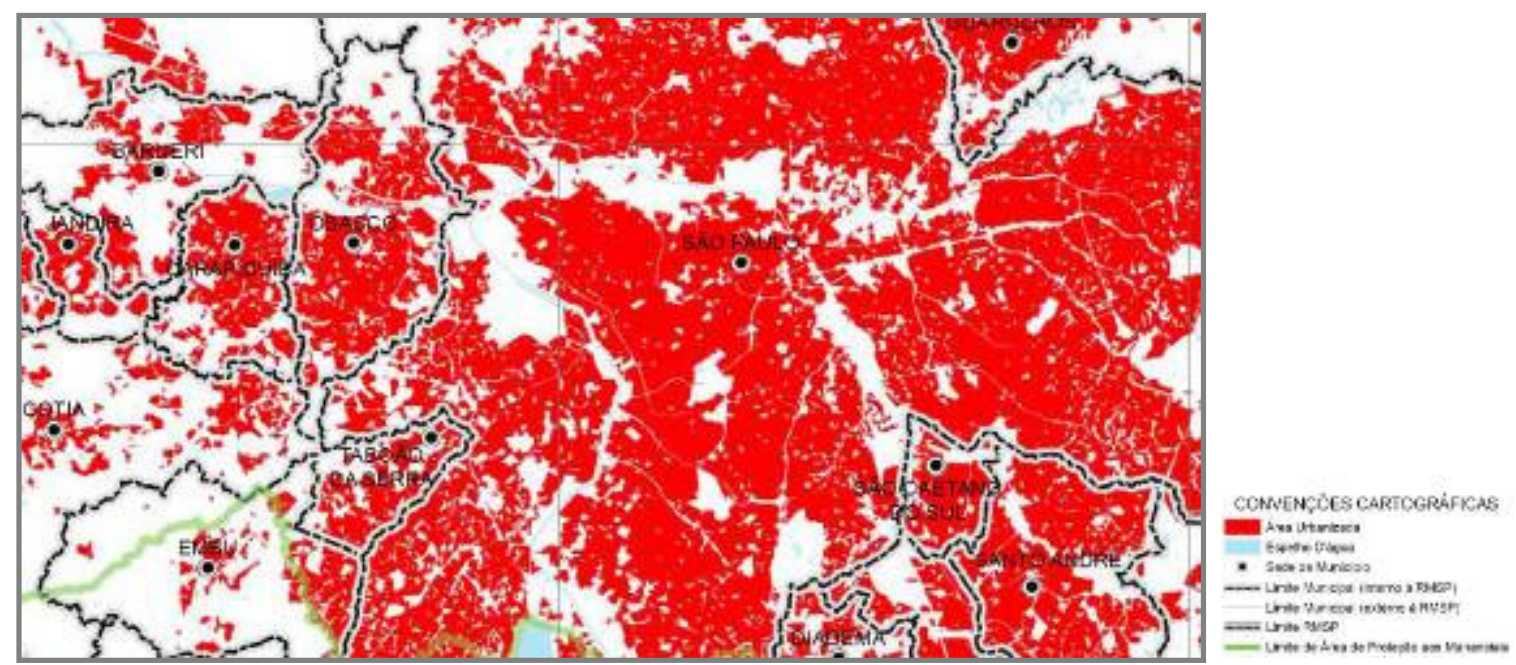

Figura 64 - Mapa da RMSP parcial, área urbanizada. Fonte: EMPLASA, 2006.

0 estudo sobre a caracterização do território do presente trabalho apóia-se nas informações e imagens contidas no Atlas de Uso e Ocupação do Solo da RMSP, e do município de Carapicuíba, produzidos em 2006, pela EMPLASA - Empresa Paulista de Planejamento Metropolitano S.A., em parceria com o FEHIDRO - Fundo Estadual de Recursos Hídricos, cujos objetivos era sistematizar "a organização, a integração, e a interação das potencialidades funcionais e produtivas da região". 
Os mapas do perfil de uso do solo retratam um conjunto real de informações que caracterizam a natureza dos usos e o estágio atual de ocupação na região. Assim, por meio dessas informações, o poder público municipal adquire uma visão mais precisa dos problemas, qualificando 0 planejamento e a definição do caráter e localização de investimentos.

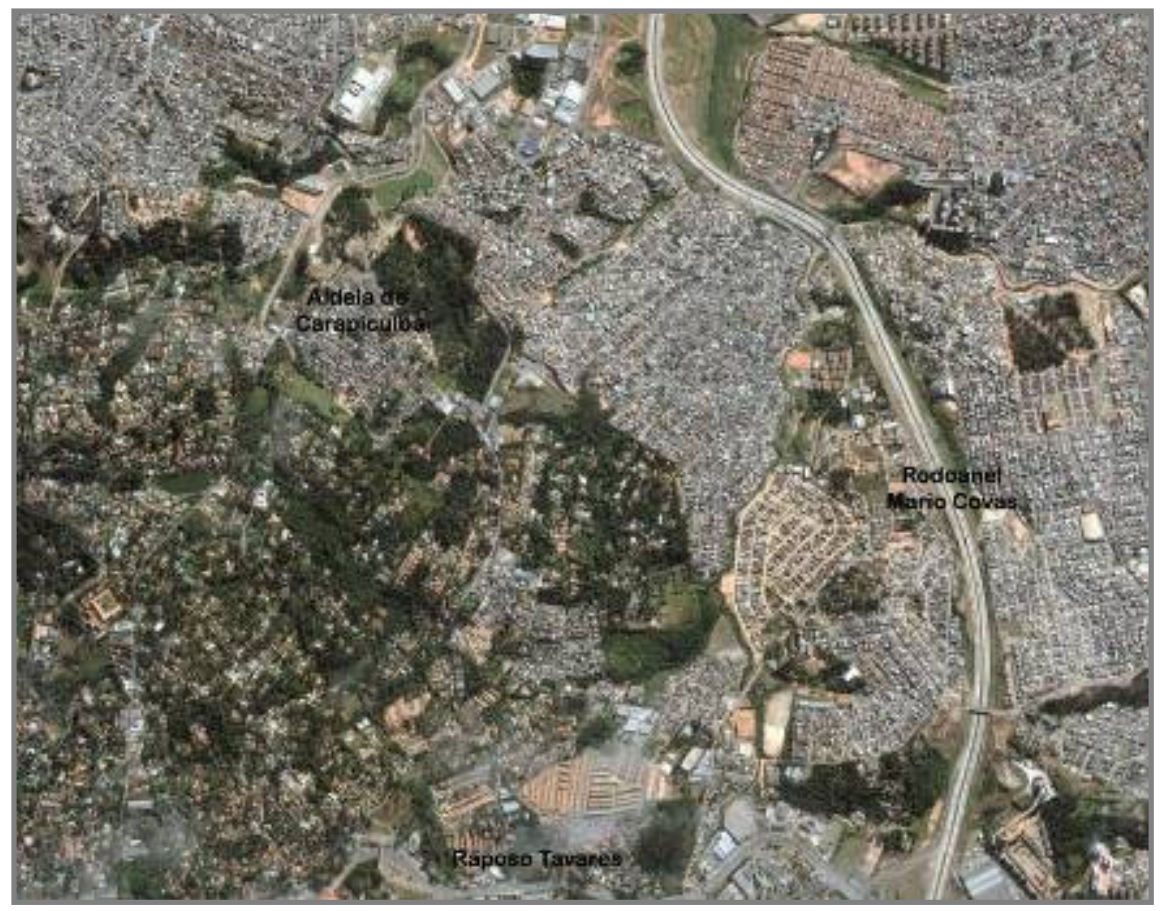

Fiqura 65 - Vista aérea parcial de Carapicuíba. Fonte: Gooqle Earth, 2007. 


\subsection{0 entorno da Aldeia de Carapicuíba}

Há algumas décadas, o terreiro secular da Aldeia de Carapicuíba ocupava a área rural do município, era rodeado por sítios produtores de hortifrutigranjeiros, mas hoje está inserida em contexto residencial de caráter popular, que conta com algumas pequenas indústrias, unidades de comércio e serviços e chácaras de lazer.

A região foi totalmente pressionada pela intensa ocupação urbana típica de periferia, cujo agravante culminou com a implantação da Rodovia Castelo Branco nos anos 60 ("boom" industrial e na época, novo e principal acesso ao oeste e sudoeste paulista) e, mais recentemente, com o trecho oeste do Rodoanel Mario Covas em 2002. 

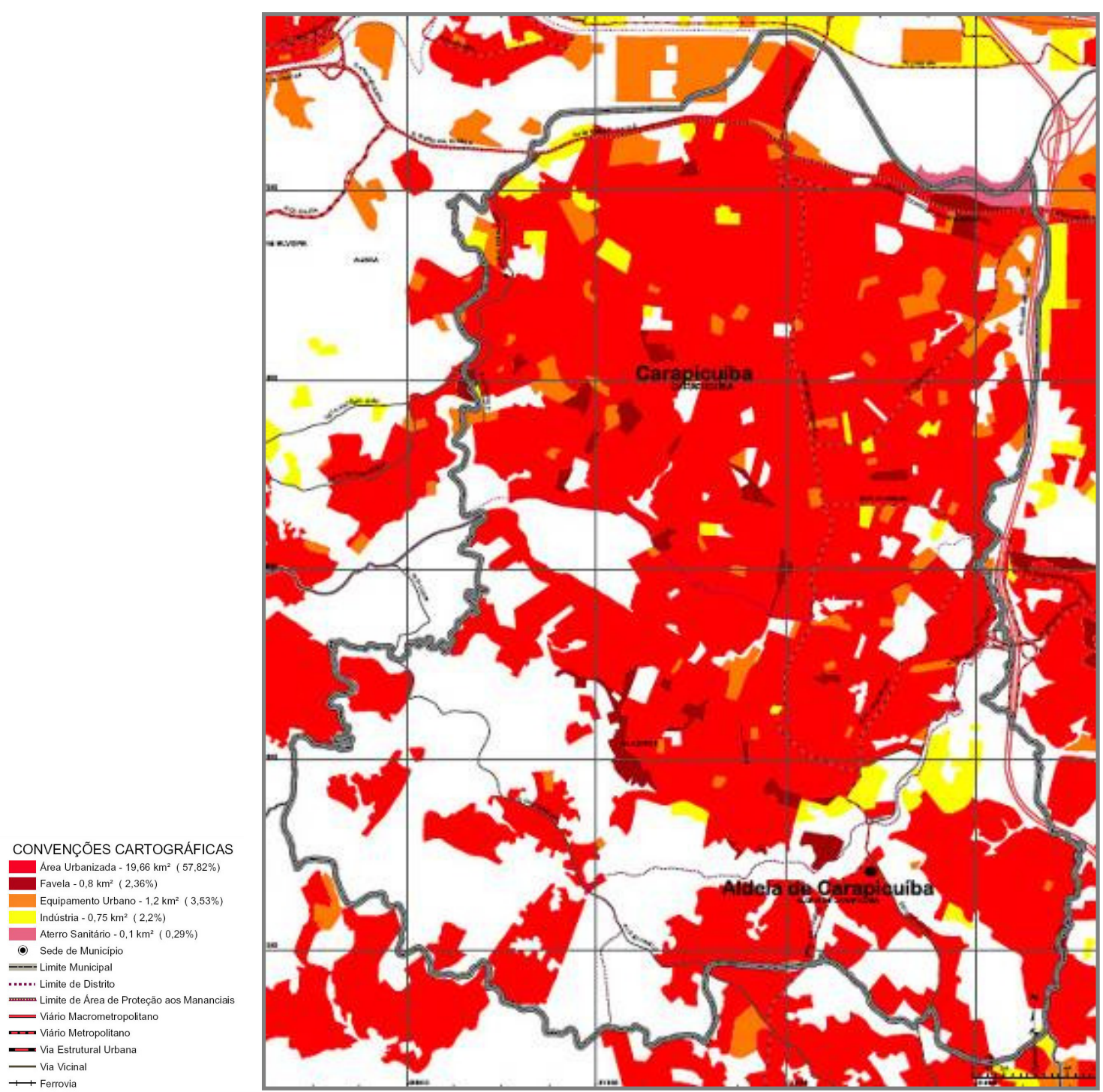

Figura 66 - Uso e Ocupação do Solo de Carapicuíba - Uso Urbano. Fonte: EMPLASA, 2006. 
A interpretação do mapa de Uso e Ocupação do Solo do município confirma a sua intensa ocupação. Chama a atenção o avanço da área urbanizada na região da Aldeia de Carapicuíba, além da presença de área de favela e indústria.

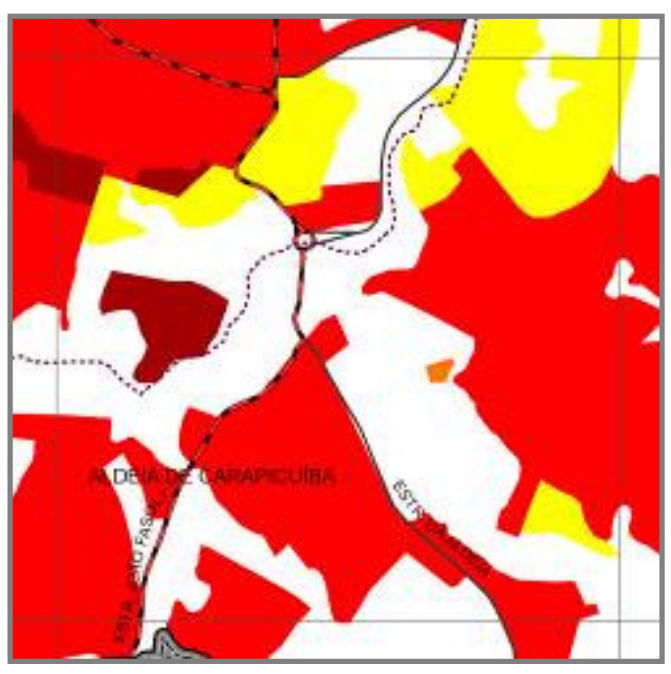

CONVENÇÕES CARTOGRÁFICAS Area Urbanizada - $19,66 \mathrm{~km}^{2}$ ( $\left.57,82 \%\right)$ Favela $0,8 \mathrm{~km}^{2}(2,36$ Aterro Sanitário $-0.1 \mathrm{~km}^{2}(0,29 \%)$ - Sede de Municipio ...... Limite de Distrito

\section{m...m Limite de Área de Prot}

V Viário Macrometropolitano

- Via Vicinal

Figura 67 - Uso e Ocupação do Solo de Carapicuíba - Uso Urbano. Detalhe da região da Aldeia de Carapicuíba. Fonte: EMPLASA, 2006.

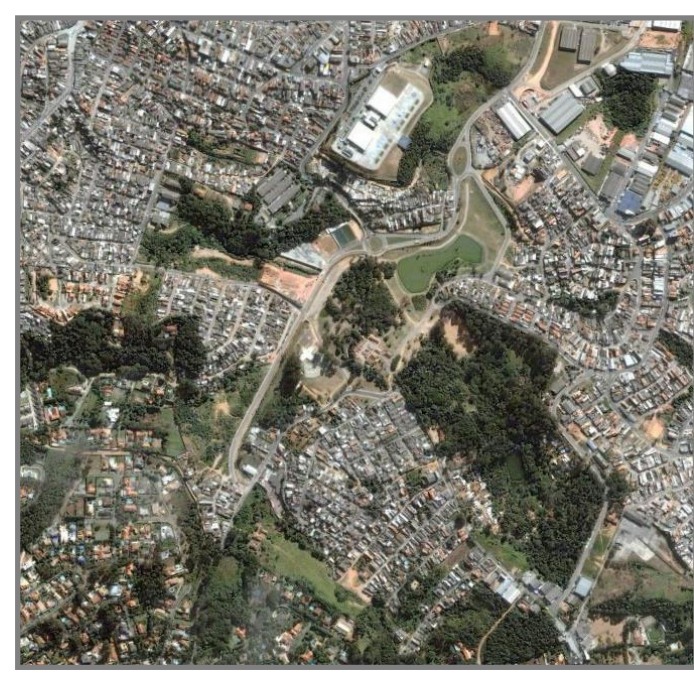

Figura 68 - Uso e Ocupação do Solo de Carapicuíba - Uso Urbano. Detalhe da região da Aldeia de Carapicuíba. Fonte: EMPLASA, 2006. 


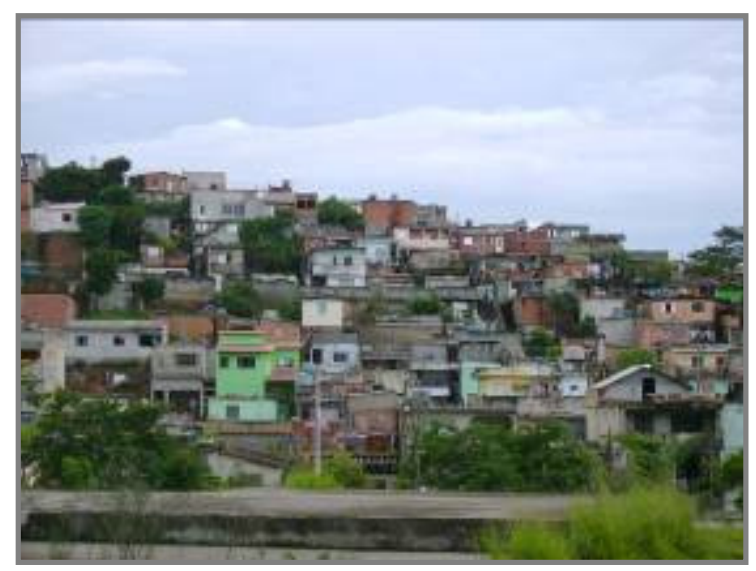

Figura 69 - 0 entorno - face nordeste, Jd. Lice. Fonte: arquivo pessoal, 2008.

Neste levantamento, a EMPLASA classifica favela como 0 "conjunto de unidades habitacionais e sub-habitacionais (barraco, casas de madeira ou alvenaria), sem identificação de lotes, dispostas, via de regra, de forma desordenada e densa. 0 sistema viário é constituído por vias de circulação estreitas e de alinhamento irregular. As favelas que passaram por processo de urbanização foram incluídas como área urbanizada”. 


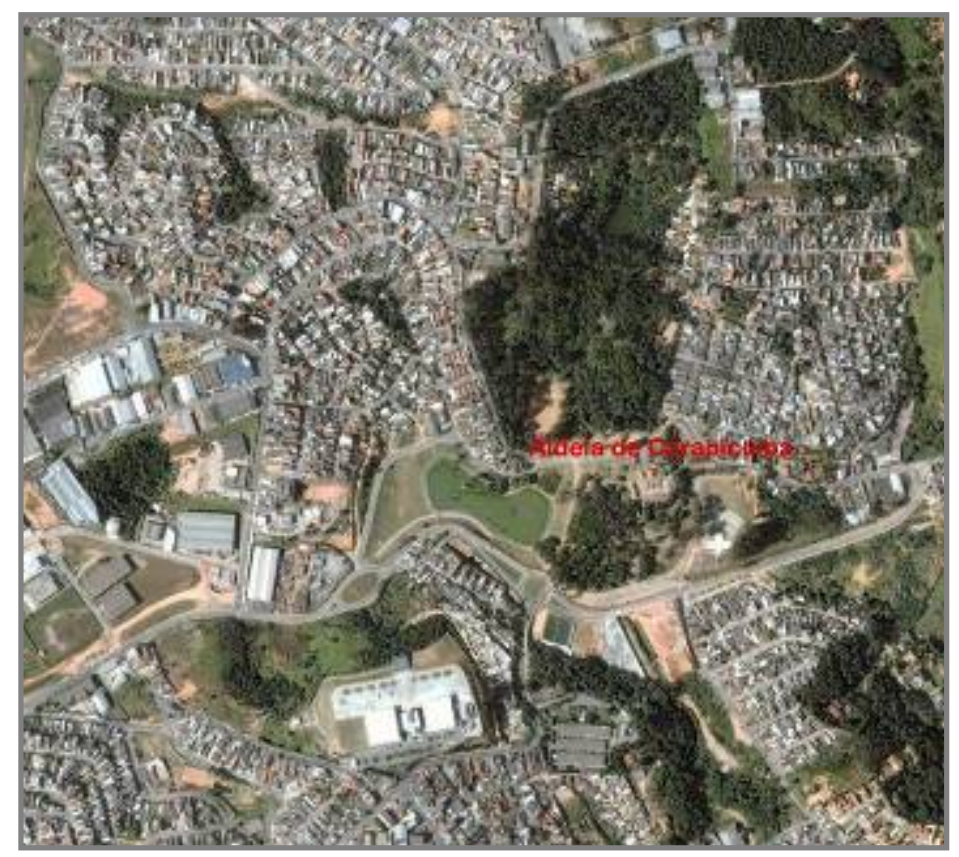

Figura 70 - Vista aérea parcial da Aldeia de Carapicuíba e 0 entorno. Fonte: Google Earth, 2007.

Já Área Urbanizada, define como sendo: "áreas arruadas e efetivamente ocupadas por usos residencial, comercial e de serviços, caracterizadas por ruas e edificações. Foram considerados: quadras parcial e totalmente ocupadas, condomínios de prédios construídos e em construção, garagens de ônibus, supermercados, postos de gasolina, shopping centers, etc." 
E Equipamento Urbano como "área ocupada por estabelecimentos, espaços ou instalações destinados à educação, saúde, lazer, cultura, assistência social, culto religioso ou administração pública". A vegetação foi identificada como tipo, portanto não foi incluída.

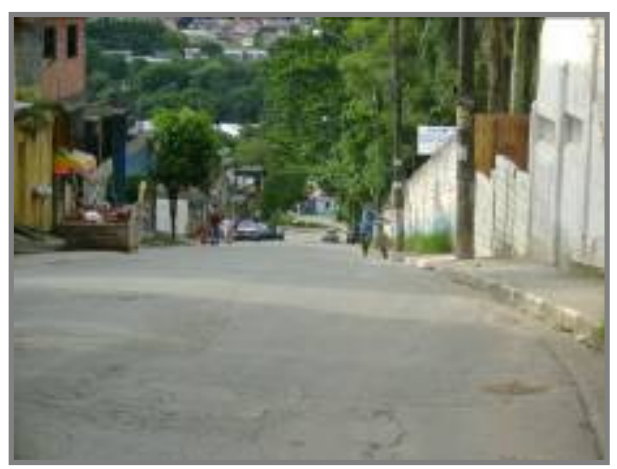

Figura 71 - 0 entorno - Vista da estrada da Aldeia, muros do antigo Sanatório Anhembi e a Aldeia no fundo. Fonte: arquivo pessoal, 2008.

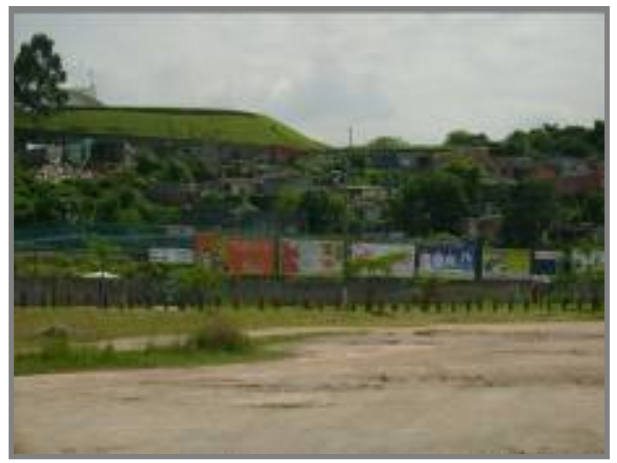

Figura 73 - Vista da rua Marginal. Fonte: arquivo pessoal, 2008.

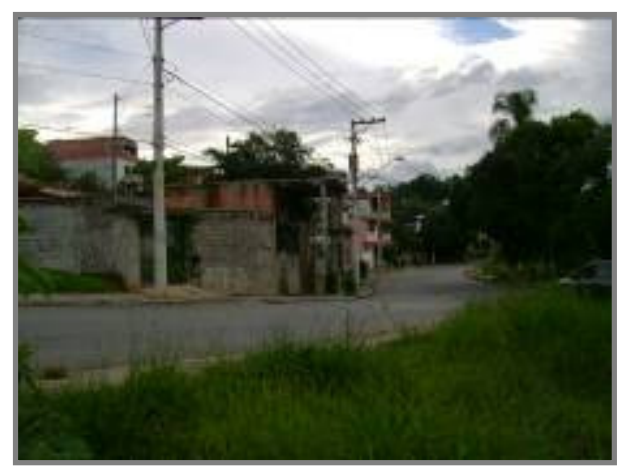

Figura 72 - Vista a partir da estrada João Fazoli. Fonte: arquivo pessoal, 2008.

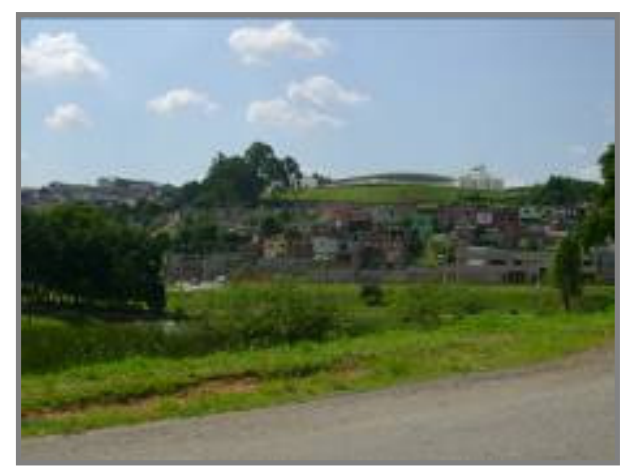

Figura 74 - Vista do desvio da aldeia para 0 parque. Fonte: arquivo pessoal, 2008. 
Desde 1970, a Aldeia faz parte do perímetro urbano de Carapicuíba e assim, com a explosão da urbanização aliada à inexistência de um Plano Diretor e mais a falta de responsabilidade dos políticos da época, a exploração imobiliária estendeu-se no limite de 300 metros determinados pela lei de tombamento e preservação. Além disso, essa ocupação rápida e desordenada provocava também a insuficiência de infra-estrutura para atender a grande demanda. 
Em oposição ao ambiente de periferia, apresenta como vizinho um bairro de classe média alta - Granja Viana - com terrenos de grandes áreas loteadas por condomínios e chácaras de lazer.

Através da análise do mapa, pode-se observar que a região da Aldeia de Carapicuíba é a praticamente a fronteira das áreas de chácaras existentes.
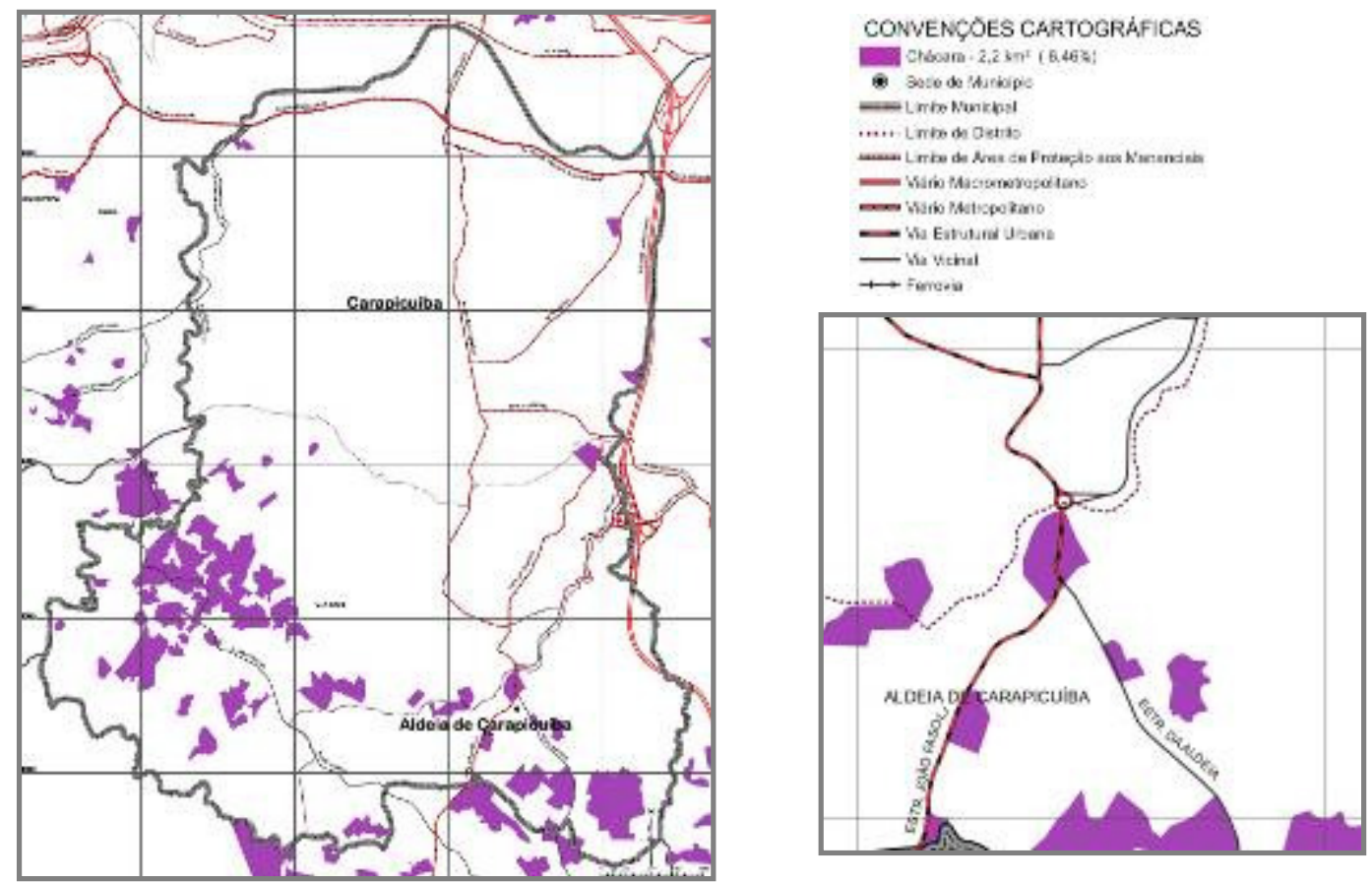

Figuras 75 e 76 - Uso e Ocupação do Solo de Carapicuíba e detalhe da região da Aldeia - Chácaras. Fonte: EMPLASA, 2006. 


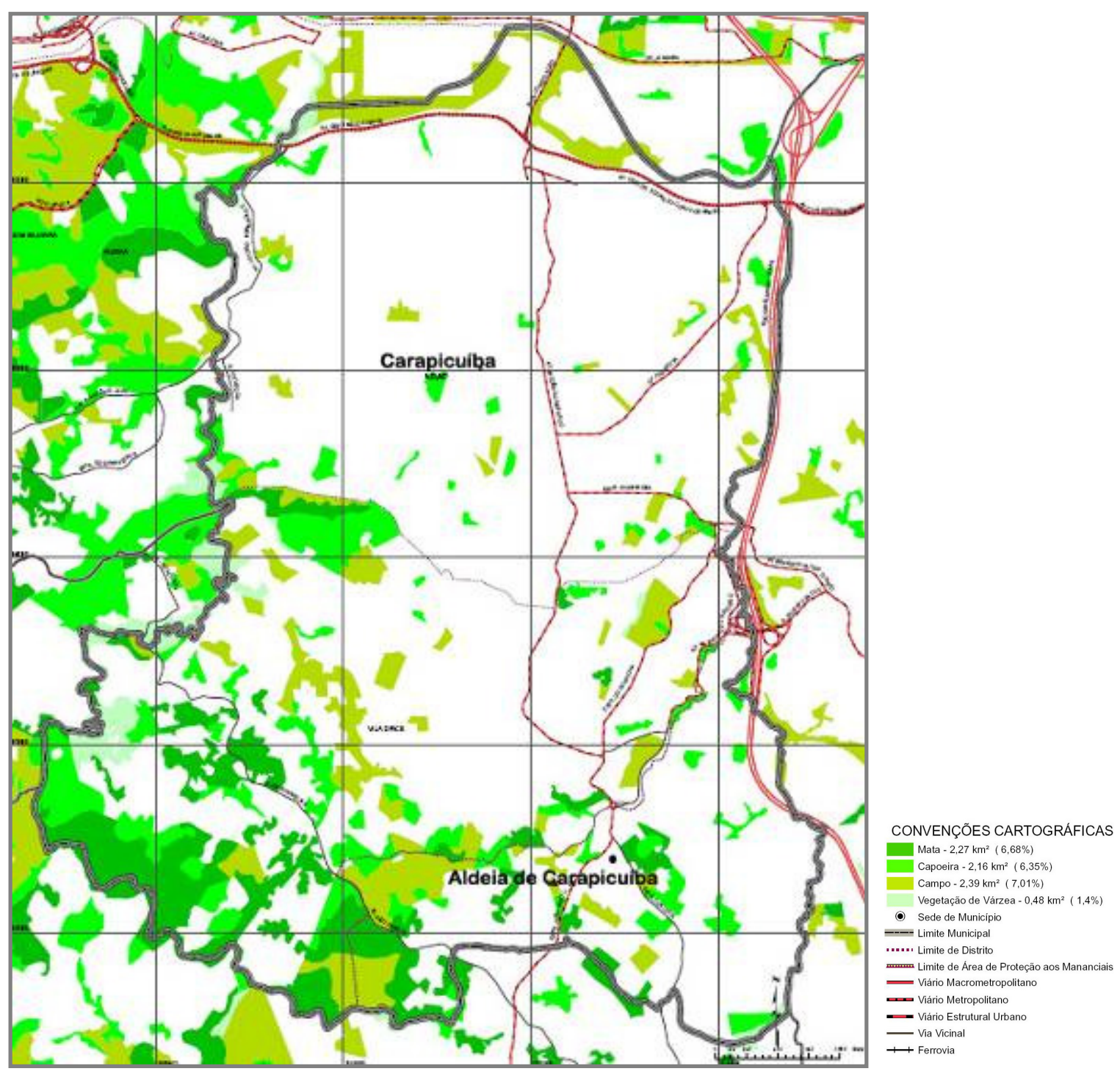

Figura 77 - Uso e Ocupação do Solo de Carapicuíba - Vegetação. Fonte: EMPLASA, 2006. 
Hoje, o entorno do Sítio Histórico da Aldeia de Carapicuíba ainda continua com ocupação típica de periferia, mas a criação do Parque Cultural da Aldeia, em 2002, atenuou o processo de avanço da malha urbana sobre o núcleo tombado. E a maioria das construções que avançavam o limite de 300 metros determinados pela lei de tombamento foram demolidas. 
Pela imagem do mapa, a área de mata (árvores superiores a 5 metros, cujas copas se toquem, ou cobertura de pelo menos $40 \%$ ) na região da Aldeia, se concentra mais nos terrenos da Chácara do Quiriri e em parte das instalações do Antigo Sanatório Anhembi.

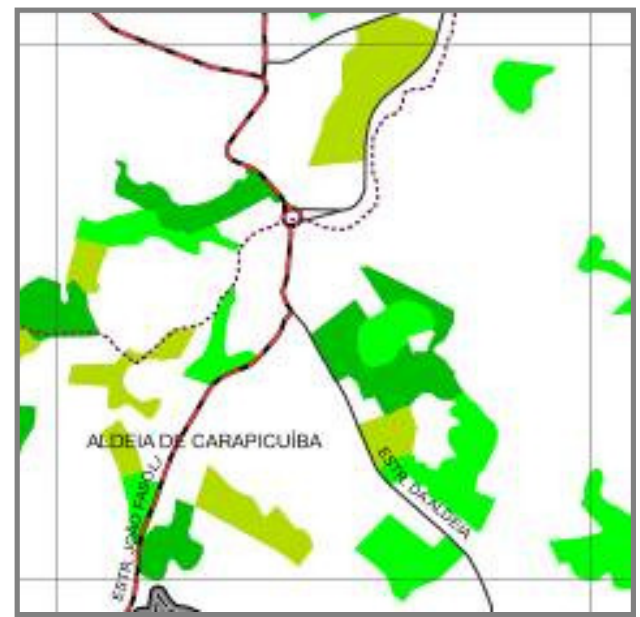

CONVENÇÕES CARTOGRÁFICAS

Mata- $-2,27 \mathrm{~km}^{2}(6,68 \%)$

Capoeira $-2,16 \mathrm{~km}^{2}(6,35 \%)$

Campo $-2,30 \mathrm{~km} 2(7,01 \%)$

- Sede de Municipio

...... Limite de Distrito

wmam Limite de Area de Proteçăo aos Mananciais

- Viário Macrometropolitano

WViário Metropolitano

—Via Vicinal

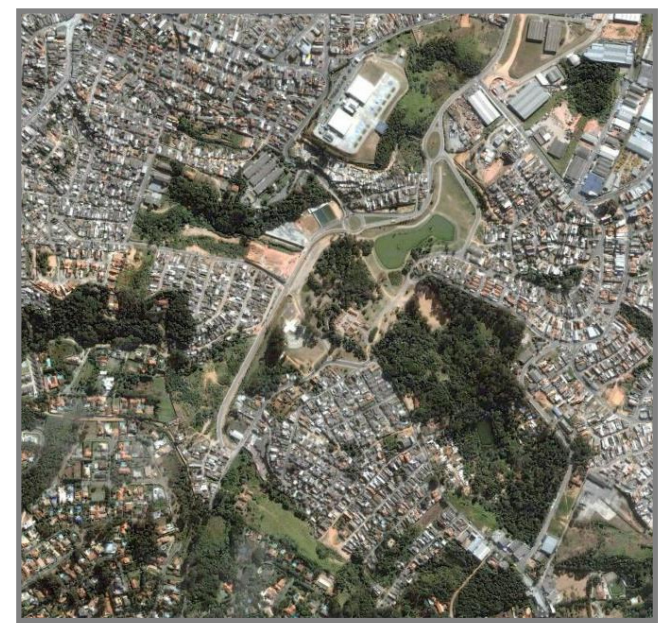

Figura 79 - Vista aérea do Parque e entorno. Fonte: Google Earth, 2007.
Figura 78 - Uso e Ocupação do Solo de

Carapicuíba Vegetação. Detalhe da região da Aldeia. Fonte: EMPLASA, 2006. 


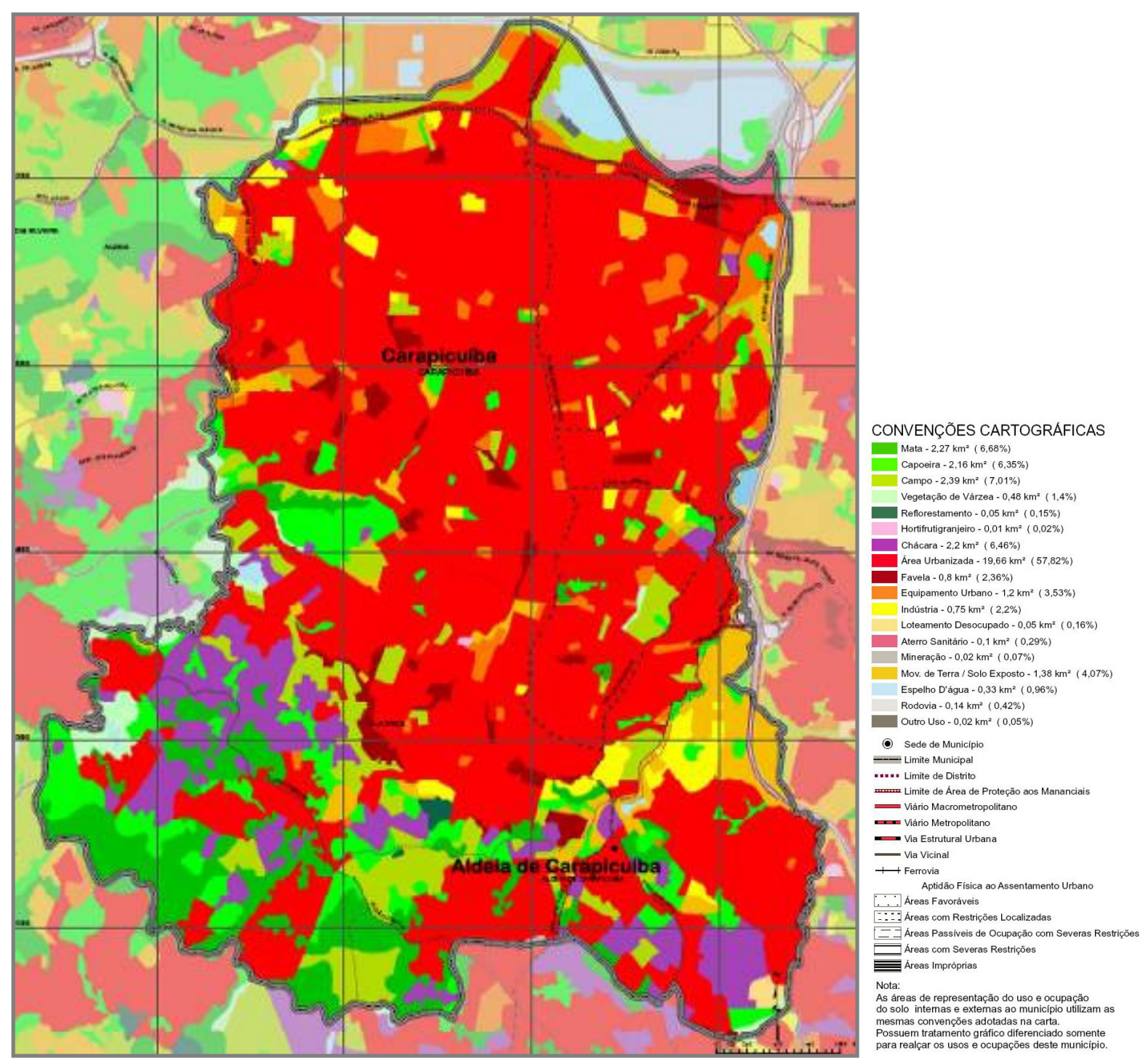

Figura 80 - Uso e Ocupação do Solo de Carapicuíba. Fonte: EMPLASA, 2006. 


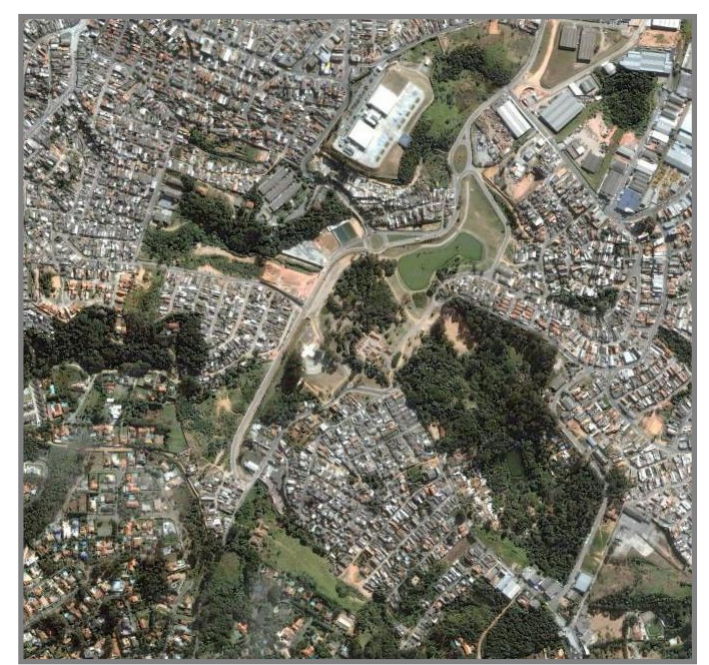

Figura 81 - Vista aérea do Parque e entorno. Fonte: Google Earth, 2007.

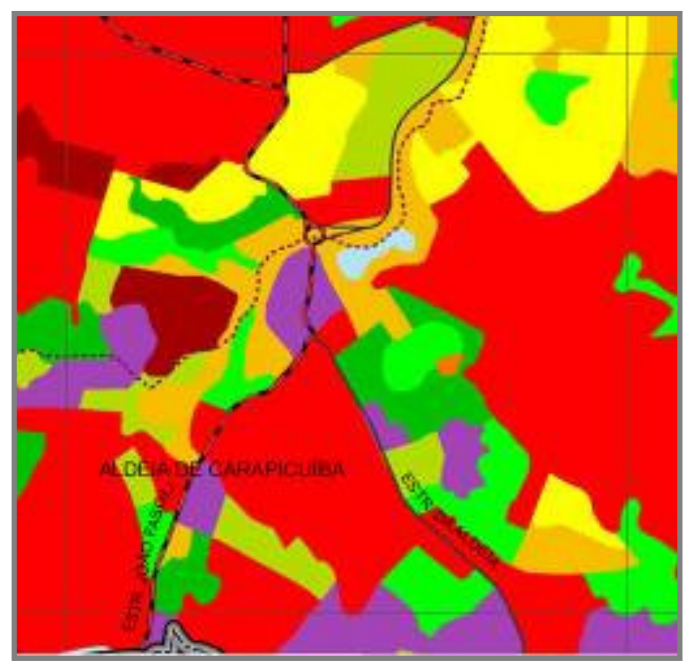

CONVENCOOES CARTOGR/FICAS

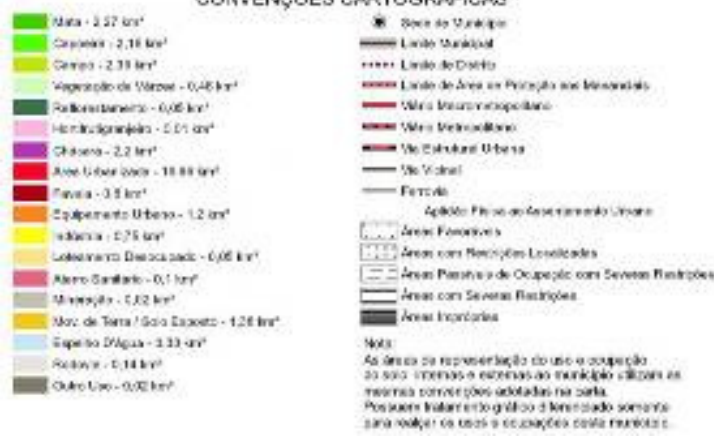

Figura 82 - Uso e Ocupação do Solo de Carapicuíba. Detalhe da região da Aldeia. Fonte: EMPLASA, 2006.

Já com o mapa geral de Uso e Ocupação do Solo pode-se ter um panorama completo da natureza dos usos do território de Carapicuíba. 


\subsubsection{Implantação do Trecho Oeste do Rodoanel e consequências}

0 Trecho Oeste do Rodoanel tem $32 \mathrm{~km}$ de extensão e "atravessa uma complexa multiplicidade de universos históricos e sociais" (ROBRAHN-GONZALES, 2006, p.171). Vai da estrada Velha de Campinas, zona norte de São Paulo, até a Rodovia Regis Bittencourt, no município de Embu. Passa pelas rodovias Bandeirantes, Anhanguera, Castelo Branco e Raposo Tavares. Desse modo, cruza as cidades de São Paulo, Barueri, Carapicuíba, Osasco, Cotia e Embu.

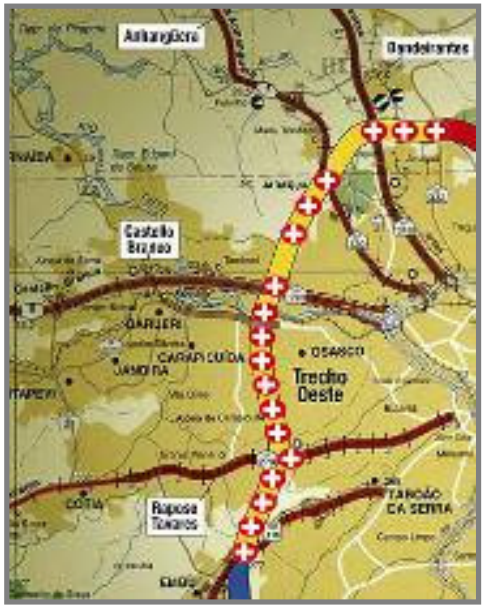

Figura 83- Trecho Oeste do Rodoanel Mario Covas. Fonte Dersa, 2002.

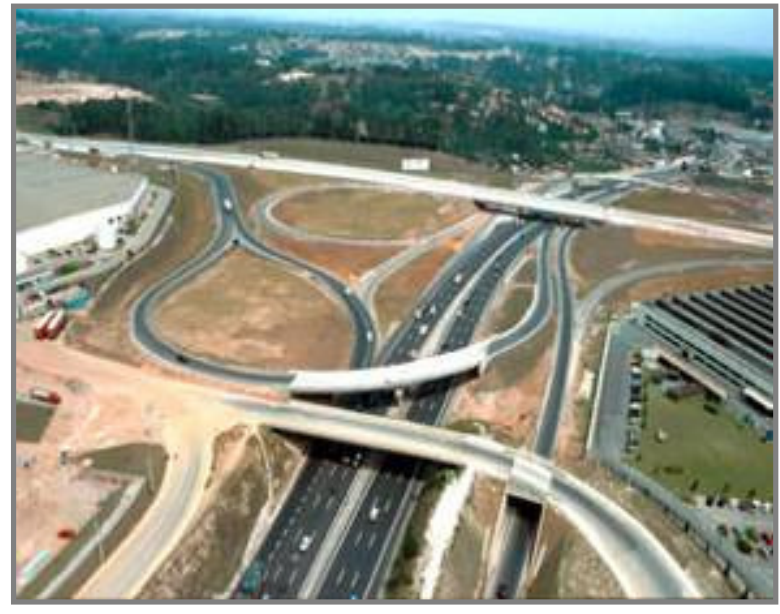

Figura 84- Encontro do Rodoanel com a Rodovia Raposo Tavares, em Carapicuíba. Fonte Dersa, 2002. 
Para empreendimentos de infra-estrutura do porte do Rodoanel, a lei federal 6.938/81 (Política Nacional do Meio Ambiente) e a resolução CONAMA nº 001 de 1986 exige estudos e relatórios de impacto ambiental (EIAs/RIMAs). Sendo assim, é necessária, antes da implantação do projeto, a realização de um diagnóstico ambiental que leva em conta o meio físico, o meio biológico e ecossistemas naturais e também o meio socioeconômico.

Mas as obras do Rodoanel Trecho Oeste foram iniciadas sem os estudos preventivos, resultando na assinatura de um Termo de Ajustamento de Conduta devido ao processo que 0 IPHAN abriu junto ao Ministério Público Federal. Assim, foi elaborado por uma equipe multidisciplinar o Programa Arqueológico do Rodoanel Metropolitano de São Paulo. De acordo com Robrahn-Gonzales, (2006, p.171) 0 referido programa foi voltado à "identificação, dimensionamento e valoração científica do patrimônio arqueológico existente no trajeto da rodovia, tendo como objetivo último a apresentação de soluções de tratamento que permitissem recuperar seu conteúdo informativo"..$^{39}$

\footnotetext{
${ }^{39}$ Para mais informações GONZALEZ-ROBRAHN, Erika Marion. 0 Programa Arqueológico do Rodoanel Metropolitano de São Paulo Trecho Oeste: ciência, preservação e sustentabilidade social. São Paulo: 9åR/IPHAN, 2006.
} 
Apresenta, ainda, como premissa identificar e caracterizar as diversas culturas que ocuparam a região e sua relação a contextos históricos e arqueológicos de caráter macroregional. E Robrahn-Gonzales (2006, p.172) confirma que

[...] a abordagem envolveu a identificação e inserção geográfica, ambiental e temporal dos sítios arqueológicos da área, assim como o resgate e estudo dos remanescentes de cultura material a eles associados, testemunhos do conjunto de sociedades humanas que habitaram a região[...].

Por meio do Programa, foi explicitado que as comunidades não se identificavam culturalmente com os vínculos do passado, tinham baixo reconhecimento ao patrimônio ("bens velhos no meio urbano") e supervalorização do novo.

A Aldeia de Carapicuíba foi classificada como o mais antigo sítio histórico. Por meio do Programa, foi diagnosticado "porções remanescentes do terreno original, ligado à ocupação indígena e atuação jesuíta". Durante as prospecções identificaram-se 11 fragmentos cerâmicos, sendo que um deles com características da cerâmica Tupi-guarani.

Resultados

Como medida compensatória dos impactos negativos do Trecho Oeste do Rodoanel, desenvolveu-se um estudo de implantação de um programa integrado de visitação turística - 
Circuito Cultural (que inclui o restauro de sítios arqueológicos) e a criação do Museu de Arqueologia Regional Oeste (onde serão guardados elementos inéditos achados durante as prospecções do programa). Este último será implantado próximo à Aldeia de Carapicuíba, na área do antigo Sanatório Anhembi, que viabilizará a abertura dos muros para comunicar as alamedas internas com o parque, efetivando, assim, 0 uso e visitação da comunidade.

0 início da construção está previsto ainda para este ano, 2009, sendo que há negociações entre a Prefeitura de Carapicuíba, o Iphan e 0 Dersa, para que a administração fique sob responsabilidade do EMAE/USP.
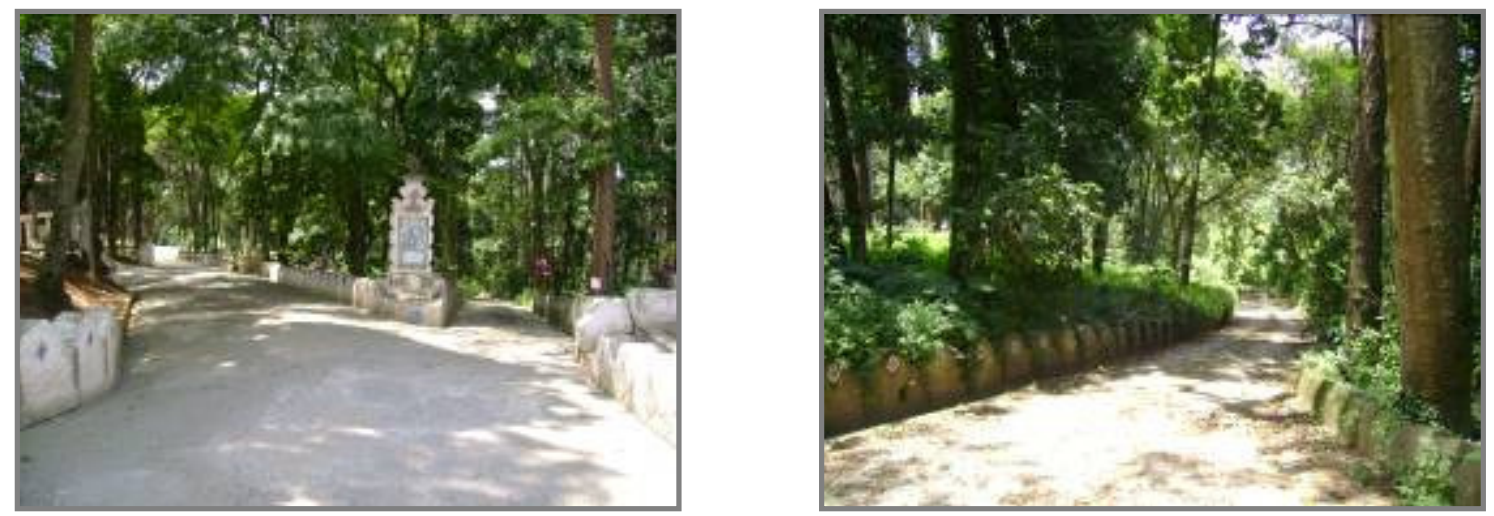

Figura 85 e 86 - Alamedas internas do antigo Sanatório Anhembi. Fonte: arquivo pessoal, 2008. 


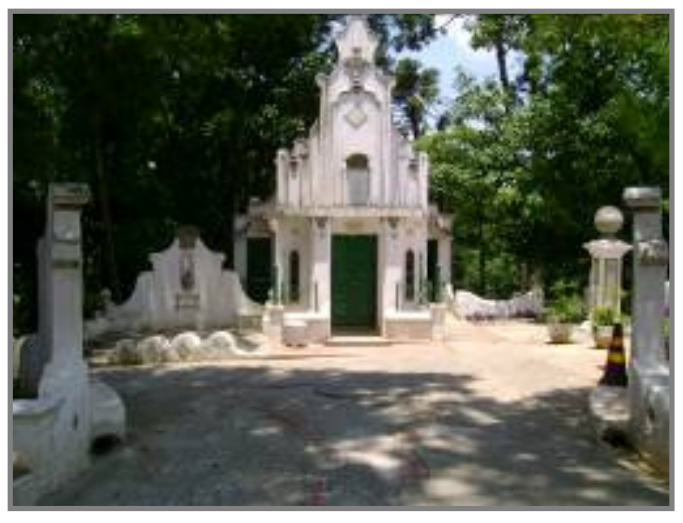

Figura 87- Capela - interior do antigo Sanatório Anhembi. Fonte: arquivo pessoal, 2008.

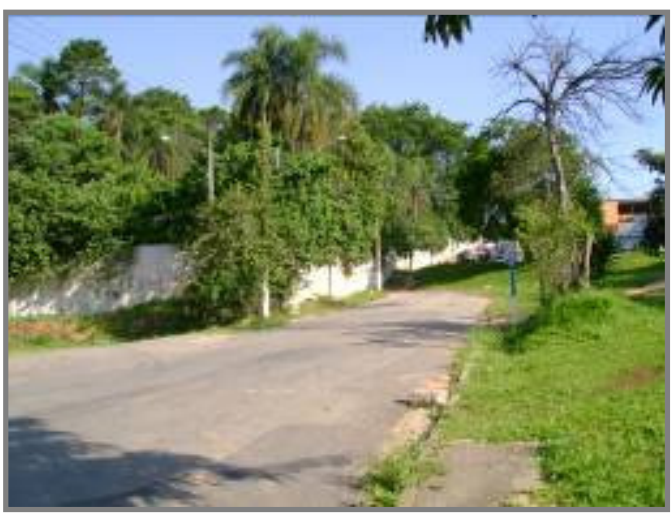

Figura 88 - Estrada da Aldeia, limite do antigo Sanatório Anhembi com a Aldeia de Carapicuíba. Fonte: arquivo pessoal, 2007. 


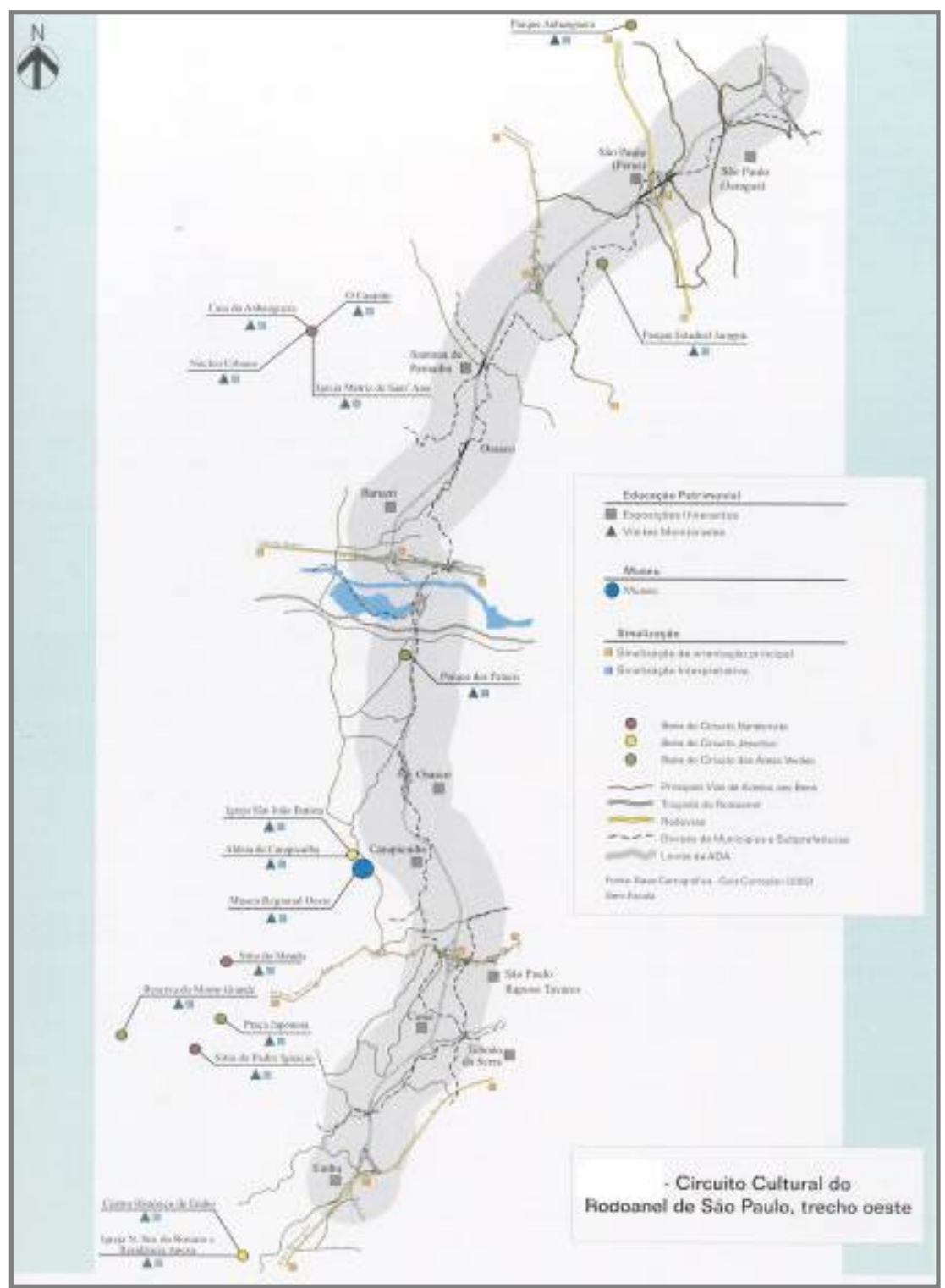

Figura 89- Mapa do Circuito Cultural do Rodoanel - trecho oeste. Fonte: Dersa, 2002. 


\subsection{Parque Cultural da Aldeia de Carapicuíba}

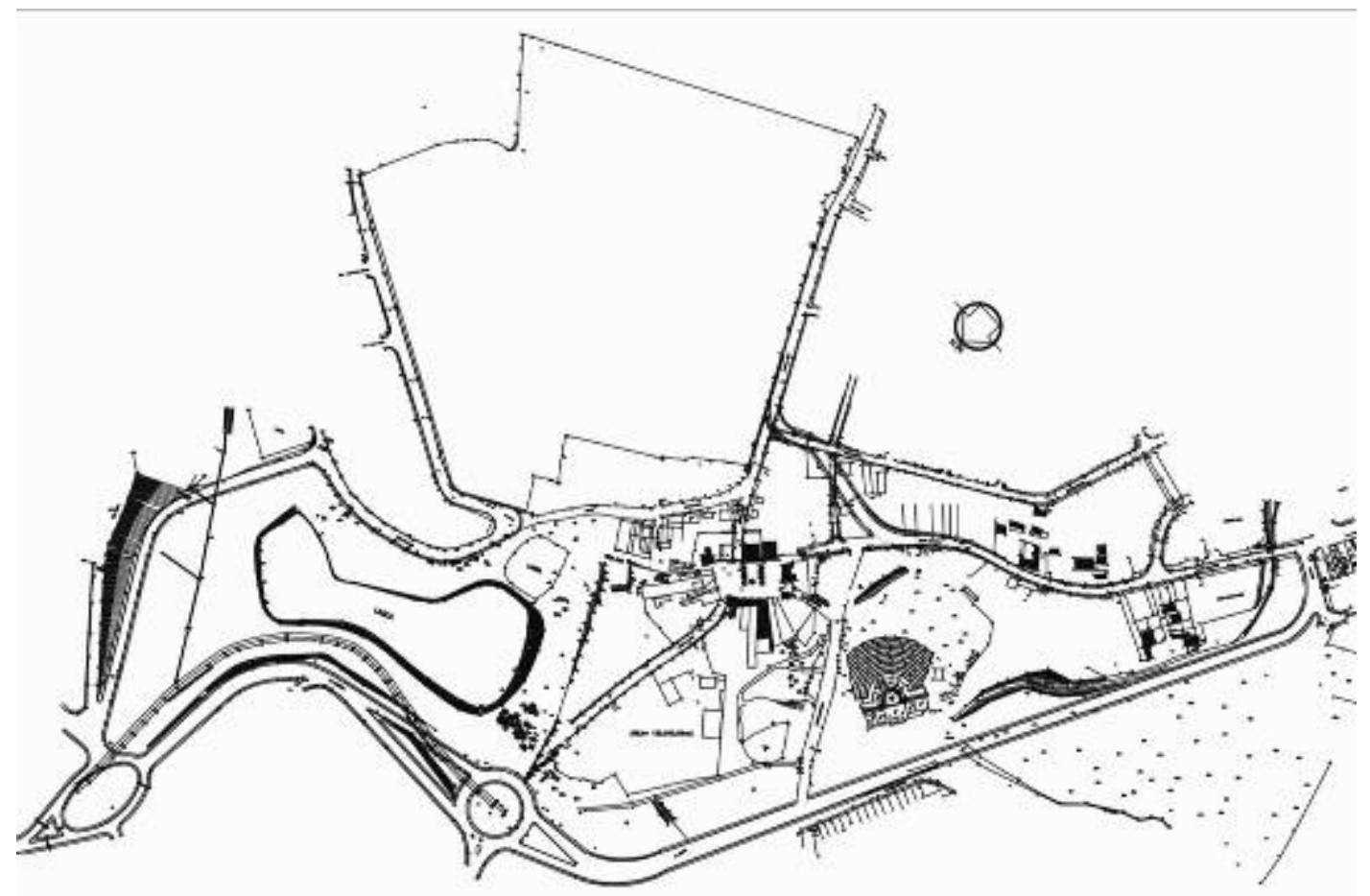

Figura 90 - Perímetro do Parque Cultural da Aldeia de Carapicuíba. Fonte: P.M. de Carapicuíba, 2001.

De iniciativa do governo municipal e com o objetivo de preservar a Aldeia de Carapicuíba e arredores, foi criado em 2002 o Parque Cultural da Aldeia de Carapicuíba. Seu perímetro inclui, além do núcleo da Zona de Preservação Histórica - ZPH (o quadrilátero jesuítico), 
também as áreas adjacentes como a área do antigo Sanatório Anhembi ${ }^{40}$, onde concentra a maior superfície de vegetação, totalizando, assim, área de quase $450.000 \mathrm{~m}^{2}$.

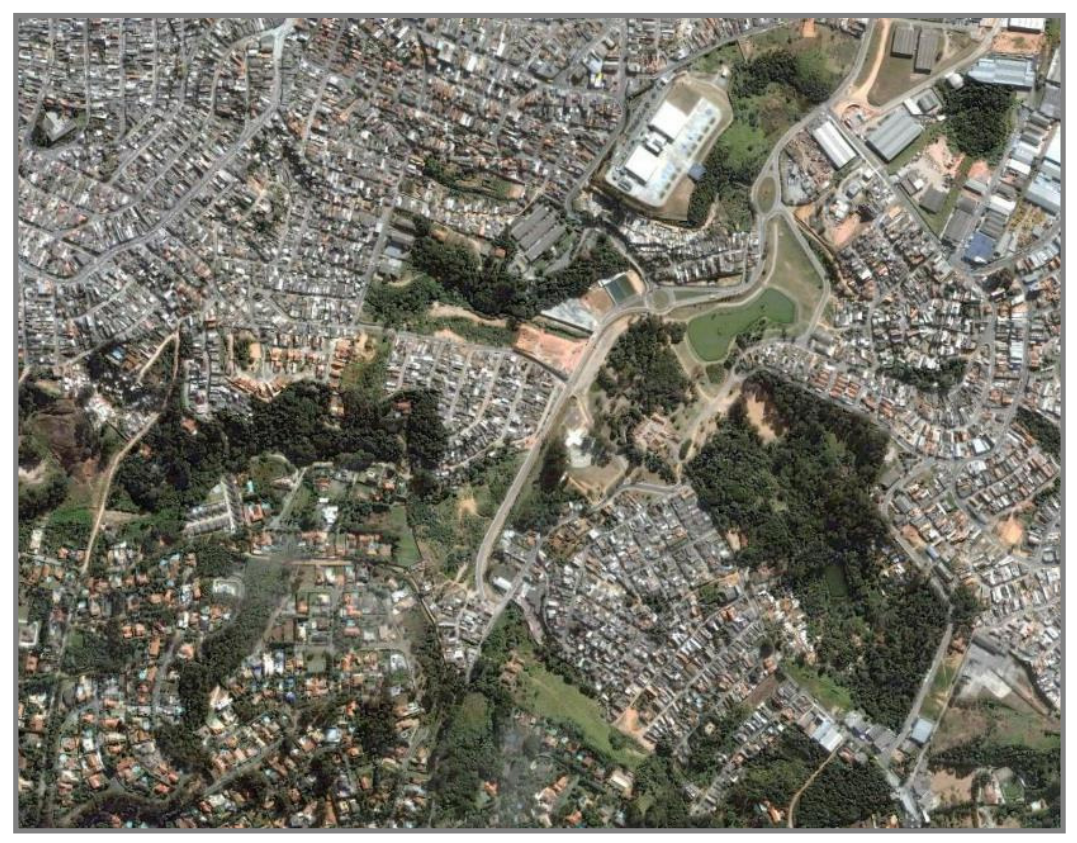

Figura 91 - Vista aérea do Parque e entorno. Fonte: Google Earth, 2007.

${ }^{40}$ As instalações do antigo Sanatório Anhembi hoje estão ocupadas por uma faculdade por regime de comodato. 
Ao envolver a região citada acaba por atenuar o impacto da malha urbana que, como todas as áreas periféricas da Grande São Paulo, cresce rápido e desordenadamente.

A implantação do Parque, além de preservar e valorizar o patrimônio básico e fundamental, possui grande significado pela efetiva e extensa utilização pela comunidade do entorno e região.

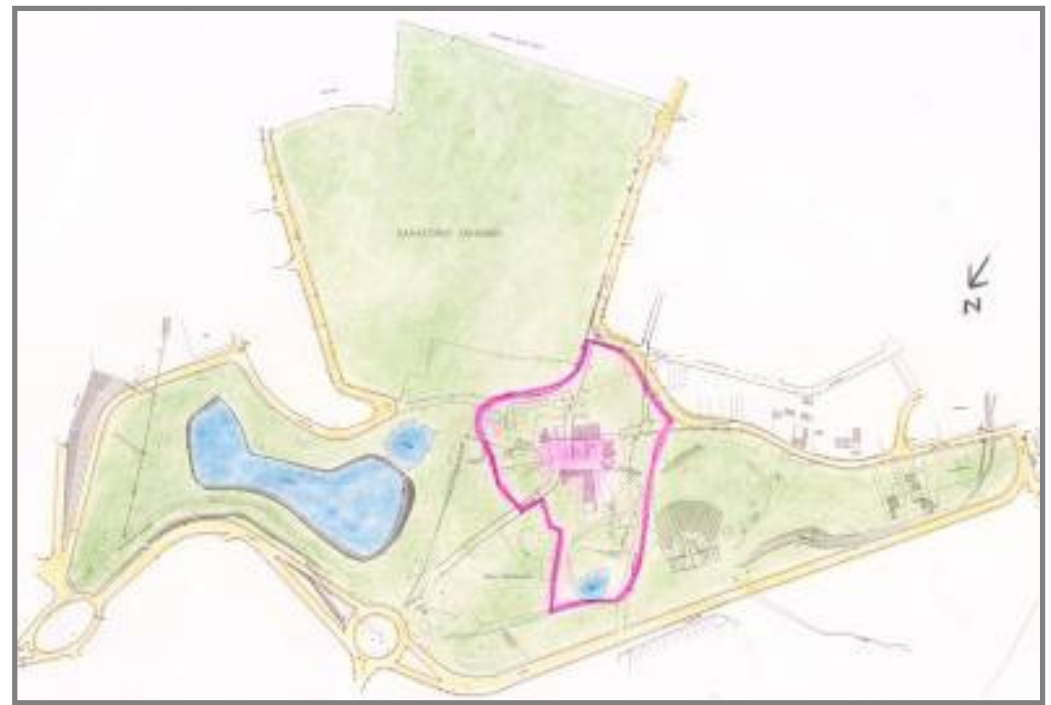

Figura 92 - Implantação do Parque Cultural da Aldeia de Carapicuíba. Fonte arquivo pessoal e P.M. Carapicuíba. 


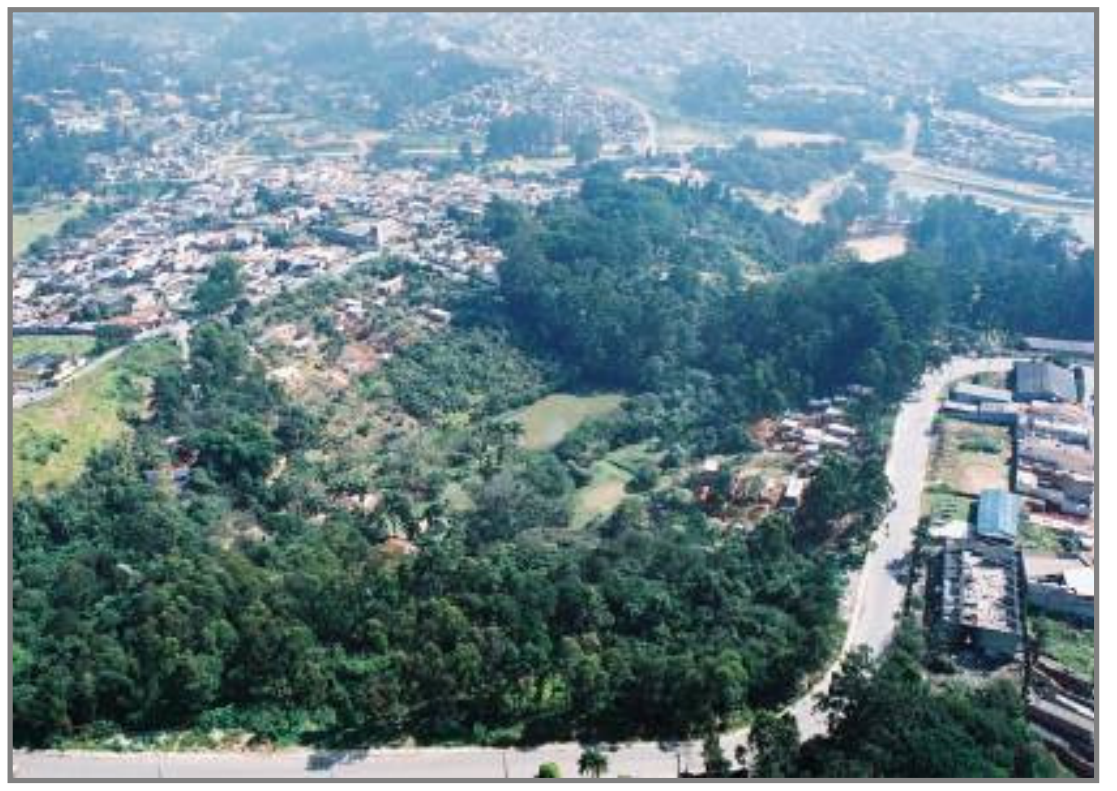

Figura 93 - Vista aérea parcial do Parque e áreas do antigo Sanatório Anhembi. E Chácara Quiriri. Fonte: P.M. de Carapicuíba.

Figura 97 - Vista aérea do Parque da Aldeia de Carapicuíba. Fonte: Google Earth, 2007.

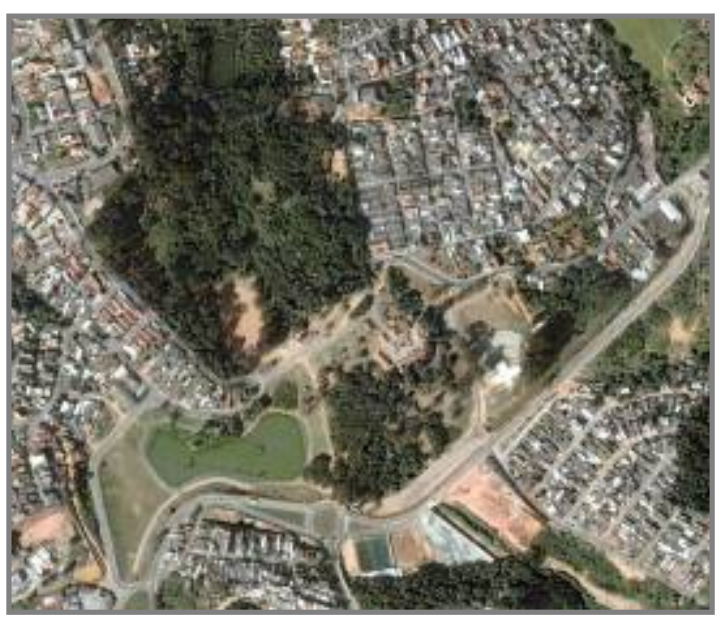




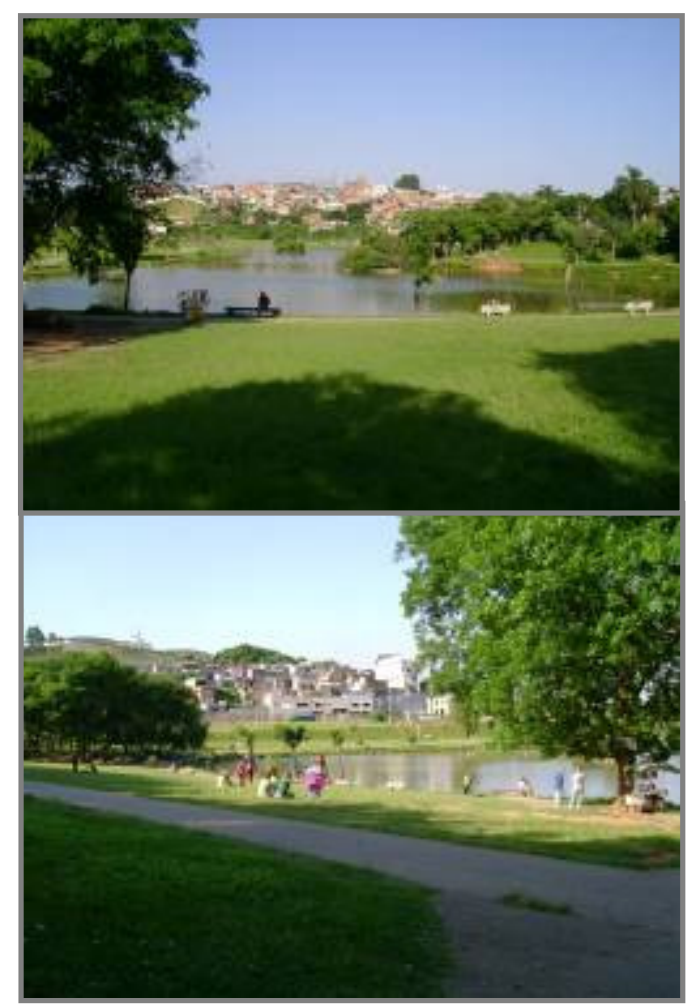

Figura 95 e 96 - Vistas do Parque da Aldeia de Carapicuíba. Fonte: Arquivo pessoal, 2009.

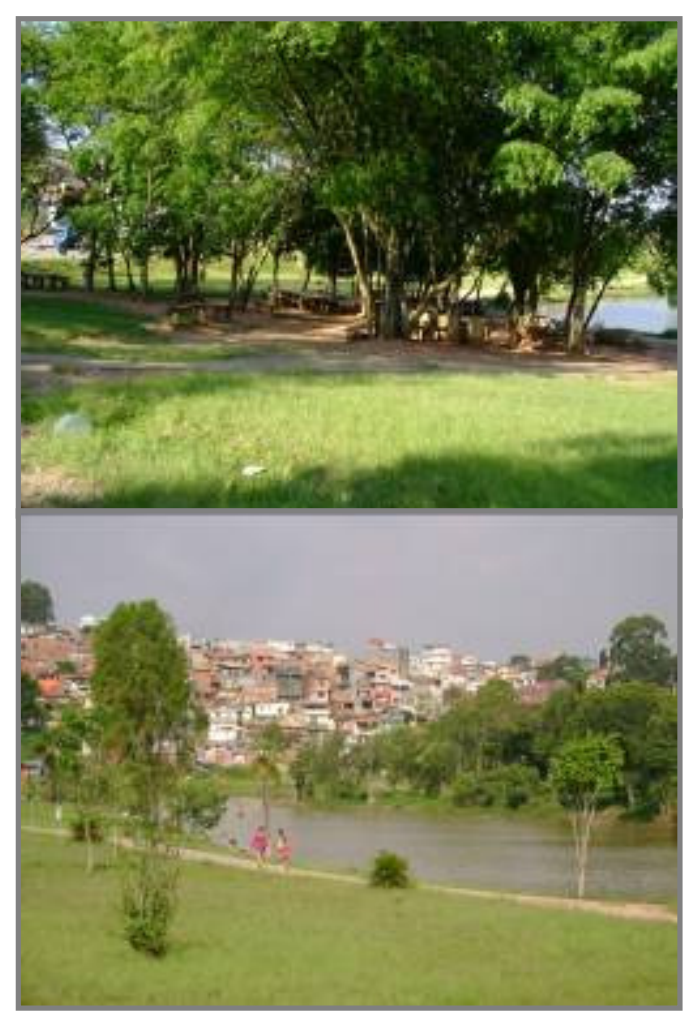

Figura 97 e 98 - Vistas do Parque da Aldeia de Carapicuíba. Fonte: Arquivo pessoal, 2009. 


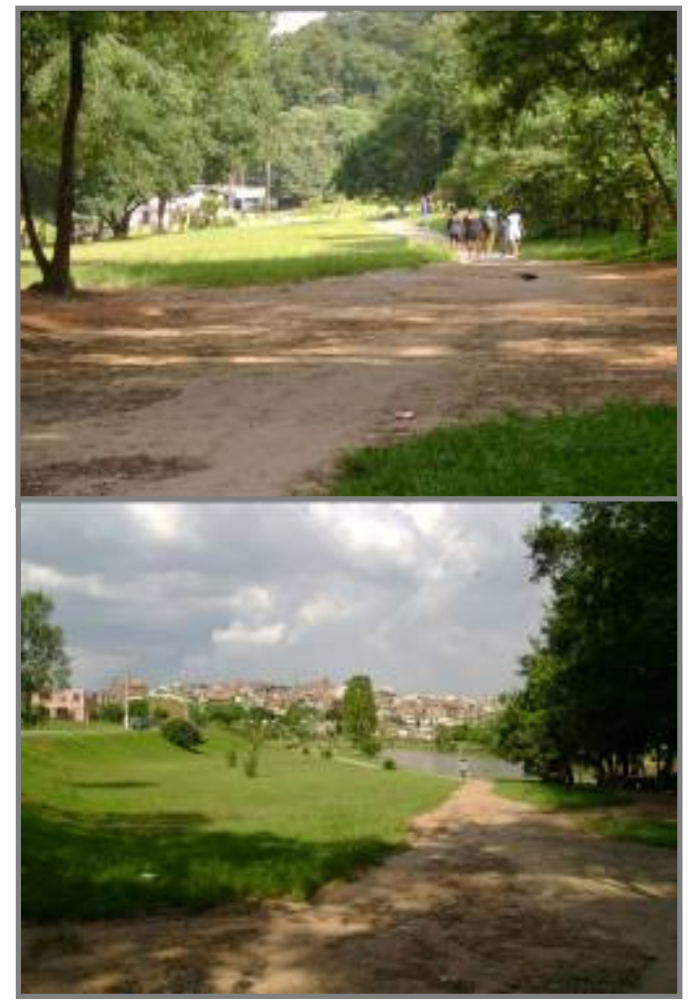

Figura 99 e 100 - Vistas do Parque da Aldeia de Carapicuíba. Fonte: Arquivo pessoal, 2009.

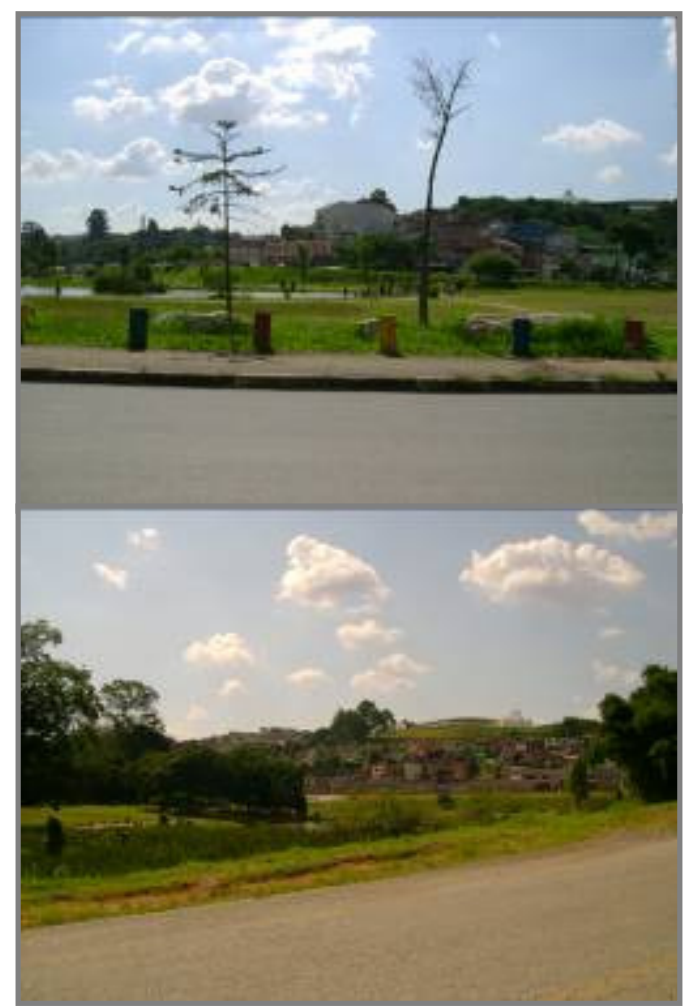

Figura 101 e 102 - Vistas do Parque da Aldeia de Carapicuíba. Fonte: Arquivo pessoal, 2009.

Mas, apesar do grande uso do Parque pela comunidade, esta, ainda está em processo de reconhecimento e apropriação efetiva da área como bem comum. Acredita-se que essa 
apropriação se estenda também para o quadrilátero da Aldeia, e deste modo materializa-se as novas vinculações de interesses e conseqüentemente de novos usos. 


\subsection{Terreiro da Aldeia hoje: uso e ocupação atual}

Nos dias atuais, pode-se dizer que a Aldeia de Carapicuíba é uma discreta mancha no contexto urbano do município. Sobrevive, pressionada em todo perímetro, pela desordenada e intensa ocupação de periferia, e oposto ao ambiente de periferia é vizinha da Granja Viana bairro de classe média alta, configurado por grandes terrenos loteados com condomínios e chácaras de lazer.

0 pequeno fragmento da história da colonização brasileira, tombado pelo IPHAN em 1940, sofre com a decadência da região, acentuada com a implantação da Rodovia Castelo Branco nos anos 60 e recentemente com o trecho oeste do rodoanel viário Mario Covas em 2002.

Tal processo revela como conseqüência a alteração dos usos e funções das antigas construções do quadrilátero, na maioria das vezes, com incompatíveis adaptações que ferem e descaracterizam a tradicional arquitetura. 
Apesar dos esforços do Iphan, desde o estudo de Luis Saia - elaborado em 1936 quando ainda era assistente de Mário de Andrade, e também de grupos de profissionais da comunidade local e da prefeitura de Carapicuíba - a Aldeia ainda sofre com a indefinição de suas funções e usos e almeja efetiva e real valorização.

Segue a implantação do pátio da Aldeia com a ocupação e uso atual. 


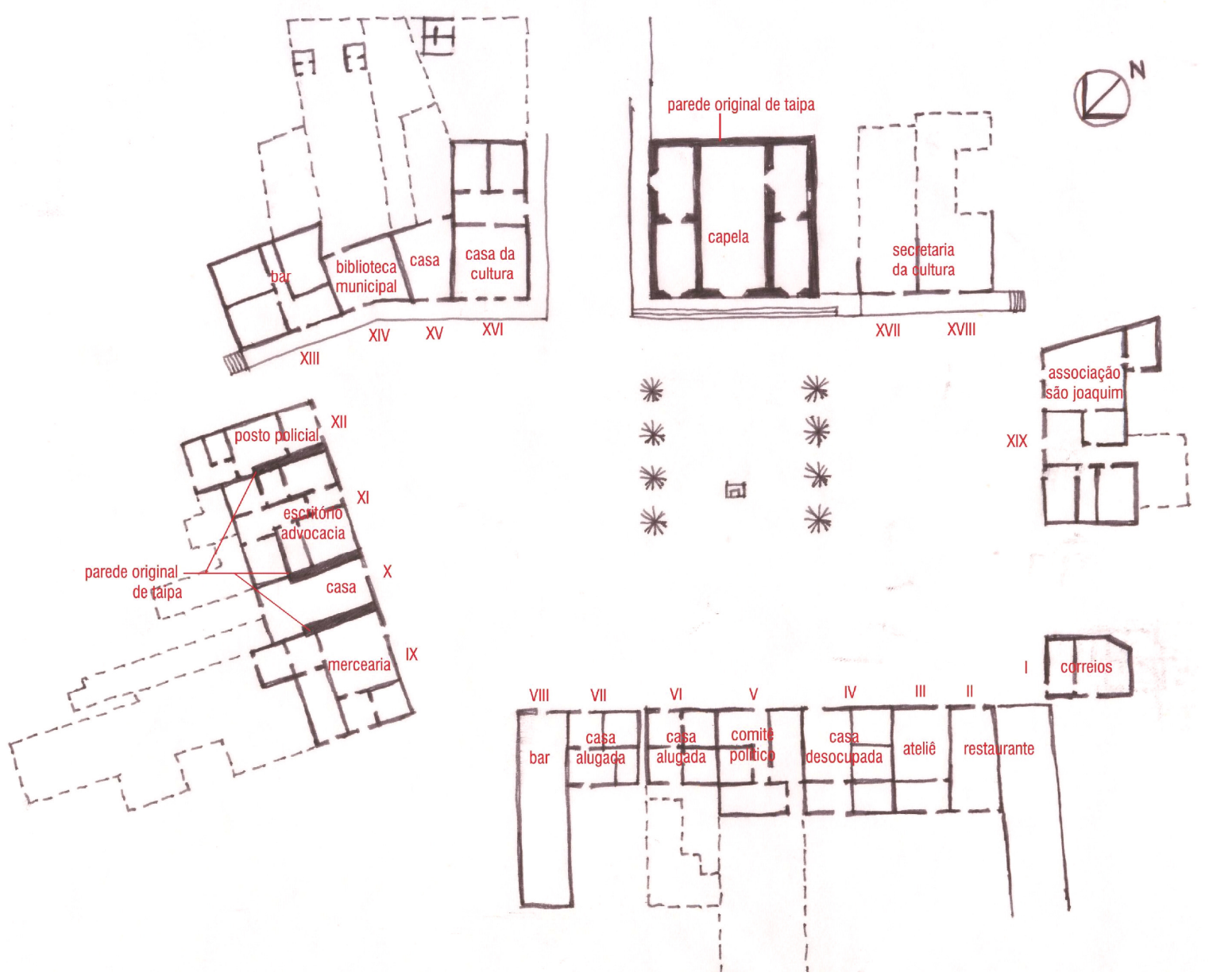

Figura 103 - Croqui da Implantação da Aldeia - uso e ocupação atual. Fonte: arquivo pessoal, 2007. 


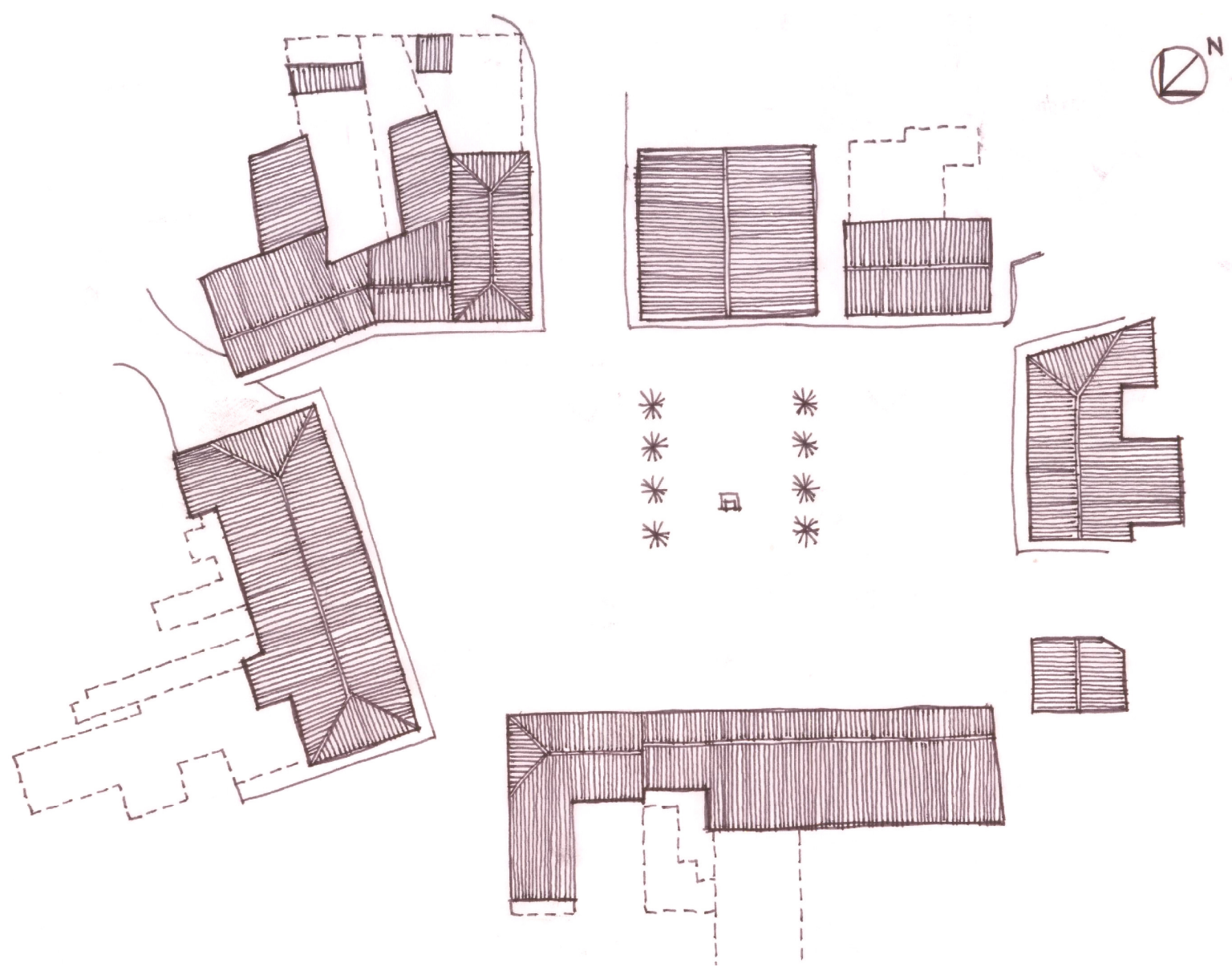

Figura 104 - Croqui da Implantação da Aldeia - uso e ocupação atual - Cobertura. Fonte: arquivo pessoal, 2007. 


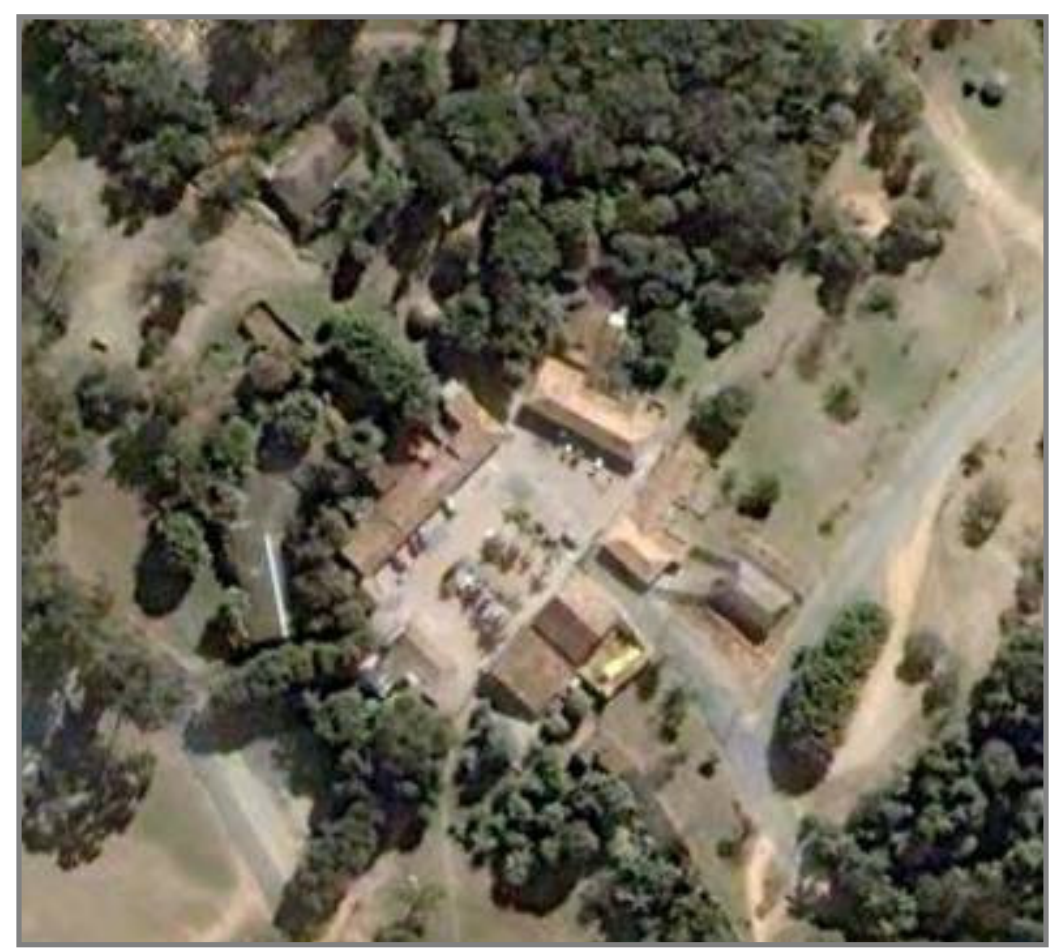

Figura 105 - Imagem aérea do quadrilátero da Aldeia. Fonte: Google Earth, 2008. 

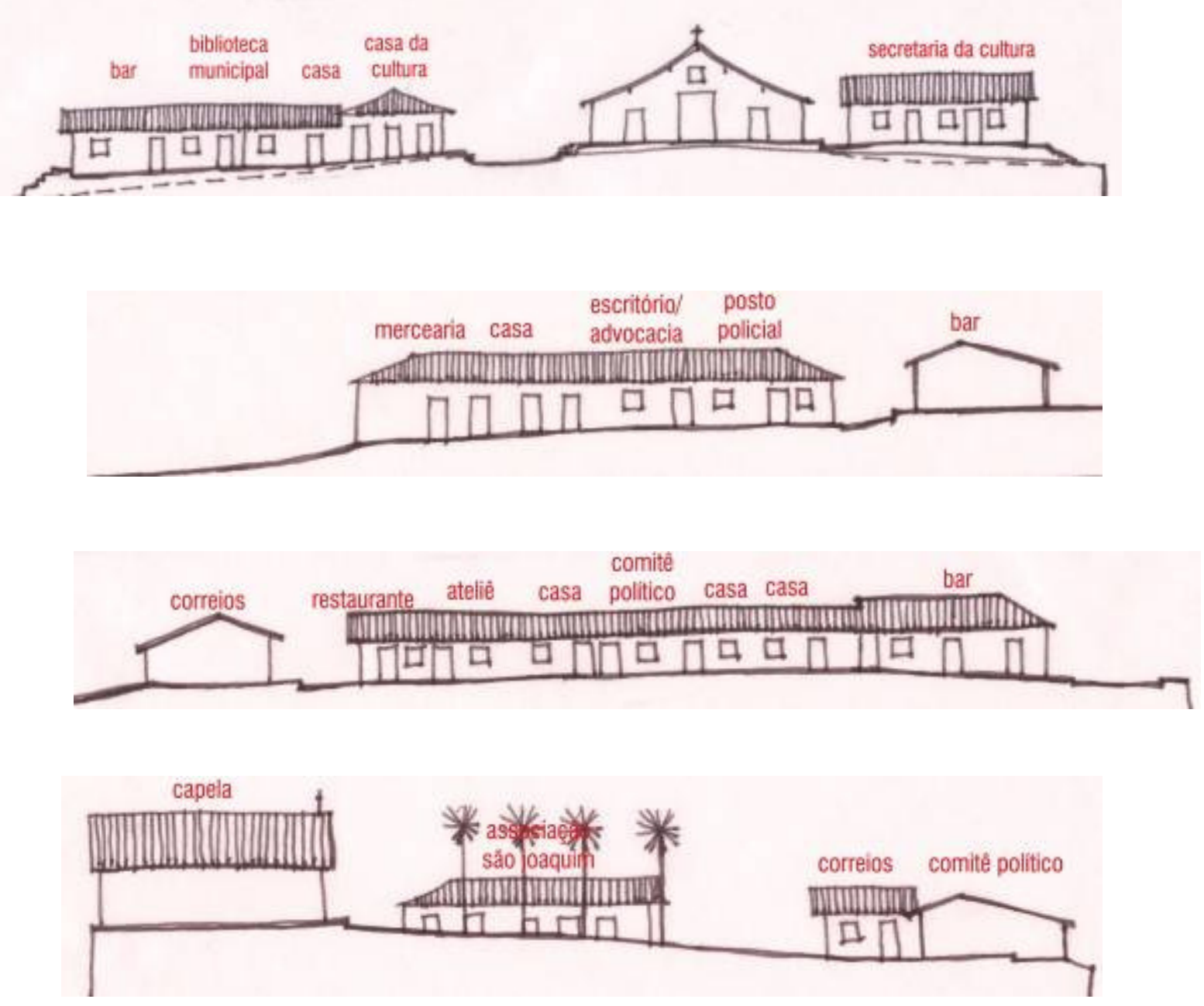

Figura 106 - Croquis - Elevações da Aldeia- uso e ocupação atual. Fonte: arquivo pessoal, 2007. 
IMAGENS DA ALDEIA DE CARAPICUÍBA HOJE

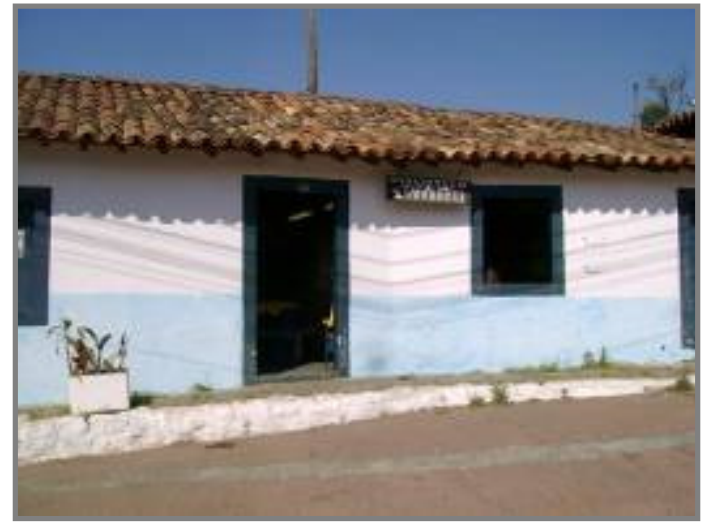

Figura 107 - Casa XIV - Biblioteca Municipal e casa XV -imóvel vazio. Fonte: Arquivo pessoal, 2007.

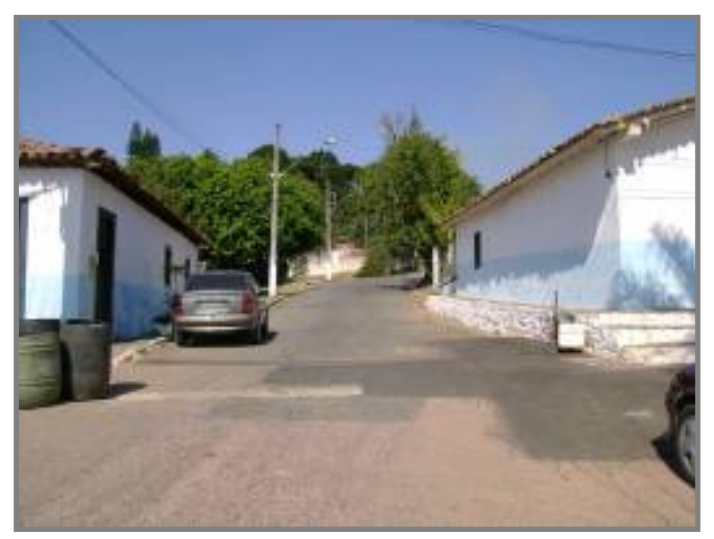

Figura 109 - Estrada da Aldeia entre a Casa da Cultura ( casa XVI) e Capela. Fonte: Arquivo pessoal, 2007.

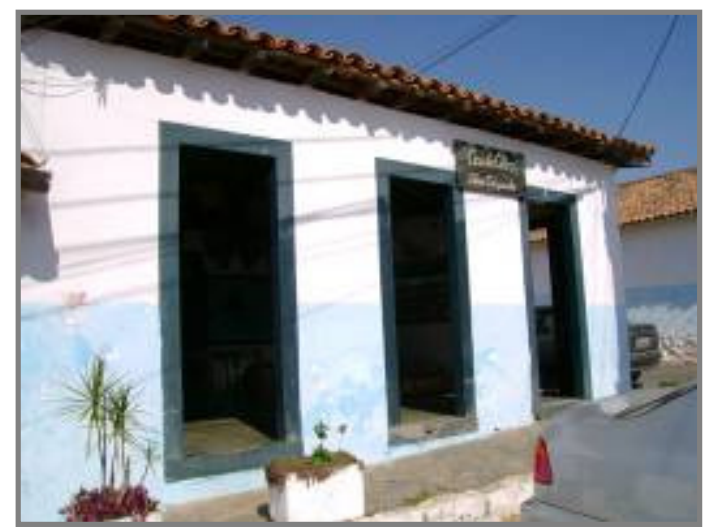

Figura 108 - Casa XVI - Casa da Cultura. Fonte: Arquivo pessoal, 2007.

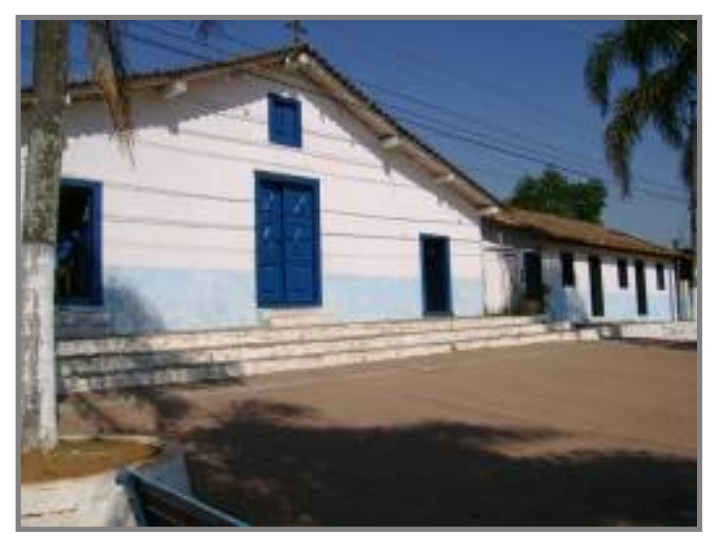

Figura 110 - Capela. Fonte: Arquivo pessoal, 2007. 


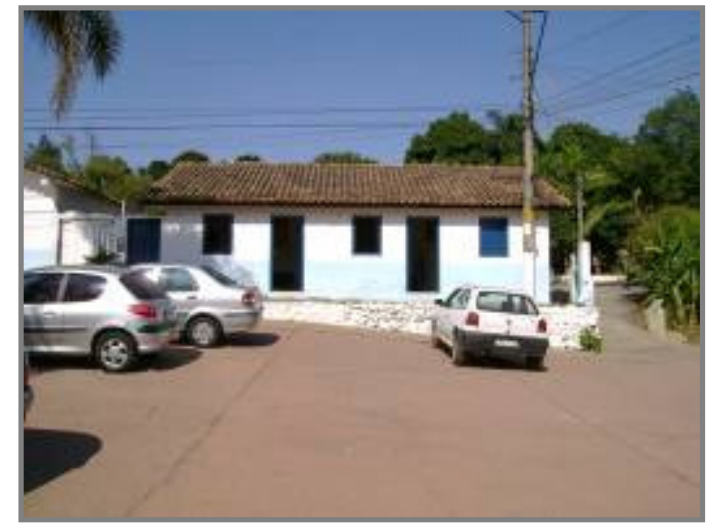

Figura 111 - casas XVII e XVIII - Secretaria da Cultura. Fonte: Arquivo pessoal, 2007.

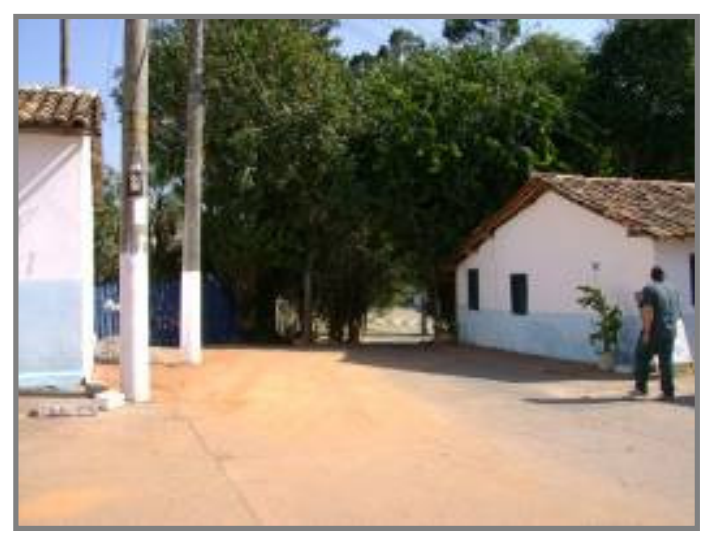

Figura 113 - Estrada dos Mineiros entre as casas XIX e I - Correios. Fonte: Arquivo pessoal, 2007.

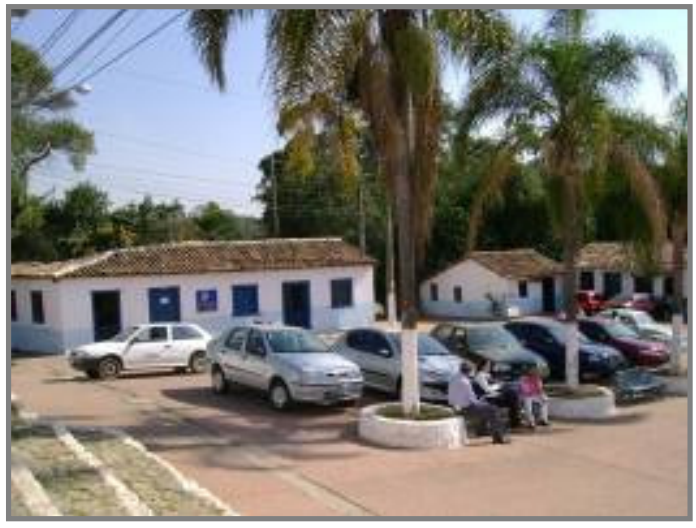

Figura 112 - Casa XIX - Associação são Joaquim. Fonte: Arquivo pessoal, 2007.

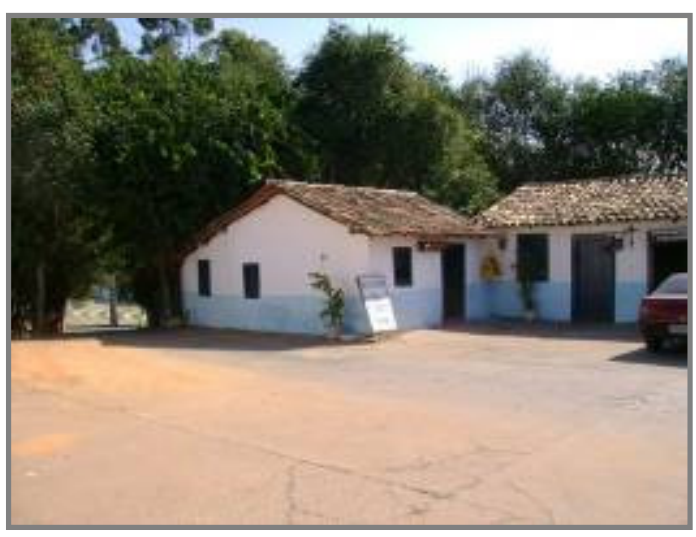

Figura 114 - Casa I - Correios e parte da casa II restaurante. Fonte: Arquivo pessoal, 2007. 


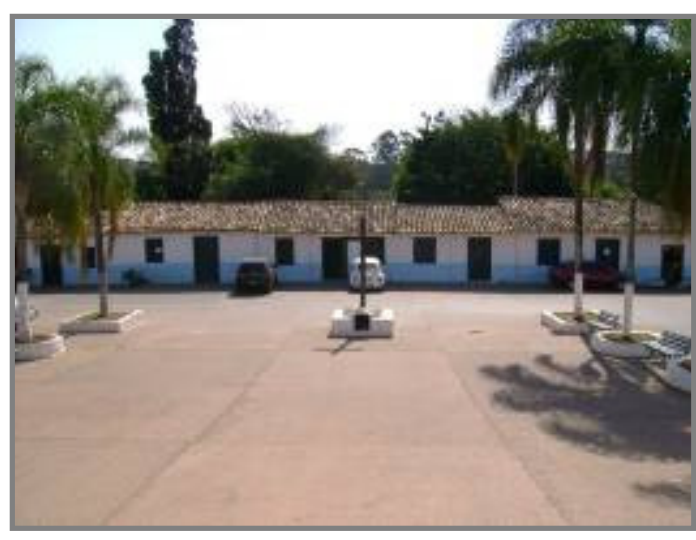

Figura 115 - Casa II a Casa VII. Fonte: Arquivo pessoal, 2007.

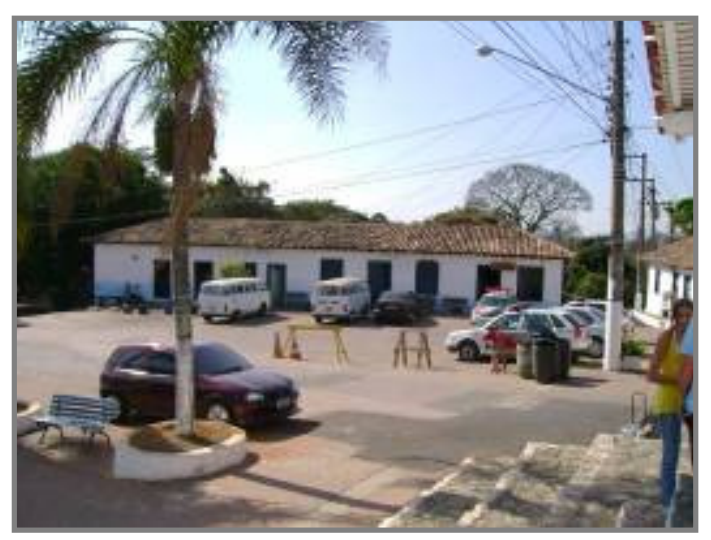

Figura 117 - Casa IX a Casa XII - Bar, imóvel vazio, escritório e posto policial. Fonte: Arquivo pessoal, 2007.

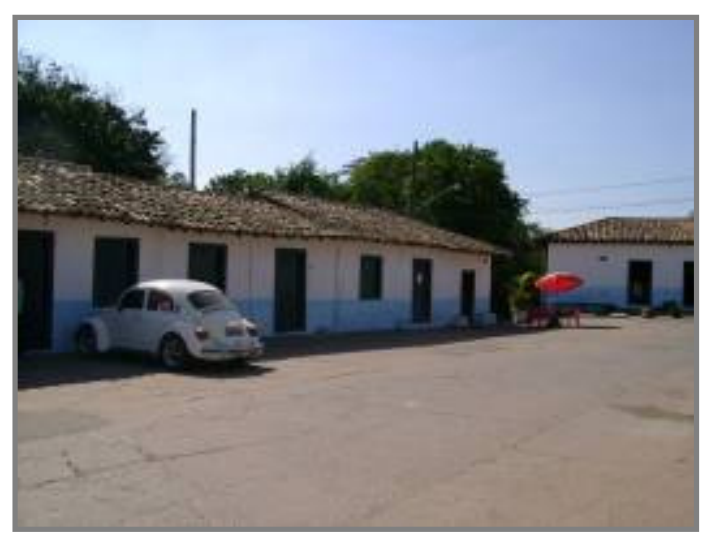

Figura 116 - Casa V a Casa VIII - imóveis vazios e bar. Fonte: Arquivo pessoal, 2007.

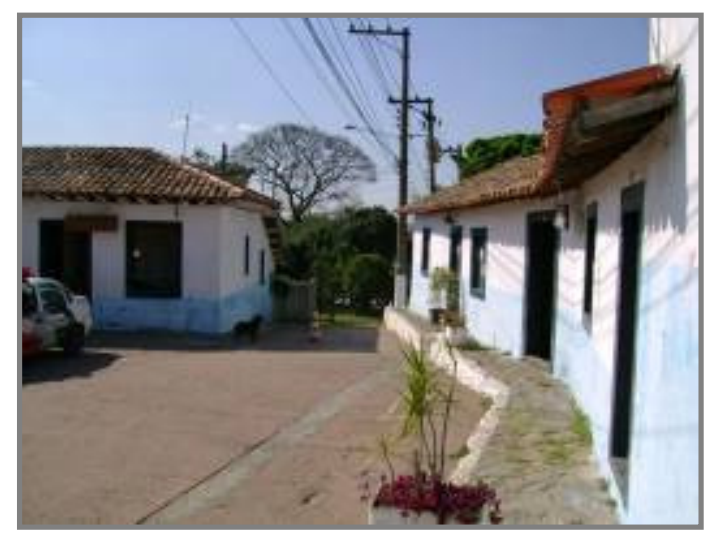

Figura 118 - Casa XII a Casa XIV- Posto policial, bar e Biblioteca Municipal. Fonte: Arquivo pessoal, 2007. 
A partir da compreensão da Aldeia de Carapicuíba Contemporânea, por meio do entendimento da paisagem, da evolução da sua ocupação, das manifestações populares tradicionais e o conhecimento dos usos e ocupação atual, pode-se compreender sua atualização e perenidade.

Percebe-se claramente, ainda, que o conjunto arquitetônico e urbanístico da Aldeia de Carapicuíba, apesar dos esforços do IPHAN, da Prefeitura Municipal e de alguns grupos da comunidade, continua sofrendo as conseqüências do caótico crescimento de urbanização de periferia, com ocupações e anexos irregulares que gera usos indevidos. A Aldeia ainda almeja efetiva valorização e padece com a indefinição de suas funções e apropriada utilização.

Como a implantação do Parque Cultural da Aldeia é recente, acredita-se que a população está em processo de apropriação do espaço. Portanto, devem-se criar novas relações entre o quadrilátero da Aldeia e o contexto urbano mais amplo, estabelecer vínculos, relações de 
interesse por meio da atuação de prestação de serviços à comunidade, fortalecendo, assim, elos afetivos e culturais. 


\section{OCA - ESPAÇO DE MANIFESTAÇÃO DA CULTURA INFANTIL}




\section{OCA - ESPAÇO DE MANIFESTAÇÃO DA CULTURA INFANTIL}

[...] é necessário aprender a "estar aqui" no planeta. Aprender a estar aqui significa: aprender a viver, a dividir, a comunicar, a comungar; é o que se aprende somente nas - e por meio de - culturas singulares. Precisamos doravante aprender a ser, viver, dividir e comunicar como humanos do planeta Terra, não mais somente pertencer a uma cultura, mas também ser terrenos. Devemo-nos dedicar não só a dominar, mas a condicionar, melhorar, compreender. (MORIN, 2007 p.76)

\subsection{0 conhecimento da atuação da OCA: história, significado e identidade}

Oca - palavra de origem tupi (oká) que faz referência à construção indígena usada como moradia de uma ou mais famílias; geralmente de formato circular, onde todos os pontos da circunferência apresentam a mesma distância do centro. Diferente da forma quadrangular, que possui ângulos, o espaço gerado é uno e democrático. Assim, a habitação indígena inspirou o nome da associação da Aldeia de Carapicuíba. 


\subsubsection{História e Identidade}

A OCA está localizada em uma região de patrimônio histórico - Aldeia Jesuítica do século XVI - e a comunidade do entorno é formada predominantemente por migrantes. Neste contexto, o projeto OCA - Uma Escola Cultural - foi criado com o intuito de valorizar a riqueza cultural da mesma, fazendo com que essa comunidade se reconheça e faça desse espaço um lugar onde possa manifestar e ver manifestada sua cultura.

Nasceu como um elemento de consciência que auxiliou o processo de compreensão do que é a Aldeia pela comunidade. Considerando que pouco aprende-se e pouco fala-se sobre 0 Brasil e sua cultura nas escolas e meios de comunicação, o projeto é um lugar para se "ouvir o Brasil" e conhecê-lo por meio da incorporação do repertório de suas Danças, seus Cantos, sua História e Lendas, suas Artes e Artesianas, seus Brinquedos e Brincadeiras, na educação de crianças e adolescentes. 
É no encontro com o seu passado que um grupo humano encontra energia para enfrentar seu presente e preparar seu futuro. A busca do futuro melhor deve ser complementar, não mais antagônica, ao reencontro com o passado. Todo ser humano, toda coletividade deve irrigar sua vida pela circulação incessante entre o passado, no qual reafirma a identidade ao restabelecer 0 elo com os ascendentes, o presente, quando afirma suas necessidades, e 0 futuro, no qual projeta aspirações e esforços. (MORIN, 2007 p.77)

Em suas diferentes faixas etárias (2 a 21 anos), a população que freqüenta a OCA traz dentro de si o distanciamento físico de sua localidade natal, e, conseqüentemente, de suas fontes culturais. Tal fato leva ao desenraizamento manifesto na sua baixa estima, dificultando a criação de vínculos e interação com o meio ambiente. Assim, a cada dia, o número de pessoas que vivem longe do lugar onde nasceram cresce assombrosamente.

Segundo Milton Santos (2007, p.60), são migrações forçadas, submetidas às forças do mercado, apoiadas no consumo e na ausência de acessibilidade de bens e serviços essenciais. Além disso, o viver nas grandes cidades dissolve e míngua as solidariedades ancestrais, extermina a cultura popular em nome da cultura de massa, alienada e dependente do consumo. 
SANTOS (2007, p.29-30) alerta que,

[...] a dependência em relação aos novos objetos limita sua vocação para obter uma individualidade e reduz a possibilidade dos encontros interpessoais diretos e enriquecedores, porque simbólicos em sua própria origem. A comunicação entre as pessoas é frequentemente intermediada por coisas. Frequentemente os movimentos de massa também se esgotam nas coisas, tendo uma lógica mais instrumental que existencial... A socialização capitalista impede movimentos globais e um pensamento global... A força da alienação vem dessa fragilidade dos indivíduos, quando apenas conseguem identificar o que os separa e não o que nos une".

É dessa maneira que 0 consumismo ${ }^{41}$ acaba diminuindo gradativamente outras sensibilidades, como a personalidade e a consciência de individualidade, sendo que esta última constitui-se como um dos alicerces da cidadania.

Diante das referidas características as atividades da OCA privilegiam o reencontro desta população com as várias linguagens expressivas de suas localidades de origem, tendo em vista a viabilização de reintegrar suas raízes, ou seja, recriar vínculos entre pais e filhos,

\footnotetext{
${ }^{41}$ Milton Santos $(2007$, p.51) afirma que esse aprisionamento do indivíduo pelas coisas que ele cria é que conduz à alienação, um "processo de fragmentação do conhecimento e, consequentemente, uma distorção da realidade humana" (apud, Navarro de Britto, 1997, p.344).
} 
alimentando a auto-estima de ambos. Além de utilizar a cultura como instrumento de transformação social.

Dentro das populações de periferia, que estão à margem do processo de desenvolvimento urbano, está a parte significativa de uma cultura ainda viva, que é utilizada dela como alimento para sobrevivência nas grandes cidades. Tais pessoas detêm hoje a riqueza da diversidade cultural brasileira que precisa ser urgentemente conhecida e reconhecida para que a nação dê o salto necessário a uma educação, sendo esta capaz de legitimar o nosso povo e nossa cultura, criando a identidade distintiva do Brasil. A ponte da educação brasileira com a cultura popular tem a mesma qualidade transformadora do elo que precisa ser estabelecido entre educação com o conceito da cultura da criança. Ambas trazem o que temos de essencial na experiência humana.

Entende-se por patrimônio cultural imaterial as práticas, representações, expressões, conhecimentos e técnicas - junto com instrumentos, objetos, artefatos e lugares que thes são associados - que as comunidades, os grupos e, em alguns casos, os indivíduos reconhecem como parte integrante de seu patrimônio cultural. Este patrimônio cultural imaterial que se transmite de geração em geração, é constantemente recriado pelas comunidades e grupos em função de seu ambiente, de sua interação com a natureza e de sua história, gerando um sentimento de identidade e continuidade, contribuindo assim para promover o respeito à diversidade cultural e à criatividade humana.

(Convenção para a salvaguarda do patrimônio cultural imaterial, Paris, 2003.) 


\subsubsection{0 início}

A pedagoga Maria Amélia Perreira ${ }^{42}$, responsável pelo Centro de Estudos Casa Redonda e moradora da região da Aldeia de Carapicuíba, desenvolvia, em meados dos anos 80, um trabalho de documentação das brincadeiras de rua. Buscava registrar o repertório gestual das brincadeiras, por meio da observação corporal, bem como dos aspectos emocionais e cognitivos, manifestadas pelas crianças ao brincar.

A partir do contato direto com a comunidade, ficou incomodada com 0 descaso das autoridades pelo patrimônio histórico da Aldeia e também com o patrimônio humano ainda vivo ali. Assim, iniciou um movimento junto com outros profissionais que tinha como objetivos a recuperação e a preservação da Aldeia de Carapicuíba.

\footnotetext{
${ }^{42}$ Ver breve apresentação da vivência da pedagoga Maria Amélia Pereira no Capítulo 1.2 “0 Brincar e a Cultura da Infância”, página 19 desta dissertação.
} 
A primeira providência tomada foi retirar de circulação os ônibus no pátio da Aldeia e assim, ter de volta uma vida comunitária no terreiro do antigo aldeamento jesuítico. Por meio de diversas iniciativas, muitas atividades foram implantadas para difundir a importância da Aldeia entre os próprios moradores locais, dada a importância histórica reconhecida daquele espaço, assim como da recuperação da cultura daquela população formada principalmente por migrantes nordestinos.

Com isso, a iniciativa pela preservação da Aldeia irradiou também 0 cuidado com a comunidade, e ,em 1996, iniciaram algumas atividades para crianças e adolescentes no pátio da Aldeia. A semente foi lançada no terreiro.

Aulas de frevo e capoeira eram dadas no meio da praça da Aldeia por um jovem ${ }^{43}$ brincante ${ }^{44}$, o Fofão, recém chegado do Recife, que tinha o salário pago por uma escola particular de São Paulo.

\footnotetext{
${ }^{43}$ Jorge Luciano da Silva: dançarino e brincante, professor de capoeira, frevo e percussão da equipe da OCA, mais conhecido como
} "Fofão". 
Nesse período, as atividades foram realizadas na praça. Com o expressivo número de crianças envolvidas, a Secretaria de Cultura do Município cedeu uma sala na Casa da Cultura, localizada no quadrilátero da Aldeia, a OCA (casa XVI) era chamada de Casa da Criança.

Em seguida, em 1999, uma pesquisadora ${ }^{45}$, Vera, bolsista da Fundação Vitae, introduziu um trabalho de Cavalo Marinho ${ }^{46}$ com crianças, desenvolvendo em grupo toda a indumentária.

A presença da música tornou-se essencial, arregimentando um professor ${ }^{47}$, Moxé, específico para isso e também uma professora ${ }^{48}$, Mary, de artes e artesanias.

\footnotetext{
44 "Brincante é o modo como os artistas populares se autodenominam. 0 artista popular nunca se nomeia 'dançarino ou ator', ele se diz 'brincante'; ao realizar um espetáculo, não diz que vai 'fazer um show', diz que vai 'brincar'. Essa visão lúdica do fazer artístico estabelece fronteiras tão distantes da nossa realidade contemporânea que se faz necessário o estudo para compreender a profundidade dessa denominação". (TEATRO BRINCANTE)

${ }^{45}$ Vera Athaíde: arquiteta de formação e professora de dança da equipe da OCA.

${ }^{46}$ Cavalo Marinho; é um folguedo popular ligado à tradição das danças dramáticas Janeiras e Reisados - trazidos pelos portugueses e incorporados pela população nordestina - que ocorre no período de 12 dias, entre a véspera de Natal e o dia de Reis. É uma das variantes do Bumba-meu-boi.

${ }^{47}$ Moxé Ribeira, músico e capoeirista.

${ }^{48}$ Maria do Carmo Lima (Mary), professora de artes, artesanias e figurinista da OCA.
} 
Depois foi cedido um pequeno espaço, um anexo ao lado da Casa da Cultura, na estrada da Aldeia, sendo reformada junto com a própria comunidade. 0 local foi derrubado posteriormente, pois estava inserido no perímetro de Zona de Preservação Histórica - ZPH. Portanto, as atividades voltaram a ser desenvolvidas no pátio da Aldeia.

Foi quando a prefeitura cedeu provisoriamente um galpão desapropriado - uma pequena fábrica abandonada -, próximo à Aldeia, para abrigar as aulas da OCA.

Com o novo espaço, o número de crianças aumentou e diversas solicitações surgiram, tais como um acompanhamento mais direcionado à linguagem, devido as deficiências da escolaridade. Tornou-se evidente a necessidade de uma educadora ${ }^{49}$, Lucilene, presente nas diversas atividades da OCA para captar as dificuldades das crianças sob o ponto de vista de linguagem. Desse modo, elaborando uma dinâmica significativa para que a referida população - de crianças, jovens e adultos - adquira e domine a linguagem oral e escrita como instrumento expressivo de sua cultura.

\footnotetext{
${ }^{49}$ Lucilene Silva, educadora musical, responsável pelo Centro de Estudo e Irradiação da Cultura Infantil da OCA, desde 2002 faz parte da equipe OCA.
} 
E, apesar de 0 galpão possuir área superior a todos os espaços anteriormente ocupados, ainda era precário. Então, o desejo de criar um espaço de qualidade para abrigar as atividades da OCA gerou um movimento de busca de uma área para erguer a sede própria; um local pensado para as crianças da Aldeia e que respondesse às questões básicas emergentes.

Em 2006, a Prefeitura Municipal de Carapicuíba formalizou a transferência para a associação de uma área em comodato dentro do Parque da Aldeia de Carapicuíba, na área do galpão, próxima ao pátio da Aldeia. Assim, foi desenvolvido um projeto arquitetônico que atendesse as demandas e os requisitos para sua inserção no âmbito histórico respectivo, bem como sua participação no grande parque popular que abriga hoje esse patrimônio.

A construção, iniciada em 2007, teve sua realização parcial e sua ocupação efetivada desde 0 inicio de 2008. 


\title{
4.2 Uma Escola Cultural e suas atividades
}

\begin{abstract}
As mudanças culturais só acontecem quando ocorre uma modificação no emocionar que assegure a conservação da nossa rede de conversações que constitui a nova cultura. Como isso acontece? Há variações segundo as distintas circunstancias históricas, mas a conservação do novo emocionar deve ocorrer por meio das crianças da comunidade. Dessa maneira, o modo como vivemos com nossas crianças é, ao mesmo tempo, a fonte e o funcionamento da mudança cultural e o mecanismo que assegura a conservação da cultura que se vive. (MATURANA 2004, p 23)
\end{abstract}

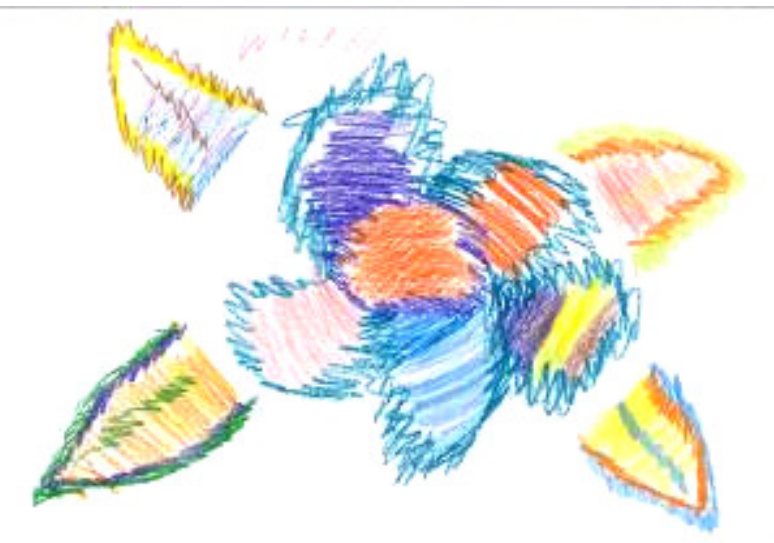

Figura 119 - Desenho Wilker, 10 anos. Fonte: Arquivo OCA, 2007.

A OCA é uma escola cultural que propõe abrigar projetos que legitimem e afirmem a história e a identidade do brasileiro. É um espaço livre que permite a criança vivenciar seus tempos, onde a infância se manifesta livremente o espaço do brincar. 
Acredita que qualquer transformação social passa pelo indivíduo. 0 fato dos jovens pertencerem a essa comunidade faz com que eles a conheçam e saibam de suas necessidades, podendo ser agentes transformadores conscientes. Certamente farão estas transformações pautadas na cultura e identidade desse povo, uma vez que eles próprios vivenciaram o processo de "re-conhecimento".

0 seu compromisso está na ação com a comunidade que a integra, contribuindo para uma melhor qualidade de vida - sendo esta compreendida como o aprimoramento da consciência que traz embutido o refinar dos sentimentos - único caminho para curar o autoritarismo, 0 egoísmo, a ganância e a violência.

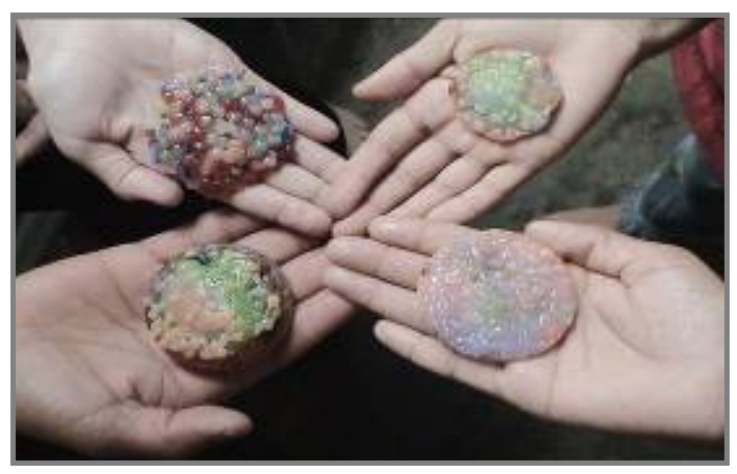

Figura 120 - Brincadeira da vela. Fonte: Arquivo OCA, 2004. 
É uma Escola Cultural que abriga:

I.Centro de Referência da Cultura Brasileira: Por meio da dança, da música, das artes plásticas e das brincadeiras, pratica as atividades expressivas da cultura brasileira. Apresenta como objetivo desenvolver documentação e divulgação da cultura brasileira, por meio de encontros ao longo do ano, aproveitando o ciclo de festas, que desenvolvem as linguagens expressivas interligando 0 gestual das danças, os cantos e instrumentos musicais, adereços, ornamentos e vestimentas dos respectivos "Folguedos", sejam 0 indígena, 0 africano e o português. Esses repertórios festivos representam e confirmam a formação mestiça do brasileiro à comunidade da Aldeia.

Preza a manutençao e intercâmbio com os mestres populares e seus brincantes.

II.Centro de Estudos e Irradiação da Cultura Infantil:

Oferecendo como resultado um acervo constituído por instrumento para monitores e educadores no desenvolvimento de suas atividades com as crianças, bem como a formação 
de educadores, exercita a Música da Cultura Infantil, de pesquisa e documentação do repertório de brinquedos e brincadeiras da comunidade local.

III.Centro de Formação de Educadores Brincantes e Alfabetização:

Objetiva a formação e encaminhamento profissional de jovens capacitados em música, dança, artes e artesanias, brincadeiras, Lingua Portuguesa(leitura e escrita) e informática; Acompanhamento escolar de crianças e adolescentes de 7 a 14 anos, que visa 0 fortalecimento da escola pública e preparação desses alunos para a Formação como Educador Brincante; destacando, também, a preocupação com a alfabetização de adultos da comunidade. 


\subsubsection{As Brincadeiras}

Em 2003, por meio da implantação do Centro de Estudos e Irradiação da Cultura Infantil, inaugurou-se um espaço só para brincar. Sob a coordenação da educadora Lucilene Silva, as brincadeiras foram implantadas na OCA incorporadas às atividades já desenvolvidas (dança, música, artes e artesanias e capoeira).

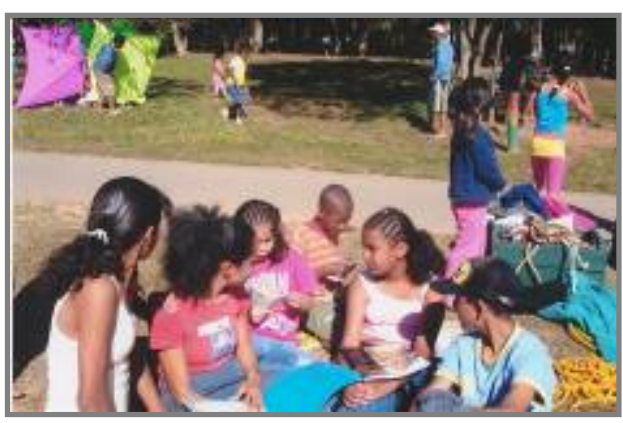

Figura 121 - Brincadeiras no Parque. Fonte: Arquivo OCA, 2004.

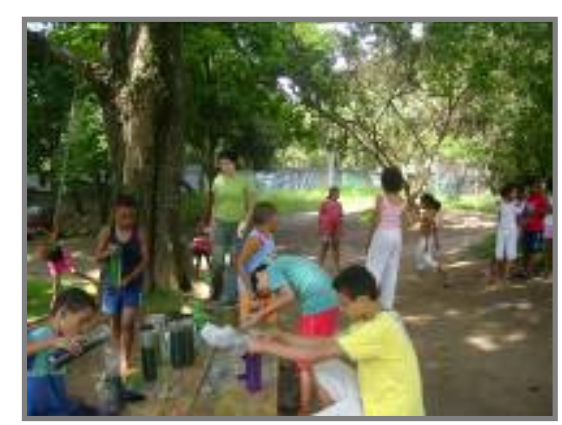

Figura 122 - Brincadeiras na área externa do Galpão. Fonte: Arquivo pessoal, 2007.

São reservados dos dias por semana só para brincar, é claro que a brincadeira está presente no dia-a-dia, durante as outras atividades, mas esses dois dias a atenção está voltada somente para o brincar. 
As crianças e adolescentes trazem as brincadeiras que fazem parte do seu cotidiano, brincadas na rua e na escola ou que aprenderam com os pais e amigos.

A partir disso, acontece uma pesquisa e documentação do repertório de brinquedos e brincadeiras, cantigas e histórias do universo infantil da comunidade da Aldeia de Carapicuíba. Com esse material cria-se um acervo da Cultura da Criança, disponível para educadores e pesquisadores interessados.
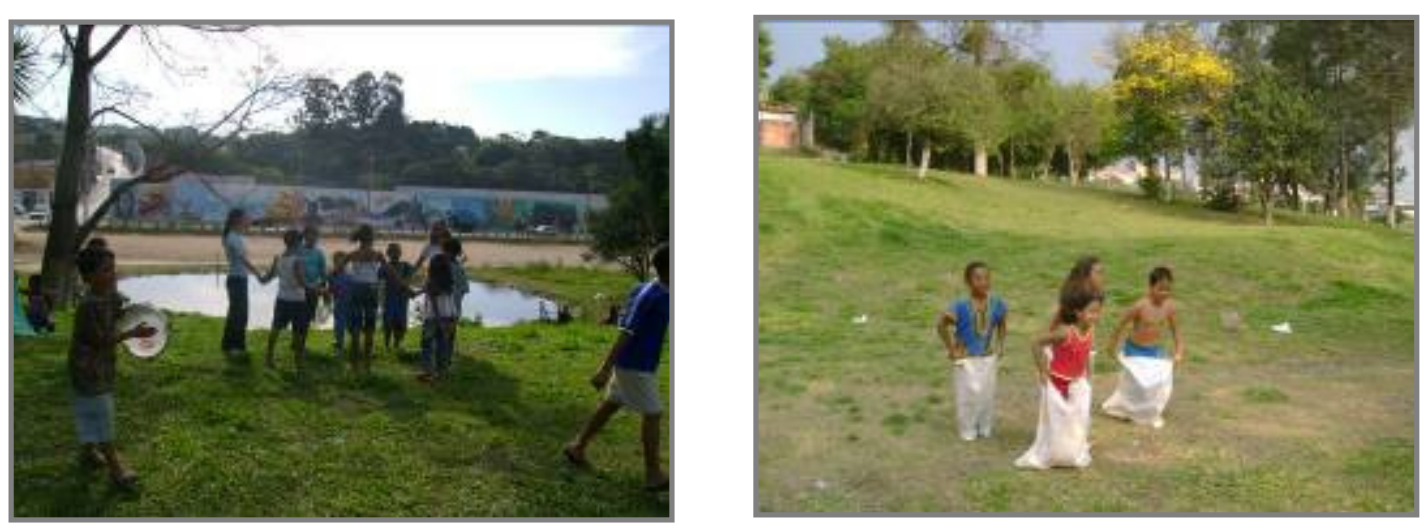

Figura 123 e 124 - Brincadeiras no Parque da Aldeia. Fonte: Arquivo pessoal, 2007.

0 projeto de brincadeiras foi estendido, inicialmente, para o recreio de uma escola pública da região, escola Esmeralda Becker, atendendo quase 800 crianças da $1^{\mathrm{a}} \mathrm{a} 7^{\mathrm{a}}$ série. A abertura 
para o brincar dentro da escola formal foi tão significativa, com grande envolvimento dos professores e alunos, que a brincadeira foi levada para as salas de aula; cada classe possui um horário na semana reservado para brincar. Além disso, os professores incorporaram algumas brincadeiras no processo de alfabetização. Tudo isso foi possibilitado pelo acolhimento da direção da escola, na época Maria Helena, professora de educação artística que sempre valorizou novas formas de expressão dentro da educação.

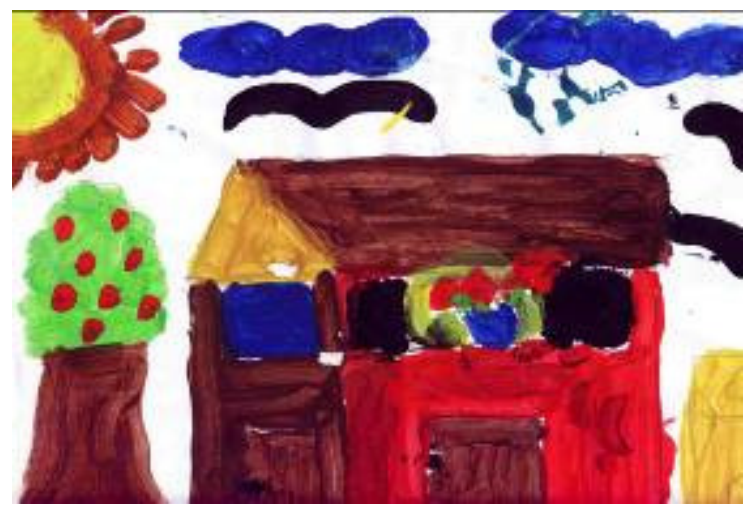

Figura 125 - Pintura com guache - Tainá, 8 anos . Fonte: Arquivo OCA, 2004.

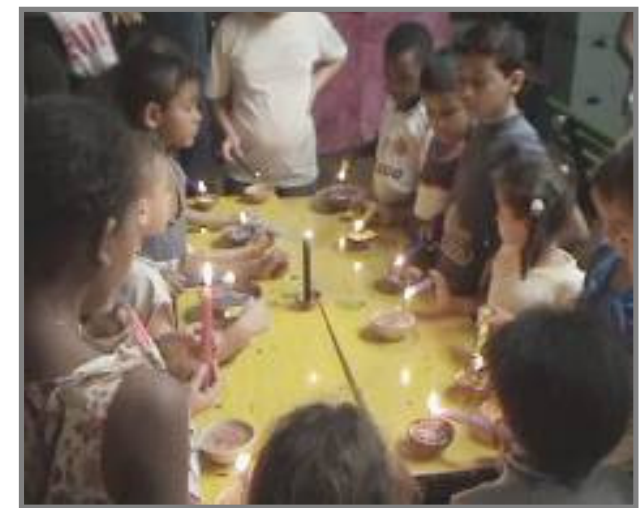

Figura 126 - Brincadeiras com velas. Fonte: Arquivo OCA, 2004. 


\subsubsection{Os Folguedos Populares}

Os folguedos populares foram chamados por Mario de Andrade de danças dramáticas. É sabido que os jesuítas utilizaram as danças e costumes do povo, sob a forma de teatro religioso, para catequizar os índios, os negros e os próprios portugueses colonizadores. Utilizaram sabiamente a linguagem dos grupos existentes para convertê-los. Assim, difundiram os bailados por todo o território brasileiro. Para Mario de Andrade (2002, p.31) a dança dramática

\footnotetext{
[...] nasce como imposição de grupos dominantes que, na celebração, ensinam por meio do mimetismo dramático a vida imperante dos espíritos, dos deuses. Assim, não é a profanidade do heroísmo, da coragem, dos feitos históricos, tradições e costumes raciais que provocou a fundação das nossas danças dramáticas. Todas são de fundo religioso. Ou melhor, dizendo: 0 tema, o assunto de cada bailado é conjuntamente profano e religioso, nisso de representar ao mesmo tempo um fator prático, imediatamente condicionado a uma transfiguração religiosa.
}

Possuem como tema central a conversão e a ressurreição, sendo que a conversão era considerada mais elevada, portanto, era aplicada a grupos mais restritos, como irmandades de negros: a congada, por exemplo. Já a ressurreição era considerada uma temática mais 
fácil de ser assimilada, era mais popular e o bumba-meu-boi é um dos representantes desse grupo.

Normalmente são realizados em datas mais ou menos fixas e em determinadas festas. Segundo Araújo (2007, p.95), alguns folguedos podem provocar a "catarse coletiva, o povo vibra quando passa um cortejo de maracatu ou aplaude e grita numa tourada; procedendo-se uma descarga que alivia os impulsos. Exercem uma grande função catártica que os agrupamentos humanos necessitam".

Alguns exemplos de folguedos: cavalhada, carreira de cavalo, rodeio, tourada, vaquejada, carreira de bois, maracatu, afoxé, briga de galos, briga de canários da terra, capoeira, dança do bate-coxa, entrevero de facão, vivório, mamulengo e pau-de-sebo.

"Os folguedos populares e tradicionais serviam para quando o povo, concentrados nas grandes festas religiosas ou não tivessem, sob a forma de recreação, uma lição objetiva do bem vencendo o mal. Era o próprio divertimento contribuindo para a formação religiosa do povo". (ARAÚJ0, 2007, p.95) 
Segundo Mario de Andrade (2002, p.59), os folguedos se dividem em duas partes bem diferentes entre si: 0 cortej $0^{50}$, que é a locomoção dos brincantes pelas ruas sob o som dos instrumentos e cantigas e a "Embaixada", que é a representação dramática, propriamente dita, que necessita de uma área fixa: podendo ser um pátio, uma sala, um espaço em frente à igreja ou casa.

Em seu estudo sobre o folclore e grupos infantis, o sociólogo Florestan Fernandes (2004, p.459-460) relaciona a tradição aos grupos infantis. Coloca os folguedos como sendo 0 resultado da interação social dos grupos infantis, ou seja, o motivo pela qual eles se formam. Situação oposta no passado e para os adultos, pois se pode dizer que os folguedos eram o produto da vida social.

\footnotetext{
${ }^{50}$ Para Mário de Andrade, o cortejo é um elemento comum, porém importantíssimo nas danças dramáticas brasileiras. "... cortejo que perambula pelas ruas, cantando e dançandinho, em busca do local onde vai dançar a parte propriamente dramática do brinquedo. Esse cortejo, quer pela sua organização quer pelas danças e cantorias que são exclusivas dele, já constitui um elemento especificamente espetacular" (ANDRADE, 2002, p.37).
} 
As crianças brincam os mais variados folguedos inspirados no fazer popular, nunca referenciam a nomes ou mestres e dizem normalmente que aprenderam na rua. Desta forma, a criança inicia livremente seu contato com o meio social.

Então, "pode-se aceitar que esses grupos se formam em função dos fatos folclóricos, isto é, de traços que passam de geração a geração, indefinidamente, e que são partes da cultura tradicional da sociedade considerada" (2004, p.459). 


\section{Os folguedos na OCA}

Os mestres, na cultura popular, são considerados patrimônios que armazenam a sabedoria da história e dos ofícios tradicionais, por isso, os folguedos na OCA buscam inspiração na figura dos mestres, vão "beber na fonte" para recuperar o sentido daquela brincadeira e, então, atualizá-la no contexto da comunidade da Aldeia de Carapicuíba.

[...] aquele que sabe, realiza e toca inicialmente 0 destino do fazer, que é também 0 de viver sua criação. Certamente, o mestre encontra em seu trabalho, de linhagem ancestral de outros mestres, o toque sensível e mágico para construir com alma de arte sua história, marcando seu lugar e suas experiências pessoais.

0 dom de comover the pertence, pois seu toque esbarra na emoção do outro. Ao se comunicar, ele traz tudo o que viu, descobriu, inventou e a que deu continuidade, cumprindo seu destino de interlocutor e intérprete do mundo. (LODY, 2005, p.11) 
Os folguedos

\begin{abstract}
Brincadeira é termo recorrente no amplo e diverso imaginário que integra expressões populares, desde o brinquedo, objeto da instituição infantil do brincar, reproduzindo temas e cenas da vida social, dos personagens da casa, da família, tentando traduzir rituais do cotidiano cujos papéis hierarquizados são ludicamente reinventados no ato imemorial de brincar. 0 espaço e o conceito de brincadeira, contudo, ampliam-se para outros divertimentos e situações de um rico e variado campo de formas tradicionais e populares. (LODY, 2005, p.32)
\end{abstract}

Frevo

(ciclo carnavalesco)

Grande alucinação do carnaval Pernambucano, originou-se da capoeira como uma dança da multidão, de caráter primitivo, semi-bárbaro, com ritmo contagiante, acompanhada por música frenética e excitante, em que o povo se entrega "de corpo e alma" e fica a ferver; dando origem ao nome (frevura, frever). 
Apesar disso, a coreografia é dançada individualmente, porém contagia a todos, como em uma corrente eletrizante (CASCUD0, 2002, p.251). De natureza improvisatória, percorre as ruas e também os salões (como marcha).

A coreografia também é conhecida como passo; 0 dançarino pode executar variações e imprimir sua personalidade. São verdadeiras acrobacias, facilitadas pelo uso de sombrinhas coloridas, que também definem o passista. Francisco Nascimento Filho, mais conhecido como Nascimento do Passo, catalogou 48 passos, entre eles: tesoura, saca-rolha, canguru, pisando e brasa, etc.

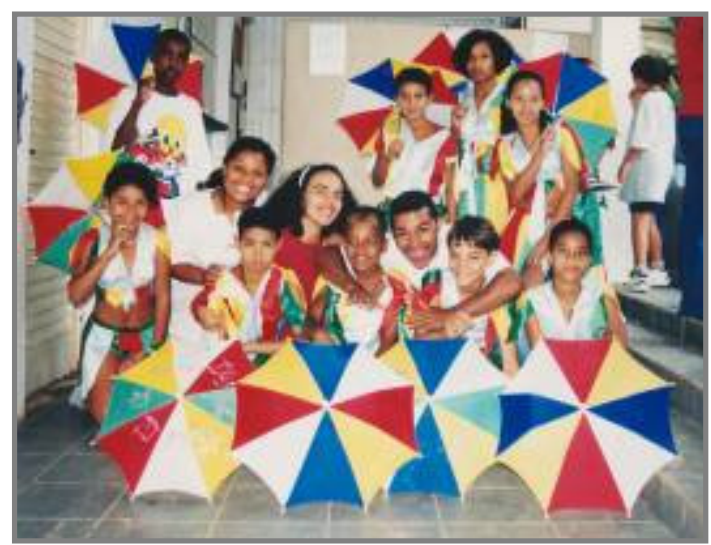

Figura 127 - Grupo Folclórico Meninos e Meninas da Aldeia após apresentação. Fonte: Arquivo OCA, 2004.

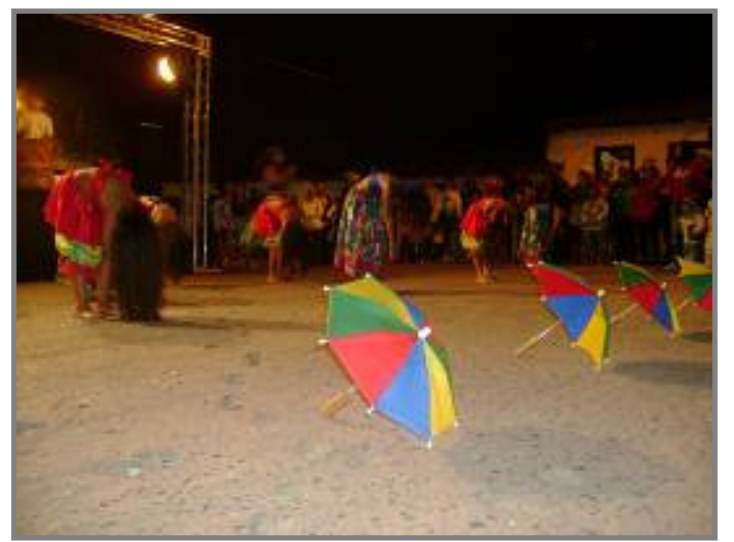

Figura 128 - Apresentação das crianças no terreiro da Aldeia, na semana do folclore. Fonte: Arquivo pessoal, 2008. 
Maracatu

(ciclo carnavalesco)

Originário de Pernambuco, o maracatu é um cortejo real que percorre as ruas dançando e cantando ao som de uma orquestra de percussão, sem coreografia específica. Também conhecido com nação, (sinônimo popular de grande grupo homogêneo), é descendente dos antigos festejos do século XVII de coroação de reis negros.

Era manifestação sagrada que passou para o Carnaval. 0 cortejo abre com o Rei e a Rainha, mais o escravo que leva o guarda-sol, o Porta-Estandarte, Príncipes, Damas, Embaixadores. Depois, seguem a Dama-de-Paço, que leva junto de si a Calunga (boneca preta de madeira), as Baianas (evocam a dança dos Xangôs), e os Caboclos, que representam os indígenas (com arco e flecha). Por fim, os batuqueiros com os instrumentos musicais. A música é cantada em diálogo pela Rainha e Baianas.

Um dos momentos mais esperados do cortejo é a dança da Calunga, onde a boneca, que representa os ancestrais masculinos ou femininos do grupo, é entregue, pela Dama-do- 
Paço, à Rainha, seguindo, depois para as Baianas, que dançam com elas por um período de tempo.

0 maracatu possui variações, dentre as quais estão, o Maracatu de Baque Solto e 0 Maracatu de Baque Virado.
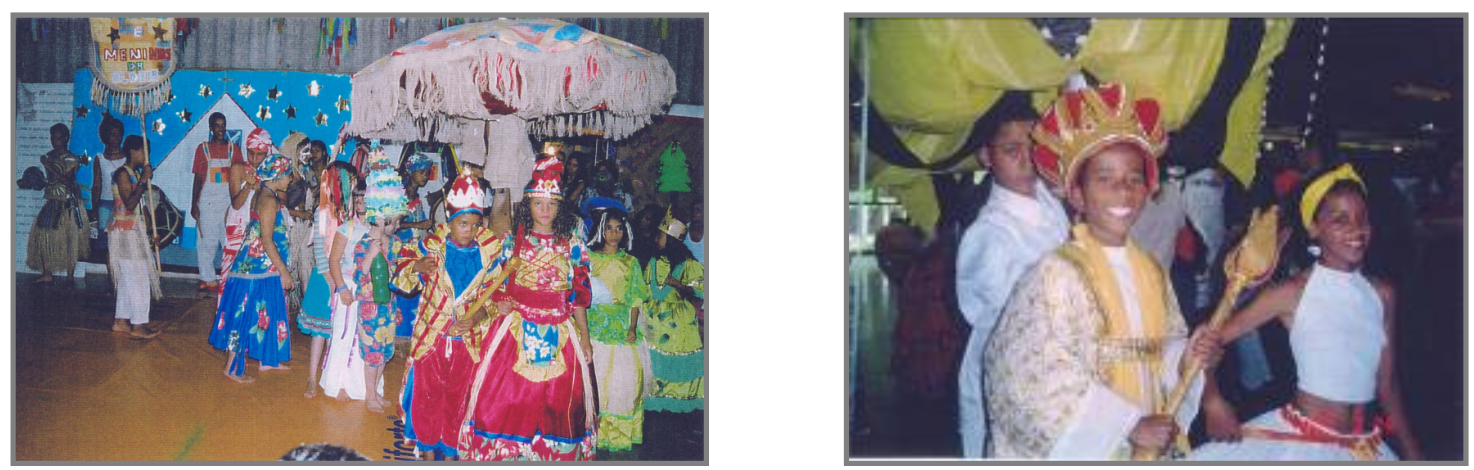

Figura 129 e 130 - Apresentação de Maracatu. Fonte: Arquivo OCA, 2004.

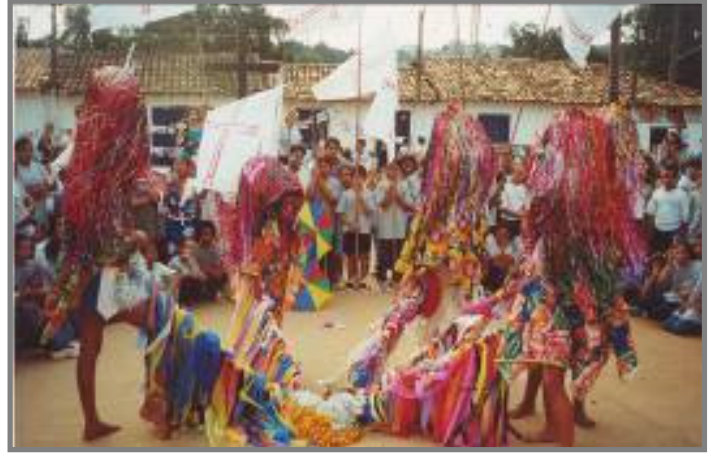

Figura 131 - Grupo Folclórico Meninos e Meninas da Aldeia. Fonte: Arquivo OCA, 2004.

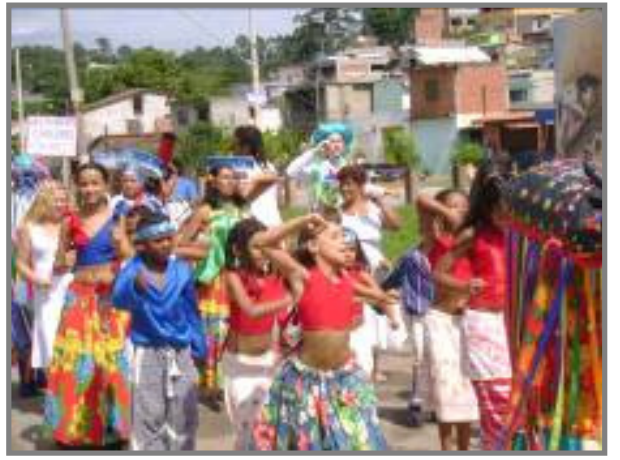

Figura 132 - Cortejo de Mracatu. Fonte: Arquivo pessoal, 2008. 
Ciranda

(ciclo junino)

0 ritual da roda é uma manifestação tradicional que permanece desde a pré-história. Segundo a tradição, 0 ato de se voltar para o centro de um círculo, em uma cadência de passos, cantando e dançando, é a forma de comunicação com os deuses.

Pode ser de mãos ou braços dados, cantando versos, ou respostas ao mestre que fica no centro ou ao lado. A temática é livre, mas normalmente o cotidiano está presente.

No Brasil as cirandas foram difundidas pelos portugueses no norte de Pernambuco; e apesar de em Portugal serem dançadas por adultos, aqui as crianças se apropriaram facilmente nas suas brincadeiras. 
Coco

(ciclo junino)

Dança popular do Nordeste com grande influência africana. Apresenta variações nas execuções entre um estado e outro. É canto-dança, sendo que o refrão responde aos versos do tirador de coco ou coqueiro (CASCUD0, 2002, p.147).

Rosane Almeida, em sua pesquisa sobre danças brasileiras, mostra que há duas versões sobre sua origem: a que originou nos quilombos - a partir do som que os cocos faziam ao serem quebrados, os negros eram "convidados" a dançar - e, com o tempo, o ruído natural foi substituído pelas palmas com as mãos encovadas, dançando aos pares em uma roda.

A outra versão se passa nas comunidades rurais do sertão nordestino, durante a execução das casas de pau-a-pique, sob 0 sistema de mutirão. A última fase da construção era 0 nivelamento do piso de barro, realizado através da dança de sapateado que assentava 0 chão, em um clima de festa oferecida pelo dono como agradecimento. 
Hoje é dançado sem que haja uma ocasião especial: forma-se uma roda de casais, sob o som de pandeiros, bombos, tamborins, zabumbas, entre outros. As melodias são improvisadas pelos tiradores de coco e os versos são repetidos por todos os integrantes. Há diversas variações do coco, entre elas, Coco de Roda, Coco de Visita, Coco Solto, Coco de Parelhas, Coco de Parelhas Ligadas. 
Cavalo-marinho

(ciclo natalino)

Como o Cavalo-marinho é uma variação pernambucana do Bumba-meu-boi, sendo pertinente uma breve apresentação desse folguedo.

0 Bumba-meu-boi é uma manifestação popular ligada às festividades Janeiras e Reisados, que ocorrem entre a véspera do Natal e o dia de Reis, ao longo de 12 dias. Foram trazidas pelos portugueses e incorporadas facilmente pelo nordestino. Portanto, o folguedo também possui influência dos indígenas e dos negros.

0 drama é composto por figuras dos animais tradicionais do presépio, como 0 boi $^{51}$ e a burrinha.

0 Cavalo-marinho é caracterizado por uma variedade de movimentos coreografados e improvisados, dispostos em uma roda formada espontaneamente pelo público. Acompanhado de poesias (loas), cantos (toadas) e música que são executados pelo Banco -

\footnotetext{
${ }^{51} \mathrm{Em}$ nota, Mario de Andrade afirma que a figura do boi tem elevado valor simbólico, hoje o boi não representa 0 animal, a "precisão da carne alimentar", e sim a "representação coletiva, a necessidade do alimento (qualquer), as dificuldades e lutas para encontrar 0 alimento, bem como práticas da vida familiar e coletiva" (2002, p. 71).
} 
grupo de músicos que tocam vários instrumentos (rabeca, pandeiro, ganzá, reco-reco e mineiro) sentados em um banco. Além dos sons dos instrumentos, há os personagens Mateus e Bastião que usam duas bexigas de boi como percussão no próprio corpo.

Outras figuras compõem o folguedo: o Capitão Marinho (central), Soldado da Guarita, Empata o Samba, Mané do Baile, os Galantes, as Damas, as Pastorinhas, Arlequim, Mestre Ambrósio, Matuto da Gama, Selador e Seu Campelo, Vila Nova, Seu Domingos, a Véia do Bambu e, por fim, o Vaqueiro e seu filho.

A brincadeira dura à noite toda e é feita entre julho e janeiro, sendo mais expressiva nos dias de Natal e de Reis. Tem como enredo, tal como 0 auto-do-boi, a história de personagens fantásticos e reais presentes na vida imaginária e cotidiana da comunidade onde é representado. 


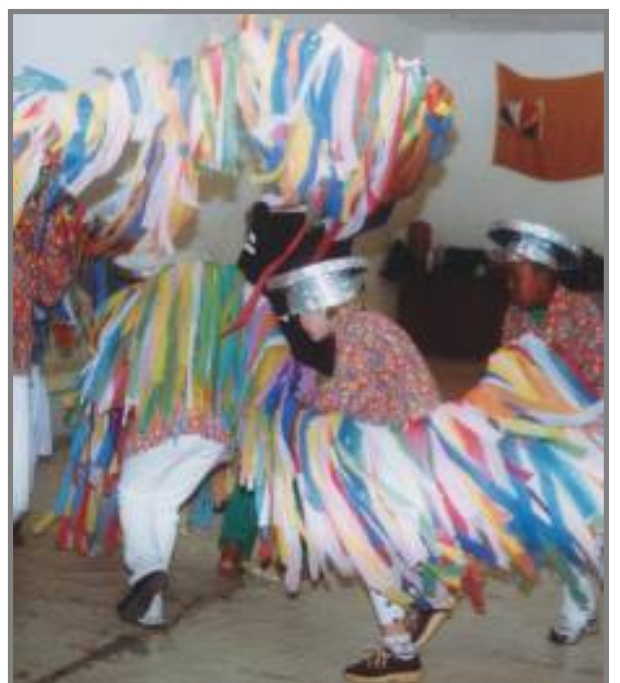

Figura 133 - Dança dos arcos, na Casa da Criança. Fonte: Arquivo OCA, 1999.

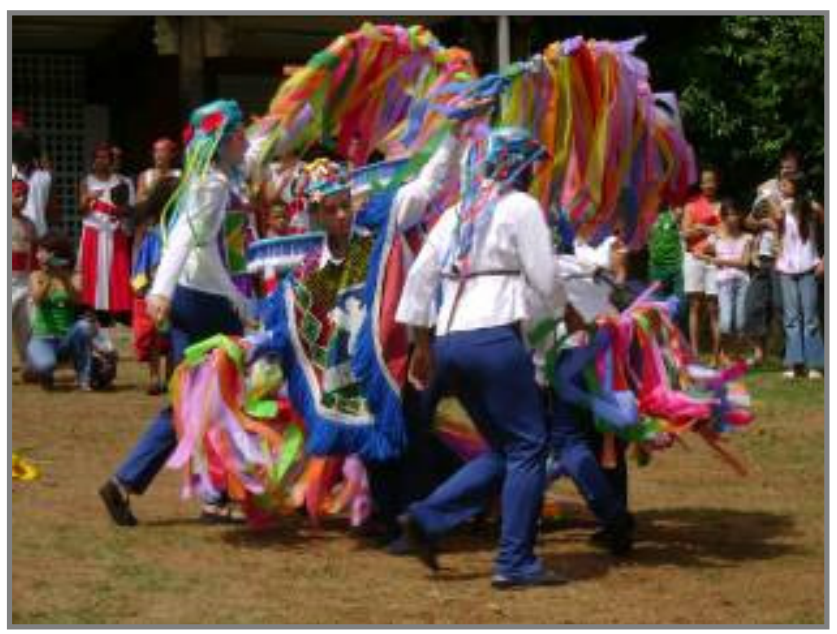

Figura 134 - Dança dos arcos, na inauguração do novo espaco. Fonte: Arauivo pessoal. 2008.
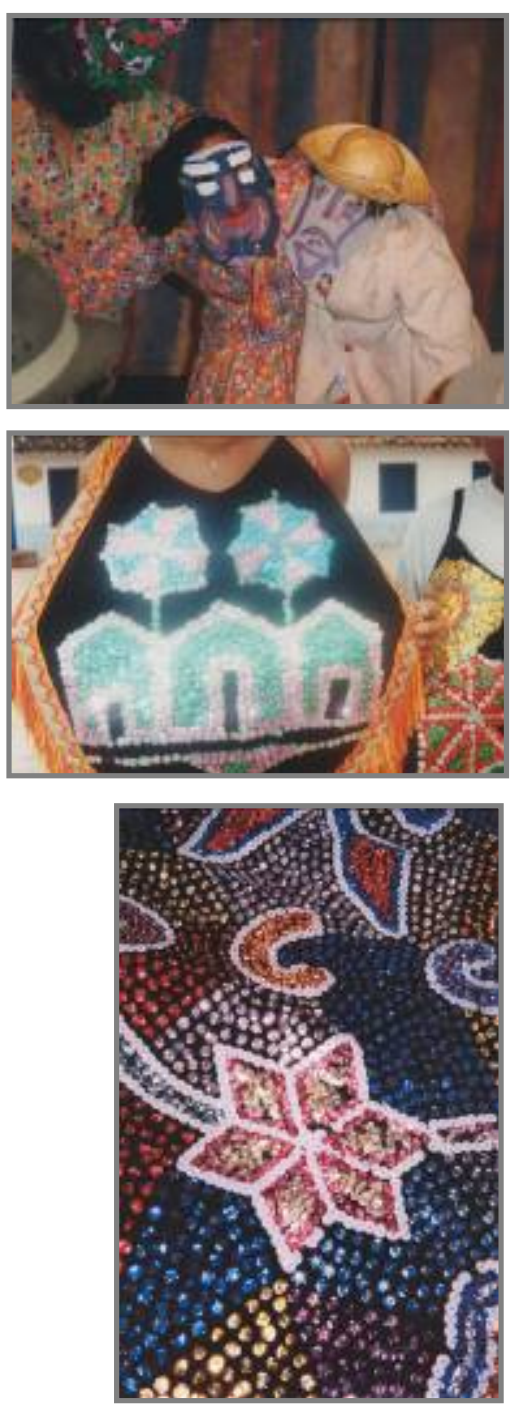

Figuras 135, 136 e 137 - Cavalomarinho, na Casa da Criança. Fonte: Arquivo OCA, 1999. 


\subsection{0 espaço da criança na OCA}

0 espaço da criança na OCA

Como já foi explicitado, ao longo da existência da OCA, verifica-se a ocupação de sucessivos espaços: o pátio da Aldeia, uma pequena sala na Casa da Cultura (edificação no quadrilátero histórico) antes chamada de Casa da Criança. Em seguida, uma edificação ao lado da Casa da Cultura no acesso ao terreiro da Aldeia, e um galpão de uma antiga fábrica desapropriado pela prefeitura. Mais recentemente, a ocupação do espaço projetado e construído parcialmente numa área em comodato, próxima à Aldeia e dentro do Parque Cultural da Aldeia de Carapicuíba.

Assim, com a reflexão do último espaço ocupado, de sua realização parcial e o entendimento de suas proposições iniciais e da realidade efetiva de sua ocupação, busca-se a compreensão da relação espaço, espaço comunitário e desenvolvimento da criança. Analisa 
em conjunto a evolução e crescimento das atividades desenvolvidas na entidade. Procura ressaltar seus significados maiores e permanentes nessa ocupação de vários espaços, além de traçar as perspectivas do desenvolvimento futuro. 


\subsubsection{Os espaços ocupados}

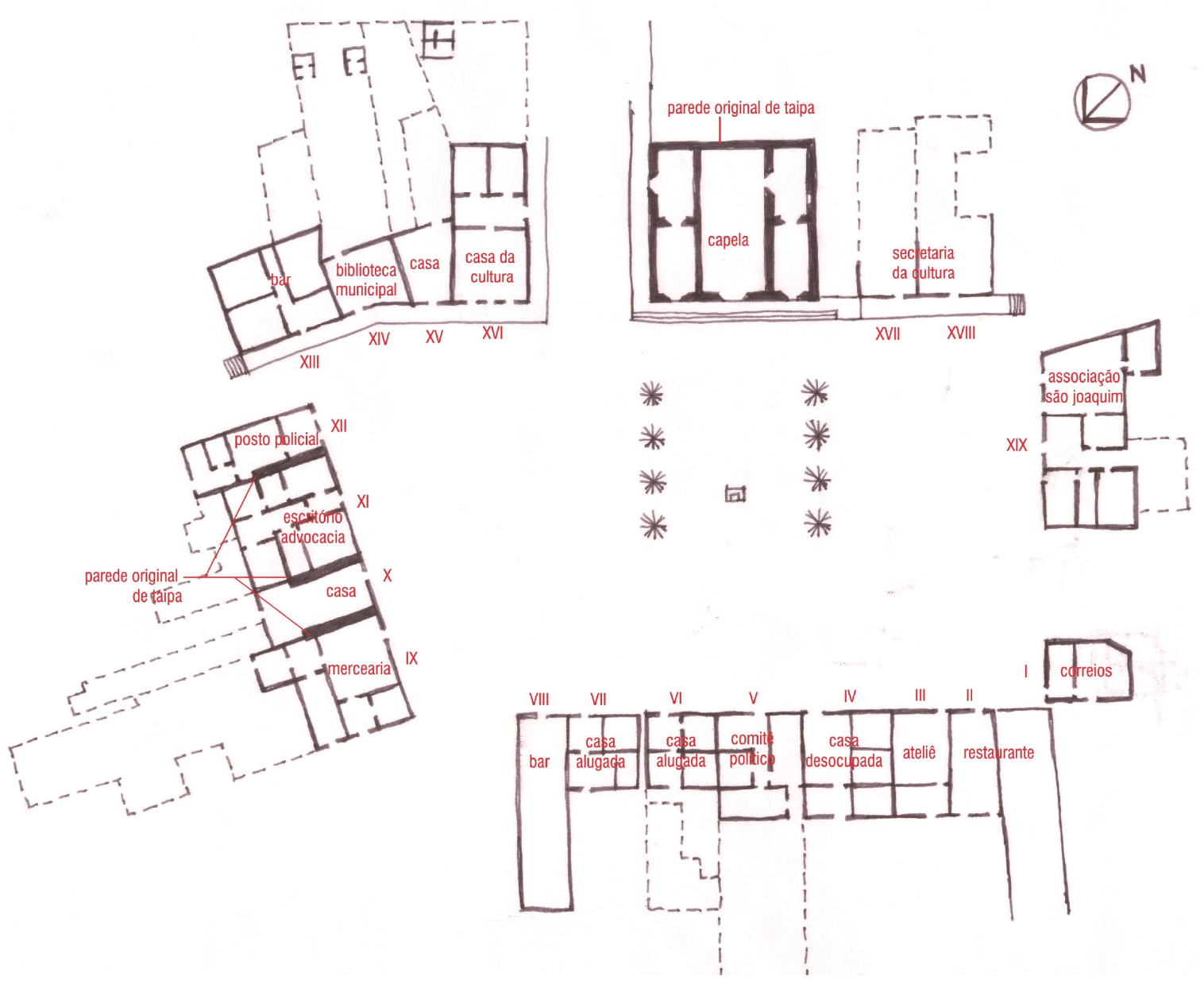

Figura 138 - Implantação da Aldeia de Carapicuíba com uso e ocupação 
1996 - 0 Terreiro da Aldeia

No início Fofão chamou a atenção das crianças por meio da capoeira, que já era uma atividade conhecida. 0 primeiro dia de atividade foi na sala de aula de uma escola pública da região - Escola Esmeralda Becker - que teve como objetivo divulgar o início da ação efetiva da OCA. Foi um sucesso, porém, o espaço físico tradicional das salas não favoreceu 0 desenvolvimento natural que a capoeira necessita e, assim, acabam ocupando o terreiro da Aldeia.

Em seguida foi iniciado um trabalho na área de dança, sendo o frevo a atração principal. Em paralelo, surgem outras oficinas: de figurinos, de artes e artesanias 


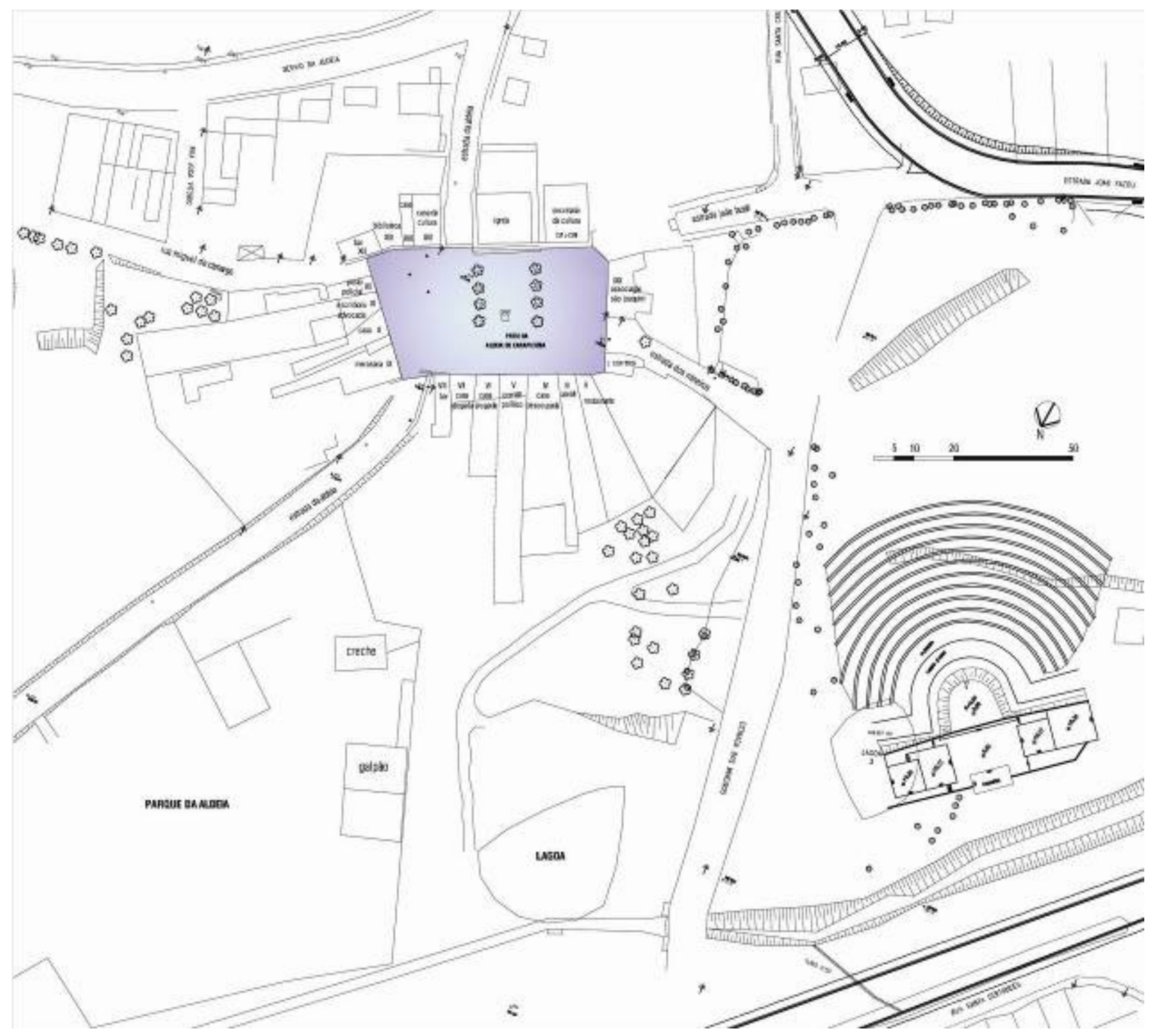

Fiqura 139 - Em 1996 a OCA se apropriava do pátio da Aldeia. Fonte: Acervo OCA e arquivo pessoal. 


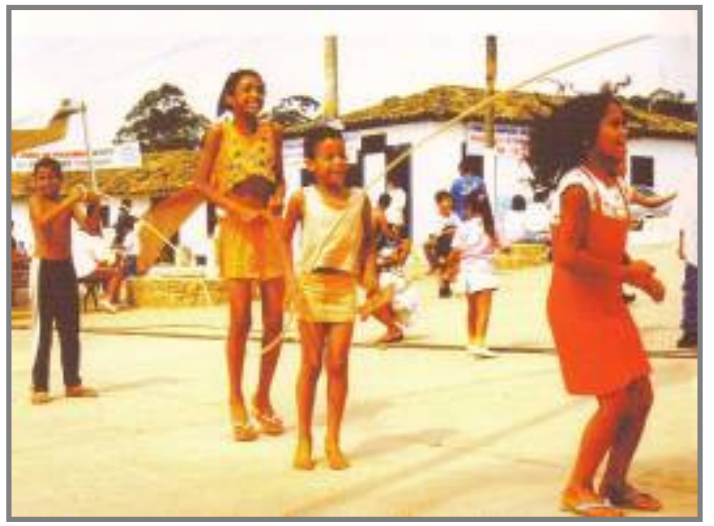

Figura 140 - As brincadeiras eram vivenciadas no terreiro, como se fossem o quintal das crianças. Fonte: acervo da OCA, 1996.
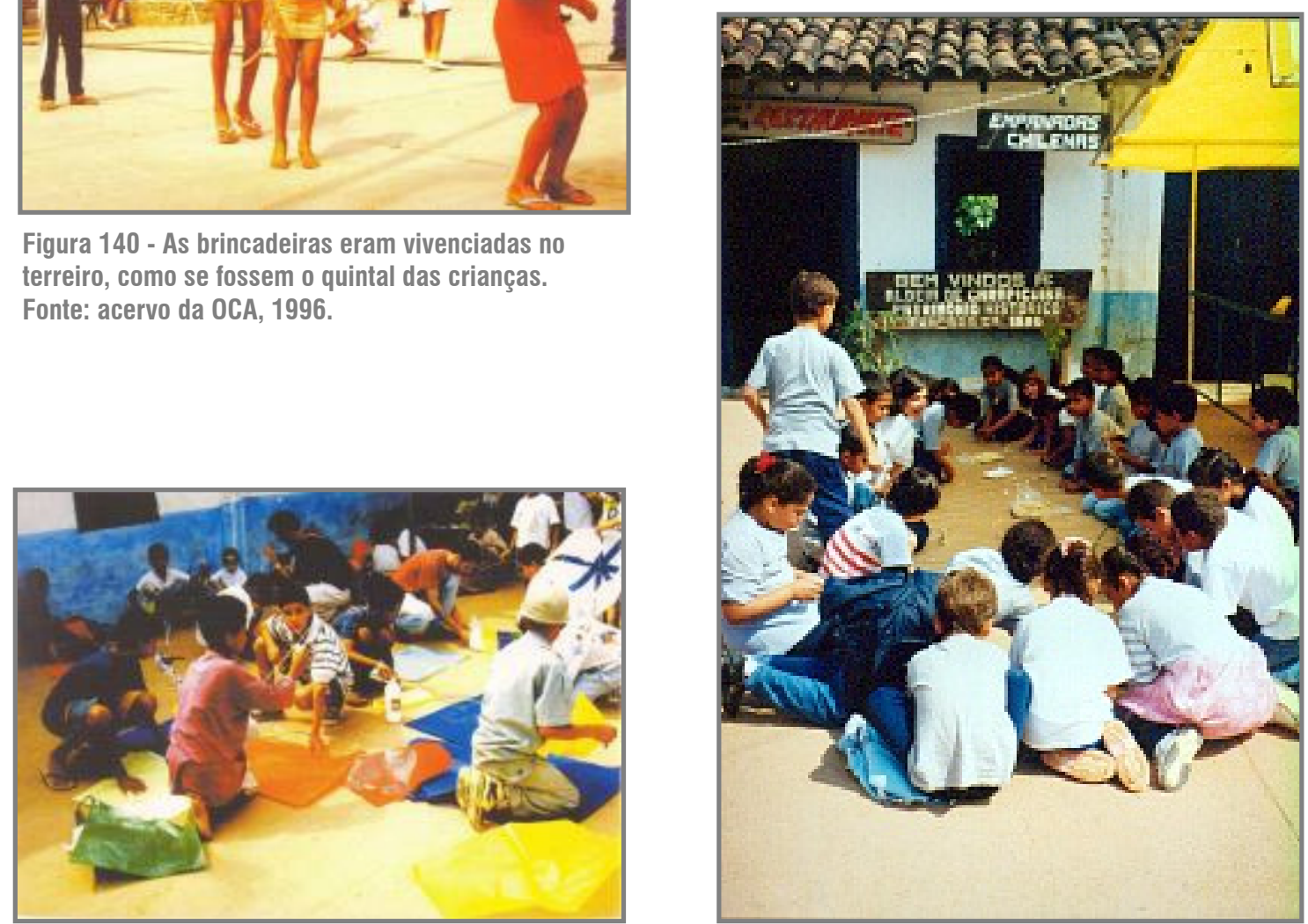

Figura 141 e 142 - 0 espaço da praça da Aldeia sempre muito generoso e acolhedor. Fonte: Acervo OCA, 

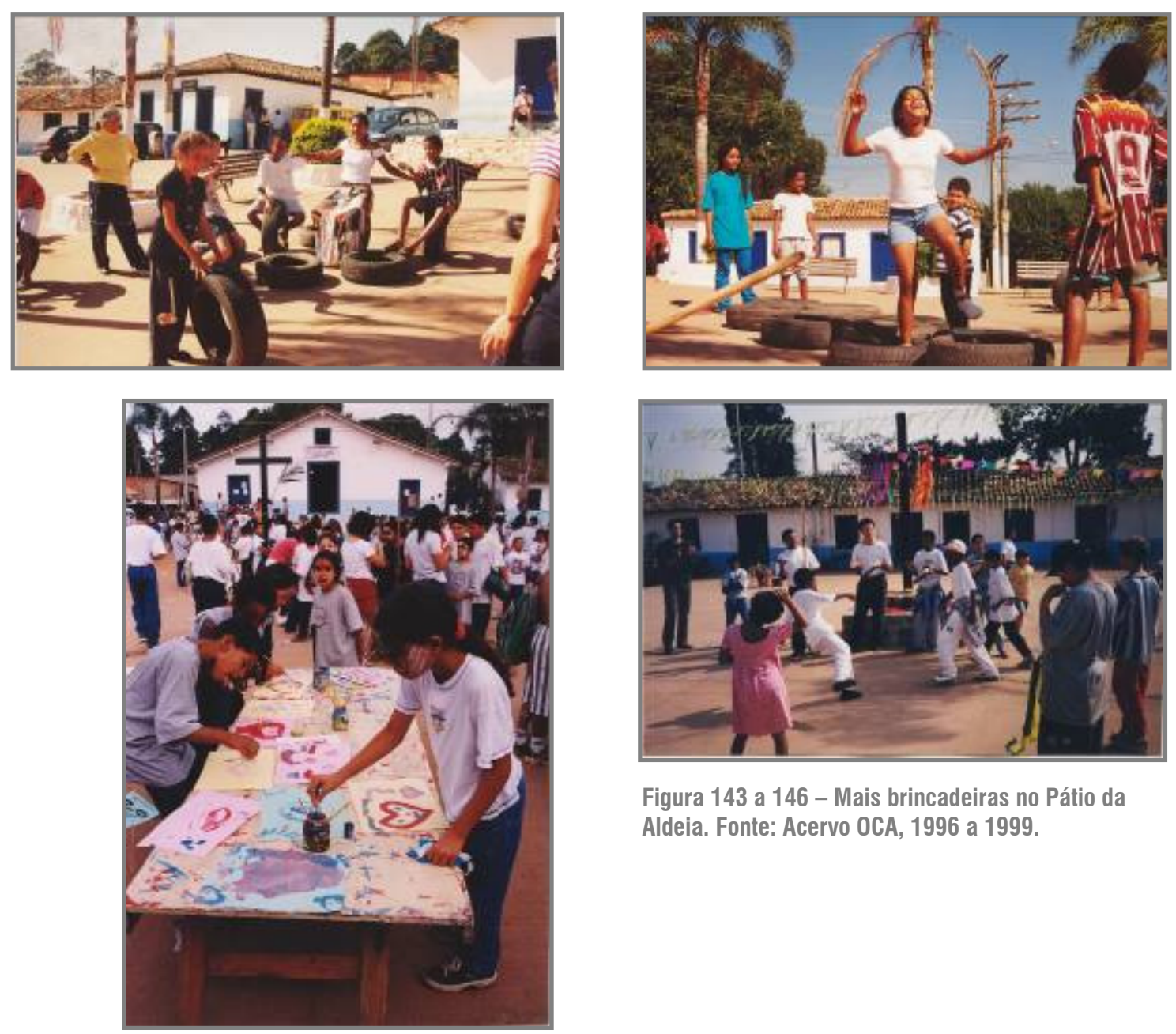

Figura 143 a 146 - Mais brincadeiras no Pátio da Aldeia. Fonte: Acervo OCA, 1996 a 1999. 
1997 a junho de1999 - Sala na Casa da Cultura

Passa a utilizar uma sala nas instalações na Casa da Cultura, (casa XVI do quadrilátero da Aldeia), mas assim mesmo continuava a utilizar o pátio.

Neste período as crianças entraram em contato com outras brincadeiras populares como: 0 Maracatu, Samba de Roda, Maculelê, Guerreiro e Ciranda. A identificação das crianças cresceu junto com o repertório da cultura popular, incentivando a formação do "Grupo Folclórico Meninos e Meninas da Aldeia de Carapicuíba" e com essa nova estrutura, iniciaram apresentações fora do circuito da comunidade.

Com isso, uma professora de dança, Vera Athaíde, e também atriz, é incorporada às atividades de dança e desenvolve a partir das experiências anteriores das crianças, um projeto de pesquisa (com apoio da Fundação Vitae) sob o tema: "Resgate e Fortalecimento da Cultura Popular Brasileira: o trabalho com as crianças da Aldeia de Carapicuíba". A partir desse momento, ocorre um fortalecimento na área artística, desde ensaios mais sistematizados à criação dos próprios figurinos. 
Além das danças populares brasileiras, atividades plásticas aconteciam na sala ou no pátio da Aldeia, sob a coordenação voluntária de uma artista plástica e uma educadora; com a proposta de exercício de trabalhos manuais que desenvolvesse um novo olhar nas crianças para o espaço da Aldeia, utilizando vários materiais e técnicas. Com ainda não contavam com uma estrutura de espaço físico específico para isso, as oficinas foram feitas no terreiro da Aldeia apenas em datas comemorativas, de acordo com o ciclo de festas do ano. 


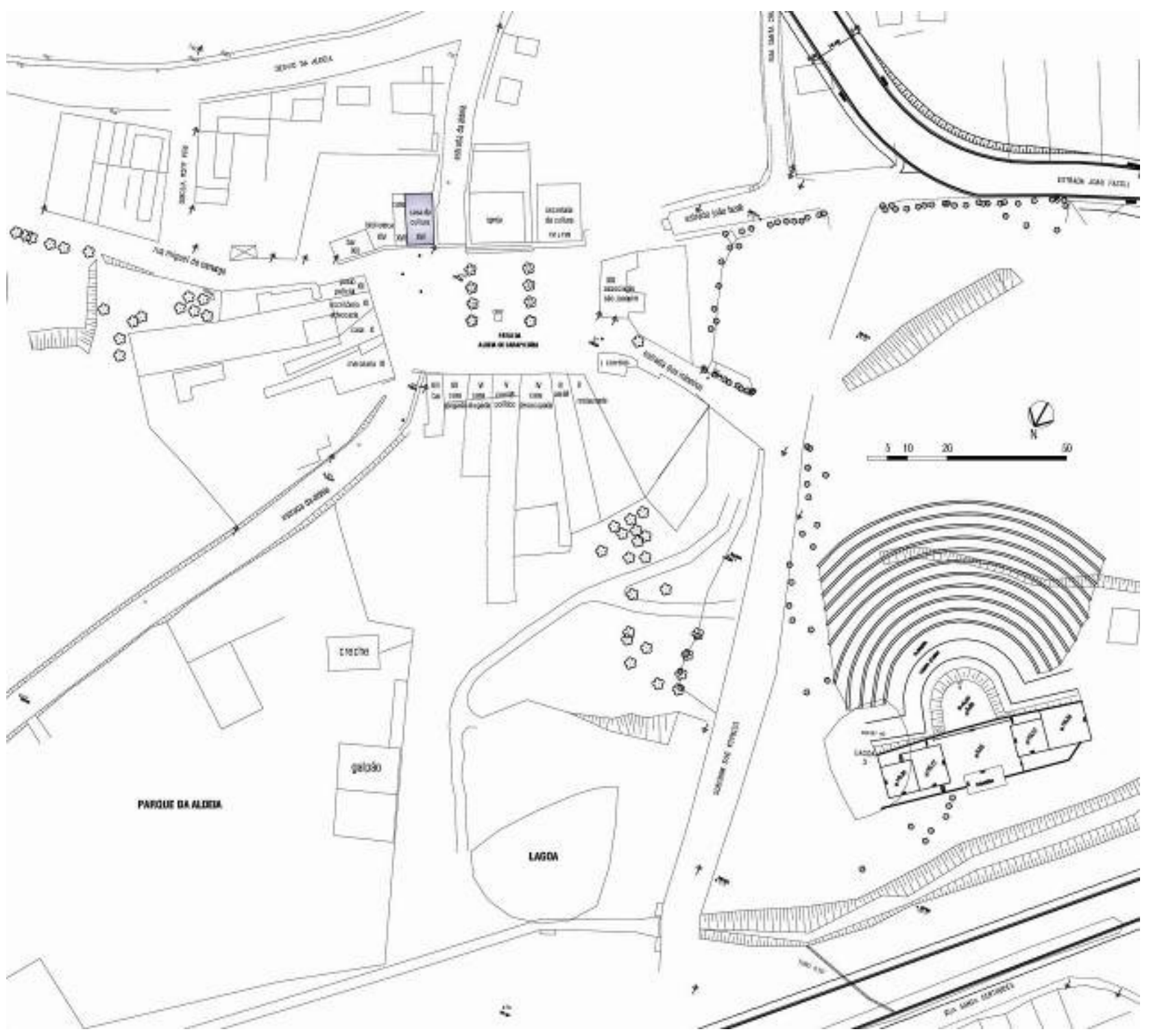

Figura 147 - Já em 1997 a Casa da Cultura abrigava algumas atividades da OCA, mas o Pátio ainda era muito utilizado. Fonte: Acervo OCA. 


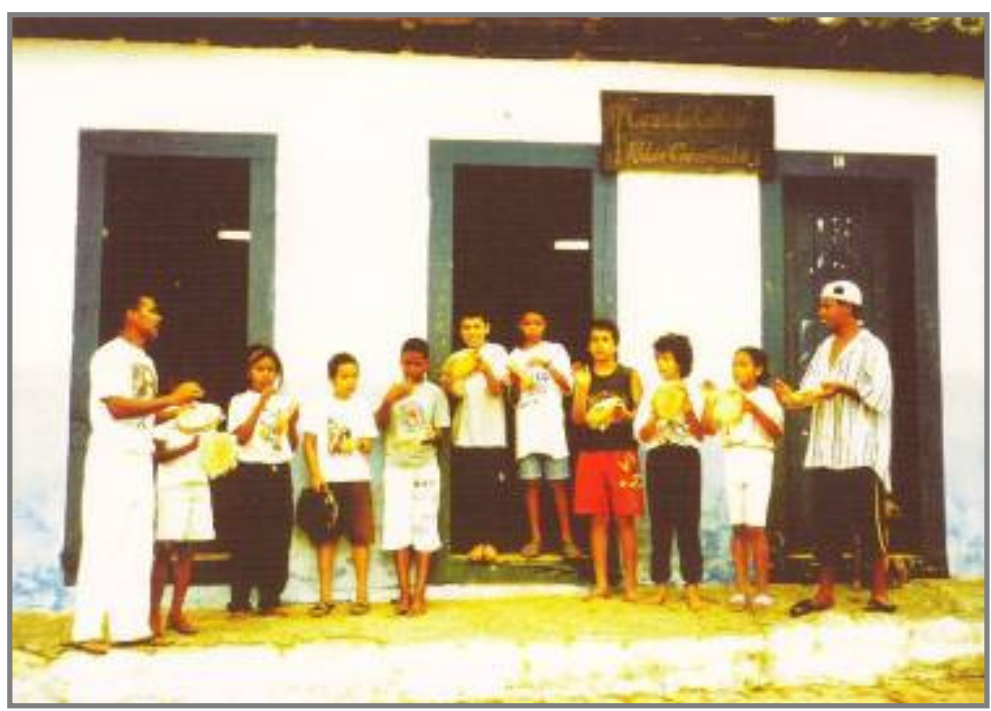

Figura 148 - A OCA na Casa da Cultura. Fonte: acervo OCA.

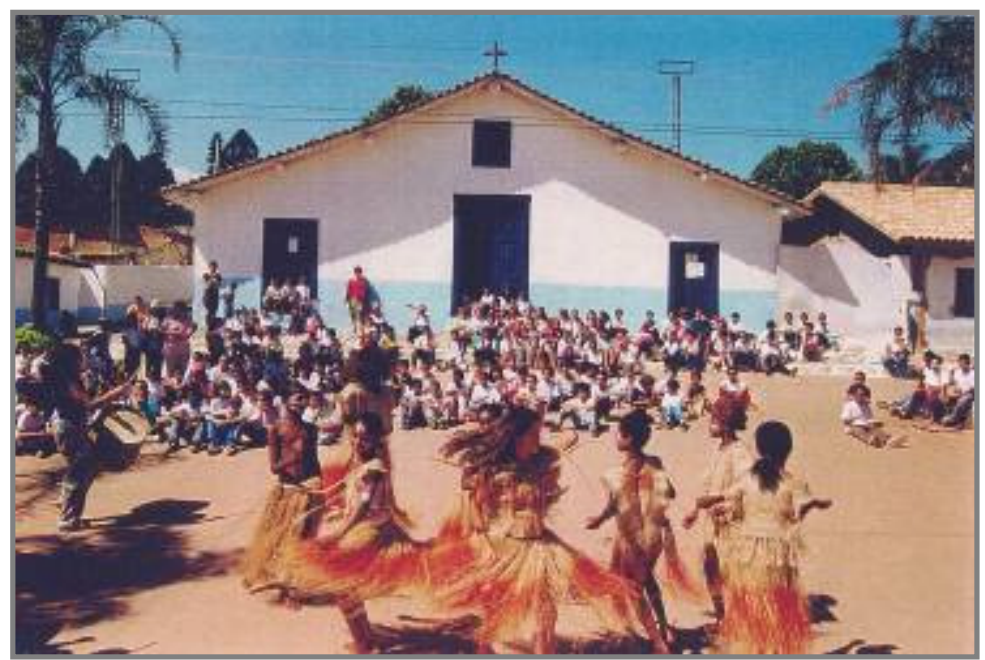

Figura 149 - 0 uso do terreiro da Aldeia para apresentações Fonte: acervo OCA, 1999. 


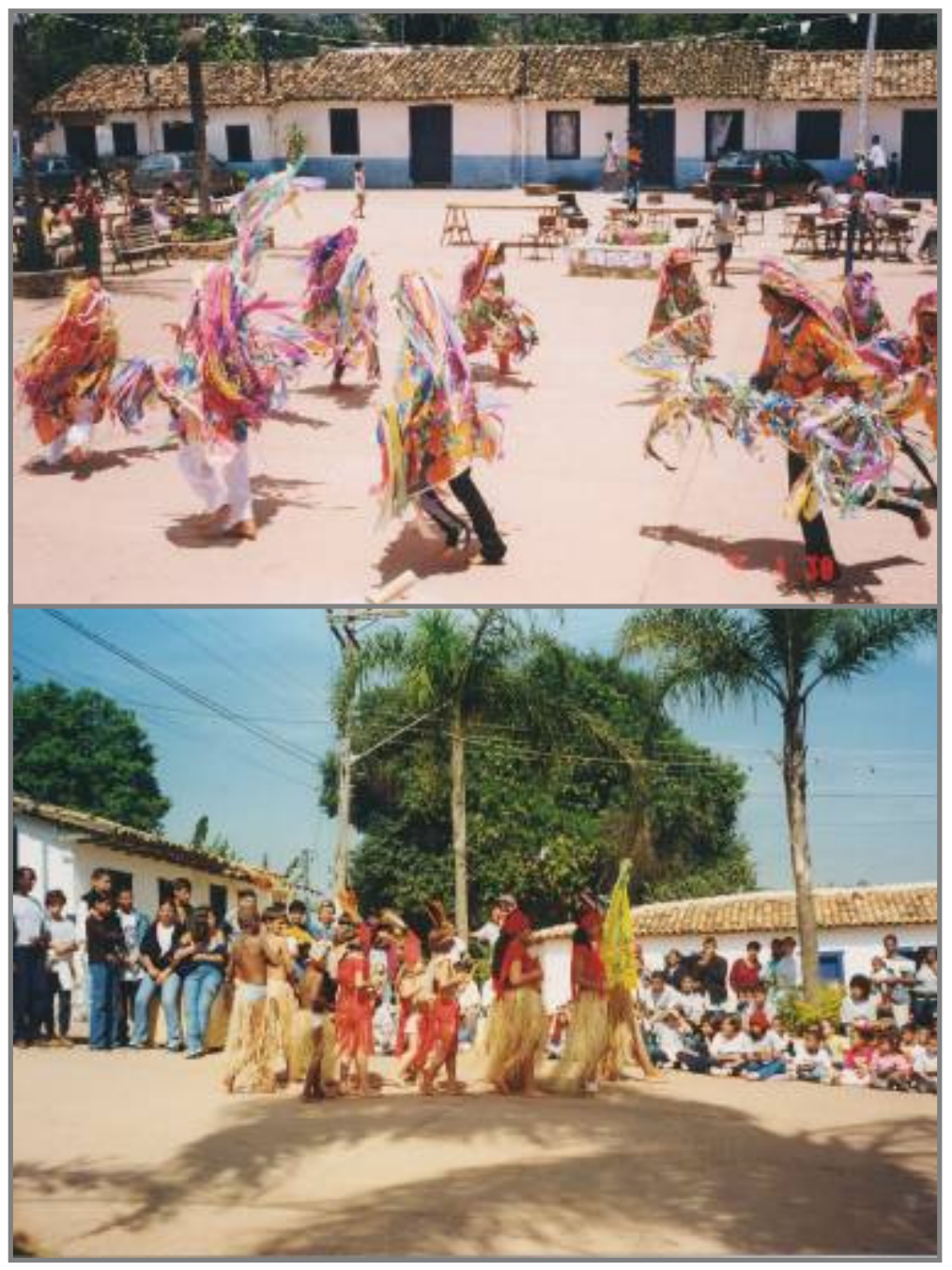

Figura 150 e 151 - Várias apresentações no terreiro da Aldeia .Fonte: acervo OCA. 


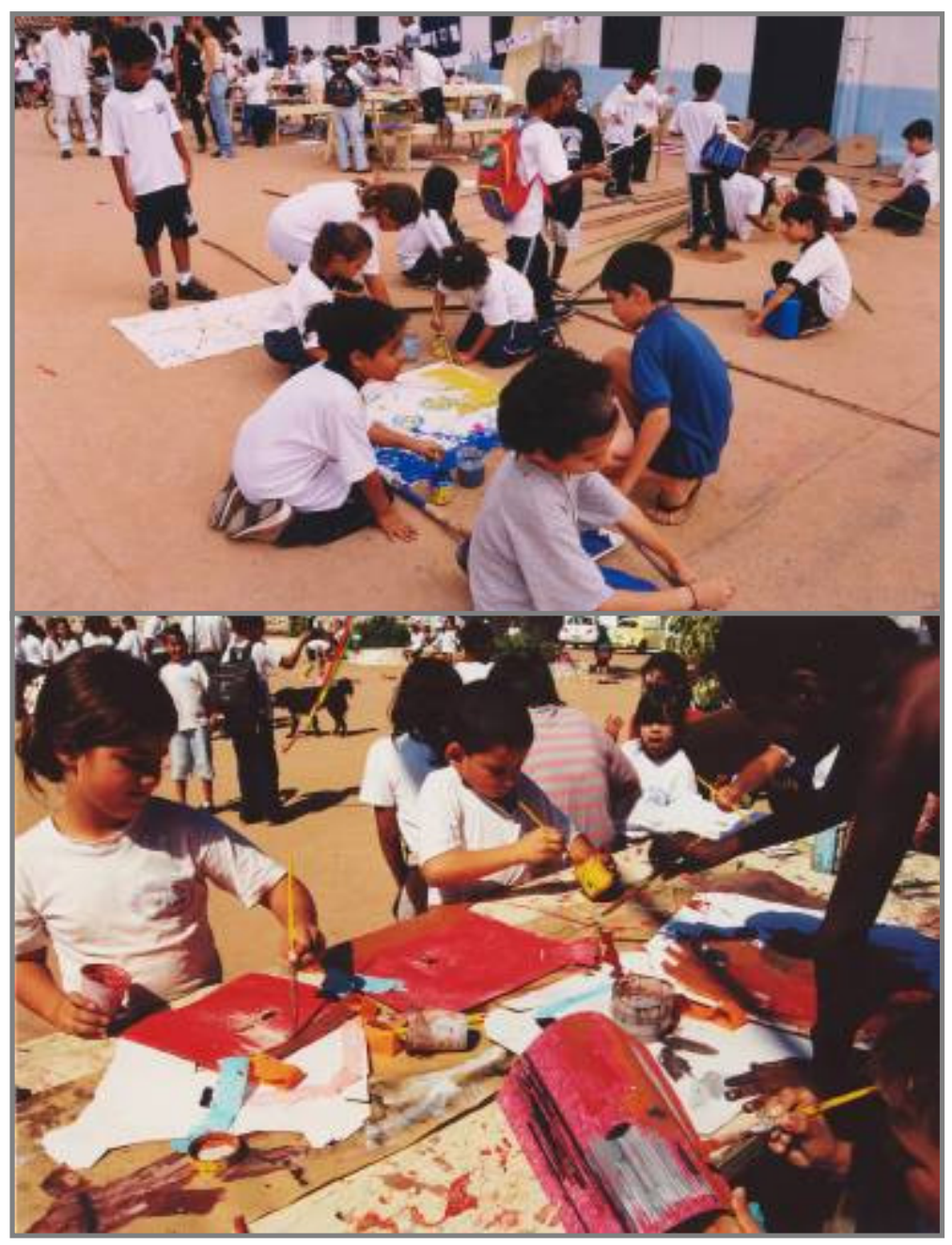

Figura 152 e 153 - 0 "fazer arte" no terreiro da Aldeia .Fonte: acervo OCA. 
Junho de 1999 a 2001 - Casa da Criança

Com 0 fortalecimento do Grupo Folclórico Meninos e Meninas da Aldeia de Carapicuíba, a prefeitura do município cedeu um anexo, ao lado da Casa da Cultura, no acesso ao pátio pela Estrada da Aldeia, chamado de Casa da Criança.

0 espaço foi reformado com a participação da comunidade, sendo que a fachada foi elaborada com mosaico feito pelas próprias crianças como exercício de apropriação do espaço.

Houve um amadurecimento do grupo e das atividades com estudos teóricos sobre frevo e capoeira e a presença de Mestre Kenura - capoeira Angola e do Mestre e percussionista Dinho Nascimento trouxe novos conhecimentos e estímulos às crianças.

No fim de 1999 ocorre a montagem do folguedo popular Cavalo-Marinho, contou com a participação de um brincante da zona rural da Mata de Pernambuco, Edielson que desenvolveu por alguns meses, junto das crianças o folguedo. Foi indicado por Mestre Salustiano - referência na arte da construção da rabeca e do Cavalo-Marinho. 
A vivência da música tornou-se essencial como forma de integração da dança e aproximação mais real das brincadeiras populares brasileiras, assim aconteceram várias oficinas e aulas de percussão.

Como alternativa de fortalecer a parceria entre a música e a dança, está a participação de mais um profissional para criar uma metodologia de aplicação da música popular e a elaboração do processo de aprendizagem, esquematização, e confecção de instrumentos. Posteriormente, a presença constante de um professor de música, o Moxé, e uma professora de artes e artesanais, a Mary, tornam-se primordial.

Assim, inicia-se a busca por um espaço próprio, projetado especificamente para as crianças, suprindo suas necessidades de modo a favorecer a realização plena das atividades. 
Ainda em 99 foi elaborado voluntariamente um primeiro projeto de reforma ${ }^{52}$ em uma casa nos arredores da Aldeia, que não aconteceu porque a edificação foi demolida.

Já em 2001, depois da prefeitura afirmar que iria ceder uma área, inserida no Parque, em comodato para a construção da sede da OCA, foi desenvolvido um novo projeto arquitetônico, mas este projeto também não foi realizado, pois o possível terreno cedido pela prefeitura não comportaria a área que possibilitasse a construção.

${ }^{52}$ Sob coordenação da arquiteta Diana Malzoni. 


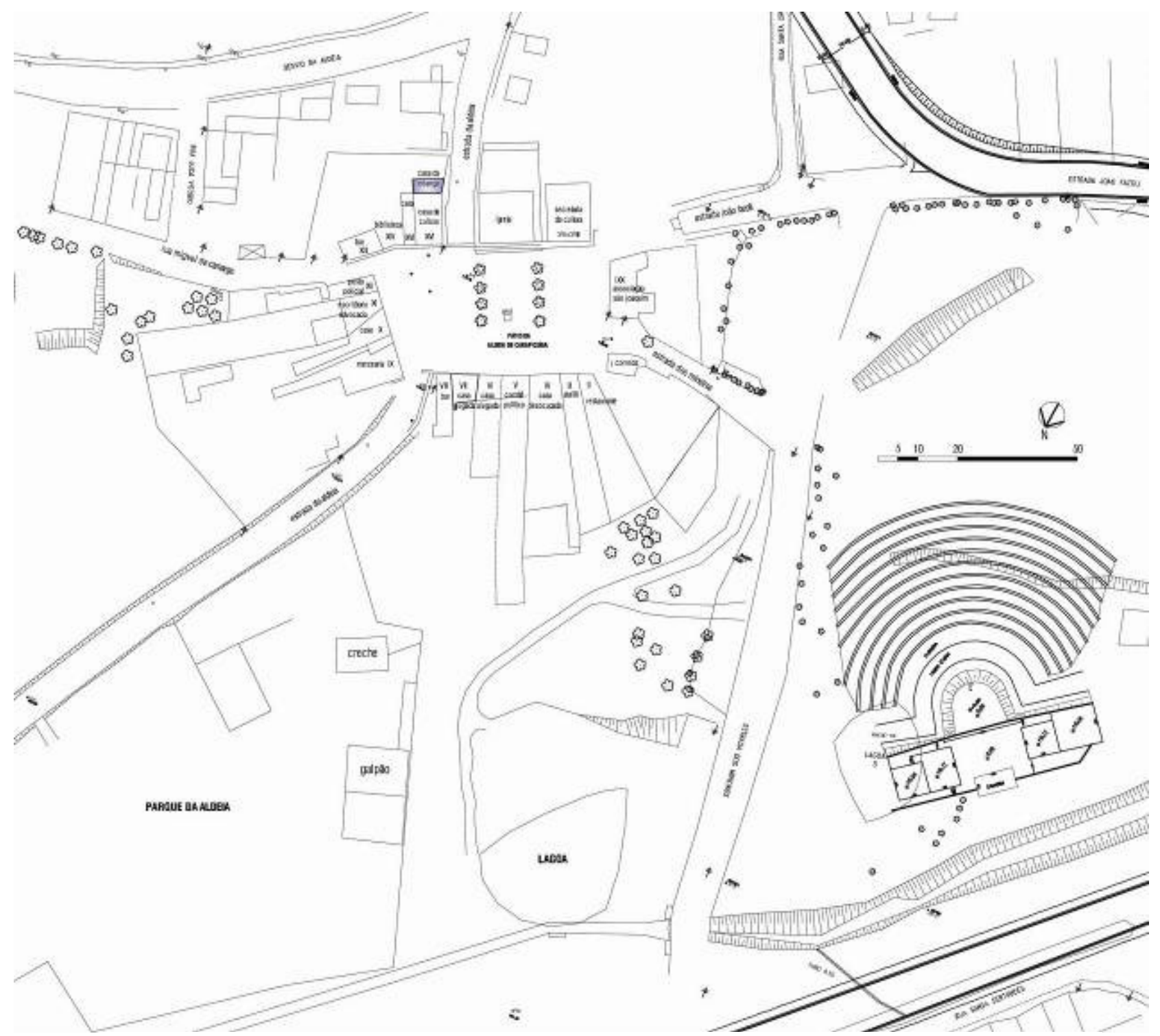

Figura 154 - A Casa da Criança, uma edificação no acesso ao pátio, pela Estrada da Aldeia. Fonte: Acervo OCA. 


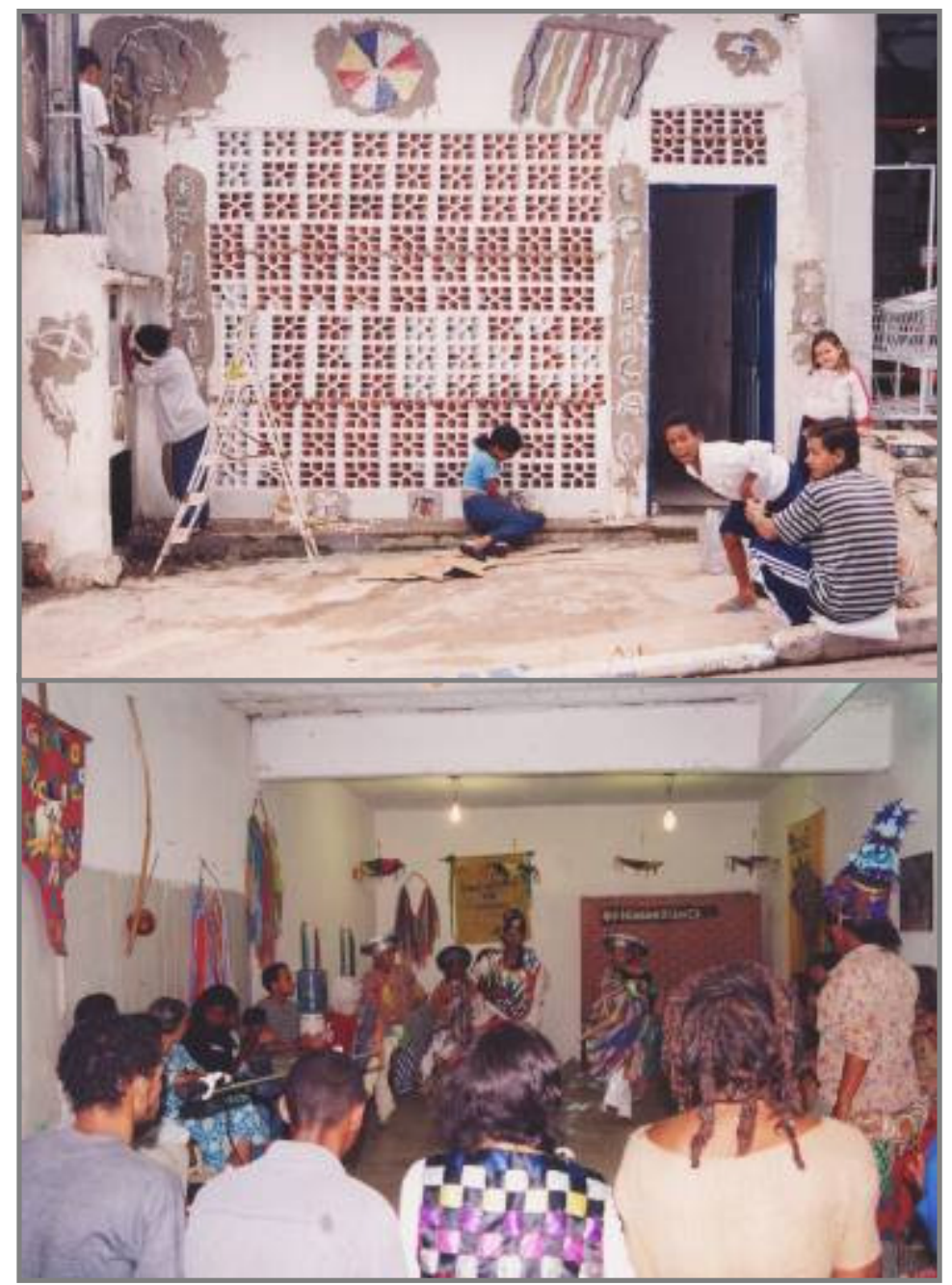

Figura 155 e 156 - Fachada da Casa da Criança e apresentação dentro da edificação. Fonte: Acervo OCA. 

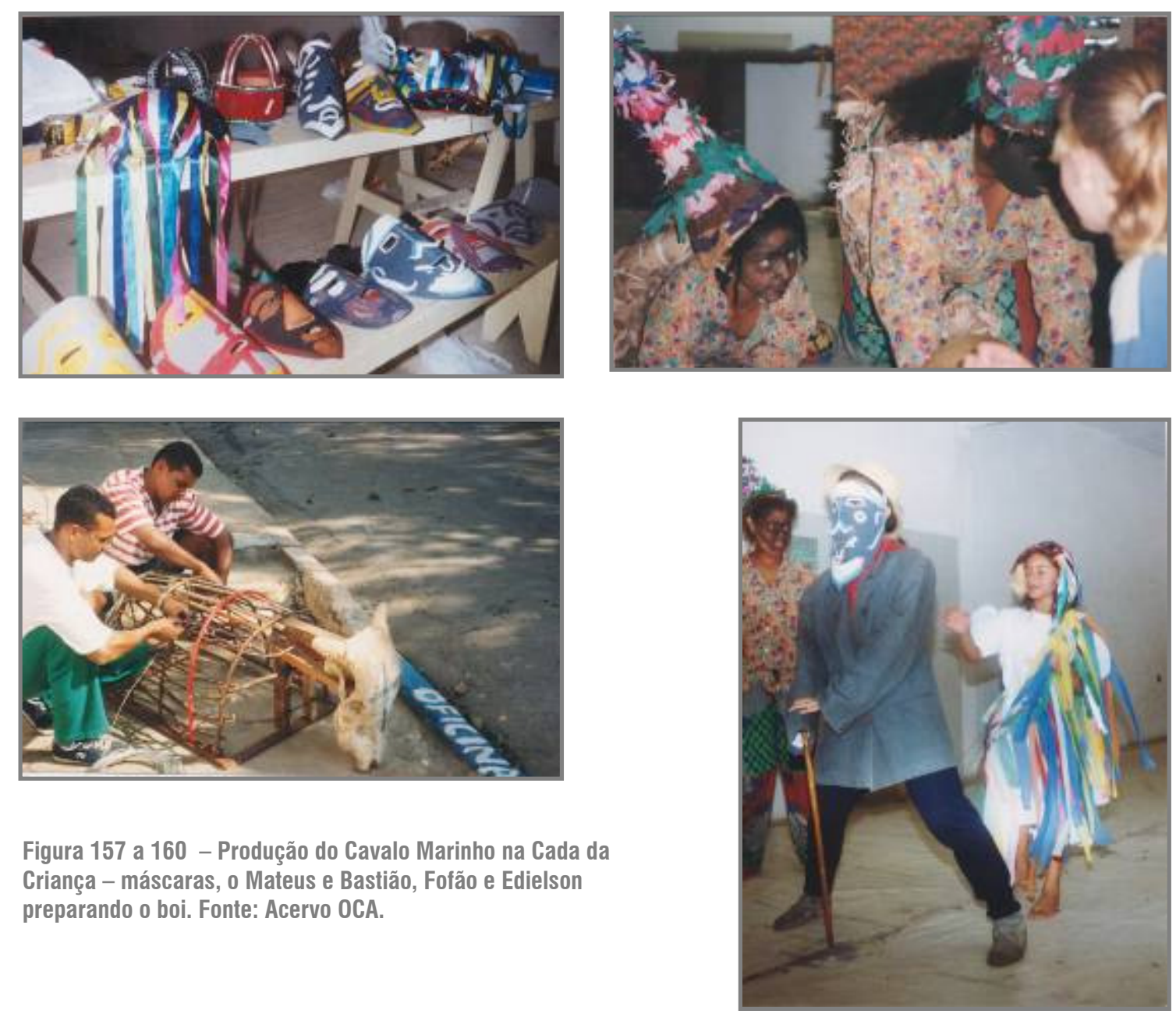

Figura 157 a 160 - Produção do Cavalo Marinho na Cada da Criança - máscaras, o Mateus e Bastião, Fofão e Edielson preparando o boi. Fonte: Acervo OCA. 
2002 a 2007 - Galpão nos arredores da Aldeia

Por um período, as atividades da OCA foram privadas de um espaço, pois a edificação da Casa da Criança teve que ser demolida, uma vez que estava inserida na área de 300 metros delimitada pela Lei de Preservação Histórica. Desta forma, as atividades voltaram a acontecer no terreiro da Aldeia.

Foi então que a prefeitura cedeu provisoriamente um galpão próximo à Aldeia, desapropriado, inserido no perímetro da Zona de Preservação, portanto na área do Parque Cultural.

Com o aumento de espaço para as atividades, houve um aumento significativo no número de crianças participantes. Apesar do galpão ter área maior que todos os outros espaços ocupados, a edificação era precária e com pouca estrutura de uso. Além das atividades, as crianças eram alimentadas diariamente com almoço no período da manhã e lanche no período da tarde para cumprir a deficiência alimentar que muitas crianças tinham. 
Além disso, surgiram outras solicitações voltadas ao aprimoramento da linguagem devido a deficiente aprendizagem, deixando claro a presença constante de uma educadora, Lucilene, educadora incorporada nas atividades do dia-a-dia da OCA para entender as dificuldades reais das crianças.

Assim, ocorre uma nova dinâmica com o início do reforço escolar depois das brincadeiras, alfabetização de jovens e adultos, acompanhamento e formação de monitores e a extensão das atividades, principalmente brincadeiras, da OCA para as escolas públicas da comunidade durante o recreio escolar.

Outra atividade que foi incorporada na dinâmica da OCA foi um conjunto de mães das crianças que começaram a se reunir para cantar e contar histórias, e durante esse processo, elas costuram, bordam e fazem artesanatos. Esse encontro gerou um grupo coeso de mães que hoje produzem artesanatos diversos para complementar suas rendas. 
Em 2003 é formalizada a criação do Centro de Estudos e Irradiação da Cultura Infantil e desde 2004 a OCA é selecionada pelo Ministério da Cultura para ser Ponto de Cultura ${ }^{53}$.

Em 2006, a prefeitura formaliza a transferência da área do galpão para a OCA em comodato de 20 anos, com isso inicia-se um esforço para a construção da sede própria no referido terreno e um novo projeto arquitetônico é concebid054. A construção é iniciada em 2007 (terreno nos fundos do galpão), com ajuda de colaboradores e diversas doações, desde materiais até desenvolvimento de projetos.

\footnotetext{
53 "O Ponto de Cultura é a ação prioritária do Programa Cultura Viva e articula todas as demais ações do Programa Cultura Viva. É responsável por articular e impulsionar as ações que já existem nas comunidades. Atualmente, existem mais de 650 Pontos de Cultura espalhados pelo país e, diante do desenvolvimento do Programa, o MinC decidiu criar mecanismos de articulação entre os diversos Pontos, as Redes de Pontos de Cultura e os Pontões de Cultura.

0 Ponto de Cultura não tem um modelo único, nem de instalações físicas, nem de programação ou atividade. Um aspecto comum a todos é a transversalidade da cultura e a gestão compartilhada entre poder público e a comunidade."

${ }^{54}$ Projeto voluntário, arquitetura: arq. Lucia Mayumi Hashizume; concepção e cálculo estrutural eng ${ }^{\circ}$ Yopanan Rebello.
} 


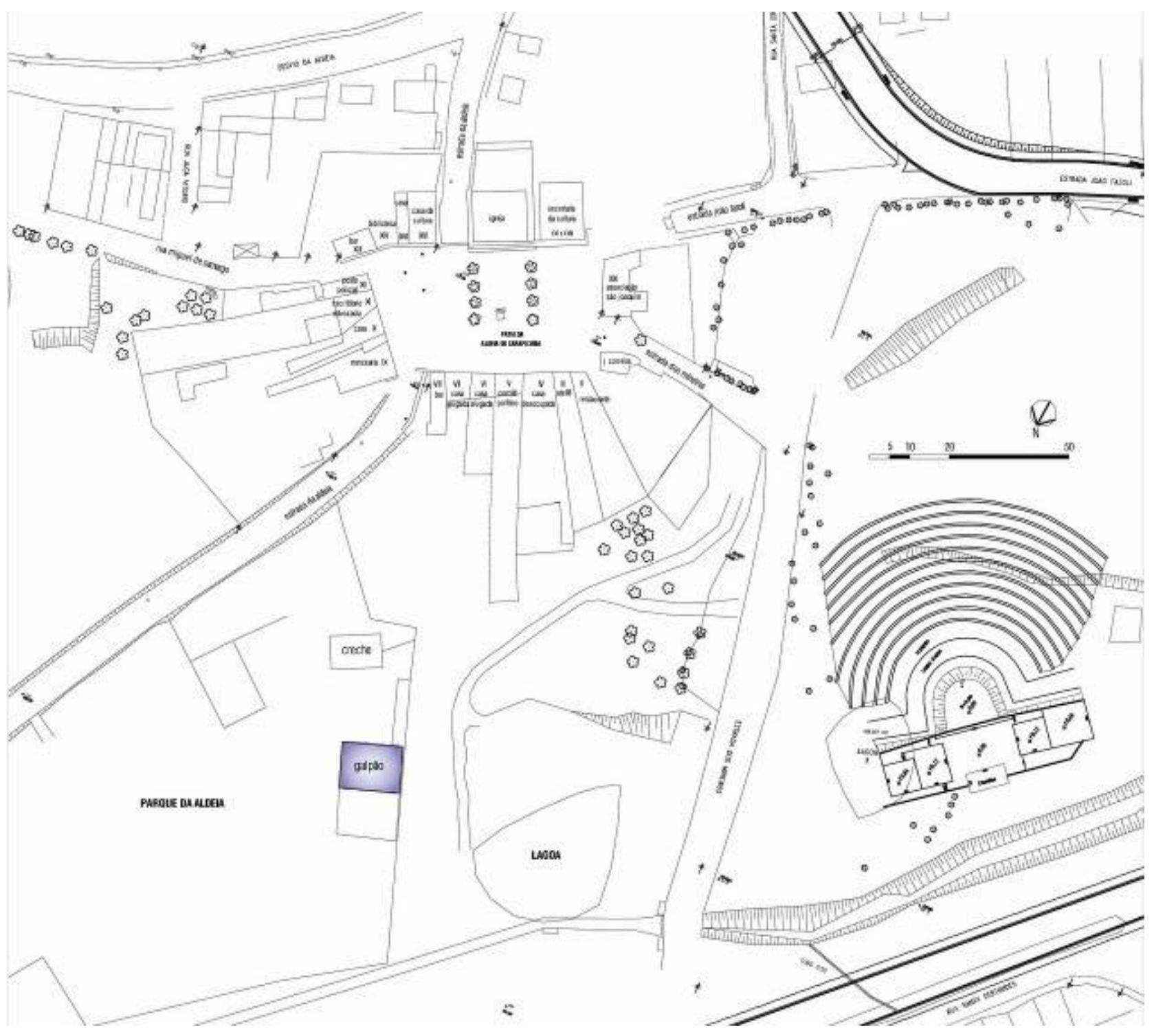

Figura 161 - Implantação do galpão nos arredores do Pátio da Aldeia que abrigou a OCA de 2002 a 2007. 

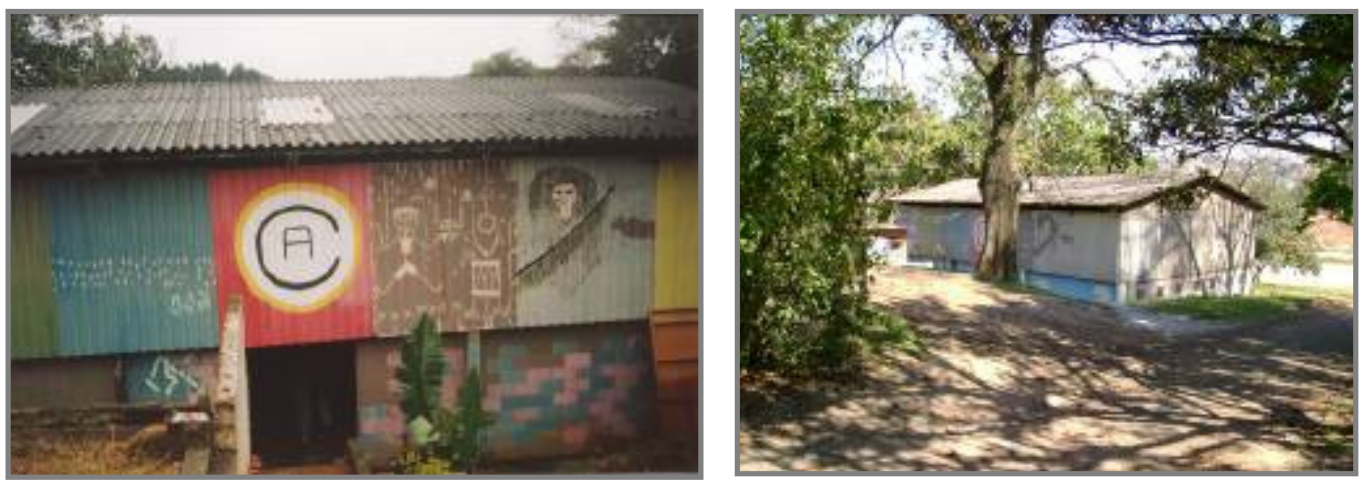

Figura 162 e 163 - Fachada do galpão e vista lateral. Fonte: Acervo OCA e arquivo pessoal, 2007.
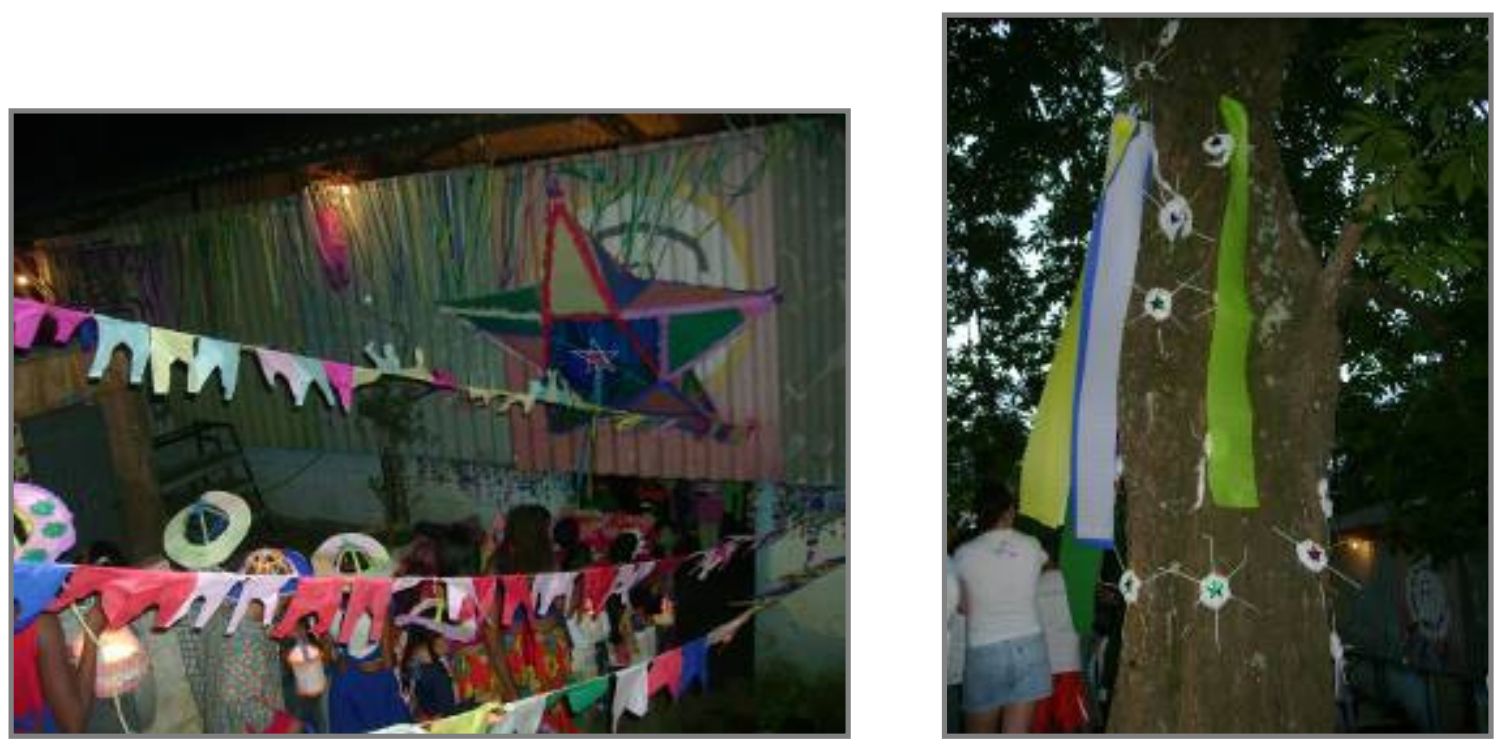

Figura 164 e 165 - Galpão decorado para Festa de São João. Fonte: Acervo arquivo pessoal, 2007. 

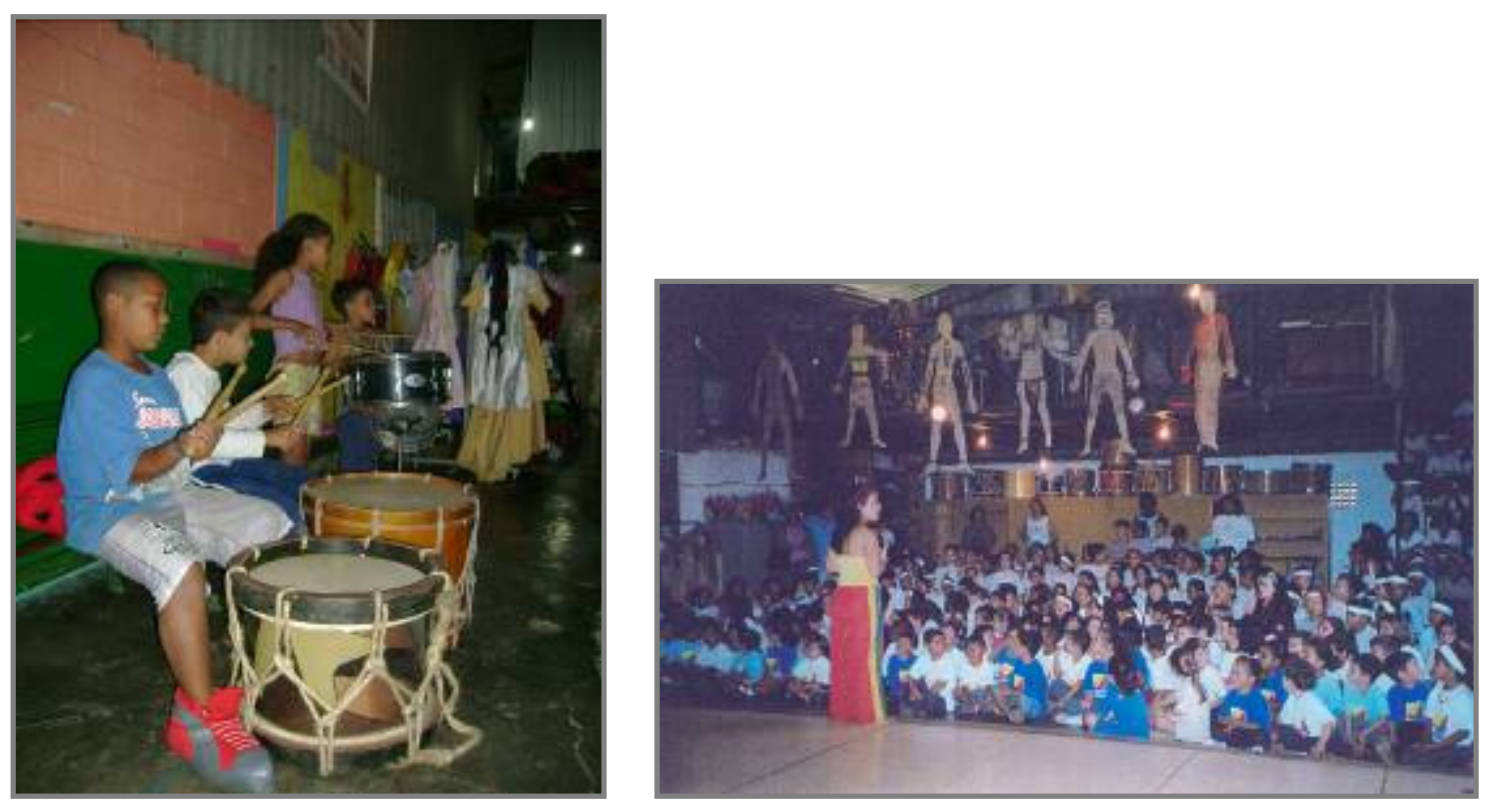

Figura 166 e 167 - Atividades dentro dentro do galpão. Fonte: arquivo pessoal, 2007 e acervo OCA.

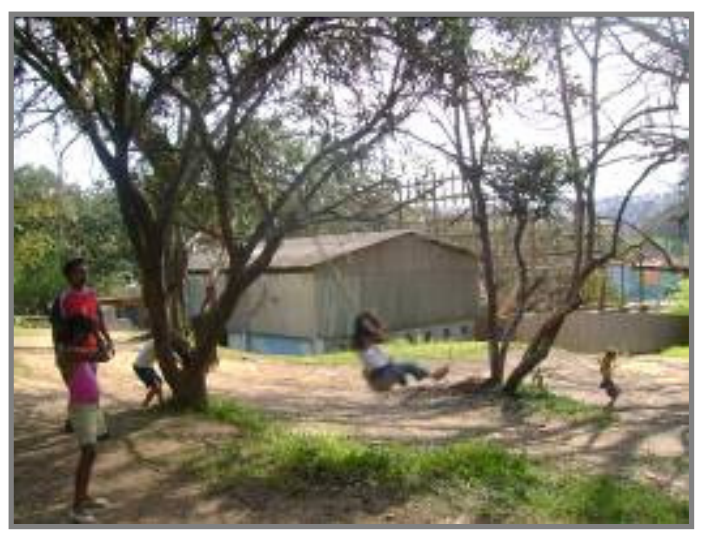

Figura 168 - 0 brincar na área externa do galpão. Fonte: arquivo pessoal, 2007.

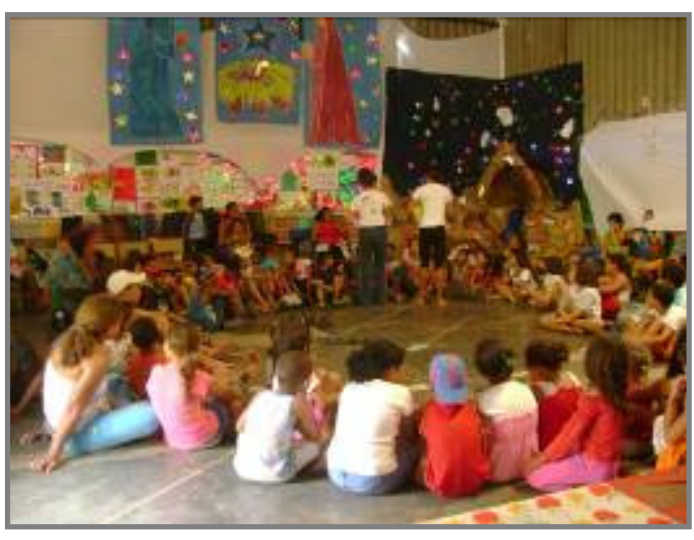

Figura 169 - Atividade de leitura no interior do galpão. Fonte: arquivo pessoal, 2007. 


\subsubsection{0 espaço construído para as crianças}

A realização parcial da construção possibilitou a mudança para o novo espaço, concretizada no início de 2008.

A primeira etapa construída da edificação dispõe no pavimento térreo de salão multiuso, cozinha, despensa, sala de materiais e brinquedos e vestiário feminino e masculino. Já o pavimento superior é formado por biblioteca com área para acervo de livros, estudo e computadores, sala dos instrumentos e indumentárias, sala de artes, saleta de atendimento individual, sala de costura e dormitório do vigia.

0 projeto arquitetônico foi desenvolvido pela arquiteta Lucia Mayumi Hashizume e a concepção e cálculo estrutural de madeira roliça foi elaborado pelo engenheiro Yopanan Rebello. A construção contempla o uso de matérias tradicionais: cobertura com telhas de barro do tipo capa e canal, estrutura de madeira roliça de reflorestamento, laje e vedações em concreto celular e piso de cimento queimado. 
Com o uso do novo espaço, as atividades desenvolvidas ao longo dos anos pela OCA sofreram adaptações para uma nova dinâmica, ocasionada pelo crescimento de área, e até pela fragmentação espacial - implantação da biblioteca, saleta de artes e costura em salas separadas de todo o contexto - além do aumento expressivo do número de crianças.

Apesar das adequações na maneira de usar o espaço, as crianças se apropriaram rapidamente da arquitetura pensada para elas; fato constatado pela observação dos movimentos espontâneos nas brincadeiras, sem qualquer problema no uso do espaço.

0 desenho favoreceu. A construção se abre do salão multiuso para o Parque por meio do grande gramado na frente, ladeado por árvores, terra e areia - um quintal com muitos brinquedos oferecidos pela natureza, um verdadeiro espaço lúdico.

Chama a atenção para as áreas adjacentes à nova implantação da OCA que ainda não são utilizadas pela comunidade do entorno, como exemplo 0 anfiteatro ao ar livre construído junto com o Parque que é usado apenas uma vez por ano na encenação Paixão de Cristo. As 
áreas ainda carecem de infra-estrutura básica, segundo a prefeitura, muitas delas ainda estão em fase de desapropriação, impedindo a finalização total da obra.

0 surgimento da OCA, por meio das atividades, na Aldeia de Carapicuíba, instaurou novos modos de usos do espaço do terreiro propriamente dito; e aos poucos foi irradiando para 0 entorno - 0 Parque. A partir disso, cria-se um novo conceito: 0 de Aldeia Parque, território estabelecido pelas ações reais e efetivas das crianças nesse contexto. 


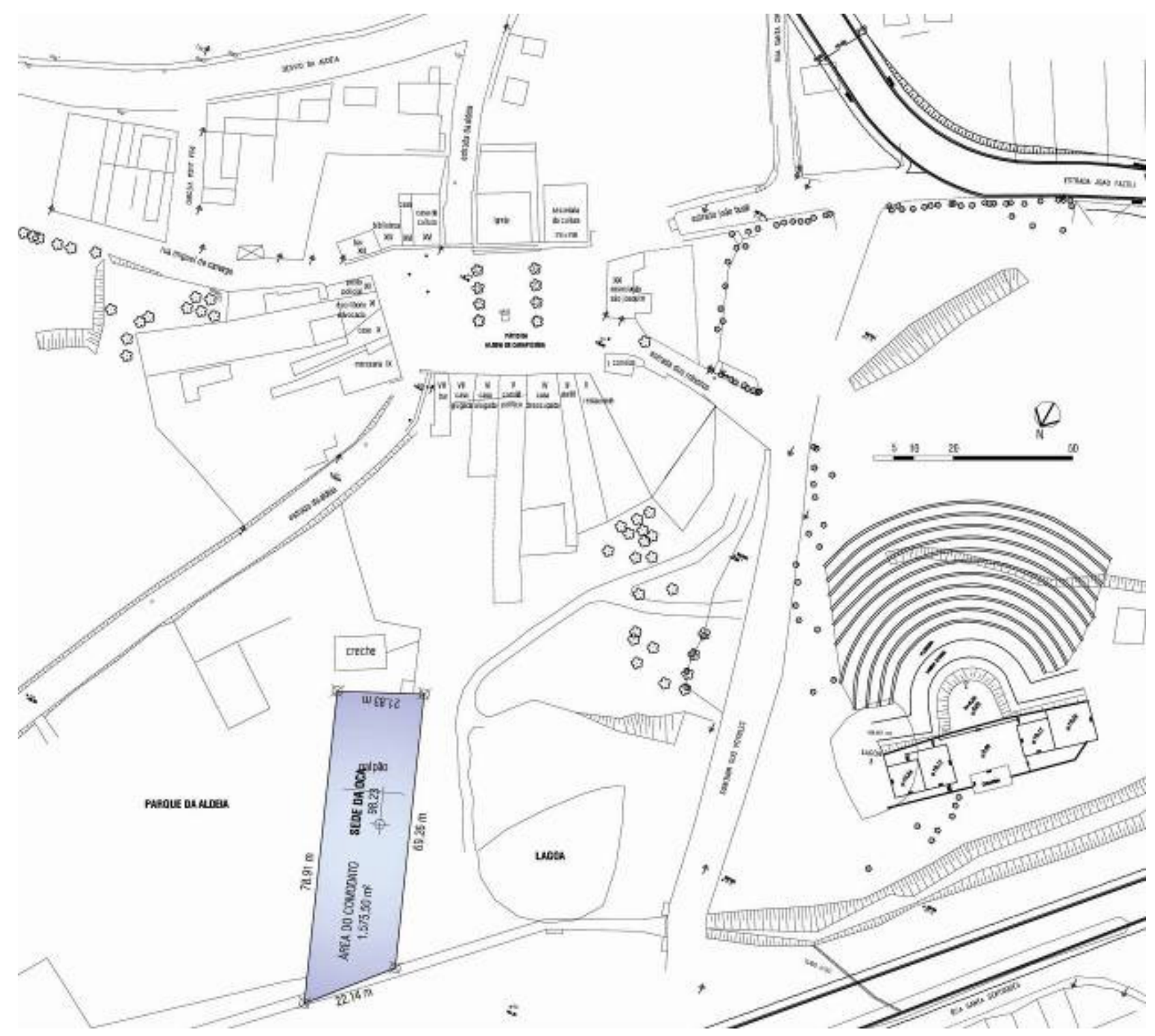

Figura 170 - Implantação da nova sede da OCA projetada pela arquiteta Lucia Mayumi Hashizume para abrigar 0 território sagrado das crianças. 


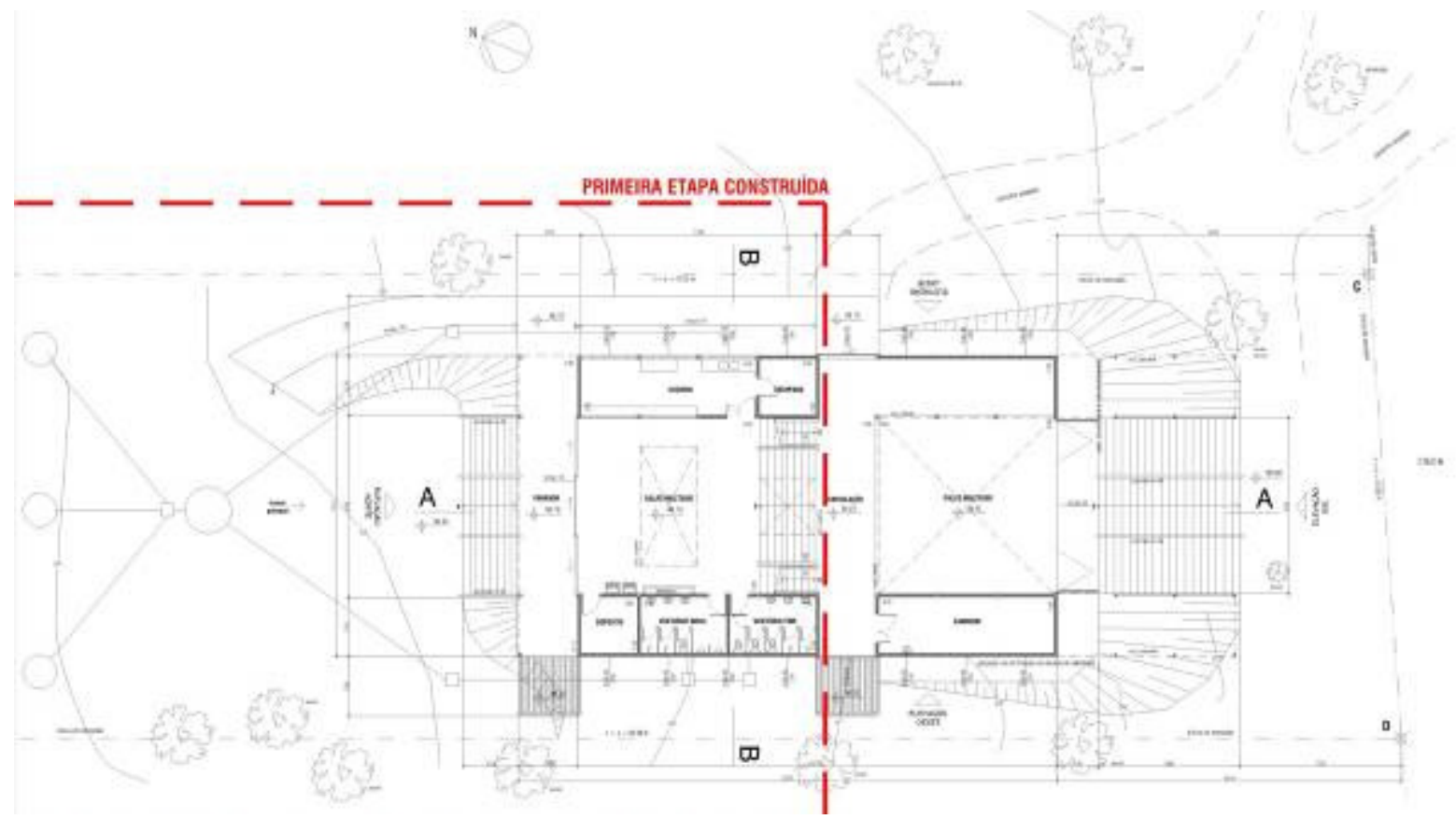

Figura 171 - OCA Planta Térreo. Fonte: arq. Lucia Mayumi Hashizume, 2006.

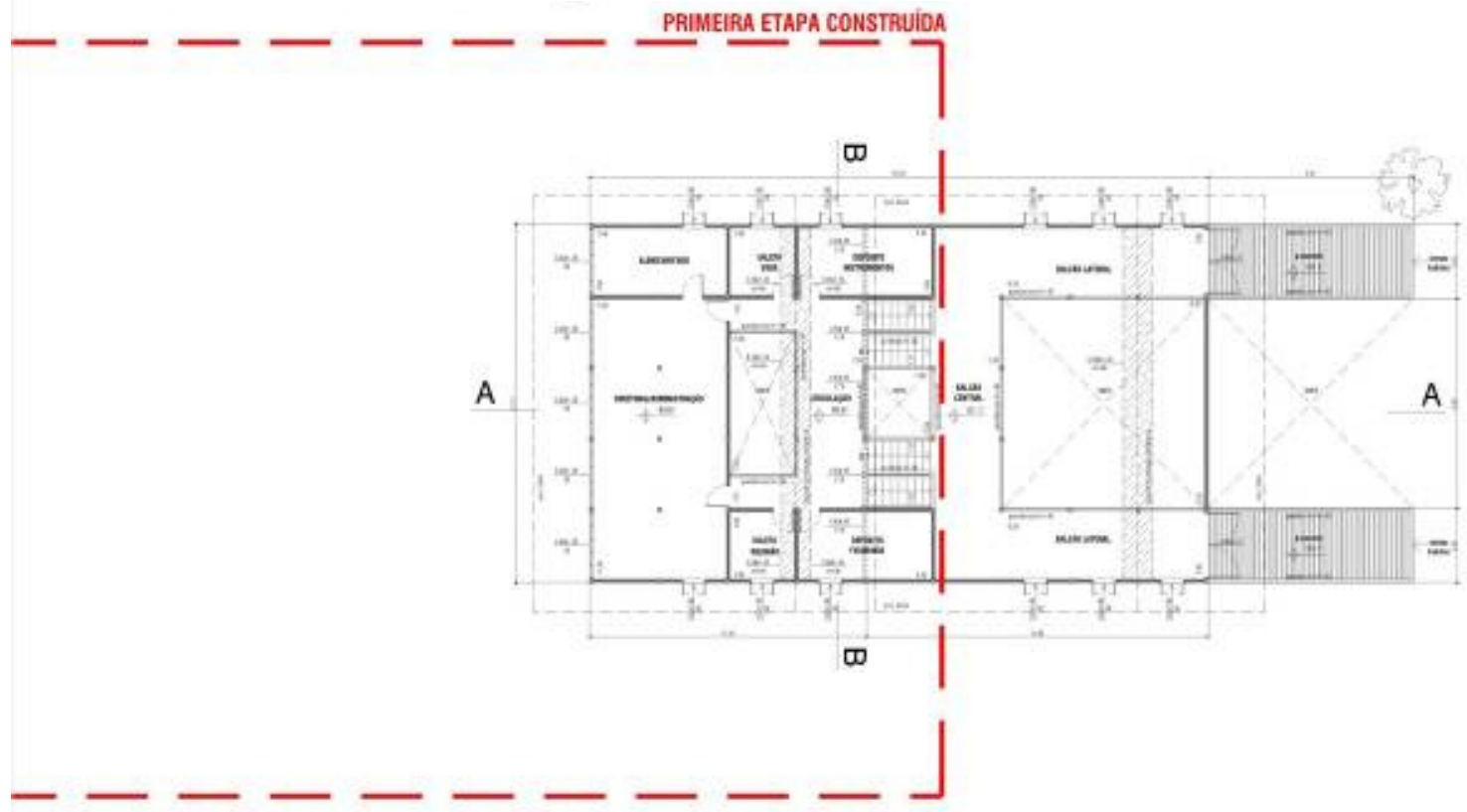

Figura 172 - OCA Planta Superior. Fonte: arq. Lucia Mayumi Hashizume, 2006. 

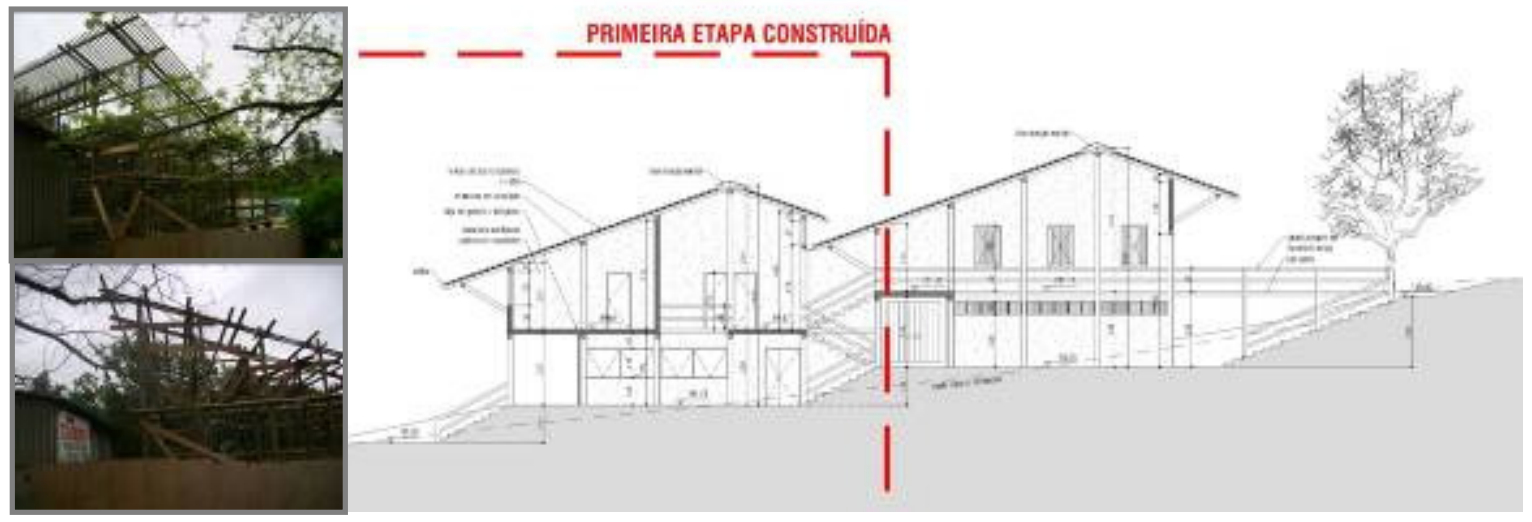

Figura 173 - OCA - Corte AA. Fonte arq. Lucia Mayumi Hashizume, 2006.

Figura 174 e 175 - Durante a obra. Fonte: arquivo pessoal, 2007.
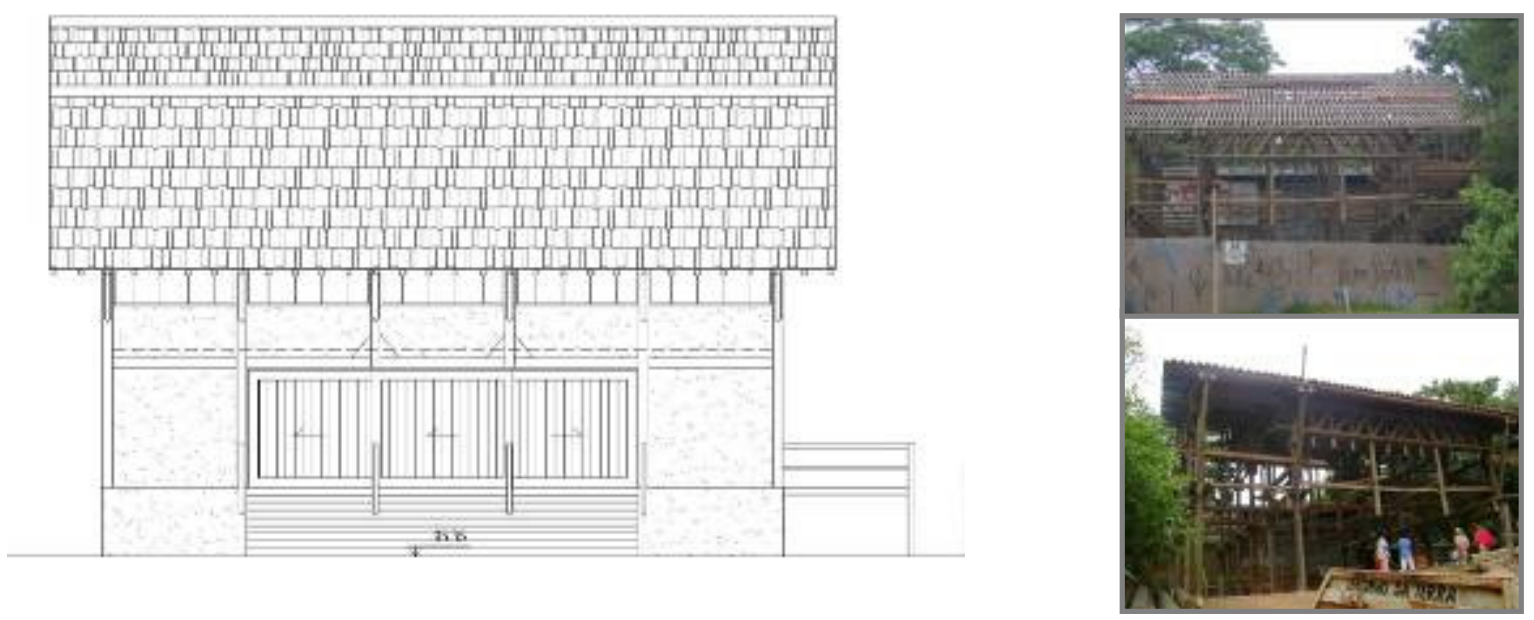

Figura 176 - OCA - Elevação Norte. Fonte arq. Lucia Mayumi Hashizume, 2006.

Figura 177 e 178 - Durante a obra. Fonte: arquivo pessoal, 2007. 

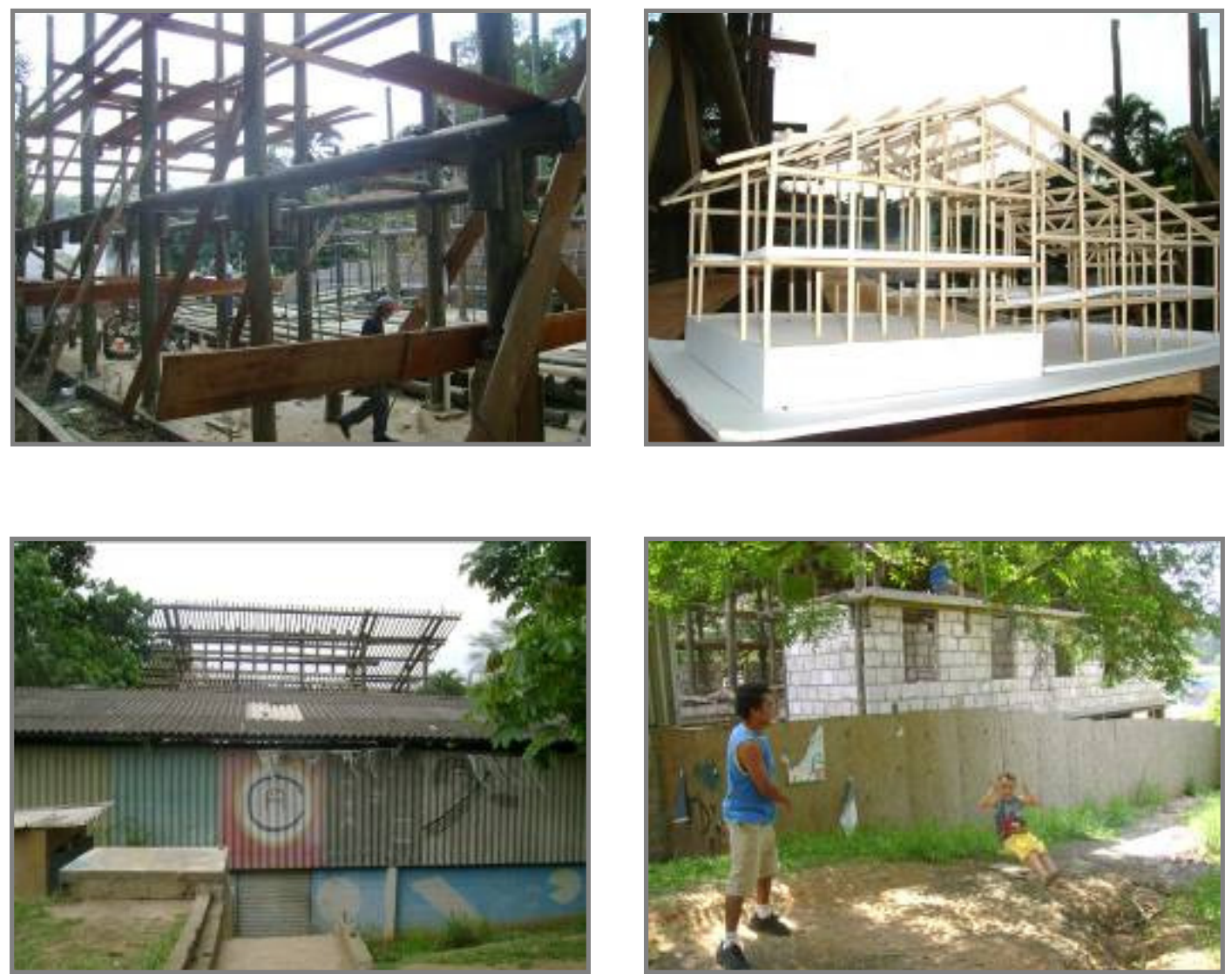

Figura 179 a 172 - Durante a obra. Fonte: arquivo pessoal, 2007. 
$O C A$

Uma construção com materiais tradicionais, telhados de telha capa e canal, estrutura de madeira roliça renovável. Vedações e lajes de piso em concreto celular, leves e resistentes, acrescentando aos materiais tradicionais uma boa contribuição dos materiais industrializados.

Um jogo de armar leve sobre o solo, com fundações diminutas, basicamente baldrames para as divisórias nos térreos.

Uma obra não expansível, de um tamanho ótimo para as atividades a abrigar. Se for necessário crescer, se faz outra construção independente e não contígua.

Essa definição construtiva, simples, com custos módicos, com contribuição de trabalho dos interessados, procura ser apropriada pelos usuários e fazer parte de seu universo e seu imaginário.

Simples, mas não simplista. No jogo geométrico proposto, apresenta um grande salão em três níveis, antecedido sempre por escadarias-arquibancadas, com 8,40 m de largura por 36,40 m de comprimento, com três iluminações zenitais, quatro entradas laterais, duas de cada lado e duas grandes entradas nas extremidades. 
Espaço que pode ser usado no seu todo por uma única atividade ou que pode ser dividido em várias atividades: danças, brincadeiras e oficinas, por exemplo. Em certas horas do dia, parte será refeitório, parte será para aulas, parte será para treinamentos. Em outras horas, poderá servir para reuniões grandes, para performances e para concentração, meditação, relaxamento e cultura do corpo. Uma variedade grande no decorrer de um dia

Percorrê-lo com as luzes de cima e dos lados, com as escadarias suaves e seus patamares será algo com ritmo cheio de paz, cheio de dimensões visuais diferentes e consumindo um certo tempo dada a sua dimensão longitudinal maior. Um tempo de paz e alegria.

Seus andares superiores, sempre em balcões, possibilitam visualizar o espaço em conjunto, servem de local para a platéia poder descortinar o que se passa e permite a privacidade para as atividades mais centradas: a leitura, o uso dos computadores, os encontros, reuniões e aulas para menos gente.

Abaixo dos balcões os serviços específicos: os camarins, os vestiários e banheiros, a cozinha, os depósitos e o que mais for necessário.

A edificação se abre para a avenida abaixo, para o acesso à praça da Aldeia acima, para o bosque de um lado, para o teatro ao ar livre, e para o lago do outro. 
Seus percursos internos serão sempre circulares, sem ter que se ir e vir pelo mesmo caminho, com uma grande interação do que é interno com que é externo.

Esses percursos podem ser seletivos e abertos ou fechados conforme as horas do dia e da noite. 0 conjunto construído uma vez fechado será estanque, não havendo a necessidade de muros ou pátios externos. As marcas divisórias serão formadas por grupos de vegetação e por elementos construídos que se constituem em mobiliário para o uso de todos.

Uma grande galeria equipada, articulada e aberta quando se desejar e se fizer necessário. Um espaço de dimensões inusuais para o casario do entorno, constituindo-se em referência boa, promotora de auto-estima e valorização para seus usuários e para os moradores da cidade à volta.

Um lugar de alegria, de liberdade, de crescimento, de sociabilidade, de procura e encanto daquilo que faz maior e melhor a vida de cada indivíduo, das pessoas e dos grupos maiores e menores de crianças, de mulheres e de homens, de idosos, de todos aqueles que compõem uma sociedade.

0 autor

Carapicuiba, 20 de fevereiro de 2006. 


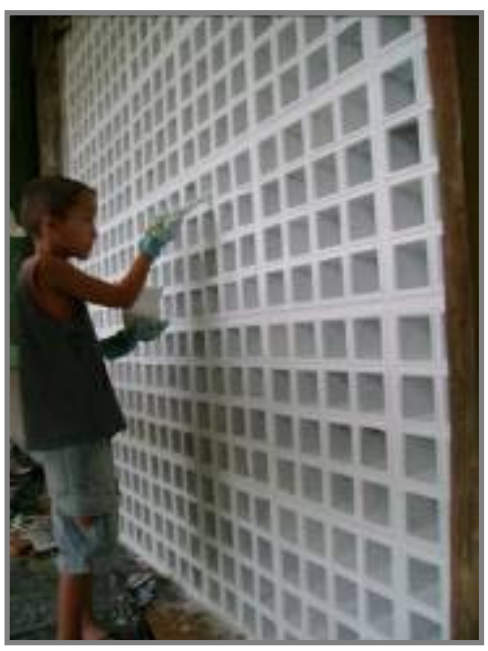

Figura 173 - 0 mutirão para a pintura. Fonte: arquivo pessoal, 2008.

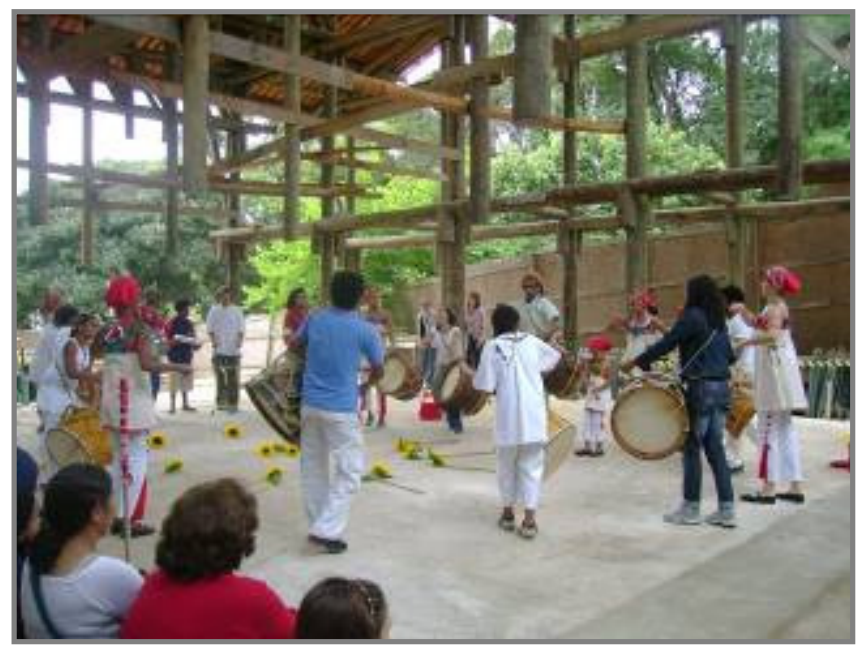

Figura 174 - Festa da Cumeeira. Fonte: arquivo pessoal, 2007.

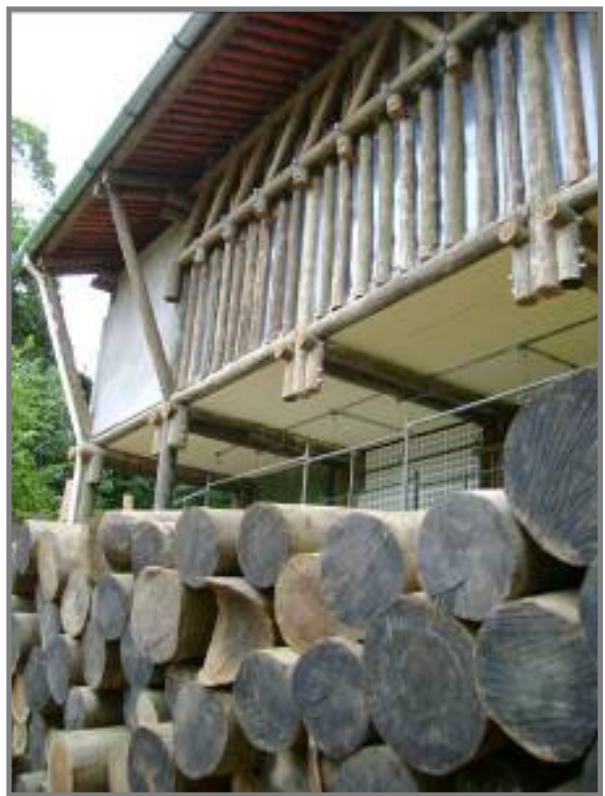

Figura 175 - A nova sede quase finalizada Fonte: arquivo pessoal, 2007 

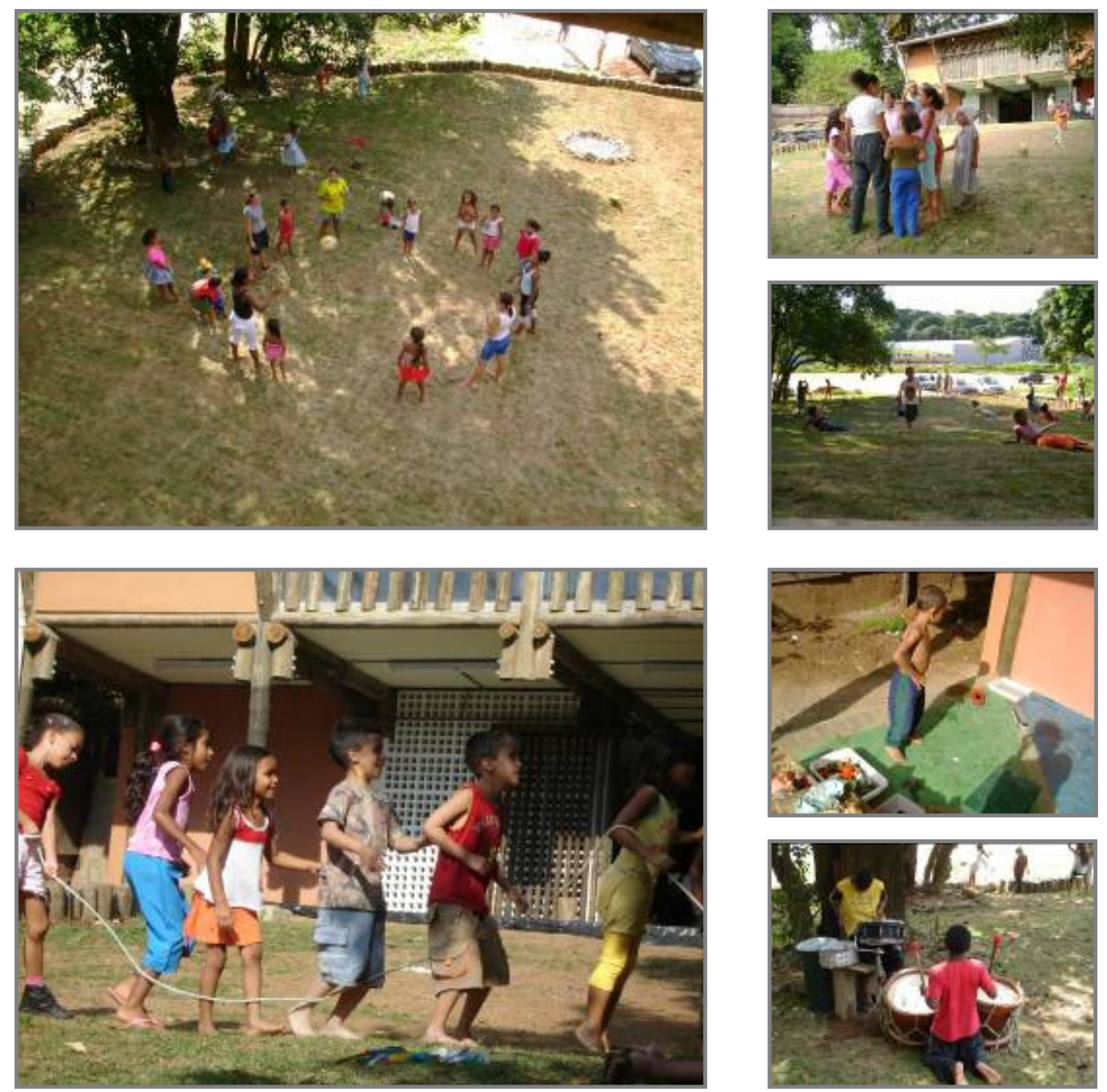

Figura 176 a 181 - 0 brincar na área externa do espaço novo. Fonte: arquivo pessoal, 2008. 


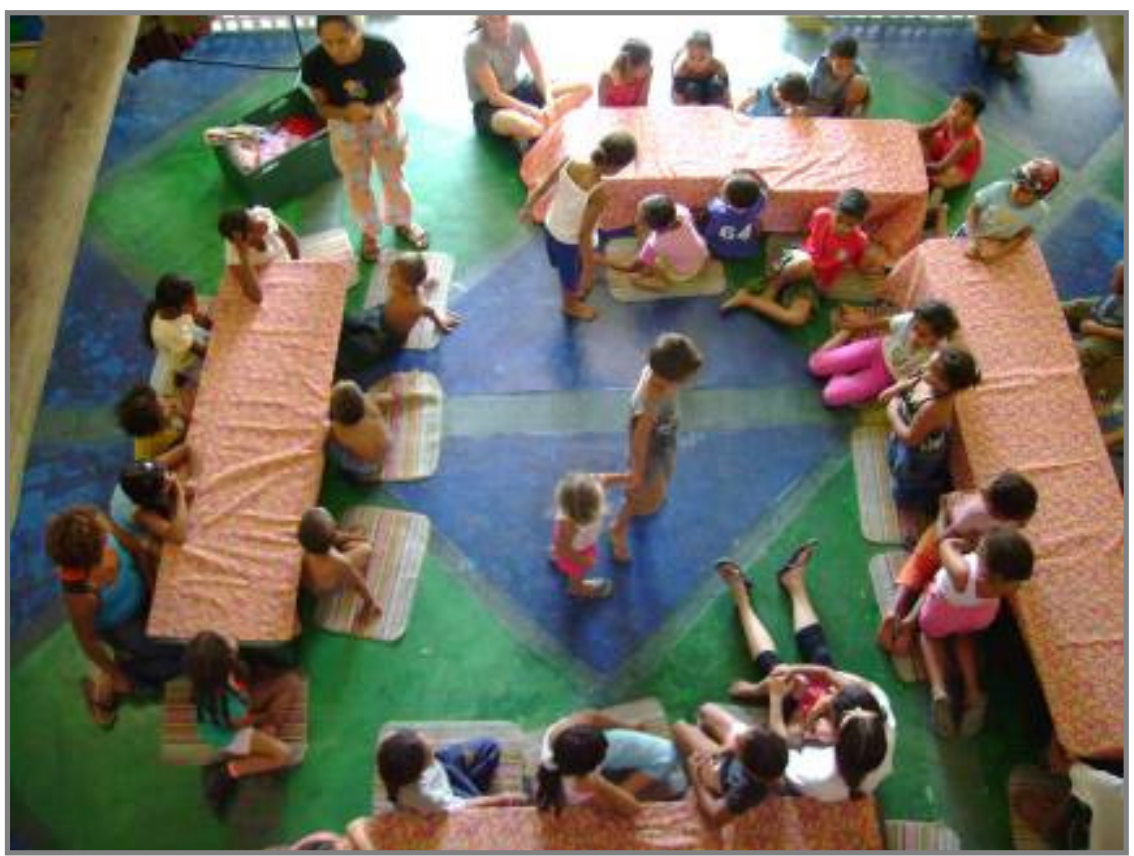

Fiqura 182 - A hora do lanche no salão multiuso. Fonte: arquivo pessoal, 2008.
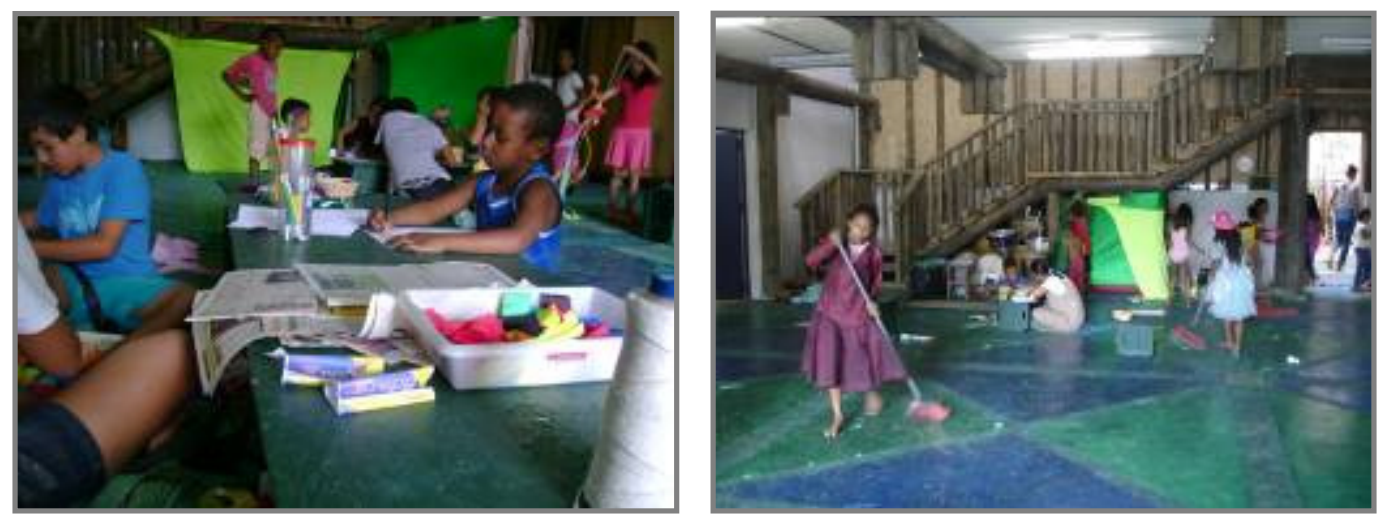

Fiqura 183 e 184 - 0 brincar no salão multiuso. Fonte: arquivo pessoal, 2008. 

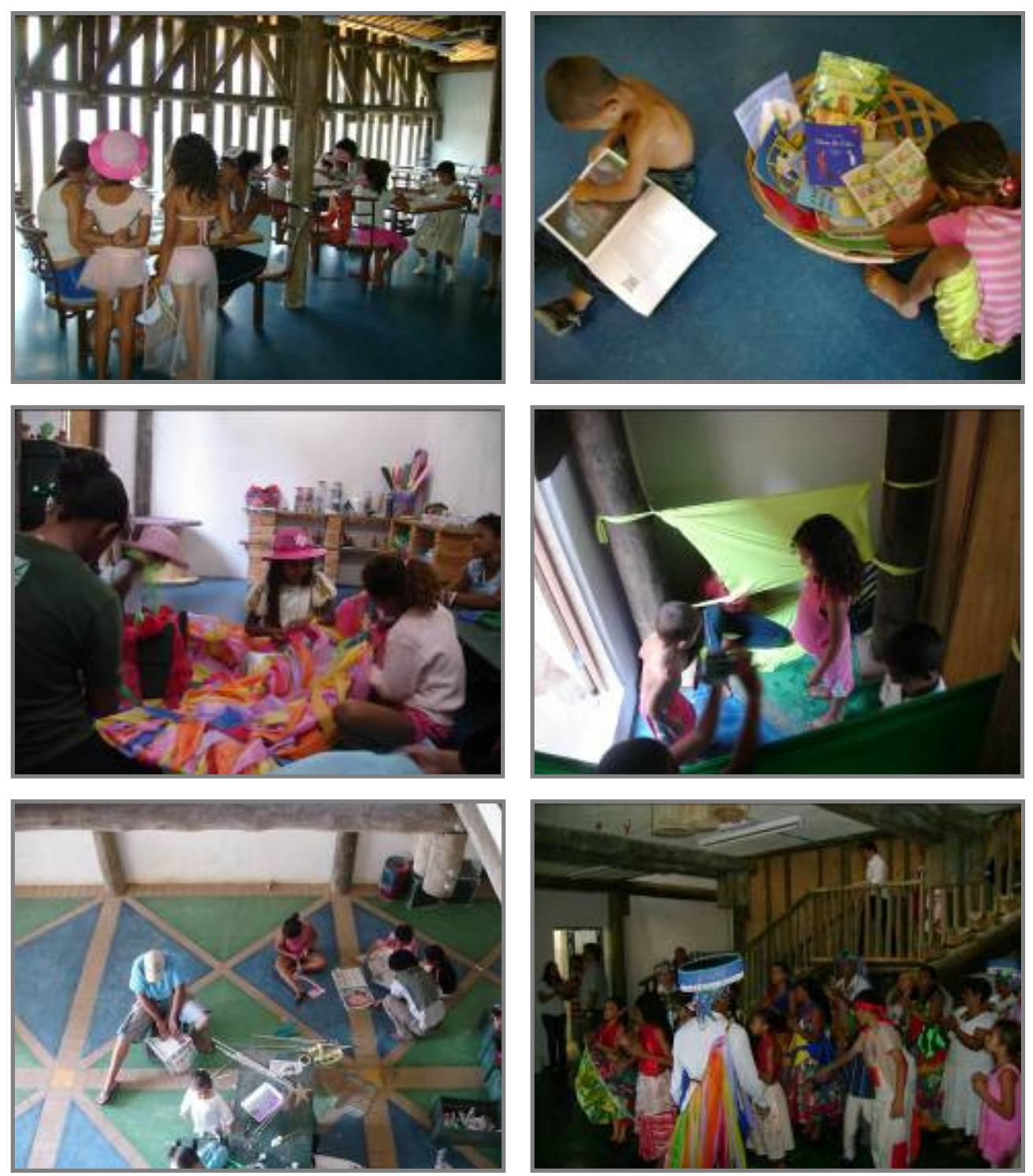

Figura 185 a 190 - 0 interior abriga diversas atividades. Fonte: arquivo pessoal, 2008. 
Novas atividades para as crianças da Aldeia

É pertinente registrar que as crianças da Aldeia de Carapicuíba ganharam outro espaço voltado para elas também em 2008, o Quilombo Ba Oba (árvore da vida). Moxé, o professor de música e mestre de capoeira seguiu caminho próprio ${ }^{55}$.

Mantém atividades para a comunidade da Aldeia como capoeira, aula de música, percussão e artesanatos. Utiliza uma área dentro do Parque, espaço que antes era um playground de uma creche, hoje desativada. Assim, propõe novo uso para um espaço antes degradado, favorecendo também a utilização da própria Aldeia.
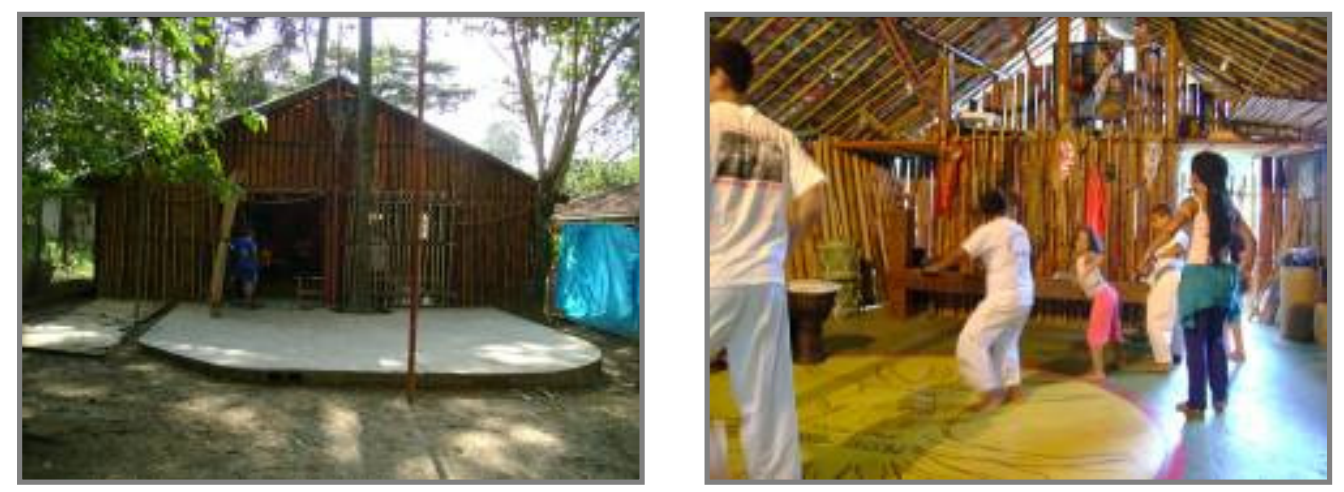

Figura 191 e 192 - A fachada e 0 interior do Quilombo Ba Oba. Fonte: arquivo pessoal, 2009. ${ }^{55}$ Moxé mantém essas atividades voltadas para comunidade da Aldeia junto com sua esposa, Mary, professora de artes e artesanias da
OCA. 


\section{CONSIDERAÇÕES FINAIS}




\section{A OCA NA ALDEIA, A ALDEIA NA OCA: RELAÇÕES E CONTRIBUIÇÕES}

A OCA nasceu a partir de um espaço livre. Esse ter nascido na aldeia possibilitou que a infância manifestasse livremente o lugar do brincar, que vivenciasse seu estágio de criança, ou seja, o seu ser criança.

A Aldeia desperta a consciência de que existe uma cultura da infância própria, e utiliza dela para formalizar os espaços da infância.

0 retorno das crianças na Aldeia - a Aldeia Parque - redefine o papel histórico como espaços arquitetônicos. Configura que a Aldeia contém 0 espaço da criança, e na sua extensão, 0 Parque também. Na realidade, entende-se que na realidade foram as crianças que conectaram a Aldeia ao Parque, com o lazer, com o brincar... 
A OCA originou-se de um processo orgânico que foi se constituindo em uma presença constante, dinâmica, tomando formas próprias. Foram sucessivos os espaços ocupados e assumidos por essa comunidade: 0 pátio da Aldeia, a Casa de Cultura, uma edificação nos arredores da Aldeia, além de um galpão no entorno. Tal ocupação consecutiva diz respeito à construção de um espaço próprio, em uma área em comodato dentro do Parque Cultural da Aldeia de Carapicuíba.

Verificou-se a partir desse reconhecimento que a atividade inicial foi agregando novos aspectos e outras faixas etárias, formando, portanto, um conjunto coeso, tanto no que diz respeito da atividade em si, quanto no que se refere à apropriação do espaço.

A Aldeia de Carapicuíba é na origem um espaço pedagógico, um núcleo, necessariamente limitado; com um propósito, uma regra, uma disciplina. Não era para crescer, se cresceu deveria se fazer outro núcleo. E, a discussão da OCA foi exatamente a mesma: é um núcleo, e, se crescer ,se faz outro. 
A vinda dessa atividade organizada para a Aldeia recupera tal origem e a atualiza. Então, há um fio condutor na questão histórica que leva até o momento atual. E, a proposta de futuro é a recuperação das manifestações comunitárias e coletivas de convívio como elemento fundamental da vida social, a qual a sociedade contemporânea está perdendo.

Nas atividades da OCA, por exemplo, consegue-se transformar um simples pedaço de papel crepom ou tecido de algodão em objetos de riqueza singular, que consumo nenhum é capaz de propor. Portanto, há um sentindo da produção comunitária e coletiva na realização da manifestação transformada em sentimento, que, por sua vez, gera uma estrutura de sensibilidade absolutamente concreta.

$E$, com isso, atinge dimensões e expressões que ocupam essa população cujos processos atuais não têm a menor condição de chegar, nem por meio dos instrumentos midiáticos que transformam todos em platéia e não em ator - uma vez que 0 ator surge como peça da máquina. Logo, a OCA representa uma atividade de resistência. 
Essa resistência se dá recuperando os processos interiores elaborados pela humanidade -, e que foram sendo colocados de lado -, e atinge níveis maiores de sociabilidade, permitindo a expressão do sujeito no contexto coletivo, sem o transformar em uma peça de engrenagem. Pois, a sugestão do mundo globalizado é transformar tudo em peça de engrenagem, uma ação extremamente empobrecedora como proposta de vida.

Pode-se concluir que a relação da Aldeia com a OCA tem sentido pedagógico histórico, mas, também, tem sentido atual, de uma pedagogia popular efetiva que vai utilizar a arquitetura e a organização dos espaços como elementos fundamentais. 


\section{CONSIDERAÇÕES FINAIS}

A presente dissertação mostra, por um lado, a possibilidade de se dar sentido novamente a um espaço fundamental, reconhecido em seu valor histórico, e que se encontrava marginalizado e desprotegido. Essa resignificação se dá pelas atividades que passam a existir no espaço, que tem relação com as atividades anteriores, mas que, ao mesmo tempo, propõem uma maneira atualizada de ser. No caso na experiência da OCA, em que deve ter nascido na Aldeia de Carapicuíba, utilizar os habitantes do entorno tem um valor universal, na medida em que ela se contrapõe à destruição de significados e valores gerados pela sociedade de consumo.

$\mathrm{Na}$ atualidade, os valores fundamentais e sagrados são transformados em relativismo profano, restando como valor da sociedade a família. E essa, longe de ser elemento retrógrado, de relações arcaicas, passa a ser a comunidade básica em que se podem recuperar os elementos fundamentais do ser, como a solidariedade e a coletividade. 0 trabalho da OCA vai exatamente resgatar as crianças, considerada o seguimento importante 
da família. Então, através delas e de suas atividades propor uma visão diversa do mundo que está aí.

0 fato de ter nascido na Aldeia de Carapicuíba não circunscreve essa experiência ou a limita, ao contrário, a atividade educacional estabelecida nesses novos modos mostra o seu vigor ao contribuir de uma forma importante para a recriação desse espaço único que pertence a todos nós e que estava desprezado. Esse vigor se estabelece exatamente na costura, já defendida pela educação libertadora, formadora da cidadania, da solidariedade.

Outro aspecto que o estudo mostra é da Aldeia enquanto patrimônio básico, fundamental, precioso que pode ser retomado, reproposto e inserido novamente no universo social e cultural.

Então, há dois elementos valorizados nesse contexto: a experiência educacional, popular, e a recuperação do espaço de valor histórico. 
Mesmo correlacionados, esses dois aspectos se apresentam como fato em si, na medida em que se fala da possibilidade de uma educação mais desejada, e na medida em que se defende a atualização e uso dos espaços históricos para sua preservação. São duas teses, mas uma não depende da outra; elas têm o valor em si.

Então, essa educação pode se desdobrar em vários aspectos, assim como a preservação da Aldeia pode absorver inúmeras outras atividades para se realizar. 


\section{BIBLIOGRAFIA}

ALMEIDA, Elvira de. Arte lúdica. São Paulo: EDUSP/ FAPESP, 1997.

ALVES, Rubens. A Escola que eu sempre sonhei sem imaginar que pudesse existir. Campinas: Papirus, 2001.

ALVES, Rubens. Conversas sobre educação. Campinas: Verus Editora, 2003.

ARNHEIM, Rudolf. Arte e Percepção Visual: Psicologia Da Visão Criadora. São Paulo: Edusp, 1979.

BACHELARD, Gaston. A poética do Espaço. São Paulo: Martins Fontes, 1999.

BARBIER, René. A pesquisa-ação. Brasília: Liber livro, 2004.

BARTHES, Roland. Mitologias. Editora Difel, 11ª edição, 2003.

BENJAMIN, Walter. Reflexões sobre a criança, o brinquedo e a educação. Trad. Marcos Vinícius Mazzari. São Paulo: Duas Cidades, 2002.

BOFF, Leonardo. Ethos Mundial, Rio de Janeiro: Vozes, 1999.

BOSI, Alfredo. Cultura Brasileira. São Paulo: Atica, 2a edição, 1991. 
BOURDIEU, Pierre. A economia das trocas simbólicas. São Paulo: Perspectiva, $5^{a}$ edição, 2004.

BROUGÈRE, Gilles. Brinquedo e cultura. São Paulo: Cortez, 1995.

CAPRA, Fritjof. As Conexões Ocultas - Ciência para uma vida Sustentável. São Paulo:Cultrix, 2002.

CASTR0, Fabíola F.M. Relação espaço-aprendizado: uma análise do ambiente préescolar. Dissertação (Mestrado), 156p. São Paulo: FAU-USP, 2000.

COHN, Clarice. Antropologia da criança. Rio de Janeiro: Jorge Zahar, 1ª edição, 2005.

COMAS, Carlos Eduardo (org). Lucio Costa e as missões: um museu em São Miguel. Porto Alegre: PROPAR/UFRGS : IPHAN/ 12aSR, 2007.

COUTINHO, Laura Maria (org). Educação da sensibilidade: encontro com a professora Maria Amélia Pereira.Brasília: Editora Universidade de Brasília, 1996.

CRUZ, Maria Cristina Meirelles Toledo. Para uma educação da sensibilidade: a experiência da Casa Redonda Centro de Estudos. Dissertação de Mestrado, Eca/ Usp, São Paulo, 2005 DUARTE, Hélio de Queiroz. Escola-classe escola-parque. São Paulo: FAUUSP, 1973. ELIADE, Mircea. 0 Sagrado e o Profano. São Paulo: Martins Fontes,1992. 
ESCALANTE, Eduardo A. A festa de Santa Cruz da aldeia de Carapicuíba no estado de São

Paulo. Rio de Janeiro: MEC-SEC: FUNARTE, Instituto Nacional do Folclore. São Paulo: Secretaria de estado da cultura, 1981.

FERNANDES, Florestan. Folclore e mudança social na cidade de São Paulo. São Paulo: Martins Fontes, 2004.

FERRAZ, Marcelo Carvalho (org.). Lina Bo Bardi. 2ed. São Paulo: Instituto Lina Bo e P. M. Bardi, 1996. 333p.

FILHO, Américo Pellegrino. Aldeia de Carapicuíba - Folclore e Mudanças: Dissertação de Mestrado. São Paulo: ECAUSP, 1979.

FREIRE, Gilberto. Casa Grande \& Senzala. Rio de Janeiro: Record, 1995.

FREIRE, Paulo. Educação na Cidade. São Paulo: Cortez, 2a edição, 1995.

FREIRE, Paulo. Pedagogia da Autonomia. São Paulo: Paz e Terra, 1ª edição, 1997.

GADAMER, Hans Georg. A atualidade do belo. Rio de Janeiro: Tempo brasieliro, 1985.

GADAMER, Hans-Georg. 0 Problema da consciência histórica. Rio de janeiro: Editora FGV, 2006.

GADOTTI, Moacir. Escola Cidadã. São Paulo: Cortez, 11ª edição, 2006. 
GUATTARI, Felix. As três ecologias. Campinas: Papirus, 16ª edição,2005.

HALL, Edwar T. A Dimensão Oculta. Francisco Alves Editora, Rio de Janeiro, 1977.

HERTZBERGER, Herman. Lições de Arquitetura. São Paulo: Martins Fontes, $2^{0}$ edição, 1999.

HOLANDA, Sergio Buarque. Raízes do Brasil. São Paulo: Companhia das Letras, 1997.

HUIZINGA, Johan. Homo Ludens. São Paulo: Perspectiva, 5ª edição, 2001.

JUNG, Carl Gustav. 0 homem e seus símbolos. Rio de Janeiro: Nova Fronteira, 2002.

KISHIMOTO, Tizuko M. Jogo, brinquedo, brincadeira e educação. São Paulo: Cortez, 2001. KISHIMOTO, Tizuko M.(org). 0 brincar e suas teorias. São Paulo: Thomson Pioneira, 2002. LANGENBUCH, Juergen Richard. A Estruturação da Grande São Paulo. Rio de Janeiro: Fundação IBGE, 1971.

LEMOS, Carlos Alberto Cerqueira. Arquitetura brasileira. São Paulo: Melhoramentos, 1979. LEONARDI, Victor. Os navegantes e o sonho. Brasília: Paralelo 15, 2005. LIMA, Mayumi W. Arquitetura e educação. São Paulo: Studio Nobel, 1995. A cidade e a criança. São Paulo: Studio Nobel, 1989.

LODY, Raul. Pernambuco popular: um toque de mestre. Recife: Relicário Produções, 2005. 
MAZZILLI, Clice T. S. Arquitetura lúdica: criança, projeto e linguagem. Tese (Doutorado) São Paulo: FAU-USP, 2003.

MEARLEAU-PONTY, Maurice. A natureza. São Paulo: Martins Fontes, 2006.

MIRANDA, Danilo Santos de (org.). 0 parque e a arquitetura: uma proposta lúdica. Campinas: Papirus, 2001.

MORI, Victor Hugo; SOUZA, Marise Campos; BASTOS, Rossano Lopes; GALLO, Haroldo. Patrimônio: Atualizando o debate. São Paulo, IPHAN, 2006.

MORIN, Edgar. Os sete saberes necessários a educação do futuro. São Paulo: Cortez, 10a edição, 2005.

NUNES, Angela. A sociedade das crianças A'uwe - Xavante. Lisboa: Instituto de Inovação Educacional, 1999.

OLIVEIRA, Claudia. 0 ambiente urbano e a formação da criança. São Paulo: Aleph, 2004. PEARCE, Joseph Chilton. 0 Fim da Evolução. São Paulo: Cultrix, 1992. PETRONE, Pasquale. Aldeamentos Paulistas. São Paulo: EDUSP, 1995.

RASMUSSEN, Steen Eiler. Arquitetura Vivenciada. Martins Fontes, São Paulo,1996. 
REIS, Nestor Goulart. Imagens de Vilas e Cidades do Brasil Colonial. São Paulo: EDUSP : Imprensa Oficial do Estado: FAPESP, 2000.

RIBEIRO, Darcy. O Povo Brasileiro. Companhia das Letras, São Paulo, 1995.

SANTOS, Milton. A Natureza do Espaço. São Paulo: EDUSP, 2004.

SANTOS, Milton. 0 espaço dividido. São Paulo: EDUSP, 2004.

SCHILLER, Friedrich. Cartas sobre a educação estética da humanidade. São Paulo: EPU, 1991.

SILVA, Luis Octavio de Faria e. Patio do colégio, o centro tradicional paulistano: Dissertação de mestrado. São Paulo: FAU-USP, 2001.

SOMMER, Robert. Espaço Pessoal. São Paulo: EDUSP, 1973.

SOUZA, Laura de Melo (org). História da vida privada no Brasil;1. São Paulo: Companhia das letras, 1997.

STADEN, Hans. Primeiros registros escritos e ilustrados sobre o Brasil e seus habitantes. São Paulo: Editora Terceiro Nome, 1999.

WEIMER, Günter. Arquitetura popular brasileira. São Paulo: Martins Fontes, 2005. 
WEISS, Luise. Brinquedos e engenhocas: atividades lúdicas com sucata. São Paulo:

Editora Scipione, 1997. 


\section{ANEXOS}




\section{ANEXOS}

\section{Compilação parcial do texto inédito de Luis Saia - 1937}

\section{Descrição da Aldeia de Carapicuíba}

[...] o caminho desce numa rampa de uns 200 metros de comprimento para entrar quase no meio do pátio, tendo à esquerda a Capela de Santa Catarina. Em frente e à direita se desenvolvem os dois lados do retângulo inteiramente preenchido com edifícios de habitação. No lado que fica à esquerda da capela só uma residência fecha 0 canto do fundo, o resto se abrindo numa larga visada pelos campos e colinas dos arredores. É possível que esta parte aldeada estivesse primitivamente tomada também por construções. Não encontrei, entretanto vestígios disso nem em ruínas, nem na tradição local. Todas as quinas do retângulo, menos a impedida, são tomadas por três das quatro estradas que servem à povoação. 0 caminho próximo ao canto fechado não existia dois anos atrás e foi aberto para servir uns sítios das vizinhanças.

Não há dúvida que a capela é a construção mais notável da aldeia, não só pelo seu tamanho ou importância que transparece através de certos detalhes construtivos, como, sobretudo pela localização dela no lado mais alto do pátio, encostada e protegida pela colina que Ihe fica atrás. Os restantes dos 19 edifícios, quando não estão ladeando a capela se dispõem em série nos lados do pátio.

A construção residencial seriada é sistemática em Carapicuíba, assim como em todas as outras aldeias jesuíticas que pude visitar. As duas casas (XIX e XX) que ladeiam a capela no seu lado esquerdo, estiveram até pouco tempo, unidas como ainda dizem lá "oitão com oitão". Em 1936 encontrei vestígios disso num compartimento de ligação, hoje desaparecido. Ficava aos fundos e parecia ser depósito ou dormitório. Ainda 
hoje, não só as peças restantes da armadura do telhado, mas também os detalhes de disposição e estrutura indicam que primitivamente uma série geminada de residências completava esta parte do retângulo.

Fronteiras à capela, as residências X, XI e XII se encontram separadas por espaços desaproveitados de 30 e 40 centímetros, o que mostra serem elas de construção bem moderna. Uma informante moradora da aldeia, dona Quirina, deu as casas X e XI como inexistentes há vinte anos, enquanto as outras da série XII, XIII, XIV, XV, XVI e XVII já eram construções antigas.

Além de mostrar que ainda há uns vinte anos a estrutura da povoação permanecia fiel ao desenho primitivo, atraindo os edifícios para o plano fundamental em torno do pátio, esses espaços desaproveitados sugerem que a construção de pau-a-pique, dessas duas casas, embora aceitando ainda uma porção de soluções procedentes da arquitetura da antiga aldeia, já se libertara, nesse tempo, do compromisso de geminação. $E$ esse costume tradicional que trouxe as residências $\mathrm{X}$ e XI para o retângulo, quando a técnica usada nelas já se desvencilhara de outros compromissos tradicionais, tudo indica tenha perdido a sua força e desaparecido há bem pouco tempo, pois somente as casas muito recentes fogem ao desenho quadrangular do pátio.

Perto da capela o terreno apresenta uma plataforma mais ou menos nivelada e mais alta do que o restante do retângulo, e em cujas bordas se plantaram dois renques de coqueiros, hoje decrépitos e caindo de velhos. No fim desta plataforma, bem no meio do pátio, montado numa base de tijolo cuja construção recente guardou a forma antiga, se ergue um cruzeiro de madeira. Permanentemente um sudário vive enrolado nos braços desta cruz.

Em volta da aldeia se estendem os terrenos que foram doados aos indígenas no primeiro século. Os mais próximos constituem "o quintal de Carapicuíba". Aí estão as roças onde os homens passam o dia quase inteiro. A moradora dona Cacilda Camargo lembra ainda o tempo em que essa parte do lugar era chamada "terreno da 
Santa". Provavelmente de Santa Catarina, padroeira da povoação. Mais para adiante dessas terras fica a "invernada", a que alguns chamam de "campos da aldeia". No quintal cada família escolhia um pedaço para plantar e pagava foros, porém a invernada era de uso coletivo e ninguém pagava nada [...]. 


\section{LEI DE PRESERVAÇÃO DA ALDEIA DE CARAPICUÍBA}

LEI N. ${ }^{\circ}$ 917, DE 11 DE SETEMBRO DE 1.986.

(Dispões sobre a preservação da Aldeia de Carapicuíba, através do disciplinamento do uso e ocupação do solo no conjunto histórico e nas áreas envoltórias).

LUIZ CARLoS alveS neVeS, Prefeito do Município de Carapicuíba, Estado de São Paulo, usando das atribuições que me são conferidas por lei,

FAÇO SABER que, a Câmara dos Vereadores de Carapicuíba, aprovou e eu sanciono e promulgo a seguinte lei:

\section{CAPÍTULOI}

\section{DISPOSICÕES PRELIMINARES}

Artigo $1^{0}$ - AS disposições desta lei aplicam-se à Aldeia de Carapicuíba, área de preservação histórica, e ao seu entorno, cujos limites se encontram assinalados na Carta e no memorial descritivo que compõem o anexo I.

Artigo $2^{0}$ - Para os efeitos desta lei, as seguintes expressões ficam assim definidas:

I - Área construída: é a soma das áreas dos pisos cobertos utilizáveis de todos os pavimentos de uma edificação;

II - Área ocupada: é a projeção, em plano horizontal, da área construída, situada acima do nível do solo;

III - Taxa de Ocupação: é o quociente entre a Área Ocupada e a Área Total do lote ou Terreno, no qual será implantado o empreendimento; Taxa de Ocupação = área ocupada Área total do lote

IV - Coeficiente de aproveitamento: é o quociente entre a área construída de uma edificação e a área total do lote ou terreno, 0 qual será implantado o empreendimento;

Coeficiente de Aproveitamento =

Área total do lote

V - Recuo: é a distância entre o limite externo da projeção horizontal da edificação e a divisa do lote; 
VI - Área de Preservação do Lote: é a área onde deverão ser mantidas as características naturais de relevo e vegetação do lote, sendo vedado qualquer tipo de impermeabilização;

VII - Taxa de Permeabilização: é o quociente entre a área de preservação do lote e sua área total, a saber:

Taxa de Permeabilização = Área de Preservação do Lote

Área Total do Lote

\section{CAPÍTULO II}

\section{DAS ZONAS DE USO}

Artigo $3^{0}$ - Ficam estabelecidas, para Aldeia de Carapicuíba e seu entorno, as seguintes zonas de uso:

I - Zona de Preservação Histórica - ZPH;

II - Zona de Urbanização Consolidada - ZUC;

III - Zona de Preservação Paisagística - ZPP.

$\S 1^{0}$ - Os perímetros das zonas de uso, estabelecidas no "caput" deste artigo, encontram-se descritos no Anexo I, sendo os limites dos imóveis tombados estão assinalados na carta que compõe o Anexo II.

$\S 2^{0}$ - As zona de uso a que se refere os Anexos I e II, estão delimitadas me cartas do Sistema Cartográfico Metropolitano - SCM, em escalas de 1:10.000 e de 1:2.000, respectivamente, as quais serão utilizadas, obrigatoriamente, para 0 efeito de cumprimento desta lei.

Artigo $4^{0}$ - Por ocasião da análise de projetos referentes à instalação de empreendimentos na área disciplinada por esta lei, a Administração Municipal deverá observar as seguintes normas e características de cada zona de uso:

$\S 1^{0}$ - Zona de Preservação Histórica - ZPH

I - Nos imóveis tombados pela Secretaria do Patrimônio Histórico e Artístico e Nacional - SPHAN ou Conselho de Defesa do Patrimônio Histórico, Arqueológico, Artístico e Turístico do Estado de São Paulo - CONDEPHAAT:

a - Fica vedado o desdobro de lotes, bem como a construção de novas edificações ou acréscimos às existentes;

b - Fica permitido o comércio de porte local, desde que as características arquitetônicas dos imóveis não sejam alteradas, interna ou externamente. 
II - Nos imóveis que não se enquadram nas disposições do item I:

a - Ficam permitidos os usos residencial, comercial, de serviços e institucional;

b - Deverão ser observados os parâmetros de implantação, referentes ao lote mínimo, frente mínima, recuos/frontal e lateral, taxa de ocupação e taxa de permeabilização, constantes do Anexo III, quadro 2;

c - Fica vedada a edificação de imóvel com mais de um pavimento.

$\S 2^{0}$ - Zona de Urbanização Consolidada - ZUC, composta de quatro área contínuas: A, B, C, e D.

a - Deve-se evitar a ocupação intensiva dos lotes e incentivar os usos comercial, de serviços e institucional, de apoio ao uso residencial.

$\S 3^{\circ}$ - Zona de Preservação Paisagística - ZPP

a - Deve-se manter ocupação esparsa, de baixa densidade, comportando usos residencial, institucional, especial e de serviços, voltados ao lazer e turismo.

Artigo $5^{\mathbf{0}}$ - Nas zonas, referidas no artigo $4^{0}$, ficam estabelecidos os usos residenciais, de serviços, comercial, institucional e especial, bem como os índices urbanísticos e os parâmetros de implantação, escritos no anexo III, quadros 1, 2 e 3.

Artigo $\mathbf{6}^{\mathbf{0}}$ - Nenhuma obra, a ser realizada na Zona de Preservação Histórica, bem como no seu entorno, poderá ser autorizada pelo Município sem a prévia aprovação do respectivo projeto pela SPHAN e CONDEPHAAT, observadas, neste caso, as legislações federais e estaduais pertinentes.

Parágrafo único - Para os efeitos desta lei, entende-se por obra qualquer trabalho de engenharia, de que resulte criação, modificação ou reparação de imóvel edificado, mediante construção, ou que tenha como resultado qualquer transformação do meio ambiente natural ou histórico, incluído, para esses fins, a realização de aterros e serviços de terraplenagem e o loteamento do solo urbano.

\section{CAPÍTULO III}

\section{DA APROVACÃO, DO REGISTRO E DO LICENCIAMENTO}

Artigo $7^{0}$ - Os empreendimentos a serem executados nas zonas estabelecidas pelo artigo $4^{0}$ serão, por ocasião dos exames dos respectivos pedidos de licença ou da realização de registros municipais de qualquer espécie, enquadrados em uma das categorias de uso, constantes do anexo III. 
$\S 1^{\circ}$ - Os projetos de edificações e pedidos de registro e de licença, destinados a usos não especificados nesta lei, deverão ser analisados comparativamente aos demais usos permitidos.

$\S 2^{0}$ - A análise comparativa, de que trata o parágrafo $1^{\circ}$ será realizada pela Comissão Especial de Análise, mencionada no artigo 11, sendo que a expedição de licença pela Secretaria de Planejamento Urbano fica condicionada à emissão de parecer favorável da referida Comissão.

Artigo $\mathbf{8}^{\mathbf{0}}$ - Na execução dos empreendimentos e no desenvolvimento das atividades, bem como no exame dos respectivos projetos, para fins de licenciamento, deverão ser observadas as restrições quanto à ocupação do solo, constantes do Anexo III desta lei.

Artigo $9^{\circ}$ - Para a instalação de qualquer empreendimento nos imóveis tombados, seus proprietários ou usuários dependem, além da licença da Administração Municipal, da prévia autorização do SPHAN e do CONDEPHAAT, no que diz respeito às normas relativas a reformas, restaurações, comunicação visual, anúncios publicitários e sinalização.

Parágrafo único - Independe de prévia autorização do SPHAN e do CONDEPHAAT a identificação numérica dos imóveis tombados, que deverá ser realizada mediante a fixação de plaquetas esmaltadas na fachada do imóvel, ficando proibida a utilização de qualquer outra forma de numeração.

Artigo $10^{\circ}$ - Caberá à Secretaria dos Negócios Metropolitanos, sem prejuízo dos demais órgãos e entidades federais e estaduais, o exame e a anuência prévia para aprovação, pelo Município, de loteamento e desmembramento localizados na área de preservação histórica e no seu entorno, cujos limites se encontram assinalados no Anexo I.

\section{CAPÍTULO IV}

\section{DA COMISSÃO ESPECIAL DE ANÁLISE}

Artigo $11^{0}$ - Fica criada a Comissão Especial de Análise, como órgão consultivo e deliberativo, junto a Secretaria do Planejamento Urbano, com a finalidade, entre outras, de proceder à análise de projetos de edificações e pedidos de registro e de licença destinados a usos não especificados nesta lei.

$\S 1^{0}$ - A comissão se constituirá de: 
I - Um representante da Secretaria de Planejamento Urbano;

II - De um representante da Secretaria dos Negócios Jurídicos;

III - De um representante da Secretaria de Educação, cultura, Esportes, Recreação e Turismo;

IV - De um representante da Câmara Municipal;

V - De dois representantes da Aldeia de Carapicuíba.

$\S 2^{0}$ - A Comissão, prevista neste artigo será regulamentada pelo Executivo Municipal.

\section{CAPÍTULO V}

DA FISCALIZAÇ̃̃OO E DAS PENALIDADES

Artigo $\mathbf{1 2}^{\circ}$ - A fiscalização das disposições da presente lei e demais normas complementares será exercida por fiscais credenciados da Prefeitura, aos quais ficam asseguradas a entrada, a qualquer dia e hora e a permanência, pelo tempo que se tornar necessário, em imóveis públicos e privados, observada a legislação vigente.

Parágrafo único - 0s fiscais, quando obstados, poderão requisitar força policial para o exercício de suas atribuições.

Artigo $13^{\circ}$ - Compete aos fiscais credenciados:

I - Efetuar vistorias em geral, levantamentos e inspeções;

II - Verificar a ocorrência de infrações;

III - Lavrar, de imediato, autos de inspeção e, quando for o caso, de infração, fornecendo cópia ao interessado;

IV - Intimar, por escrito, quaisquer pessoas físicas ou jurídicas, para prestarem esclarecimentos e exibirem documentos pertinentes, em local em data previamente fixadas.

Artigo $14^{0}$ - Os relatórios dos resultados da fiscalização serão remetidos ao órgão competente, para anotações nos registros municipais de informações.

Artigo $15^{0}$ - Pelo descumprimento das disposições previstas nesta lei e sem prejuízo de outras estabelecidas em leis especiais, serão aplicadas as seguintes sanções:

I - Advertência, com prazo de 10 dias para regularização da situação, nos casos de primeira infração, quando não haja motivo relevante que justifique a imediata aplicação das penalidades de multa, interdição, embargo ou demolição. 
II - Multa diária de 10 a 100 0TNs, em caso de não cumprimento da regularização no prazo fixado pela Administração;

III - Interdição de atividades, temporária ou definitiva, para os casos de infração continuada;

IV - Embargo ou demolição, total ou parcial, de construção executada sem aprovação ou em desacordo com os projetos aprovados, representando o infrator pelos danos e despesas a que der causa, direta ou indiretamente.

Parágrafo único - As penalidades de interdição, embargo ou demolição serão aplicadas sem prejuízo daqueles objeto dos inciso I e II deste artigo.

\section{CAPÍTULO VI}

DAS DISPOSIÇÕES GERAIS

Artigo $16^{\circ}$ - 0 sistema viário dos loteamentos a serem implantados na ZPP, deverá obedecer às características das vias de circulação constantes do quadro de Vias de Circulação, integrante da Lei Municipal $n^{0} 714$, de 25 de Abril de 1.984, ficando vedada a abertura de vias do tipo expressa, arterial e principal.

Artigo $17^{\circ}$ - Ao longo das águas correntes e dormentes será obrigatória a reserva de uma faixa "no aedificandi", de 15 (quinze) metros de cada lado, com exceção dos locais onde as várzeas desses cursos d'água se estenderem além desse limite, ou em terrenos alagadiços ou sujeitos a inundações, salvo maiores exigências da lei específica.

Artigo $18^{\circ}$ - A implantação de equipamentos ou tipos de uso compatíveis com as características físicas das várzeas ou faixas ribeirinhas, que acomodem enchentes periódicas, tais como áreas verdes, obra de infra-estrutura sanitária, parques, campos esportivos, área de feiras e circos, exposições, agricultura e sistema viário, poderão ser autorizadas pelo Município.

Artigo $\mathbf{1 9}^{\circ}$ - Por ocasião da execução de obras de construção e de reforma, deverá ser preservada a arborização existente, sendo obrigatória a apresentação gráfica da exata localização dos elementos arbóreos do lote, com a respectiva discriminação, vulgar e científica, de cada espécie.

$\S 1^{0}$ - A remoção da arborização existente só será autorizada mediante aprovação do Município, ficando obrigado o responsável pelo projeto, a repor os elementos arbóreos removidos guardando a diversidade biológica das espécies.

$\S 2^{0}$ - A preservação da arborização de que trata este artigo, deverá ser realizada pelo proprietário ou usuário do lote, independentemente de execução de obras de construção ou reforma. 
Artigo $20^{\circ}$ - As urbanizações, construções e atividades, comprovadamente existentes ou exercidas anteriormente à data da publicação desta lei, nos termos das normas e regulamentos vigentes, deverão, a critério da Comissão Especial de Análise, adequar-se às suas disposições, ressalvado o direito adquirido, 0 ato jurídico perfeito e a coisa julgada.

Parágrafo único - Na impossibilidade do cumprimento das adaptações eventualmente exigidas, as urbanizações, construções e atividades, referidas no "caput " deste artigo, poderão, caso haja oportunidade ou conveniência, ser suprimidas, total ou parcialmente, mediante indenização ou desapropriação.

Artigo $21^{0}$ - Além das disposições desta lei, aplicam-se à Aldeia de Carapicuíba, área de preservação histórica, e ao seu entorno, cujos limites se encontram assinalados no Anexo I, a legislação federal e estadual sobre tombamento, bem como as normas e regulamentos expedidos pela Secretaria de Patrimônio Histórico e Artístico Nacional - SPHAN e do Conselho de Defesa do Patrimônio Histórico, Arqueológico, Artístico e Turístico do Estado de São Paulo - CONDEPHAAT.

Artigo $2^{\circ}$ - Para execução do disposto nesta lei, o Poder Executivo poderá celebrar convênios com órgãos e entidades federais e estaduais, além da comunidade envolvida, visando, dentre outros objetivos, a fiscalização, aprovação de projetos e cumprimento das obrigações fixadas nesta lei.

Artigo $\mathbf{2 3}^{\circ}$ - 0 poder executivo regulamentará, no prazo de 30 dias, 0 artigo 11 desta lei.

Artigo $24^{\circ}$ - As demais disposições desta lei poderão ser regulamentadas pelo Executivo, caso julgue necessário.

Artigo $\mathbf{2 5}^{\circ}$ - Esta lei entrará em vigor na data de sua publicação, revogadas as disposições em contrário.

Prefeitura do Município de Carapicuíba, 26 de Junho de 1.987.

LUIZ CARLOS ALVES NEVES

PREFEITO MUNICIPAL

Registrado no livro próprio na Secretaria dos Negócios Jurídicos, nesta data.

MARIA ANGÉLICA SALDANHA ARIENTE

SECRETÁRIO DOS NEGÓCIOS JURÍDICOS 


\section{DOCUMENTOS RELATIVOS AO TOMBAMENTO}

\begin{tabular}{ll} 
Detalhes de Sítios Arqueológicos & \\
Município - UF & Carapicuíba - SP \\
Descrição sumária & Aldeamento jesuítico do século XVI, XVII e reocupada no século XVIII. \\
Comprimento & $100 \mathrm{~m}$ \\
Largura & $\mathbf{8 0 ~} \mathrm{m}$ \\
Altura Máxima & $\mathbf{7 m}$ \\
Àrea & $\mathbf{8 0 0 0} \mathrm{m}^{2}$ \\
Medição & Mapa; \\
Nome e sigla do documento cartográfico & Fotografia aérea EMPLASA / AFA \\
Ano de edição & 1994 \\
Escala & $1: 25.000$ \\
Unidade Geomorfologica & Planalto \\
Compartimento Topográfico & Meia encosta \\
Altitude & 763 \\
Água Próxima & Lago (recente) \\
Distância & 70 \\
Rio & Carapicuíba \\
Bacia & Tietê \\
Vegetação & sem vegetação na aldeia e entornos algumas árvores \\
Uso atual da terra & meio urbano; via publica; \\
Propriedade da terra & terra pública; \\
Tombamento & estadual; federal; UNESCO; \\
Categoria & Unicomponencial \\
Tipo & Histórico \\
Forma & Redução jesuítica \\
& \\
\hline
\end{tabular}


Tipo de Solo

Estratigrafia

Contexto Deposição

Exposição

Estruturas

Artefatos

Acervo

Arte Rupestre

Filiação Cultural

Grau de integridade

Fatores Destruição

Outros fatores antrópicos

Possibilidades Destruição

Medidas Preservação

Relevância do sítio

Atividades desenvolvidas no local

Nome do Responsável

Nome Projeto

Nome Instituição

Endereço Instituição

UF da Instituição

CEP da Instituição

E-Mail da Instituição

Telefone/Fax da Instituição
Argiloso

Nenhuma sondagem foi realizada para verificação de estatigrafia

em profundidade

céu aberto

vestígios de edificação;

cerâmico;

Fundação Cultural de Jacarey / SP

Ausente;

entre 25 e $75 \%$

Erosão pluvial; Construção de estradas; >Construção de moradias;

Reestruturação do centro alterou a antiga paisagem de implantação da aldeia. 0 avanço da conturbação entre Cotia e Carapicuíba fez com que grandes porções de terra fossem removidos e usados como aterro em outras áreas dos municípios em questão.

0 aumento das atividades de implantação do parque já avança em direção a algumas construções do século XIX.

Projeto de proteção do patrimôinio e musealização da aldeia com incentivo de atividade turística de perfil cultural

alta

Registro; Coleta de superfície;

Erika Marion Robrahn González

Programa de Pesquisa e Resgate do Patrimônio Arqueológico e Histórico RODOANEL - Trecho Oeste

Documento Arqueologia SC Ltda.

Av. Dona Cherubina Viana 150 - Granja Viana

SP

06708-360

arqueo@terra.com.br

(11) $4702-2088$ / 4702-3011 
Bibliografia1

Bibliografia2

Responsável Preenchimento

Data Preenchimento

Localização Dados
ROBRAHN-GONZÁLEZ, E.M. \& ZANETTINI, P.E. - 2002 - Dimensionamento e Valoração Científica do Patrimônio Arqueológico e Histórico do RODOANEL, Trecho Oeste. DERSA / DOCUMENTO Antr. e Arqueologia, Relatório interno com exemplar para a 9a SR/IPHAN.

ROBRAHN-GONZÁLEZ, E.M. \& ZANETTINI, P.E. - 2003 - Programa de Pesquisa e Resgate do Patrimônio Arqueológico, Histórico e Cultural, do RODOANEL - Trecho Oeste - Vol.: 1, 2, 3 e 4 Relatório Final, entregue ao IPHAN/DEPAM, 9a SR/IPHAN e DERSA, em 2003.

\section{Erika Marion Robrahn González}

$10 / 01 / 2002$

Documento Arqueologia SC Ltda. 
Aldeia de Carapicuíba, SP: conjunto arquitetônico e urbanístico (Carapicuíba, SP)

Descrição:Aldeamento jesuíta instalado numa sesmaria de 1580. A importância deste conjunto está na permanência de sua primitiva feição urbanístico-arquitetônica. Todavia, é também representativo da precariedade dessas instalações em território paulista, quando comparado às grandes missões do Sul. As unidades de residência, no entanto, receberam mudanças em seu sistema construtivo. Tombado em 1940, 0 conjunto recebeu intervenções para a sua consolidação em 1954, 1956 e em 1960/61.

Endereço: - Carapicuíba - SP

Livro Arqueológico, Etnográfico e Paisagístico

Inscrição:007

Data:13-5-1940

No Processo:0218-T-39

Capela de São João Batista (Carapicuíba, SP)

Descrição:Capela missioneira em taipa de pilão e telhado em duas águas com madeiramento aparente. Foi reconstruída em 1736, substituindo a capela jesuítica original. Altar-mor de gosto popular e terça decorada na sacristia demonstram a mão indigena na sua construção.

Endereço: - Carapicuíba - SP

Livro Histórico

Inscrição:151

Data:25-1-1941

Livro de Belas Artes

Inscrição:293

Data:25-1-1941

\section{No Processo:0221-T-39}

Observações:0 tombamento inclui todo o seu acervo, de acordo com a Resolução do Conselho Consultivo da SPHAN, de 13/08/85, referente ao Processo Administrativo $n^{0} 13 / 85 /$ SPHAN. 


\section{CURSO A ARTE DO BRINCANTE PARA EDUCADORES}

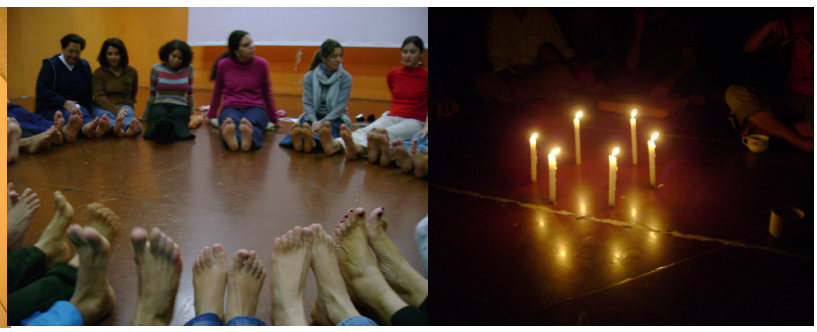


"Pressinto que os homens estão ficando muito duros e o mundo muito triste. A arte e os artistas populares me mostraram que a despeito desses dias de tanta agonia, ainda se pode esperançar um mundo mais justo, onde não se avilte a beleza e onde as crianças não sejam obrigadas a mendigarem o reino dos céus.

De minha parte espero permanecer fiel a esse ensinamento profundo. E se em algum momento dessa bandeira eu for capaz de refletir o espírito ou caráter do povo que somos, me sentirei mais do que revigorado para prosseguir nessa estrada de pó, sonho e enigma que me regressa ao Divino do meu povo".

ANTÔNIO NÓBREGA 


\section{CURSO DE EDUCADOR BRINCANTE}

\section{Teatro Escola Brincante}

0 Teatro Escola Brincante foi criado em 1992, por dois artistas amantes da cultura popular brasileira, Antonio Nóbrega e Rosane Almeida.

0 espaço, uma antiga fábrica de lustres na Vila Madalena, escolhido apenas para guardar os apetrechos dos espetáculos, criar danças e animar folias, logo se transforma em teatro. E os espectadores saiam animados e contagiados pela alegria das apresentações assim surgiu a vocação como escola também.

Cria o curso para educadores com formato inédito, além de promover oficinas e encontros que abordam percussão e danças brasileiras, variadas manifestações populares, poesia popular, contos tradicionais e confecção de máscaras, figuras e adereços. 
Em 2005 se transforma em instituto e se fortalece como centro de referência da cultura popular brasileira com

[...] ações de conhecimento, valorização, aprofundamento e recriação das inúmeras manifestações artísticas do país, todas elas relacionadas de maneira vital com as práticas culturais das suas comunidades, revelando assim a maravilhosa riqueza da cultura nacional e a importância da celebração da diversidade para construção de uma identidade cultural brasileira [...] TEATRO BRINCANTE, 2007.

E também é reconhecido como Ponto de Cultura, um programa do Ministério da Cultura que incentiva locais como agente cultural que articula e impulsiona um conjunto de ações em suas comunidades. 


\section{CURSO E ATIVIDADES}

0 curso A Arte do Brincante para Educadores tem como estrutura difundir a importância da arte brasileira na formação das crianças e adolescentes. É dividido em 8 módulos, com carga horária de 128 horas e oferece 0 estudo e a prática de cantos, danças, toques instrumentais, histórias, brinquedos e brincadeiras. Aspectos que alimenta a cultura popular e possibilita a reflexão sobre o Brasil. 
0 Programa

1- Folguedos populares brasileiros

Prática das formas de dança presentes nos Folguedos populares brasileiros, bem como estudo e reflexão sobre a sua função na educação brasileira.

Coordenação: Rosane Almeida

Programação:

1. Os brincantes e o Folguedos Popular

2. A trajetória dos folguedos populares.

3. A memória e 0 corpo.

4. 0 corpo da natureza e a natureza do corpo

2- Iniciação à cultura da criança

Reflexão sobre as múltiplas dimensões da cultura infantil buscando uma compreensão mais ampla e sensível do universo da criança a partir de uma experiência renovada do brincar.

Coordenação: Lydia Hortélio

Programação:

1. Cultura infantil na arte dos povos

2. Música tradicional da infância. Repertório de cantigas.

3. 0 objeto brinquedo

4. Natureza: a casa da criança 


\section{3- Por uma educação da sensibilidade}

Abordagem do processo de desenvolvimento da criança, a partir de relatos e de imagens da cultura infantil, compreendendo o brincar como 0 ato do conhecimento sensível, iniciador do processo criador humano.

Coordenação: Maria Amélia Pereira (Péo)

Programação:

1. Singularidade e universalidade do brincar.

2. Relação do homem com a natureza e a cultura no ato do brincar.

3. 0 tempo cíclico e sua relação com o tempo da infância

4. 0 conceito de aprendizagem compreendido como a aventura da consciência

\section{4- Figuras e adereços dos folguedos populares}

Confecção, utilização e manipulação de figuras, (míticas e típicas) presentes no teatro, na dança e nos folguedos da tradição popular brasileira.

Coordenação: Cristina Cruz e Maria do Carmo Lima

Programação:

1. As figuras do imaginário popular brasileira

2. Os tipos e arquétipos

3. Adereços (natalinos, juninos e carnavalescos) 
$\underline{\text { 5- Contos e histórias tradicionais. }}$

Estudo e exercício das diferentes formas de contar da tradição oral, vistos como instrumento da educação.

Coordenação: Cristiane Velasco

Programação:

1. Ouvir histórias

2. Relatos orais e visuais sobre a experiência de co

3. Iniciação à prática de contar histórias

6- Música das manifestações populares da cultura brasileira

Iniciação ao universo dos toques, instrumentos e cantos da música brasileira.

Coordenação: Eugênia Nóbrega

Programação:

1. A gaita dos cabocolinhos

2. Loas, toadas e cantigas

3. 0 batuque do Pandeiro, o balanço do Ganzá, o toque da Caixa e o baque da Alfaia.

\section{7- A Palavra Poética}

Introdução à poética popular brasileira através da prática e estudo de suas formas e gêneros. Coordenação: Lucilene Silva e Convidados

Programação: 
1. Roda de versos

2. A arte da cantoria (por Antonio Nóbrega )

3. Romanceiro e tradição oral

4. Literatura de Cordel

\section{8 - Construção de brinquedos}

Construção de brinquedos presentes na cultura tradicional infantil brasileira a partir do estudo da riqueza de suas formas e mecanismos.

Coordenação: Adelson Murta

Programação:

1. Brinquedos com o corpo.

2. Brinquedos com a natureza

3. Brinquedos com materiais recicláveis

4. Brinquedos sonoros 

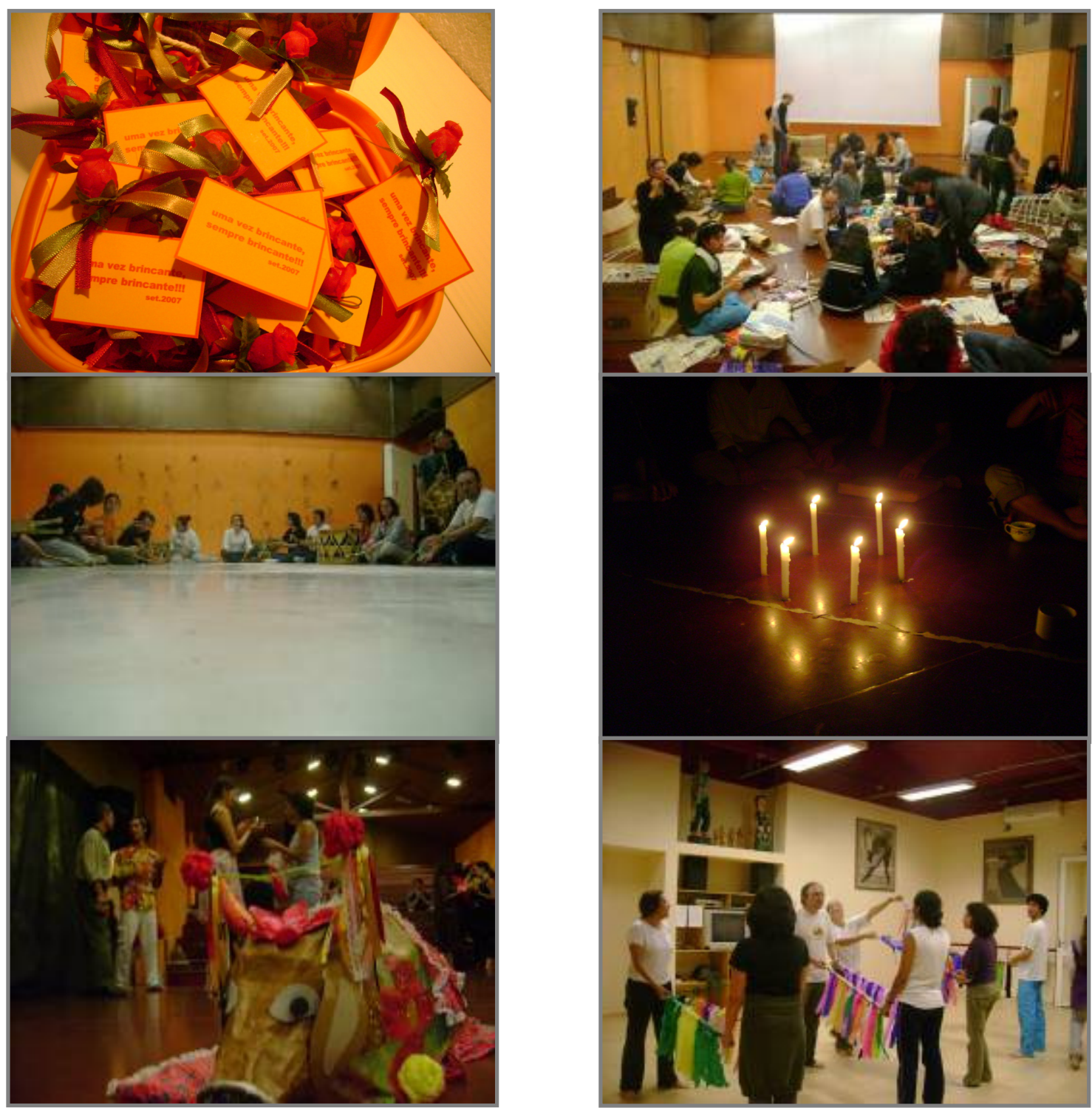

Figuras de 1a 6 - Atividades do Curso Educador Brincante. Fonte: arquivo pessoal, 2007. 

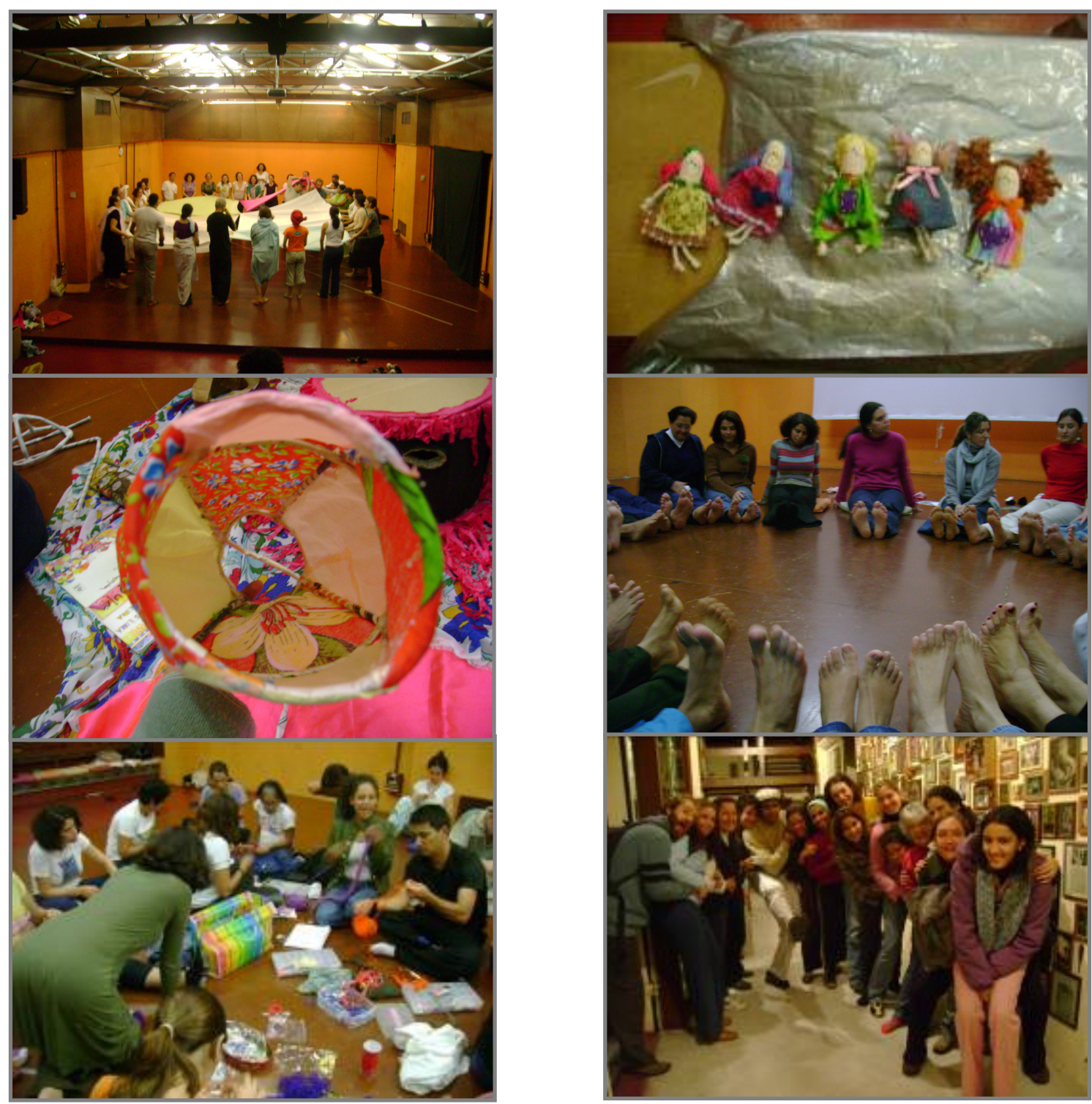

Figuras de 1a 6 - Atividades do Curso Educador Brincante. Fonte: arquivo pessoal, 2007. 
